\title{
Climatic Atlas of the Delaware River Basin
}

U.S. GEOLOGICAL SURVEY PROFESSIONAL PAPER 1392 


\section{AVAILABILITY OF BOOKS AND MAPS OF THE U.S. GEOLOGICAL SURVEY}

Instructions on ordering publications of the U.S. Geological Survey, along with the last offerings, are given in the current-year issues of the monthly catalog "New Publications of the U.S. Geological Survey." Prices of available U.S. Geological Survey publications released prior to the current year are listed in the most recent annual "Price and Availability List." Publications that are listed in various U.S. Geological Survey catalogs (see back inside cover) but not listed in the most recent annual "Price and Availability List" are no longer available.

Prices of reports released to the open files are given in the listing "U.S. Geological Survey Open-File Reports," updated monthly, which is for sale in microfiche from the U.S. Geological Survey, Books and Open-File Reports Section, Federal Center, Box 25425, Denver, CO 80225. Reports released through the NTIS may be obtained by writing to the National Technical Information Service, U.S. Department of Commerce, Springfield, VA 22161; please include NTIS report number with inquiry.

Order U.S. Geological Survey publications by mail or over the counter from the offices given below.

\section{BY MAIL}

\section{Books}

Professional Papers, Bulletins, Water-Supply Papers, Techniques of Water-Resources Investigations, Circulars, publications of general interest (such as leaflets, pamphlets, booklets), single copies of periodicals (Earthquakes \& Volcanoes, Preliminary Determination of Epicenters), and some miscellaneous reports, including some of the foregoing series that have gone out of print at the Superintendent of Documents, are obtainable by mail from

U.S. Geological Survey, Books and Open-File Reports Section Federal Center, Box 25425 Denver, CO 80225

Subscriptions to periodicals (Earthquakes \& Volcanoes and Preliminary Determination of Epicenters) can be obtained ONLY from

\section{Superintendent of Documents \\ U.S. Government Printing Office \\ Washington, DC 20402}

(Check or money order must be payable to Superintendent of Documents.)

\section{Maps}

For maps, address mail orders to

\section{U.S. Geological Survey, Map Distribution Federal Center, Box 25286 \\ Denver, CO 80225}

Residents of Alaska may order maps from

U.S. Geological Survey, Map Distribution New Federal Building - Box 12

101 Twelfth Ave., Fairbanks, AK 99701

\section{OVER THE COUNTER}

\section{Books}

Books of the U.S. Geological Survey are available over the counter at the following U.S. Geological Survey offices, all of which are authorized agents of the Superintendent of Documents:

- ANCHORAGE, Alaska-4230 University Dr., Rm. 101

- ANCHORAGE, Alaska-605 West 4th Ave., Rm. G-84

- DENVER, Colorado-Federal Bldg., Rm. 169, 1961 Stout St.

- LOS ANGELES, California-Federal Bldg., Rm. 7638, 300 North Los Angeles St.

- MENLO PARK, California-Bldg. 3, Rm. 3128, 345 Middlefield Rd.

- RESTON, Virginia-National Center, Rm. 1C402, 12201 Sunrise Valley Dr.

- SALT LAKE CITY, Utah-Federal Bldg., Rm. 8105, 125 South State St.

- SAN FRANCISCO, California-Customhouse, Rm. 504, 555 Battery St.

- SPOKANE, Washington-U.S. Courthouse, Rm. 678, West 920 Riverside Ave.

- WASHINGTON, DC-U.S. Department of the Interior Bldg., Rm. 2650, 1849 C St., NW.

\section{Maps}

Maps may be purchased over the counter at the U.S. Geological Survey offices where books are sold (all addresses in above list) and at the following U.S. Geological Survey offices:

- ROLLA, Missouri-1400 Independence Rd.

- FAIRBANKS, Alaska-New Federal Bldg., 101 Twelfth Ave. 


\section{Climatic Atlas of the Delaware River Basin}

By CAROL B. JENNER and HARRY F. LINS

U.S. GEOLOGICAL SURVEY PROFESSIONAL PAPER 1392

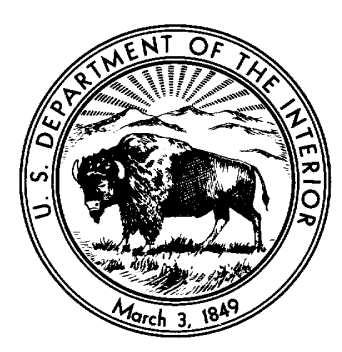

UNITED STATES GOVERNMENT PRINTING OFFICE, WASHINGTON：1991 


\section{U.S. DEPARTMENT OF THE INTERIOR}

MANUEL LUJAN, Jr., Secretary

\section{U.S. GEOLOGICAL SURVEY}

Dallas L. Peck, Director

Any use of trade, product, or firm names in this publication is for descriptive purposes only and does not imply endorsement by the U.S. Government

\footnotetext{
Library of Congress Cataloging in Publication Data

Jenner, Carol B.

Climatic atlas of the Delaware River Basin.

(Geological Survey professional paper ; 1392) Covers the period 1950-1979.

Bibliography: $p$.

Supt. of Docs. no.: I 19.16:1392

1. Delaware River Watershed (N.Y.-Del. and N.J.)-Climate-Maps. I. Lins, Harry F. II. Title. III. Series. G1247.D44C8J4 $1991 \quad 912$ '.155169749 85-600149
}

For sale by the Books and Open-File Reports Section, U.S. Geological Survey,

Federal Center, Box 25425, Denver, CO 80225 


\section{CONTENTS}

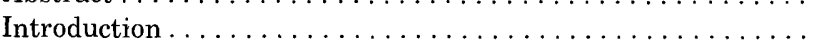

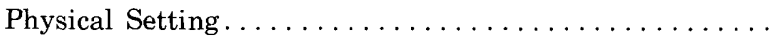

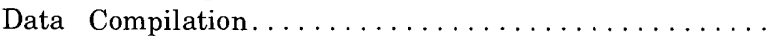

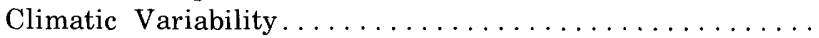

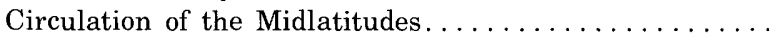

Relation of Upper Air Flow to Surface Weather........ Atmospheric Circulation and Climatic Variability.......

Climatic Characteristics of the Delaware River Basin.......

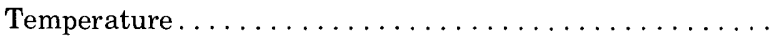
Average Annual Temperature.................

Average December Temperature............... 14

Average January Temperature.............. 16

Average February Temperature.............. 18

Average March Temperature.............. 20

Average April Temperature................ 22

Average May Temperature.................. 24

Average June Temperature. . . . . . . . . . . . . 26

Average July Temperature................ 28

Average August Temperature.............. 30

Average September Temperature. . . . . . . . . . . 32

Average October Temperature.............. 34

Average November Temperature............ 36

Average Winter Temperature.............. 38

Average Spring Temperature.............. 40

Average Summer Temperature............... 42

Average Fall Temperature................. 44

Temperature Extremes.................... 46

Heating Degree Days. . . . . . . . . . . . . . . . . 50

Freeze-Free Season...................... 52

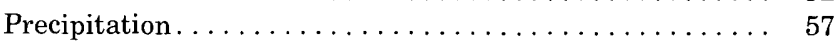

Average Annual Precipitation............. 58
Climatic Characteristics of the Delaware River Basin-Continued Precipitation-Continued

Average Annual Precipitation-Continued

Average December Precipitation.............. 60

Average January Precipitation............. 62

Average February Precipitation............ 64

Average March Precipitation............. 66

Average April Precipitation............... 68

Average May Precipitation.............. 70

Average June Precipitation. . . . . . . . . . . . 72

Average July Precipitation................... 74

Average August Precipitation............. 76

Average September Precipitation. . . . . . . . . 78

Average October Precipitation............ 80

Average November Precipitation........... 82

Average Winter Precipitation............... 84

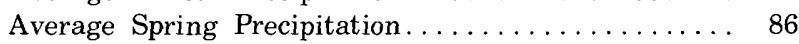

Average Summer Precipitation. . . . . . . . . . . . 88

Average Fall Precipitation................. 90

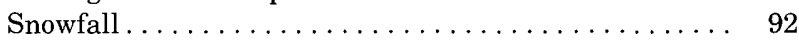

Precipitation Days ..................... 94

Average Monthly Dew-Point Temperature......... 95

Cloud Cover........................ 96

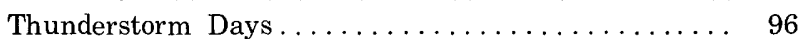

Climatic Water Budget................... 98

Water Budget for the Delaware River Basin . . . . . . . . . . 99

Potential Evapotranspiration.................. 99

Water Surplus.......................... 110

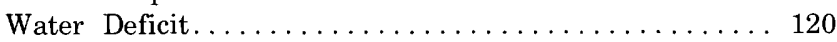

Drought ............................ 120

Hurricanes and Tropical Storms.................. 124

Selected References....................... 126

\section{ILLUSTRATIONS}

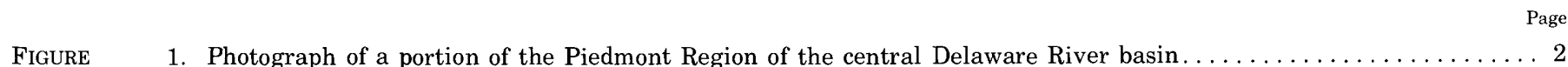
2-5. Maps showing:

2. Major physiographic features of the Delaware River basin $\ldots \ldots \ldots \ldots \ldots \ldots \ldots \ldots \ldots \ldots \ldots \ldots$

3. Locations of climatological stations used in the Delaware River basin $\ldots \ldots \ldots \ldots \ldots \ldots \ldots \ldots \ldots$

4. Typical summer daily 700 -millibar height contours above North America $\ldots \ldots \ldots \ldots \ldots \ldots \ldots \ldots$

5. Typical winter daily 700 -millibar height contours above North America $\ldots \ldots \ldots \ldots \ldots \ldots \ldots \ldots$

6. Diagram showing the relations between the upper level airflow pattern, paths of cyclonic systems,

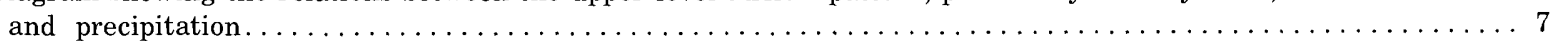

7. Map showing 500-millibar height contours above North America on January $19,1977 \ldots \ldots \ldots \ldots \ldots$

8. Map showing the 700-millibar height contours above the Northern Hemisphere on January $1978 \ldots \ldots \ldots \ldots \ldots$

9. Photograph showing the rugged terrain of the Catskill Mountains in the New York portion

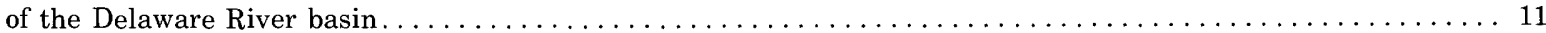

10. Graphs showing average annual temperature at four stations in the Delaware River basin,

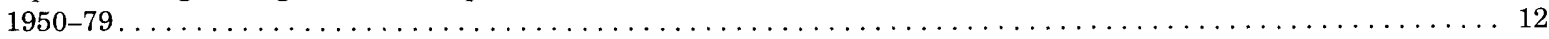

11. Map showing distribution of average annual temperature in the Delaware River basin $\ldots \ldots \ldots \ldots \ldots \ldots$

12. Graphs showing average December temperatures at four stations in the Delaware River basin,

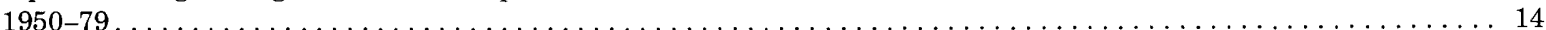


FIGURE 13. Map showing the distribution of average December temperatures in the Delaware River basin........... 15

14. Graphs showing average January temperatures at four stations in the Delaware River basin,

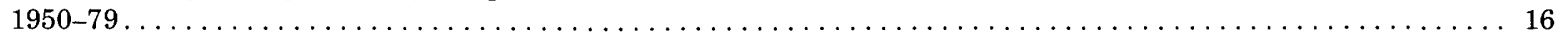

15. Map showing the distribution of average January temperatures in the Delaware River basin . . . . . . . 17

16. Graphs showing average February temperatures at four stations in the Delaware River basin,

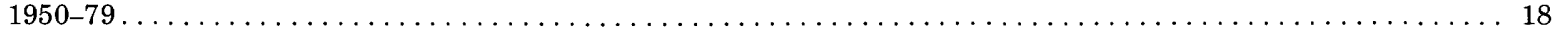

17. Map showing the distribution of average February temperatures in the Delaware River basin.......... 19

18. Graphs showing average March temperatures at four stations in the Delaware River basin,

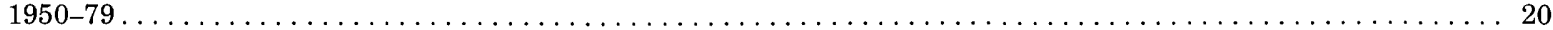

19. Map showing the distribution of average March temperatures in the Delaware River basin $\ldots \ldots \ldots \ldots \ldots \ldots \ldots$

20. Graphs showing average April temperatures at four stations in the Delaware River basin,

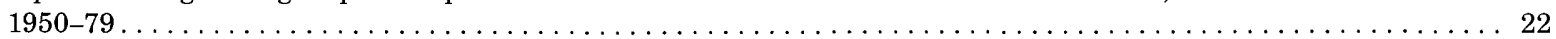

21. Map showing the distribution of average April temperatures in the Delaware River basin............ 23

22. Graphs showing average May temperatures at four stations in the Delaware River basin,

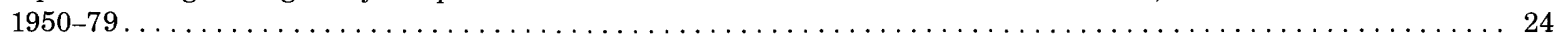

23. Map showing the distribution of average May temperatures in the Delaware River basin............. 25

24. Graphs showing average June temperatures at four stations in the Delaware River basin,

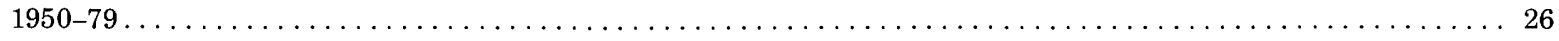

25. Map showing the distribution of average June temperatures in the Delaware River basin $\ldots \ldots \ldots \ldots \ldots \ldots$

26. Graphs showing average July temperatures at four stations in the Delaware River basin,

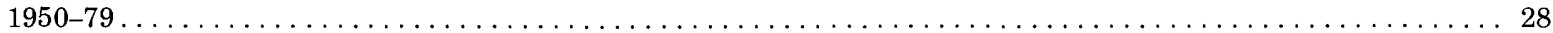

27. Map showing the distribution of average July temperatures in the Delaware River basin............ 29

28. Graphs showing average August temperatures at four stations in the Delaware River basin,

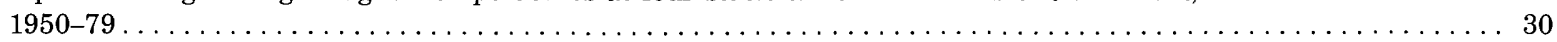

29. Map showing the distribution of average August temperatures in the Delaware River basin............ 31

30. Graphs showing average September temperatures at four stations in the Delaware River basin,

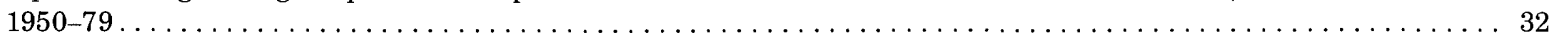

31. Map showing the distribution of average September temperatures in the Delaware River basin ........... 33

32. Graphs showing average October temperatures at four stations in the Delaware River basin,

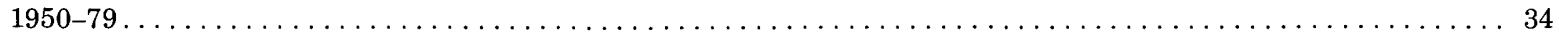

33. Map showing the distribution of average October temperatures in the Delaware River basin. . . . . . . . . . 35

34. Graphs showing average November temperatures at four stations in the Delaware River basin,

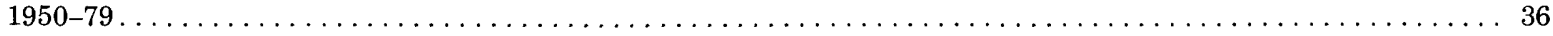

35. Map showing the distribution of average November temperatures in the Delaware River basin $\ldots \ldots \ldots \ldots \ldots \ldots 37$

36. Graphs showing average winter (December-February) temperatures at four stations

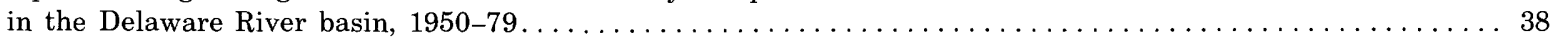

37. Map showing the areal distribution of average winter (December-February) temperatures

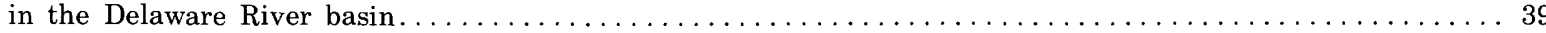

38. Graphs showing average spring (March-May) temperatures at four stations

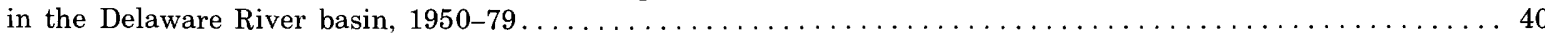

39. Map showing the areal distribution of average spring (March-May) temperatures

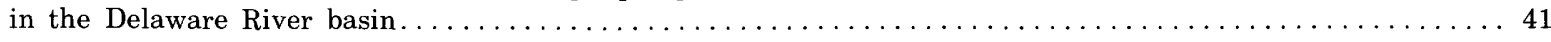

40. Graphs showing average summer (June-August) temperatures at four stations

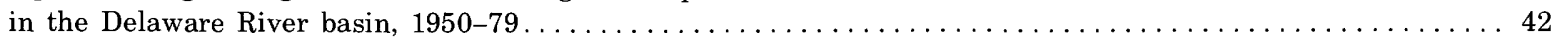

41. Map showing the areal distribution of average summer (June-August) temperatures

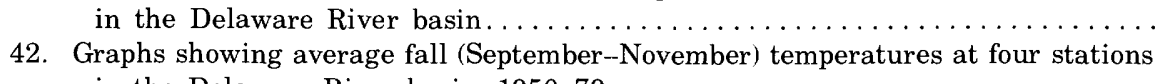

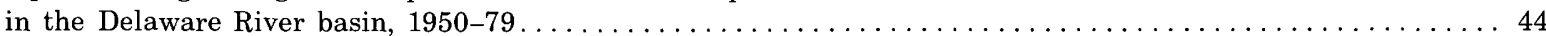

43. Map showing the areal distribution of average fall (September-November) temperatures

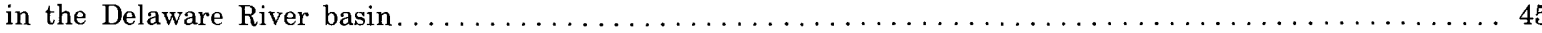

44-49. Graphs showing:

44. Monthly averaged daily minimum and maximum temperatures at three stations

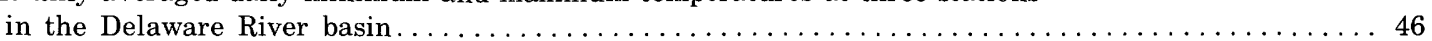

45. Average frequency of days per month of temperatures equal to or above $90{ }^{\circ} \mathrm{F}$ and

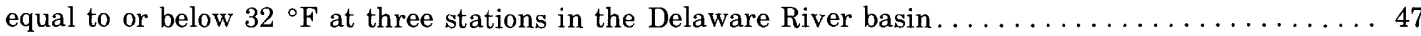

46. Average daily maximum and minimum temperatures for January and July,

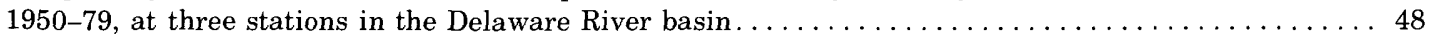

47. Average frequency of days per year of temperatures equal to or above $90{ }^{\circ} \mathrm{F}$ and equal to or below $32{ }^{\circ} \mathrm{F}$ at three stations in the Delaware River basin, $1950-79 \ldots \ldots \ldots \ldots$

48. Total annual heating degree days for three stations in the Delaware River basin. . . . . . . . . . . 50

49. Average monthly distribution of heating degree days for three stations in the Delaware River basin $\ldots \ldots \ldots \ldots \ldots \ldots \ldots \ldots \ldots \ldots \ldots \ldots \ldots \ldots \ldots \ldots \ldots \ldots \ldots \ldots$

50. Graphs showing the daily length of the freeze-free season at four stations in the Delaware River basin, 1950-79. 
FIGURE 51. Graphs showing the daily last minimum temperature in spring and first minimum temperature

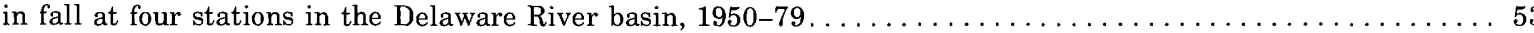

52-54. Maps showing:

52. Areal distribution of the average date of the last spring minimum temperature

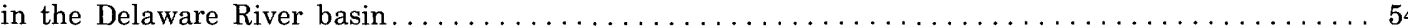

53. Areal distribution of the average date of the earliest fall minimum temperature

in the Delaware River basin........................................ 55

54. Areal distribution of the average length of the freeze-free season

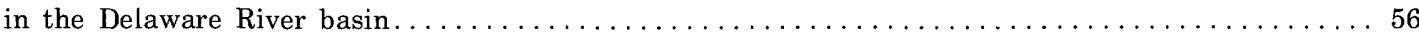

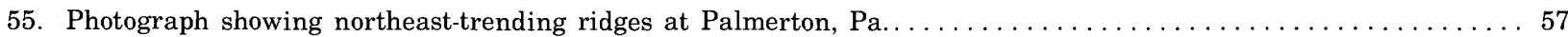

56. Graphs showing average annual precipitation at four stations in the Delaware River basin,

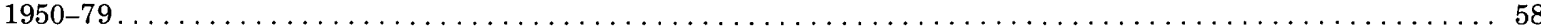

57. Map showing the areal distribution of average annual precipitation in the Delaware River basin......... 59

58. Graphs showing average December precipitation at four stations in the Delaware River basin,

59. Map showing the areal distribution of average December precipitation in the

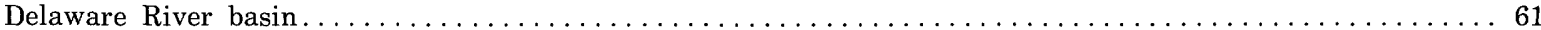

60. Graphs showing average January precipitation at four stations in the Delaware River basin,

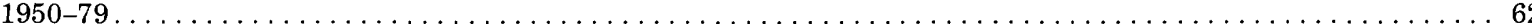

61. Map showing the areal distribution of average January precipitation in the Delaware River basin......... 63

62. Graphs showing average February precipitation at four stations in the Delaware River basin,

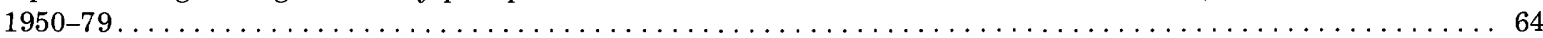

63. Map showing the areal distribution of average February precipitation in the Delaware River basin.........65

64. Graphs showing average March precipitation at four stations in the Delaware River basin, $1950-79 \ldots \ldots 66$

65. Map showing the areal distribution of average March precipitation in the Delaware River basin .........66

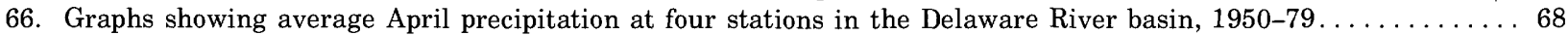

67. Map showing the areal distribution of average April precipitation in the Delaware River basin..........69

68. Graphs showing average May precipitation at four stations in the Delaware River basin, $1950-79 \ldots \ldots \ldots \ldots 70$

69. Map showing the areal distribution of average May precipitation in the Delaware River basin. . . . . . . . . 71

70. Graphs showing average June precipitation at four stations in the Delaware River basin, $1950-79 \ldots \ldots \ldots \ldots 72$

71. Map showing the areal distribution of average June precipitation in the Delaware River basin. . . . . . . . 73

72. Graphs showing average July precipitation at four stations in the Delaware River basin, $1950-79 \ldots \ldots \ldots \ldots$

73. Map showing the areal distribution of average July precipitation in the Delaware River basin $\ldots \ldots \ldots \ldots \ldots 75$

74. Graphs showing average August precipitation at four stations in the Delaware River basin,

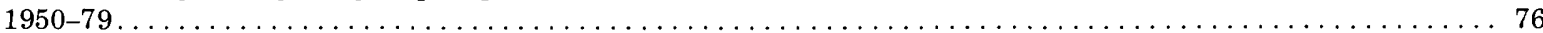

75. Map showing the areal distribution of average August precipitation in the Delaware River basin $\ldots \ldots \ldots \ldots \ldots \ldots 77$

76. Graphs showing average September precipitation at four stations in the Delaware River basin,

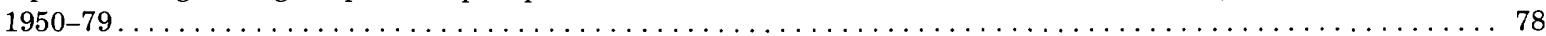

77. Map showing the areal distribution of average September precipitation in the Delaware River basin......... 79

78. Graphs showing average October precipitation at four stations in the Delaware River basin,

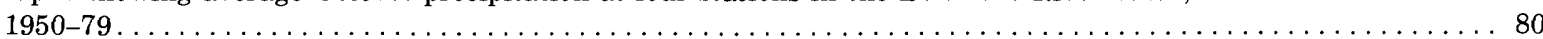

79. Map showing the areal distribution of average October precipitation in the Delaware River basin......... 81

80. Graphs showing average November precipitation at four stations in the Delaware River basin, $1950-79$

81. Map showing the areal distribution of average November precipitation in the

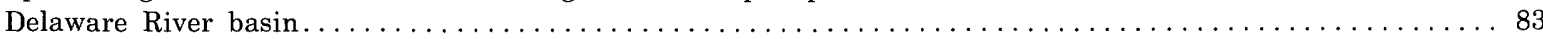

82. Graphs showing average winter (December-February) precipitation at four stations in the

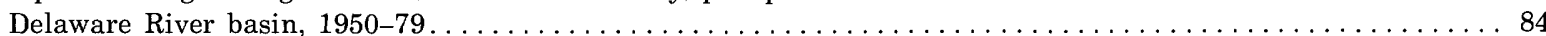

83. Map showing the areal distribution of average winter (December-February) precipitation in the

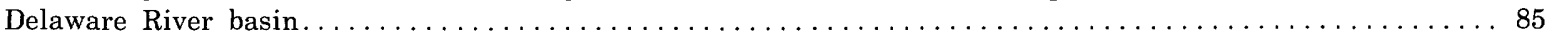

84. Graphs showing average spring (March-May) precipitation at four stations in the

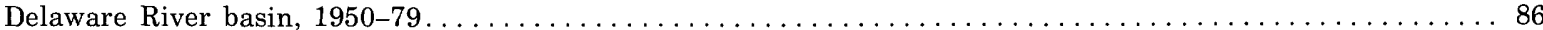

85. Map showing the areal distribution of average spring (March-May) precipitation in the

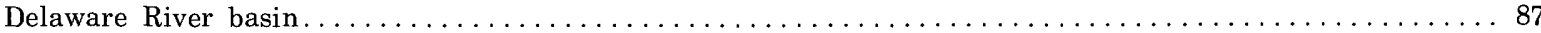

86. Graphs showing average summer (June-August) precipitation at four stations in the

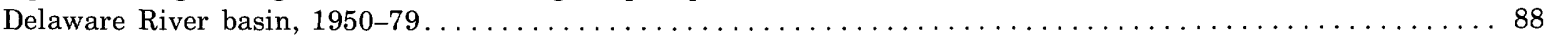

87. Map showing the areal distribution of average summer (June-August) precipitation in the

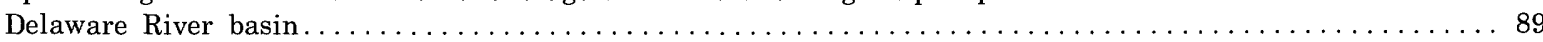

88. Graphs showing average fall (September-November) precipitation at four stations in the

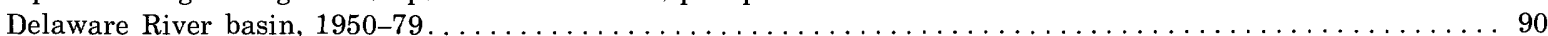

89. Map showing the areal distribution of average fall (September-November) precipitation

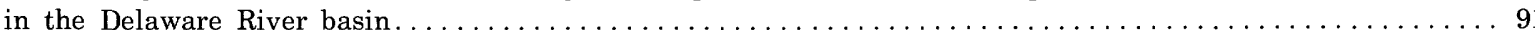


FiguRE 90-96. Graphs showing:

90. Total annual snowfall at three stations in the Delaware River basin, $1950-79 \ldots \ldots \ldots \ldots \ldots \ldots$

91. Average monthly snowfall at three stations in the Delaware River basin ................. 93

92. Average monthly precipitation days at three stations in the Delaware River basin............94

93. Average monthly dew-point temperature at three stations in the Delaware River basin.......... 95

94. Monthly percentage of clear, partly cloudy, and cloudy days for three stations in the Delaware River basin. . . . . . . . . . . . . . . . . . . . . 96

95. Annual percentage of clear summer and winter days at three stations in the

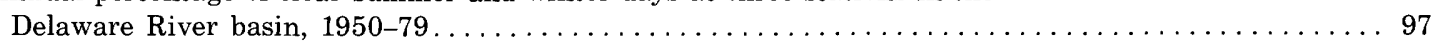

96. Average days per month of thunderstorm occurrence at three stations in the

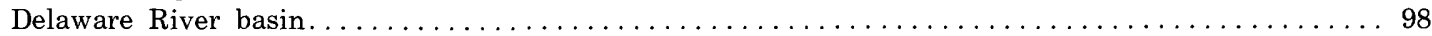

97. Photograph showing truck gardening in the southern New Jersey coastal plain. ................ 99 98-107. Maps showing:

98. Average annual potential evapotranspiration in the Delaware River basin. . . . . . . . . . . 100

99. Average March potential evapotranspiration in the Delaware River basin............... 101

100. Average April potential evapotranspiration in the Delaware River basin. . . . . . . . . . . . . 102

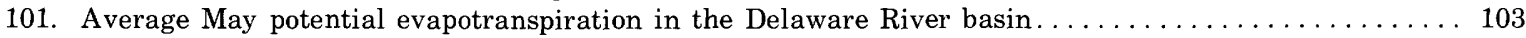

102. Average June potential evapotranspiration in the Delaware River basin . . . . . . . . . . . . . . . . 104

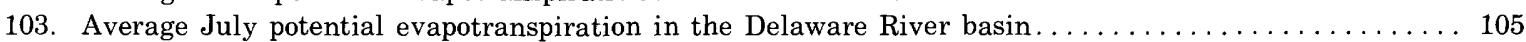

104. Average August potential evapotranspiration in the Delaware River basin . . . . . . . . . . 106

105. Average September potential evapotranspiration in the Delaware River basin. . . . . . . . . . 107

106. Average October potential evapotranspiration in the Delaware River basin .............. 108

107. Average November potential evapotranspiration in the Delaware River basin. . . . . . ........ 109

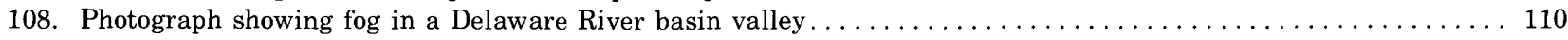

109. Map showing the areal distribution of average annual water surplus in the Delaware River basin......... 111

110. Graphs showing the average water surplus during winter (December-February) at four stations

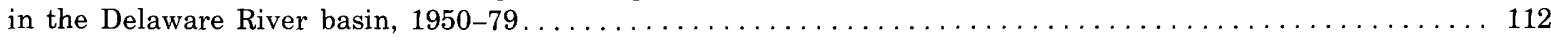

111. Map showing the areal distribution of average water surplus during winter (December-February)

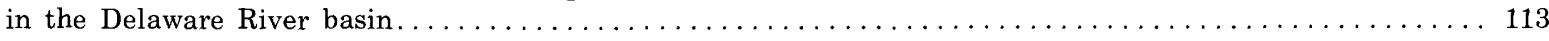

112. Graphs showing the average water surplus during spring (March-May) at four stations in the

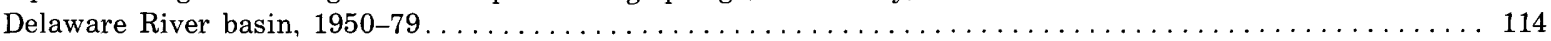

113. Map showing the areal distribution of average water surplus during spring (March-May)

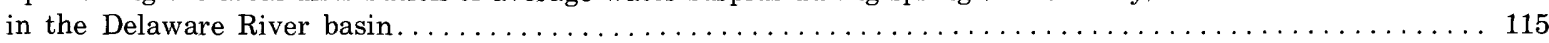

114. Graphs showing the average water surplus during summer (June-August) at four stations in the

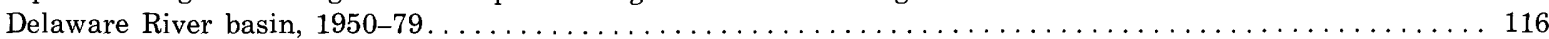

115. Map showing the areal distribution of average water surplus during summer (June-August)

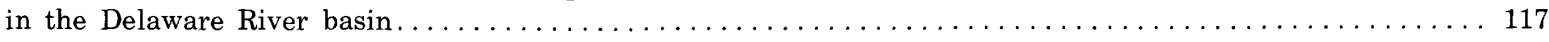

116. Graphs showing the average water surplus during fall (September-November) at four stations

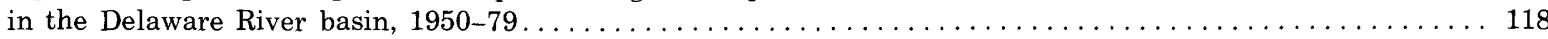

117. Map showing the areal distribution of average water surplus during fall (September-November)

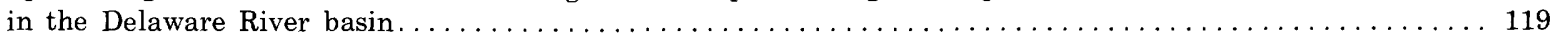

118. Graphs showing average annual water deficit at four stations in the Delaware River basin,

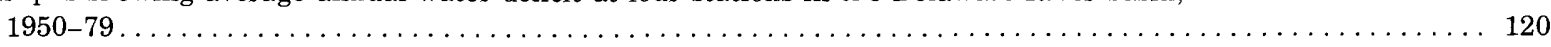

119. Map showing the areal distribution of average annual water deficit in the Delaware River basin.......... 121

120. Maps showing annual water deficits in the Delaware River basin during $A ; 1953, B ; 1954, C ; 1964$,

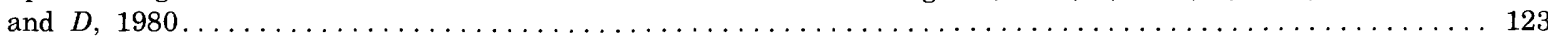

121. Map showing the path of hurricanes and tropical storms that affected the Delaware River basin, 1950-79. 


\section{METRIC CONVERSION FACTORS}

For readers who may prefer to use International System of Units (SI) rather than inch-pound units, the conversion factors for the terms used in this report are listed below:

Multiply

inch (in.)

foot (ft)

mile (mi)

degree Fahrenheit $\left({ }^{\circ} \mathbf{F}\right)$

miles per hour (mph)
By

25.40

0.3048

1.609

1.1507

${ }^{\circ} \mathrm{C}=5 / 9 \times\left({ }^{\circ} \mathrm{F}-32\right)$

0.447
To obtain

millimeter $(\mathrm{mm})$

meter (m)

kilometer $(\mathrm{km})$

nautical mile

degree Celsius $\left({ }^{\circ} \mathrm{C}\right)$

meters per second $(\mathrm{m} / \mathrm{s})$

\section{ALTITUDE DATUM}

Sea level: In this report "sea level" refers to the National Geodetic Vertical Datum of 1929 (NGVD of 1929)-a geodetic datum derived from a general adjustment of the first-order level nets of both the United States and Canada, formerly called Sea Level Datum of 1929 . 



\title{
CLIMATIC ATLAS OF THE DELAWARE RIVER BASIN
}

\author{
By Carol B. Jenner and Harry F. Lins
}

\begin{abstract}
The Delaware River basin is a diverse physiographic, hydrologic, and climatic region. The Delaware River serves as a major source of water for nearly 20 million people both in and outside the basin. Questions associated outside the variability of climate, the potential for climate change, and attendant implications for water resources and supply across this region in the coming decades require that there first be an appraisal of current climate conditions. To this end, graphs and maps for average monthly, seasonal, and annual values of temperature and precipitation across the basin during the period 1950-79 have been compiled in atlas form. Additional variables, including water budget terms, drought, cloud cover, hurricanes, and others have also been graphed and mapped.
\end{abstract}

\section{INTRODUCTION}

During the past decade the United States has been plagued by a series of anomalous weather events that have included record low snowfall for portions of the Western mountains, drought in the Northeast, extreme precipitation amounts in the Southwest, Great Basin, and Northern Great Lakes regions, and record cold and snowfall over much of the East. The effects of these events have been felt by virtually everyone, and the $\mathrm{Na}$ tion's agricultural, construction, and industrial sectors have been affected adversely.

Variability is a natural part of climate, and the extreme conditions of the last several years may be a part of normal climatic variability. They may, however, be a manifestation of a slightly changing climate. Most climatologists agree that Northern Hemisphere nearsurface temperatures over land increased by about $1.1^{\circ} \mathrm{F}$ from the late 19 th century to the 1940 's and then decreased into the early 1970's (Reitan, 1974; Brinkmann, 1976). Undoubtedly, other climatic variables also changed over this period; the precise nature of these changes is unknown because of a lack of appropriate data collection prior to the late 1940's.

Brinkmann (1979) has analyzed a Northern Hemisphere temperature curve that was determined using 280 stations having long-term records. When the individual records that contributed to the hemispheric curve were analyzed, it was found that some of those local records were in phase and some were out of phase with the average trend. For most of central and eastern North America, the temperature trends have paralleled the Northern Hemisphere average in a slightly amplified form. However, even the amplified local temperature changes seem minor. The importance of seemingly insignificant changes in average temperature is illustrated by Bryson and Murray (1977), who state that "an increase of $1{ }^{\circ} \mathrm{C}$ in summer temperatures in the northern plains can reduce the gross dollar of the spring wheat farmers by $\$ 131$ million...."

The importance of climatic information as an input to decisionmaking and research is being recognized in many fields that previously had ignored such data. Unfortunately, although massive amounts of climatic information are readily available from established government sources, these data are quite often not in a readily usable form. The most widely used average values of climatic data are climatic "normals." The normal value for a climatic parameter (such as January precipitation at a station) is defined as the average of that parameter over a three-decade period. Climatic normals are revised every 10 years. Values currently available for the United States cover the 1951-80 period. Although the use of average values of climatic parameters may provide sufficient climatological information for some applications in other fields, these values often do not give an adequate picture of climatic variability. In addition to mean values of temperature, precipitation, and so on, some idea of extreme values and frequencies of specific events would be of great importance in many research and planning decisions.

The purpose of this atlas is to present, in a form usable by planners, administrators, and policymakers, climatic information pertaining to one major watershed within the United States-the Delaware River basin. Data sources for the climatic information are the numerous publications of the National Oceanic and Atmospheric Administration.

The atlas incorporates several features that typically have not been included in other climatic data presentations. It discusses a naturally defined region (a drainage basin) rather than a region defined by political boundaries. Climatic variability is discussed with climatic average conditions. Finally, although it is impossible and impractical to analyze all combinations of climatic parameters, associations between temperature and precipitation are presented through the use of water-budget analysis. 
PHYSICAL SETTING

The Delaware River basin is diverse in topography, economic activity, and land use. The basin is approximately $270 \mathrm{mi}$ in length and contains some 7 million residents. It includes large industrial complexes and urban areas of extremely high population density as well as extensive farmland and wetland areas.

The basin includes portions of low, flat coastal plain and rolling Piedmont hills, the striking northeasttrending ridges of the ridge-and-valley section and the Catskills, the Poconos, and the Kittatinny Mountains of the Allegheny Plateau. Land-use patterns in the region are changing in response to urbanization and industrialization and, in part, as a result of changing lifestyles and the search for recreational opportunities (fig. 1).

The area is one of conflict between economic and environmental interests (United States Council on Environmental Quality, 1975). The controversy has been accentuated in recent years by increasing demands for fuel combined with shortages in high-quality fuel supply and record cold winters. The critical nature of water supply and demand was emphasized in 1980 and again in 1984-85 when severe drought conditions developed throughout the basin.

Major physiographic features of the Delaware River basin are shown in figure 2 .

\section{DATA COMPILATION}

This atlas of the Delaware River basin focuses on the climatic conditions for the 1950-79 period. All average values have been calculated for that period. In addition to average values for the period, time series of individual yearly values are graphed for representative stations. Thus average values as well as year-to-year variability in climatic parameters are presented. When this atlas was being prepared during 1980 , severe drought conditions developed in the Delaware River basin. The 1980 climatic data have been included in the sections on drought. Information on the 1984-85 drought, however, has not been included. For more information on this event, readers are referred to a recent paper by Harkness and others (1986).

Data for the atlas came from readily available published sources, mainly climatological data for individual States and "Climatological Data, National Summary," published by the Environmental Data Service of the National Oceanic and Atmospheric Administration (NOAA).

For most of the stations included in this report, temperature and precipitation data are collected daily by volunteer cooperative observers. At a few selected firstorder stations, usually located at major airports, NOAA personnel collect and record a much more comprehen-

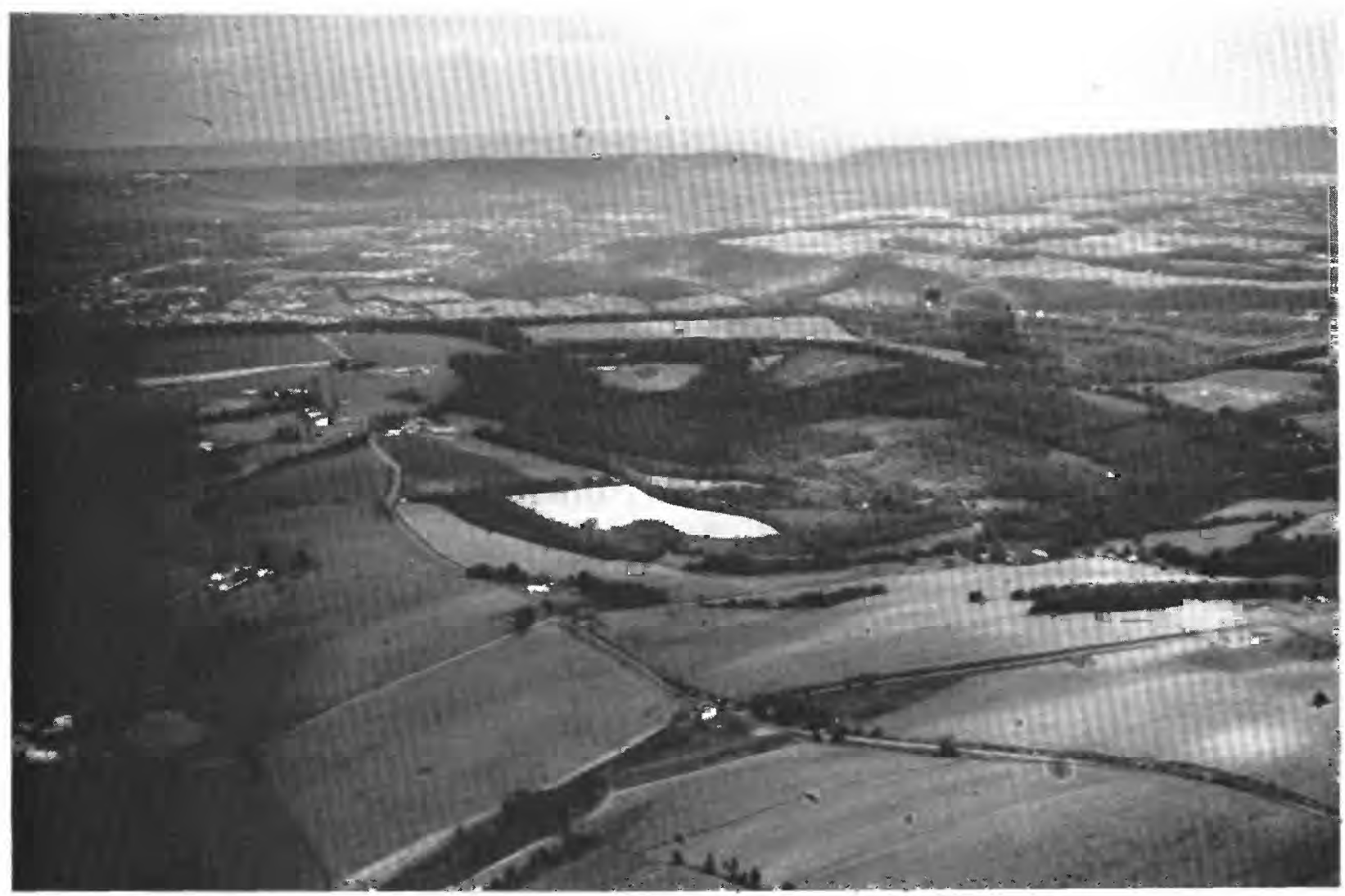

FIGURE 1.-Pastureland and agricultural fields west of Philadelphia, Pa., are typical of the Piedmont region of the central Delaware River basin. 


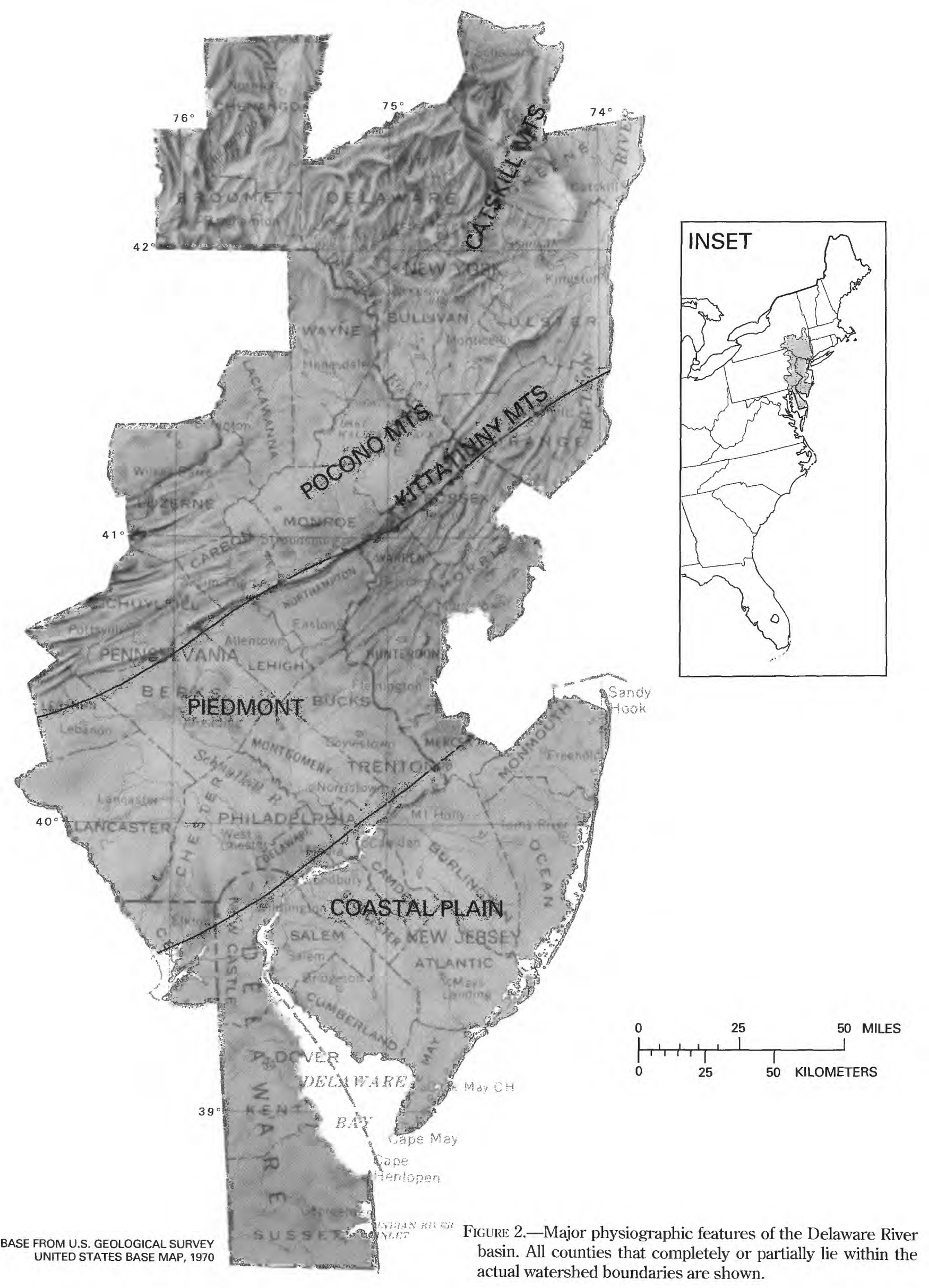


sive set of climatological data. All of this information is published on a statewide basis.

Records are generally of high quality. One difficulty encountered when using this network was that some of the stations had been relocated during the period of study. Stations that experienced major changes in location during the 1950-79 period were omitted from this study.

Occasionally, station data were missing or unreported in the published sources. A station was omitted from this analysis if 10 percent or more of the monthly average temperature or precipitation values were missing. In the case of a station with a few missing values, these values were estimated by means of regression relations developed using the appropriate time series of data from nearby stations.
In all, 49 stations provided temperature data, and 82 stations provided precipitation data. Station locations are plotted on figure 3. For the time series plots of yearly data, four stations, Georgetown, Del., Indian Mills, N.J., Belvidere, N.J., and Hawley, N.Y., were chosen to make up a north-south transect within the basin. For depiction of more specialized climatological data collected and (or) published for first-order stations only, Wilmington, Del., Allentown, Pa., and Binghamton, N.Y., were selected.

All contour maps were constructed by the University of Wisconsin Cartographic Laboratory using the weighted-distance contouring algorithm of the computermapping package WISMAP.
1. Norwich, N.Y.

2. Kortright 2, N.Y.

3. Stamford, N.Y.

4. Lake Delaware, N.Y.

5. New Kingston, N.Y.

6. Binghamton WSO AP, N.Y.

7. Arkville 2W, N.Y.

8. Deposit, N.Y.

9. Frost Valley, N.Y.

10. Claryville, N.Y.

11. Equinunk $2 W N W$, N.Y.

12. Grahamsville, N.Y.

13. Liberty 1 NE, N.Y.

14. Mohonk Lake, N.Y.

15. Pleasant Mount $1 \mathrm{~W}, \mathrm{~Pa}$.

16. Honesdale $4 \mathrm{NW}, \mathrm{Pa}$.

17. Hawley, Pa.

18. Paupack 2WNW, Pa.

19. Hollisterville, $\mathrm{Pa}$.

20. Port Jervis, N.Y.

21. West Point, N.Y.

22. Matamoras, $\mathrm{Pa}$.

23. Wilkes-Barre 4NE, $\mathrm{Pa}$.

24. Gouldsboro, $\mathrm{Pa}$.

25. Sussex 1SE, N.J.

26. Long Pond 2W, Pa.

27. Newton, N.J.

28. Charlotteburg Reservoir, N.J.

29. Freeland, Pa.

30. Stroudsburg, Pa.

31. Kresgeville 2W, $\mathrm{Pa}$.

32. Boonton 1SE, N.J.

33. Tamaqua 4N Dam, Pa.

34. Lehighton, $\mathrm{Pa}$.

35. Belvidere, N.J.

36. Palmerton, $\mathrm{Pa}$.

37. Tamaqua, $\mathrm{Pa}$.

38. Long Valley, N.J.

39. New Tripoli 4E, Pa.

40. Allentown WSO AP, Pa.

41. Claussville, $\mathrm{Pa}$.
42. Port Clinton, Pa.

43. Flemington 3E, N.J.

44. Strausstown, $\mathrm{Pa}$.

45. Zionsville 3SE, Pa.

46. Palm 3SE, $\mathrm{Pa}$.

47. Myerstown, $\mathrm{Pa}$.

48. Reading $3 \mathrm{~N}, \mathrm{~Pa}$.

49. Lambertville, N.J.

50. Doylestown, $\mathrm{Pa}$.

51. Hightstown 2W, N.J.

52. Freehold, N.J.

53. Graterford 1E, Pa.

54. George School, $\mathrm{Pa}$.

55. Trenton WSO CI, N.J.

56. Ephrata, Pa.

57. Neshaminy Falls, Pa.

58. Phoenixville $1 \mathrm{E}, \mathrm{Pa}$.

59. Norristown, Pa.

60. Devault $1 \mathrm{~W}, \mathrm{~Pa}$.

61. Conshohocken, $\mathrm{Pa}$.

62. Coatesville, 1SW, Pa.

63. West Chester $1 \mathrm{~W}, \mathrm{~Pa}$.

64. Moorestown, N.J.

65. Drexel Institute, $\mathrm{Pa}$.

66. Pemberton 3S, N.J.

67. Philadelphia WSO AP, Pa.

68. Audubon, N.J.

69. Chadds Ford, Pa.

70. Holtwood, Pa.

71. Marcus Hook, Pa.

72. Indian Mills 2W, N.J.

73. Porter Reservoir, Del.

74. Newark, Del.

75. Wilmington WSO AP, Del.

76. Hammonton 2 NNE, N.J.

77. Shiloh, N.J.

78. Dover, Del.

79. Milford 2WSW, Del.

80. Lewes 1SW, Del.

81. Bridgeville $1 \mathrm{NW}$, Del.

82. Georgetown 5SW, Del. 


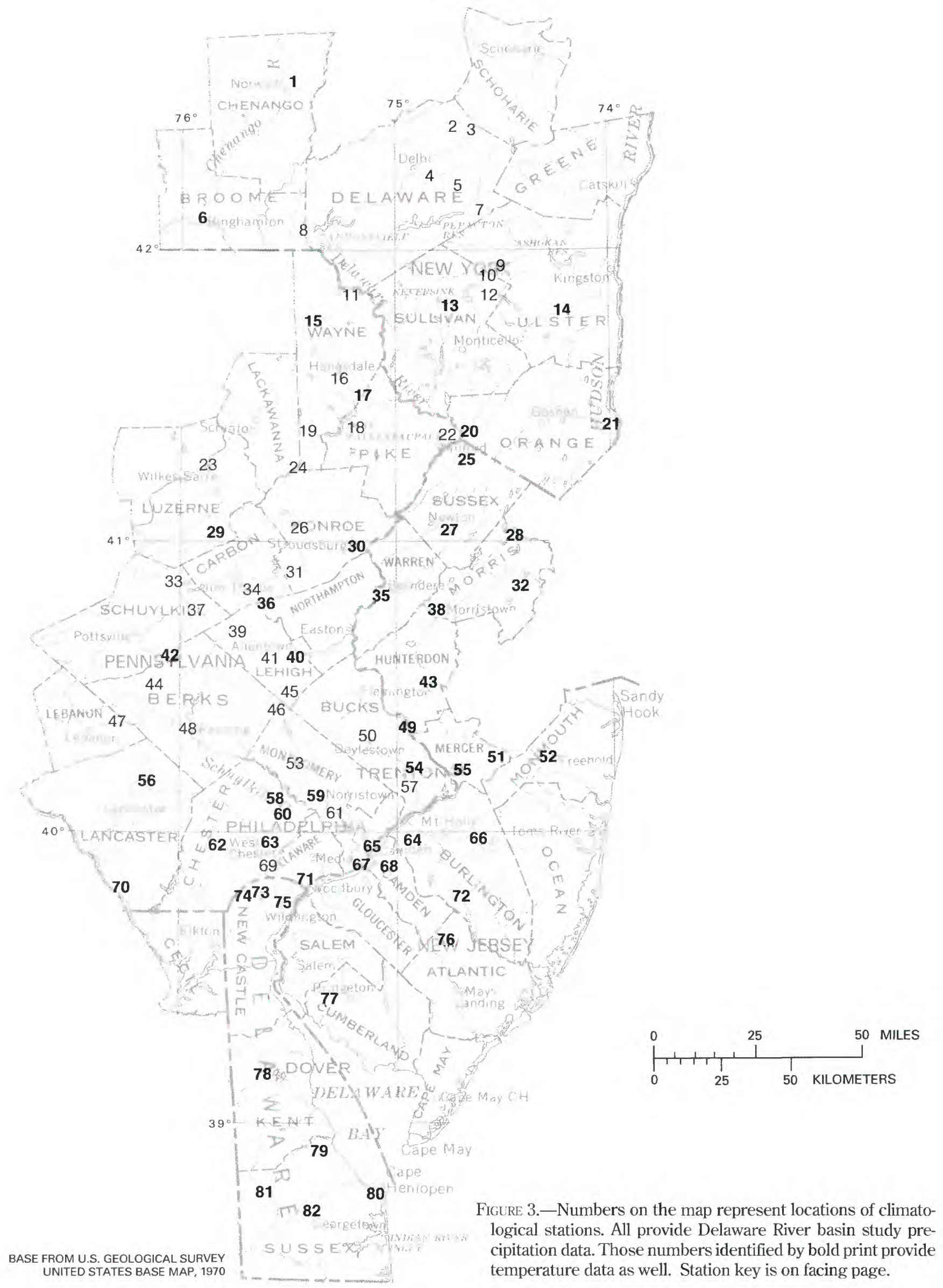




\section{CLIMATIC VARIABILITY}

\section{CIRCULATION OF THE MIDLATITUDES}

Energy imbalances between tropical and polar regions exist because of variations in solar energy receipt. To resolve these imbalances, transfer of energy poleward from equatorial areas, across the middle-latitude regions, is necessary. It is the function of the atmospheric circulation system to achieve this transfer of energy. The middle-latitude regions are the zones across which the maximum amount of energy transfer is accomplished. At the surface, much of this energy transfer takes place at the polar front, the boundary between air masses of polar origin and those of the warmer, more humid tropics. Migrating cyclonic systems form and migrate along the polar front and achieve energy transfer through the mixing of the contrasting air masses. Horizontal waves in the upper level westerlies, which are also important for the meridional transfer of energy, are connected to the low-level cyclonic systems.

It is convenient to consider flow at levels above the frictional influence of the surface when examining circulation characteristics in the midlatitudes. Atmospheric pressure decreases with height above the surface. Upper air data are collected at numerous points above the Earth's surface corresponding to particular values of atmospheric pressure rather than to specific elevations above sea levels. Two of these levels, the 700-millibar level at around $10,000 \mathrm{ft}$ and the 500-millibar level at about $18,000 \mathrm{ft}$, are frequently chosen when discussing upper air relations with surface weather. The actual height of each surface varies spatially at a given time, related to thermal and dynamic causes. Thus for every station in an upper air data network, information collected includes the elevation of each significant pressure surface (mean sea level) as well as temperature, humidity, and wind information.

The height at which a significant atmospheric pressure value occurs varies spatially, and the topography of a constant pressure surface is frequently depicted by isolines of constant elevation above mean sea level. On such maps, relatively high contour heights are associated with relatively high atmospheric pressure and a relatively warm atmospheric column. Relatively low contour heights are associated with low pressure and a relatively cool atmospheric column. Zones of steepest slopes on the constant pressure surface are zones of strongest atmospheric temperature gradient in the horizontal.

At upper levels, the forces affecting atmospheric motion are the pressure gradient force, which causes flow from high to low pressure areas, and the Coriolis deflection, which acts to the right of the flow in the Northern Hemisphere. The equilibrium flow in the upper levels, away from frictional effects of the Earth's sur- face, is parallel to the height contours of a constant pressure surface with low pressure to the left of the airflow path (in the Northern Hemisphere). Thus, by examining the topography of a constant pressure surface, one can determine the associated airflow pattern.

The height of the 700-millibar surface over North America for a typical summer day is shown in figure 4. The contour lines exhibit wavelike irregularities, but in general the 700-millibar surface slopes downward from south to north. The steepest slopes in the 700-millibar surface, associated with the steepest atmospheric pressure and temperature gradients, occur in the Gulf of Alaska and off the Newfoundland coast. These areas are patterned in figure 4 . The steepest pressure gradients over the continent occur in southern Canada and are associated with the summer polar front. The arrows in figure 4 indicate the direction of airflow. In this situation, where the wind is flowing in an almost perfect westto-east fashion, the flow is termed "zonal."

An example that contrasts greatly with the zonal situation discussed above is shown in figure 5 , which depicts a 700-millibar surface for a typical winter day. Here again, the highest 700-millibar surface heights are found in the southern areas, and the lowest heights occur in the north. A parcel of air embedded in the associated airflow would, in the long run, be transported from west to east. A well-developed wave with a "ridge" of relatively high pressure above western Canada and

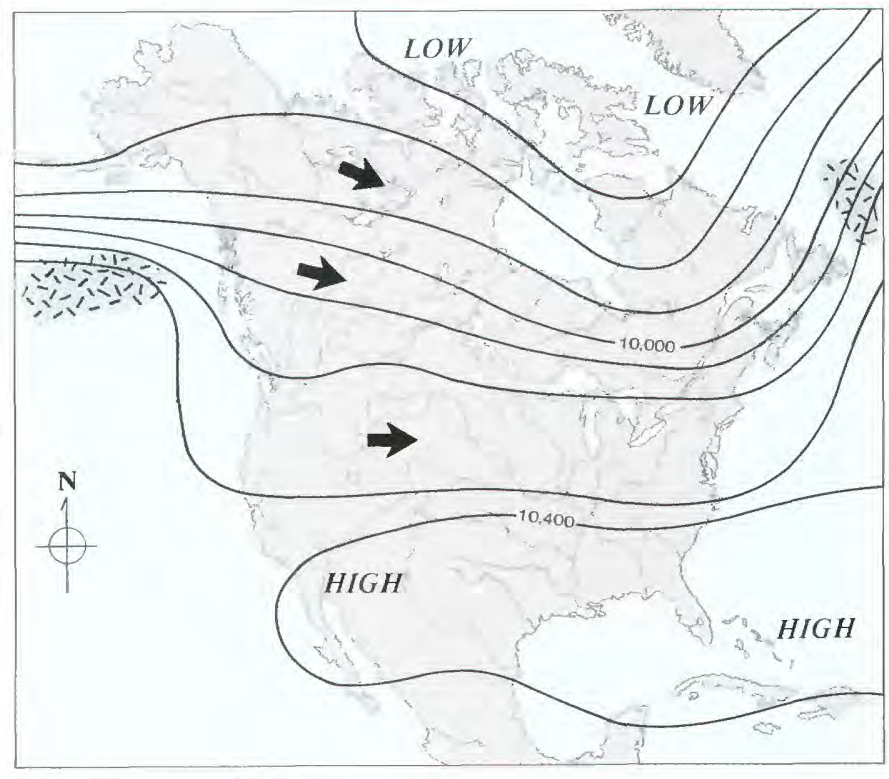

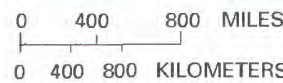

FIGURE 4.- Typical summer daily 700-millibar height contours (in feet) above North America. Steepest slopes in the 700-millibar surface associated with steepest atmospheric pressure and temperature gradients are patterned. Arrows indicate direction of airflow. 
a "trough" of relatively low pressure extending from Hudson Bay into the southeastern United States is shown in figure 5. A strong northerly component to the airflow is present at point $A$, and a strong southerly component exists at point $B$. This is a good example of strong "meridional" flow.

\section{RELATION OF UPPER AIR FLOW TO SURFACE WEATHER}

The circulation at upper levels appears to be a much smoothed-out version of the familiar surface weather map. It has considerable influence on weather conditions at the surface.

Temperature conditions in the atmospheric column are related to the height of a particular pressure surface. In a cold column of air, atmospheric pressure decreases relatively rapidly with height, and the 700-millibar height is relatively low. In a warm air column, the pressure decrease with height is less, and the 700-millibar surface is at a relatively high altitude above sea level.

The polar front, the belt of strongest westerly winds, marks the zone of sharp contrast in air mass temperatures, separating relatively cool (or cold) air of polar origin from warm tropical air masses. The position of the polar front and the nature of the horizontal wave pat-

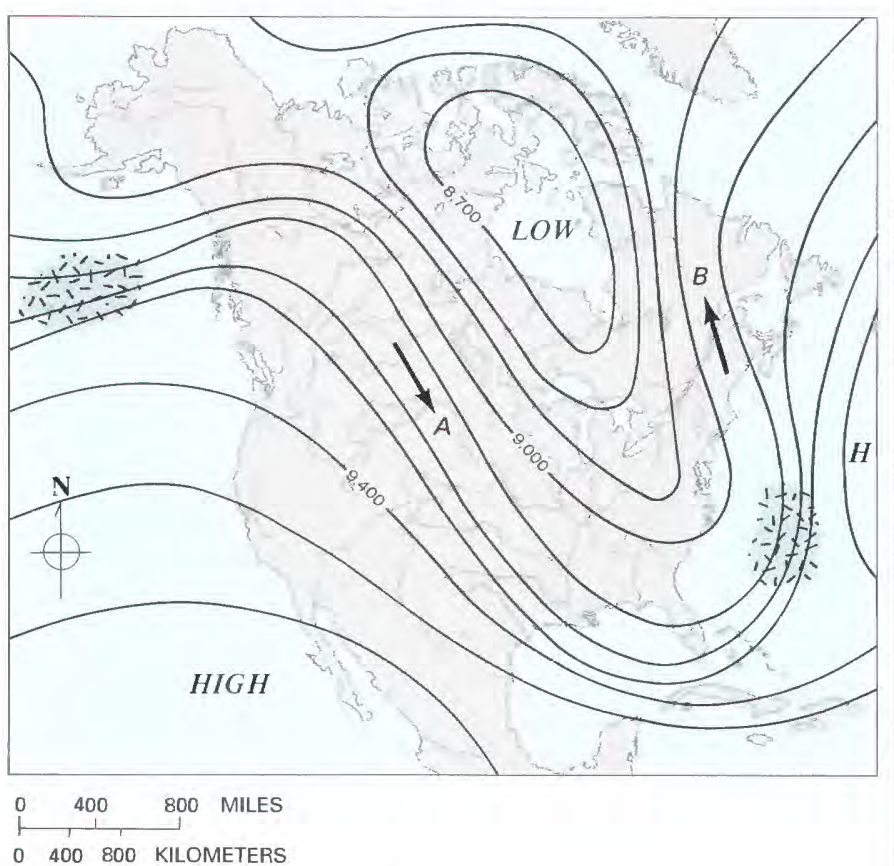

FIGURE 5.-Typical winter daily 70)(-millibar height contours (in feet) above North America. Steepest slopes in the 700-millibar surface associated with steepest atmospheric pressure and temperature gradients are patterned. Arrows indicate direction of airflow. A strong northerly component to airflow is present at point $A$. A strong southerly component to airflow is present at point $B$. tern of the upper level flow are important in determining temperature characteristics at the surface.

The upper level circulation also has an important affect on precipitation patterns. The contours shown in figure 6 represent a typical ridge-trough configuration in upper level airflow. Areas ahead of the trough favor convergence and upward motion near the surface and thus encourage precipitation. Migrating cyclonic systems tend to form in these areas and are subsequently steered by the general upper level flow. Areas behind the trough are areas of subsidence and divergence and tend to be regions of little precipitation.

The location of upper level troughs is very important, therefore, in affecting precipitation receipt. A slight change in the average position of a trough can result in serious precipitation deficits in one area and abnormally high precipitation totals in another.

General Characteristics for North America.-Wave trough and ridge axes may be located at any latitude. Typically three to seven waves exist around the hemisphere at one time. Ridges and troughs seem to have preferred locations related to mechanical and thermal influences. North-south-trending mountain ranges, such as the Rocky Mountains, cause convergence in the vertical of air flowing from the west to east. If constant absolute vorticity of the airflow is to be maintained, clockwise airflow should occur to the lee (east) of the barrier. This is a partial explanation for the frequent occurrence of a ridge over western North America. Thermal characteristics, such as contrast between a snow-covered land mass and nearby, relatively warm ocean waters, can often contribute to the anchoring of an atmospheric wave

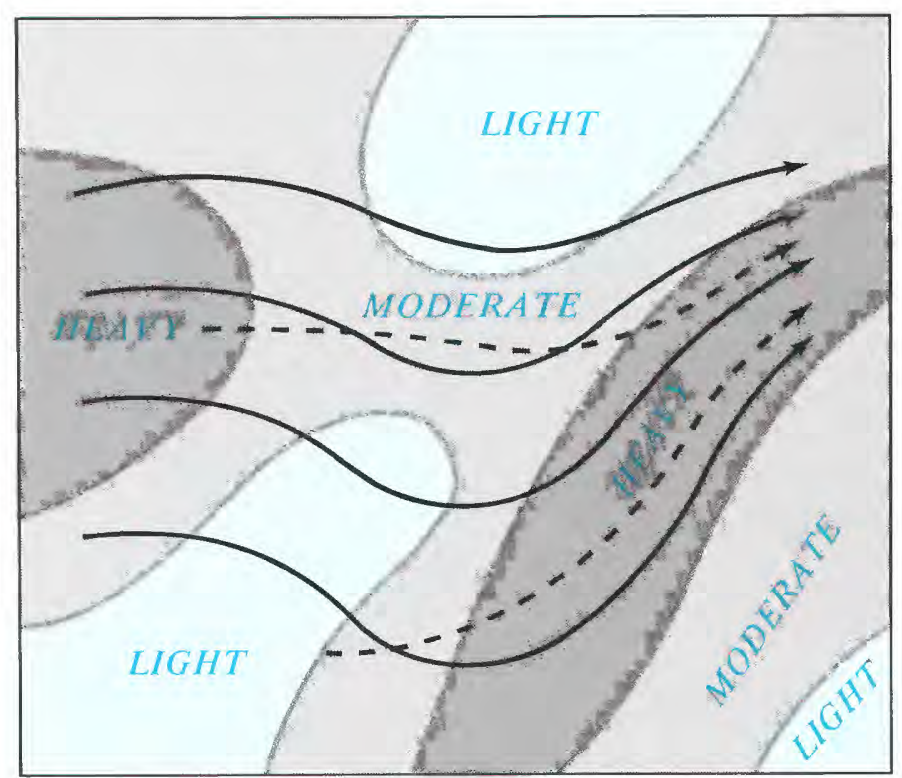

FIGURE 6.- Relations between the upper level airflow pattern (solid arrows), paths of cyclonic systems (dashed arrows), and precipitation (shaded areas). After Harman, 1971. 
pattern. Fixing in unusual locations results in anomalous weather associated with all parts of the wave.

During winter, circulation in North America is vigorous with well-defined wave patterns and sharp boundaries between contrasting air masses. Migrating storms are steered in rapid succession along tracks related to the prevailing upper air flow. In summer the circulation weakens, and the strongest westerlies occur at the latitude of southern Canada. Only rarely do vigorous cyclonic systems affect the middle latitude regions of the continental United States during summer.

\section{ATMOSPHERIC CIRCULATION AND CLIMATIC VARIABILITY}

On very short time scales, anomalous weather events may be associated with unusual upper level circulation features. The January 19, 1977, extreme cold weather along the Atlantic Coast is one such example. The upper air charts for that day (fig. 7) show extremely strong pressure gradients with a deep trough centered over Eastern Canada. This caused the rapid transport of polar air to the Southeastern United States. Adding to the extreme effect was the cold weather in the Midwest and South that had preceded this event. This upper air circulation resulted in airflow over abnormally cold land surfaces; snow flurries occurred in the Miami, Fla., area. During the same period, the Gulf of Alaska experienced record high temperatures because of an unusually strong southerly flow component (Wagner, 1977).

If unusual upper level circulation features recur or persist within a several-week period, the effect may appear in monthly average pressure and airflow conditions as well as in surface temperature and precipitation averages. A good example is the case of January 1978 (see fig. 8). During this month, a persistent anomalous upper air flow, which featured an eastern seaboard trough displaced slightly west of normal, resulted in high precipitation totals in the Eastern United States. A series of cyclonic systems formed along the Gulf Coast and moved eastward and northward along the Atlantic Coast. Average monthly temperatures were far below normal over the United States east of the Rocky Mountains. Record or near-record precipitation totals were received over much of the eastern half of the country (Wagner, 1978).

On even longer time scales, a series of anomalous years can result in decadal averages significantly different from the norm. The three winters of 1976-77, 1977-78,

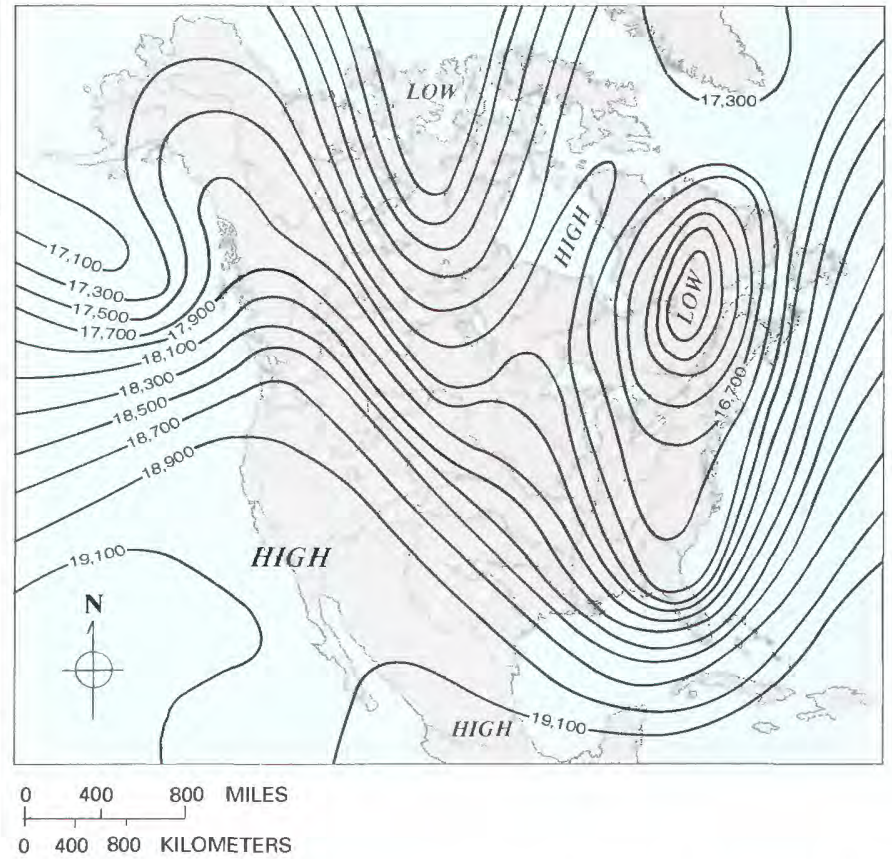

Figure 7.- Shown are 500-millibar height contours (in feet) above North America on January 19, 1977. (From U.S. Department of commerce, NOAA, Daily Weather Map Series.)

and 1978-79 with accompanying record cold and snowfall will certainly dominate the climatic picture of the 1970's for most of the Eastern United States.

Evidence indicates that some individual circulation anomalies can be traced from season to season and sometimes from year to year. Several examples of selfperpetuating mechanisms operating between sea surface-temperature anomalies and circulation anomalies have appeared in the literature. Namias (1974) has suggested that the unusual weather events of the 1972-73 water year might be related to anomalous sea surface temperatures in the Pacific. Namias (1966) has also pointed out that the 1962-65 drought that affected the Northeast was associated with an eastward displacement of the trough normally situated along the east coast. The anomalous flow component affecting the Northeast was from the northwest, and an unusually warm, dry airflow resulted. Namias suggests that a pool of unusually cool water off the Atlantic coast might have stabilized the drought pattern.

The unusually high amplitude wave over North America (see figs. 7 and 8), which prevailed for three winters (1976-77, 1977-78, and 1978-79), may have been related to persistent sea surface-temperature anomalies in the Pacific Ocean. 


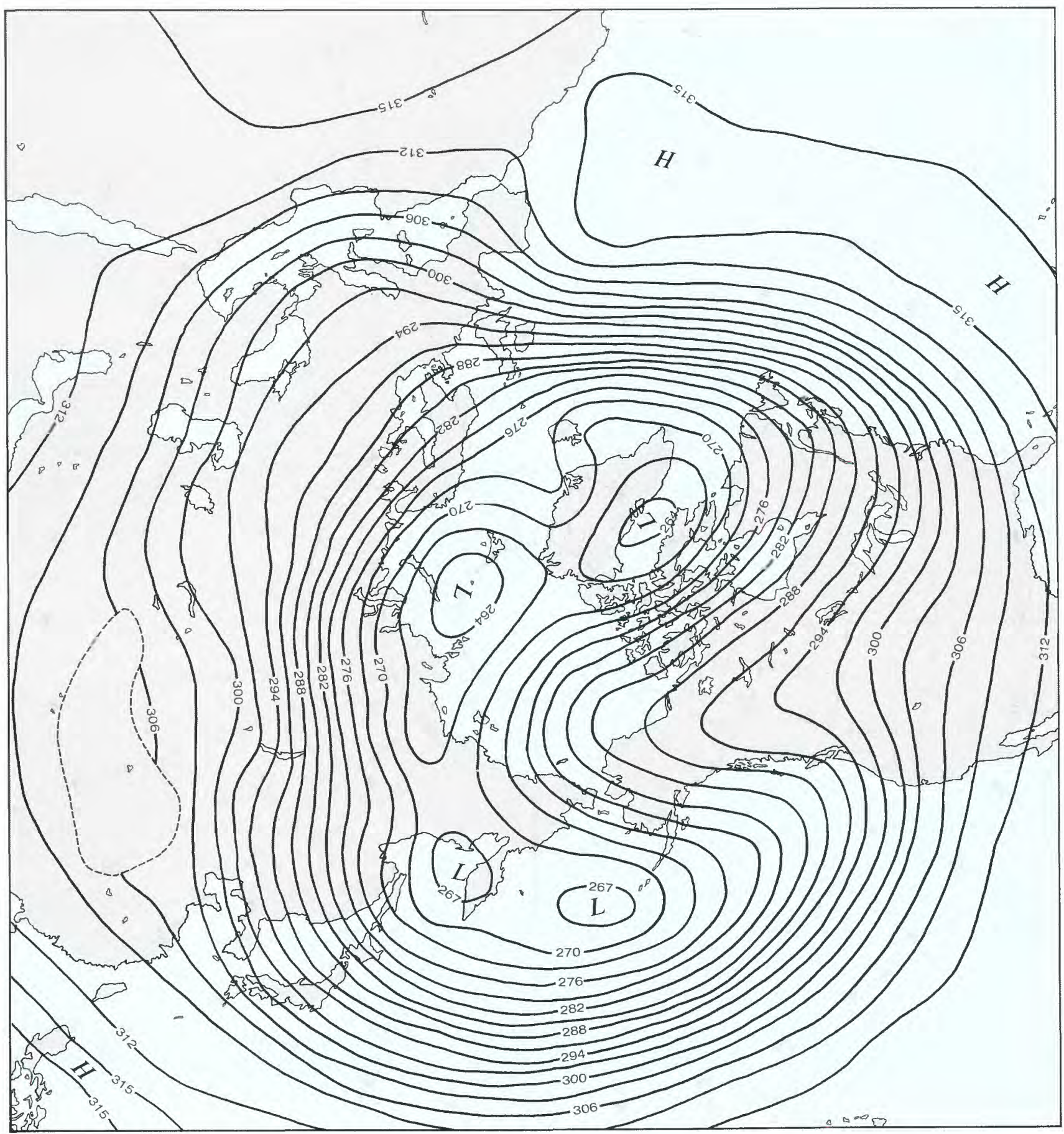

Figure 8.-Monthly mean 700-millibar height contours (in dekameters) above the Northern Hemisphere for January 1978 (from Wagner, 1978). Contour interval is 3 dekameters (98.4 feet). H, high; L, low. 


\section{CLIMATIC CHARACTERISTICS OF THE DELAWARE RIVER BASIN}

The weather in the Delaware River basin is characterized by the seasonal weather changes typical of a temperate humid climate. The Atlantic Ocean to the east moderates temperature extremes to a certain extent, but this effect is not always evident because prevailing winds are westerly. Annual precipitation totals range from 35 to $40 \mathrm{in}$. in the southern and western portions of the basin to over $50 \mathrm{in}$. in the northern areas, where terrain effects are apparent. Storms moving parallel to the Atlantic coast from the Gulf of Mexico are important precipitation-producing systems during the winter months. In summer, warm, moist air is circulated into the area by the Bermuda high and scattered convective showers contribute the bulk of the precipitation. Occasional tropical storms move into the area. The high rainfall totals associated with these systems interrupt the otherwise even distribution of precipitation through the year.

In general, cold month average temperatures are slightly above freezing in the southern portions of the basin and about $25{ }^{\circ} \mathrm{F}$ in the north. Warm month average temperatures range from $70^{\circ} \mathrm{F}$ to almost $80^{\circ} \mathrm{F}$. During all times of the year, local influences can have profound effects on temperature. Cold air drainage, urban heat-island effects, oceanic influences, and altitude all play a role in determining temperature regimes within the basin.

\section{TEMPERATURE}

The following series of illustrations shows average monthly and seasonal temperature characteristics for the stations in the Delaware River basin counties. Accompanying each map are times series plots for four stations selected to follow a north-south transect within the basin.

Cooperative observers record daily maximum and minimum temperatures from instruments housed in shelters approximately $4 \mathrm{ft}$ above the ground. The average daily temperature is calculated as the average of the two daily extreme values. The monthly average temperature is the average of these daily values. In interpreting the maps and applying any of these data to a specific problem, allowance for local influences on temperature should be made. In areas of little relief and extensive, homogeneous land cover, the air temperature measured at a station may well represent a much larger area around the station. In areas of high relief, however, there may be rather great differences in thermal characteristics of a valley and those of adjacent ridgetops. Slope and exposure of a surface affect the amount of solar radiation absorbed and the amount of surface heating; great variability may exist in a small area when relief features are pronounced, as in the northern portions of the Delaware River basin (see fig. 9). In general, temperature decreases with altitude. However, under certain weather conditions accompanied by clear skies and calm winds, cool air tends to flow toward low spots in the terrain. Then temperature inversion conditions exist and valleys are actually cooler than adjacent ridges. If sufficient moisture is present in the atmosphere, fog may form in the cooler air of lower elevations.

The land cover and land use around a station also influence the representativity of temperature measurements taken. Local surface characteristics such as reflectivity of incoming solar radiation (albedo), thermal conductivity and heat capacity of the surface materials, and moisture characteristics determine the amount of incoming solar radiational energy that ultimately is used to heat the atmosphere above the surface. A great contrast in these parameters exists between typical urban surfaces and vegetated rural surfaces. Differences in surface characteristics and building geometry along with emission of waste heat by industry and by domestic heating result in urban temperatures being higher, on the average, than temperatures recorded in the surrounding rural countryside. In the Delaware River basin, the urban influence on temperature is dramatically illustrated in the Philadelphia, Pa., area. 


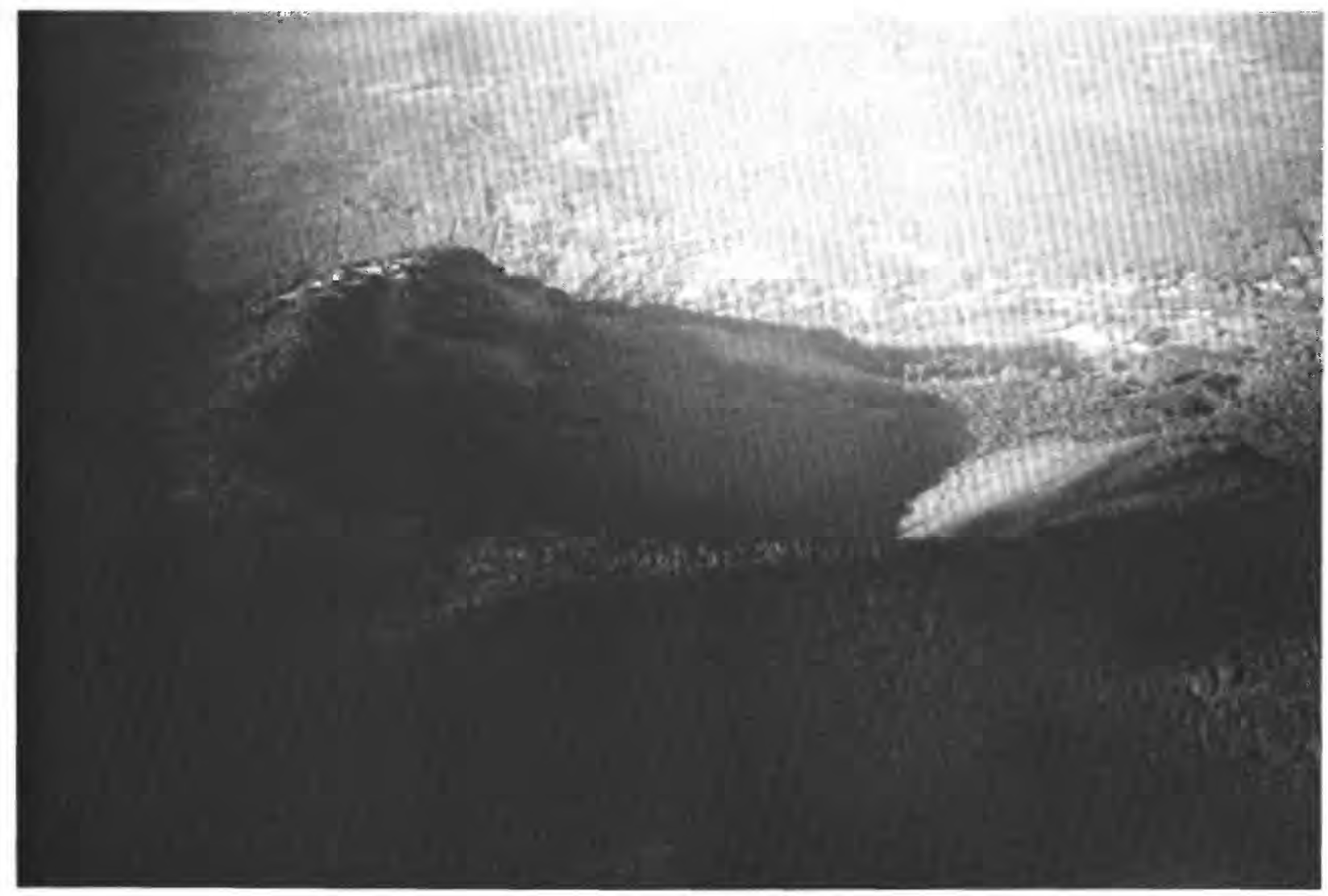

FIGURE 9.-The rugged terrain of the Catskill Mountains in the New York portion of the Delaware River basin leads to great variability in temperature and precipitation characteristics over small areas. 


\section{AVERAGE ANNUAL TEMPERATURE}

The influences of latitude, station elevation, and urbanization affect the distribution of annual average temperature within the Delaware River basin (figs. 10 and 11). A systematic latitudinal decrease in temperature in the southern portion of the basin is interrupted by the urban heat-island effect in the Philadelphia area. In the northern half of the basin, significant terrain effects result in relatively low average annual temperatures in the high elevations of the Poconos and the Catskills. The Delaware stations generally have average temperatures in the $54-55^{\circ} \mathrm{F}$ range, and the stations in the northern portion of the basin show averages in the $44-46^{\circ} \mathrm{F}$ range. Dover, Del., has the highest average annual temperature of $56.2^{\circ} \mathrm{F}$; Pleasant Mount, $\mathrm{Pa}$., has the lowest average annual temperature of $42.9^{\circ} \mathrm{F}$. Time series plots (fig. 10) of the annual values for the four representative stations show the year-to-year variability in this parameter.

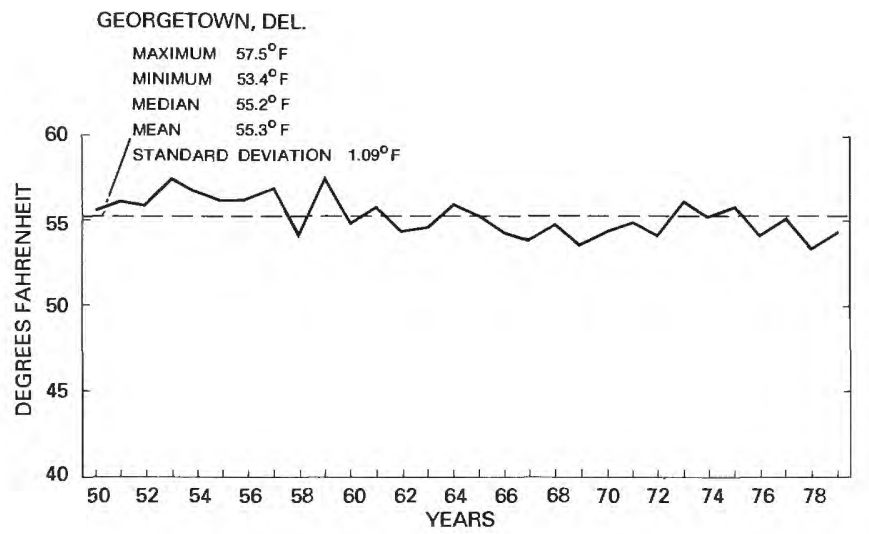

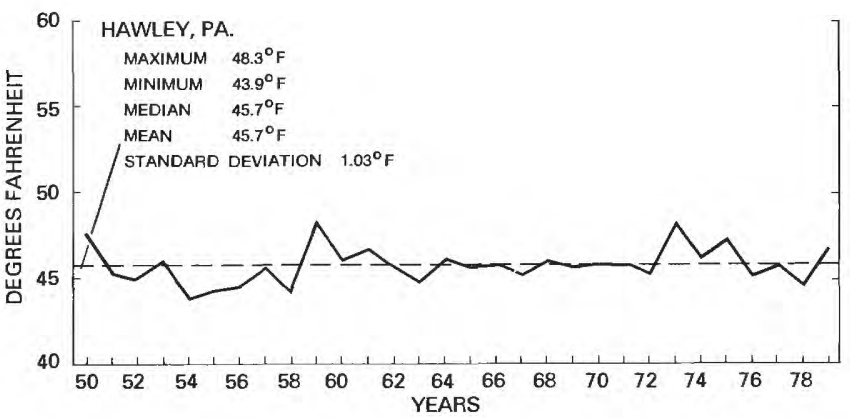
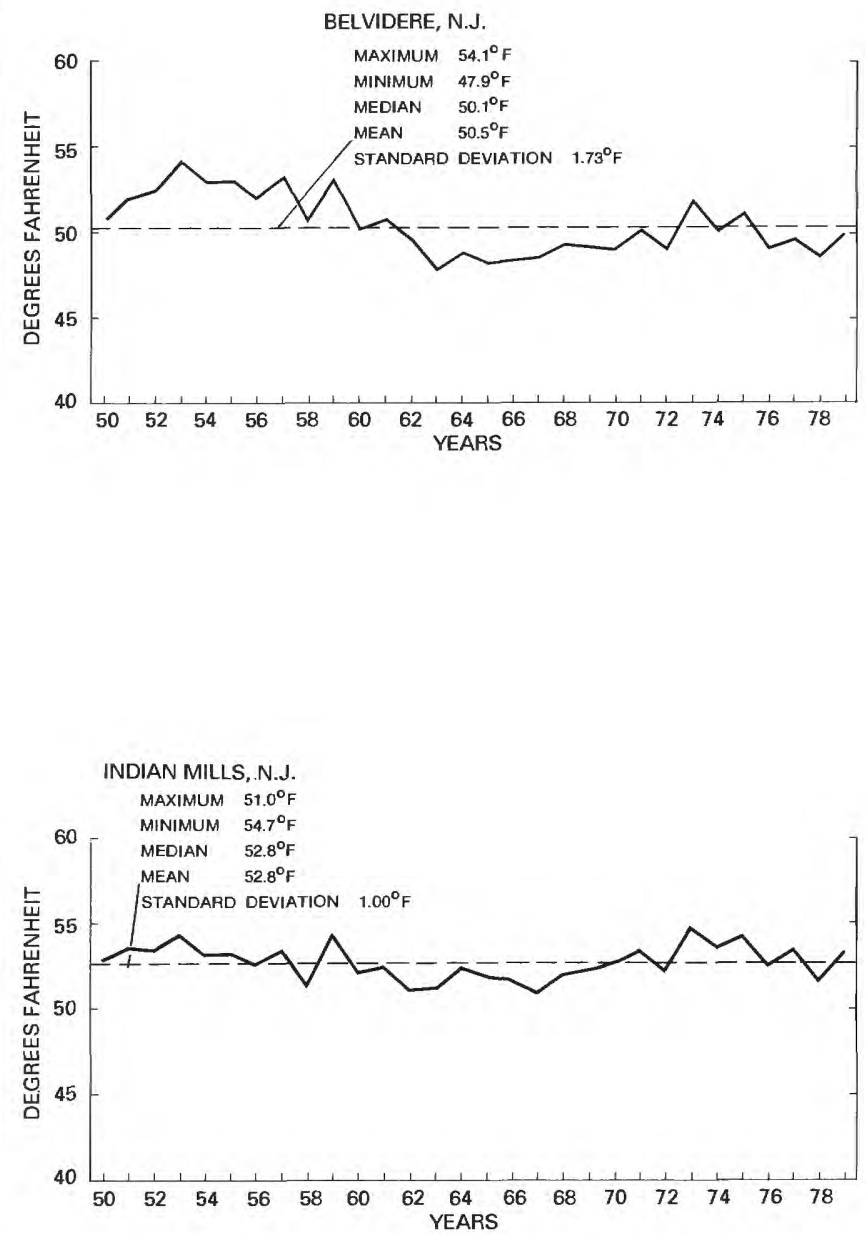

FiguRE 10 - Average annual temperature at four stations in the Delaware River basin, 1950-79. 


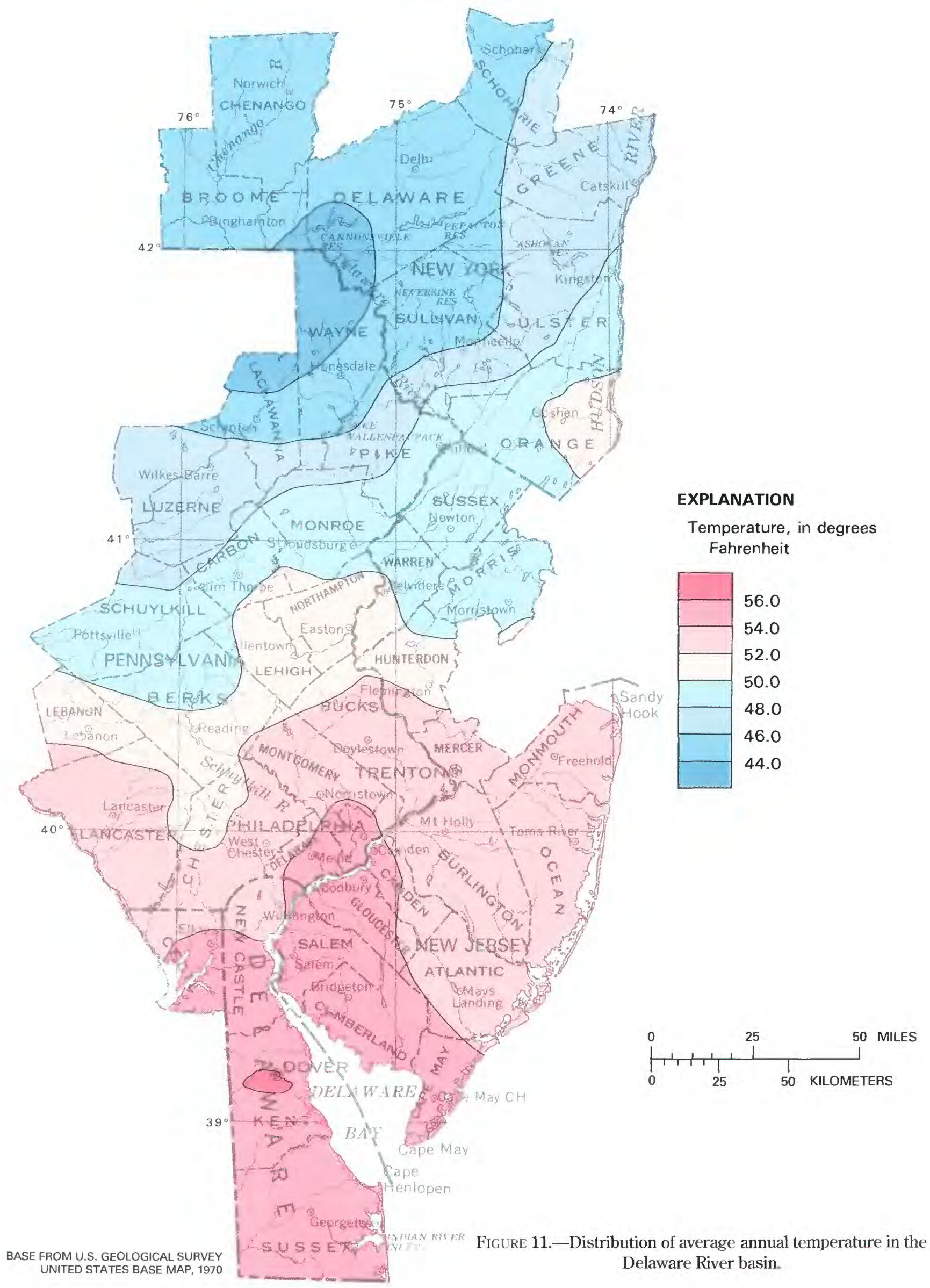


Average December Temperature

Average temperatures during December range from over $38^{\circ} \mathrm{F}$ in the south to $24^{\circ} \mathrm{F}$ at Pleasant Mount, Pa., in the north (figs. 12 and 13).

The time series plots (fig. 12) indicate a return to the high degree of year-to-year variability associated with the winter months.
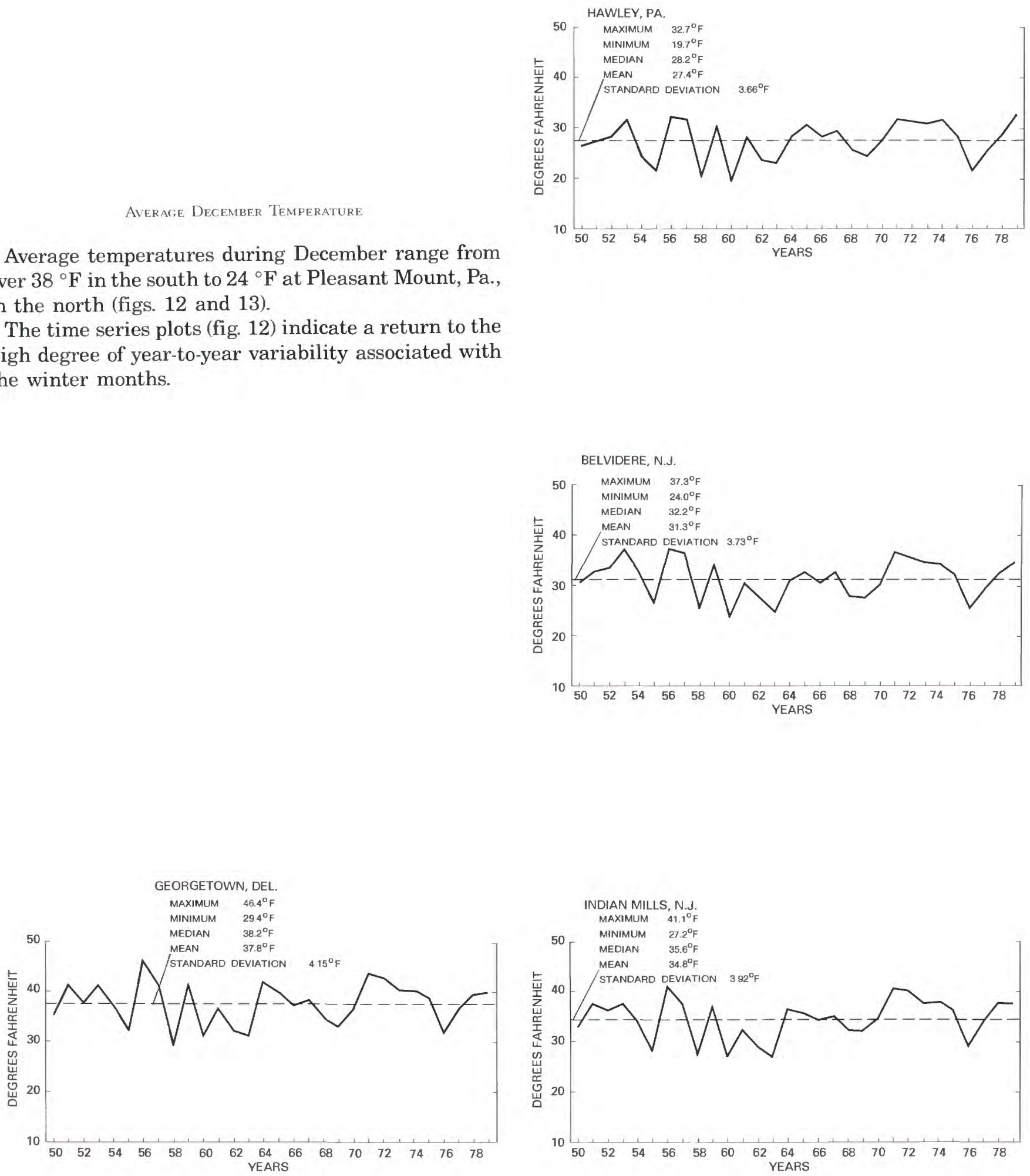

FIGURE 12.-Average December temperatures at four stations in the Delaware River basin, 1950-79. 


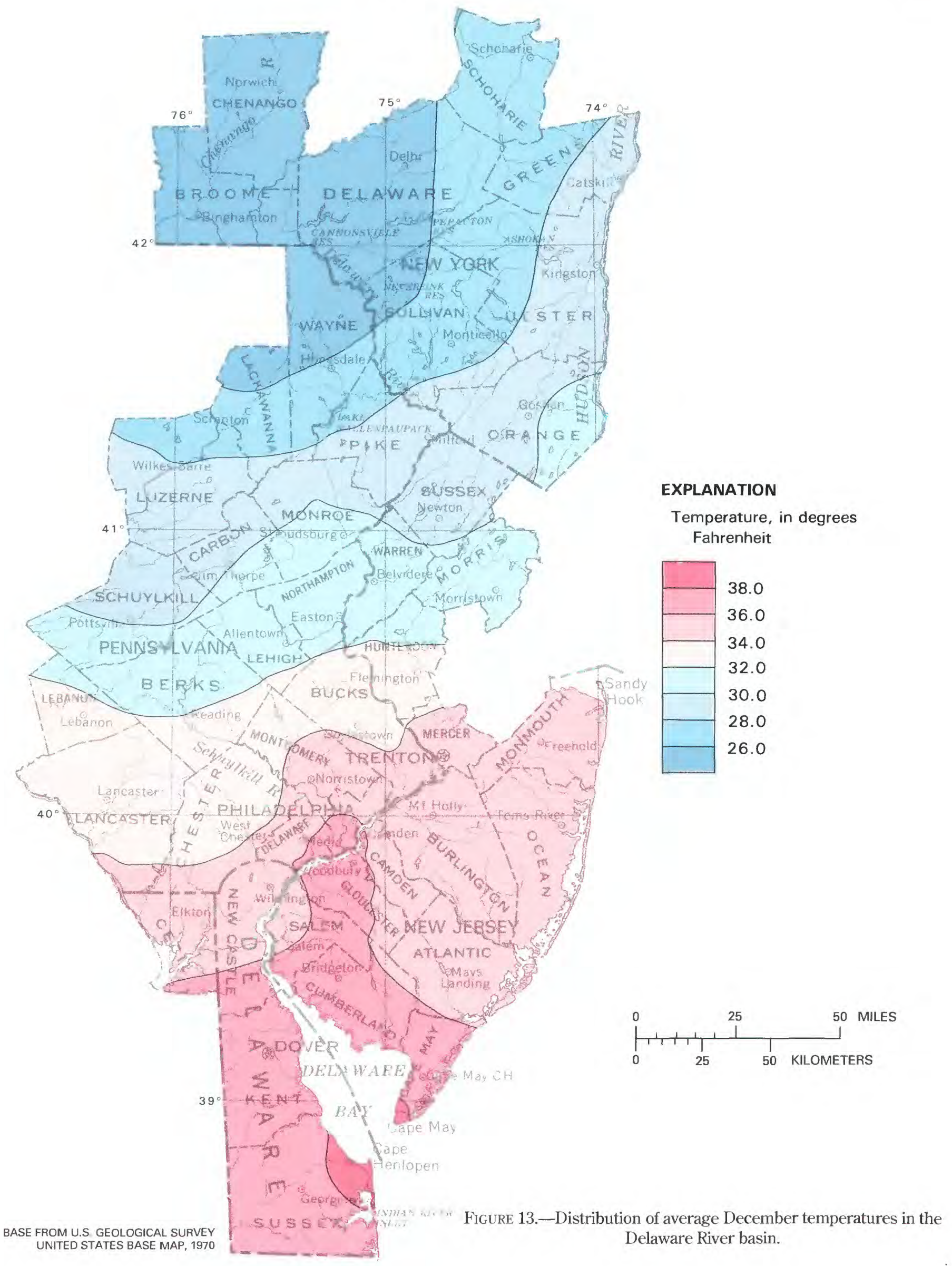




\section{Average January Temperature}

January mean temperature conditions are plotted and mapped in figures 14 and 15. A steep south-to-north temperature gradient in January mean temperature is shown in the contour map (fig. 15). Stations in the southern part of the basin average $35-36{ }^{\circ} \mathrm{F}$, and the northern stations average less than $22^{\circ} \mathrm{F}$. The heatisland effect of the Philadelphia urban area is again evident. In addition, temperature patterns in the northern half of the basin are significantly affected by the high elevations of the Catskills and the Poconos.

Time series plots of the annual values (fig. 14) provide a graphical impression of the year-to-year variability in January mean temperature. Especially noteworthy in these series are the very high average temperatures experienced at all locations in the early 1950's and the record low values of January 1977.

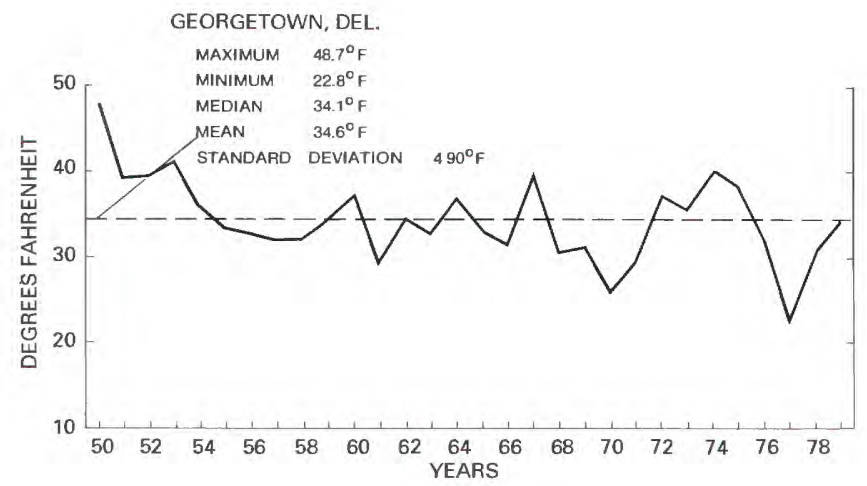

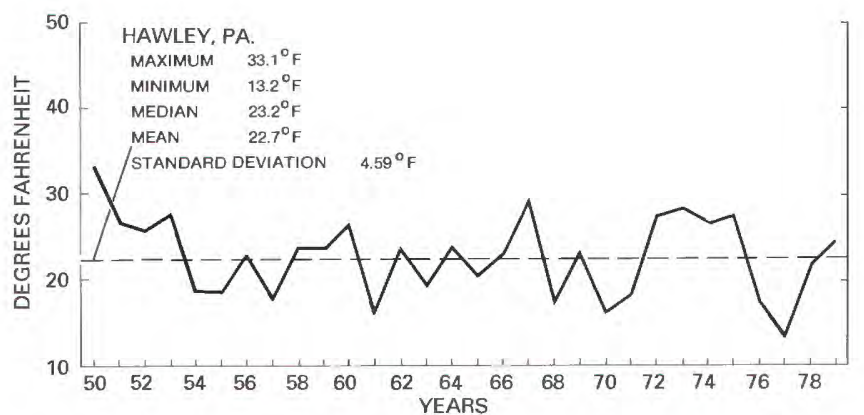
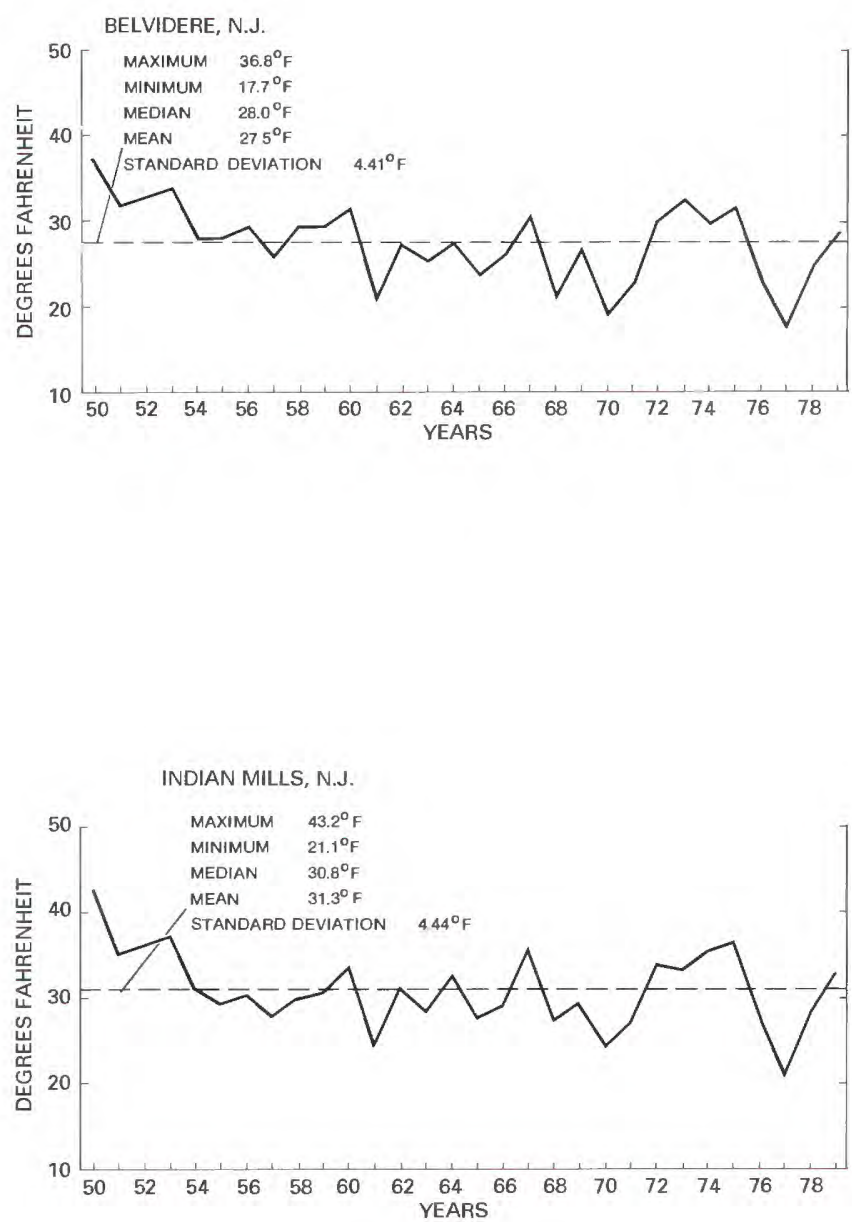

FigLRE 14.-Average January temperatures at four stations in the Delaware River basin, 1950-79. 


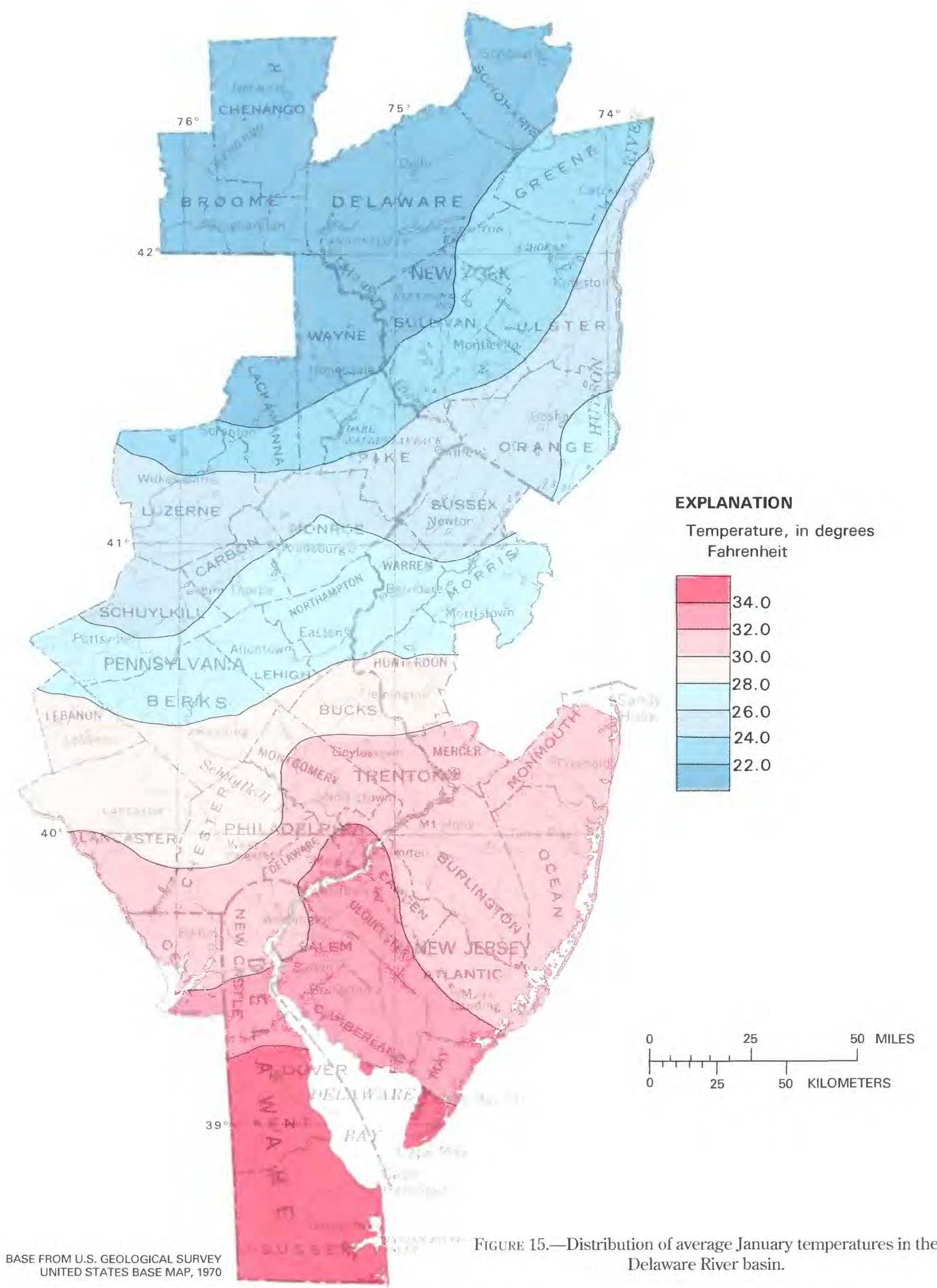


Average February Temperature

The month of February shows the greatest range in average temperatures throughout the basin (figs. 16 and 17). Southern Delaware stations average $35-37^{\circ} \mathrm{F}$, and the northern stations show average temperature less than $22^{\circ} \mathrm{F}$. The urban influence at Philadelphia is marked.

Annual time series plots (see fig. 16) show a series of warm Februaries in the early 1950's and particularly cold temperatures in 1978 and 1979.
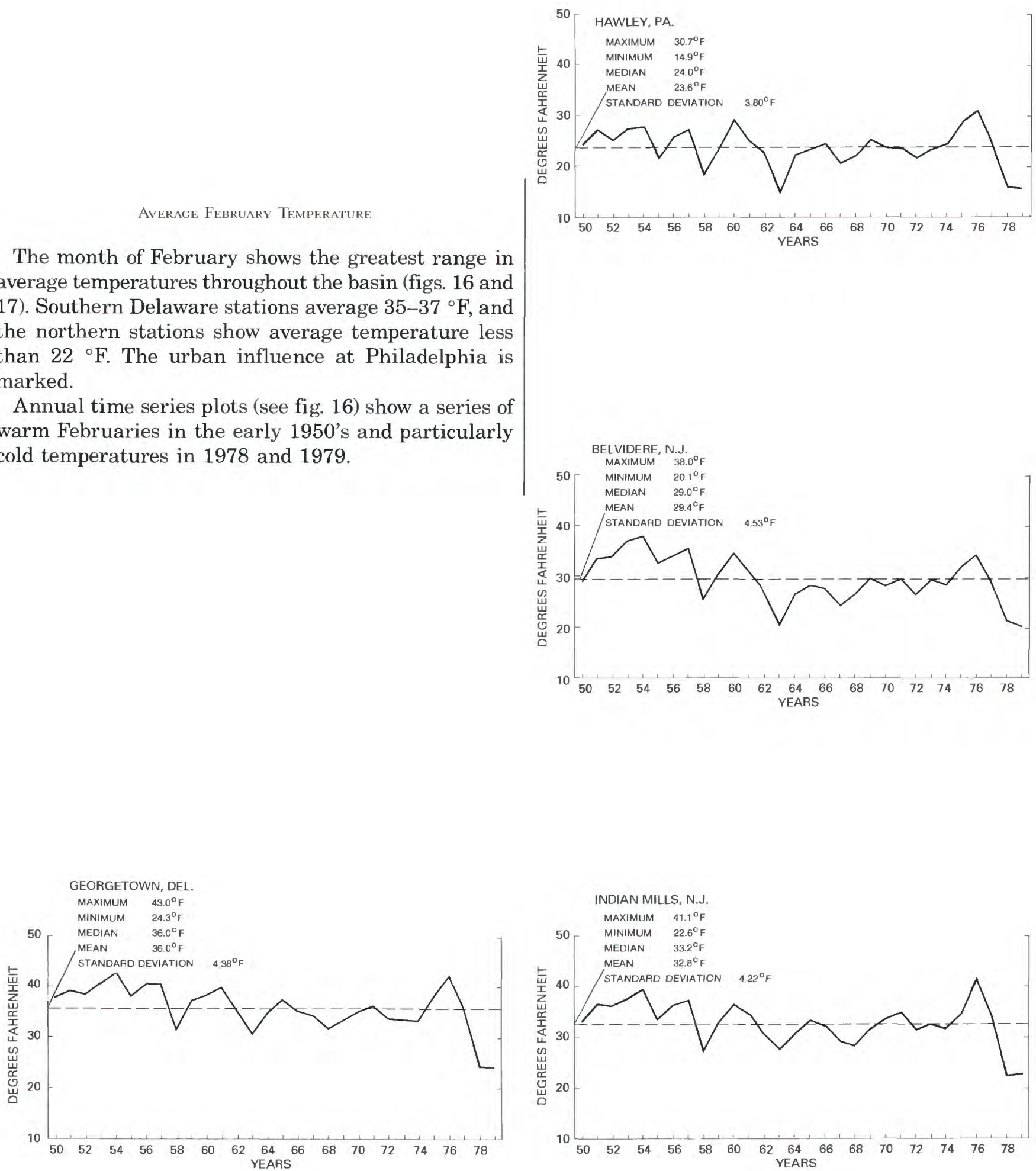

Figure 16.-Average February temperatures at four stations in the Delaware River basin, 1950-79. 


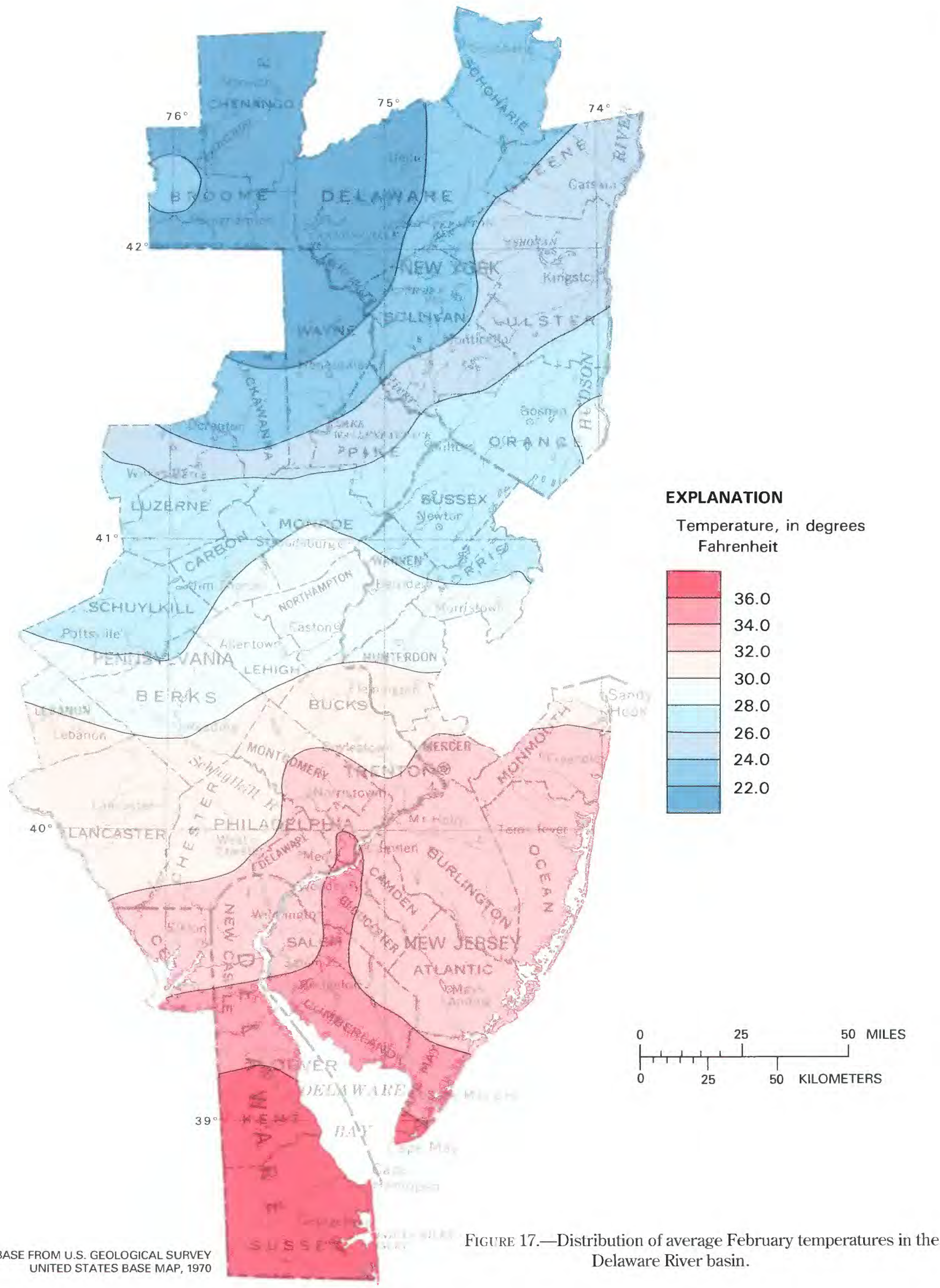




\section{Average. March Temperature}

The range in average temperature over the Delaware River basin in March is from values below $32{ }^{\circ} \mathrm{F}$ in the northern counties to values in the $42-44^{\circ} \mathrm{F}$ range in the south (figs. 18 and 19). The lowest average March temperature is $29.0^{\circ} \mathrm{F}$ at Pleasant Mount, $\mathrm{Pa}$.; the highest average temperatures of $44.2^{\circ} \mathrm{F}$ are at Milford and Dover, Del.

Time series plots are shown in figure 18. The month of March 1960 was particularly cool at all four of the transect stations as well as over most of the United States east of the Rockies. This was a result of the development and persistence of a particularly deep trough along the East Coast. An unusually strong northerly flow was associated with this trough and the entire Eastern United States was dominated by a persistently cold air mass (Dunn, 1960).
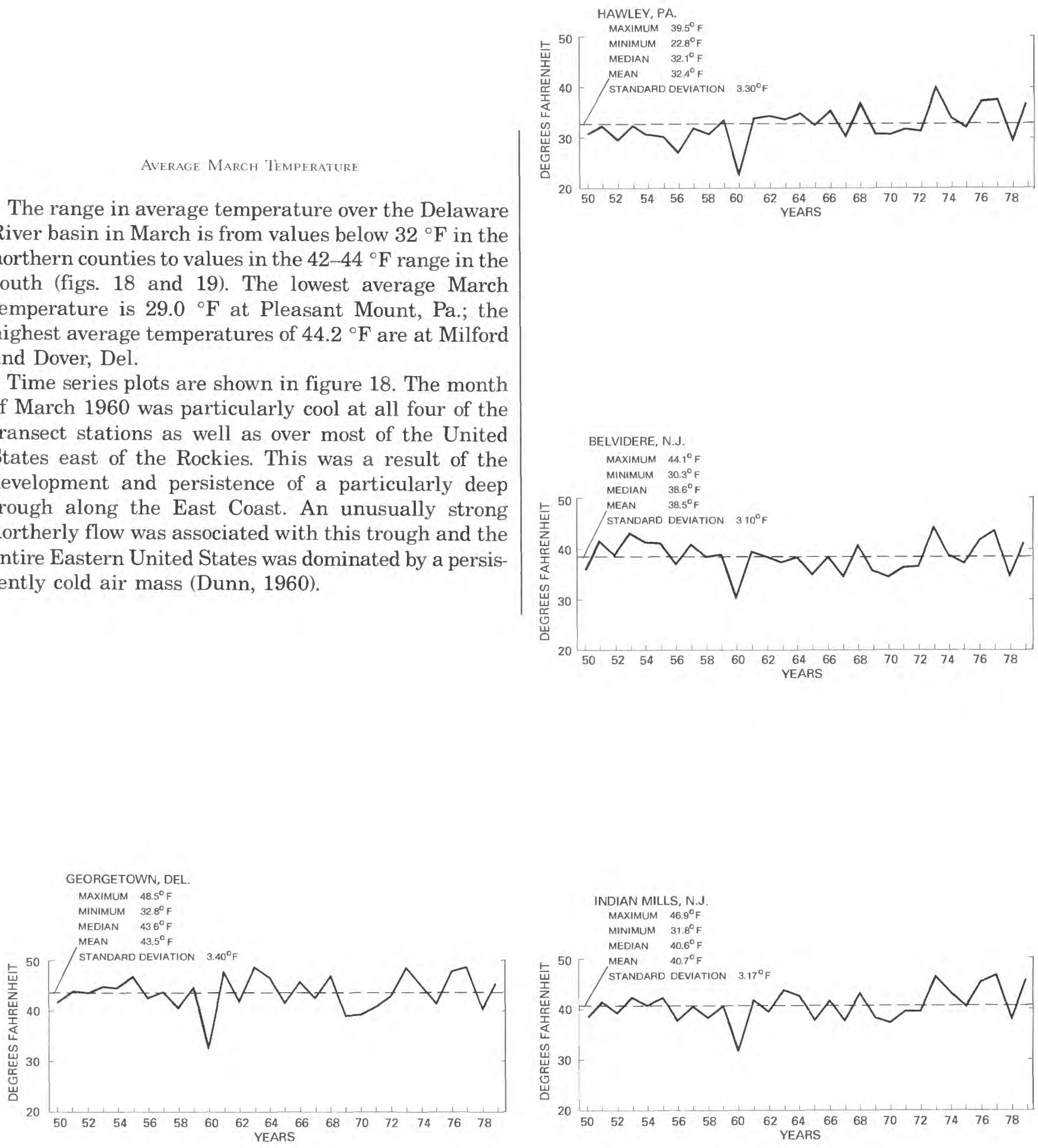

FIGURE 18.-Average March temperature at four stations in the Delaware River basin, 1950-79. 


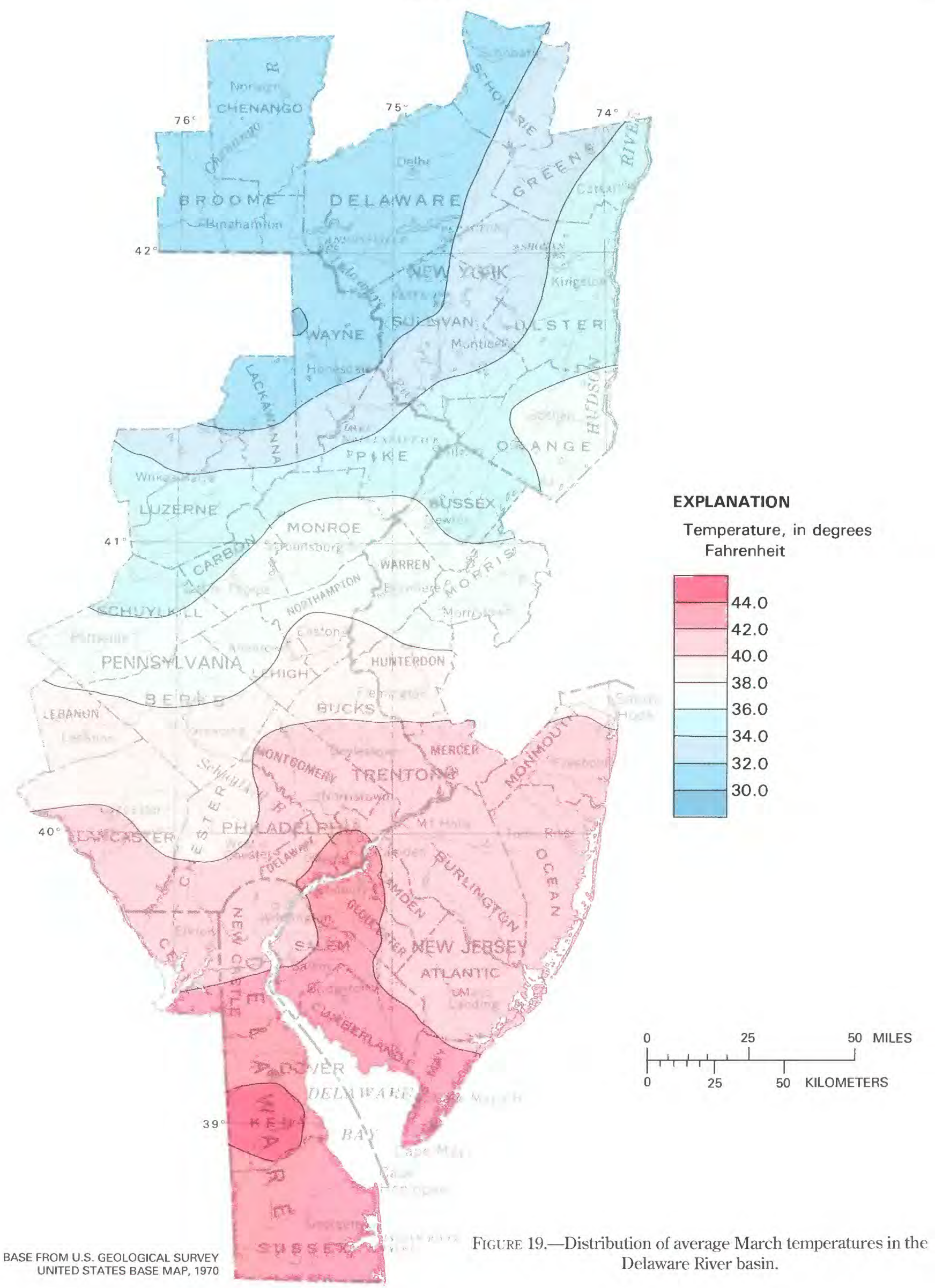


Average April Temperature

As the hemispheric temperature gradient weakens, so does the contrast in temperatures along the north-south axis of the Delaware River basin. April average temperatures range from greater than $54^{\circ} \mathrm{F}$ in the south to less than $44{ }^{\circ} \mathrm{F}$ in the northern areas (figs. 20 and 21). Urban effects are evident in the Philadelphia area.

Time series plots for April are shown in figure 20.

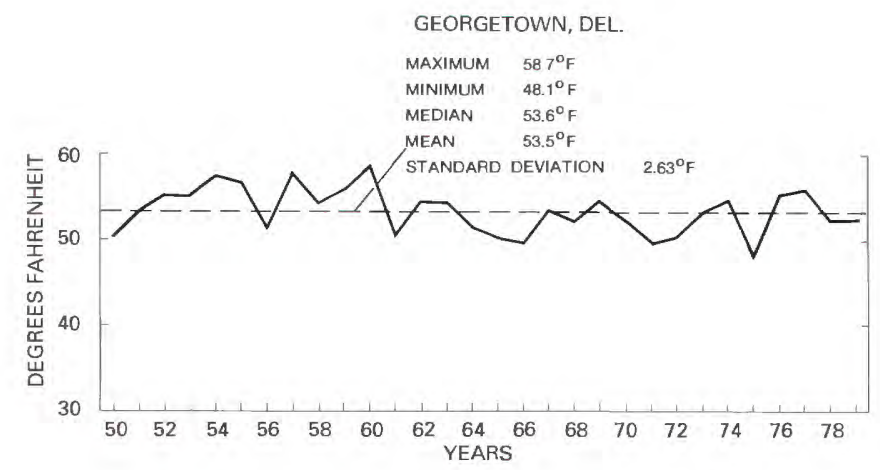

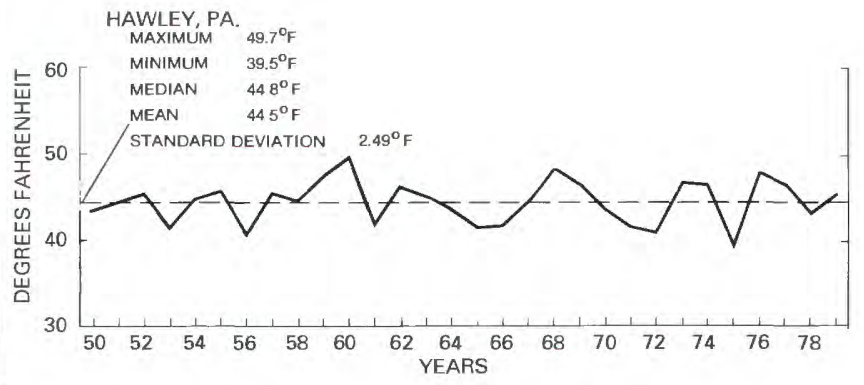
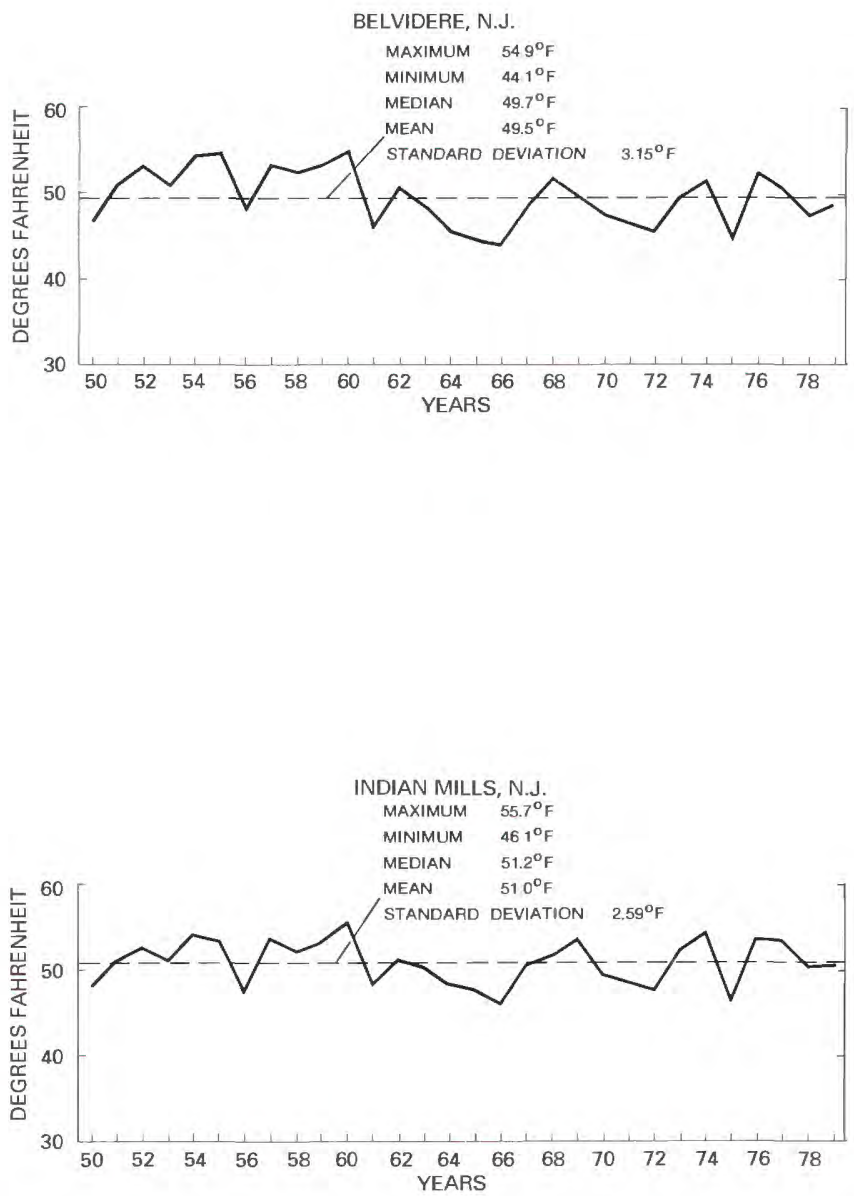

FigurE 20.-Average April temperatures at four stations in the Delaware River basin, 1950-79. 


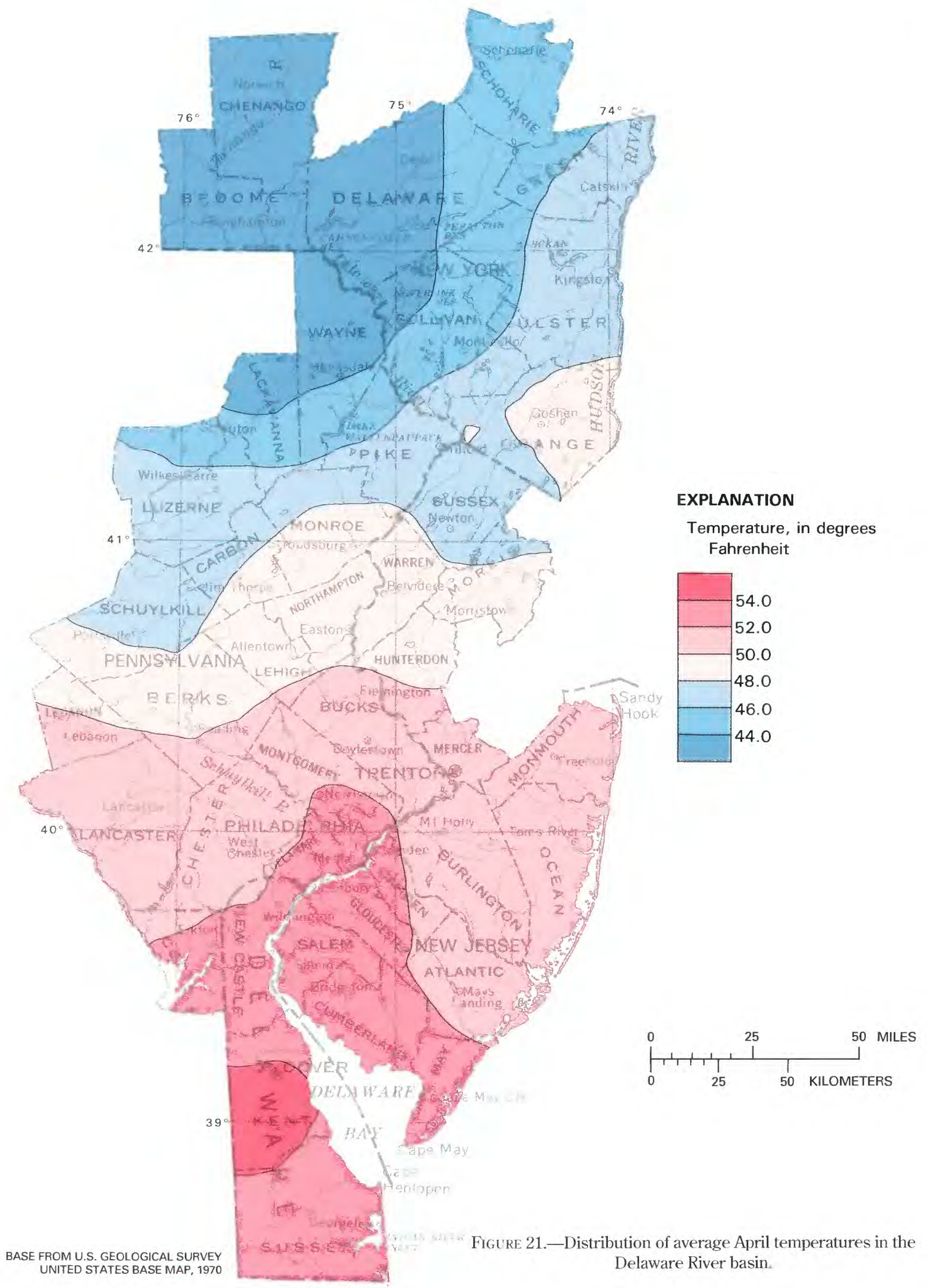


Average May Temperature

May average temperatures range from less than $54{ }^{\circ} \mathrm{F}$ to over $62^{\circ} \mathrm{F}$ depending on latitude (figs. 22 and 23). The Philadelphia urban heat-island effect is apparent.

Particularly low May average temperatures occurred at all stations in 1967. An unusually deep trough was situated along the eastern seaboard during the first half of that month. Associated with it was a strong northerly flow component that resulted in relatively cool temperatures along the east coast. Trenton, N.J., in the Delaware basin, experienced the coldest May since 1917 (Stark, 1967).

Time series plots for May are shown in figure 22 .

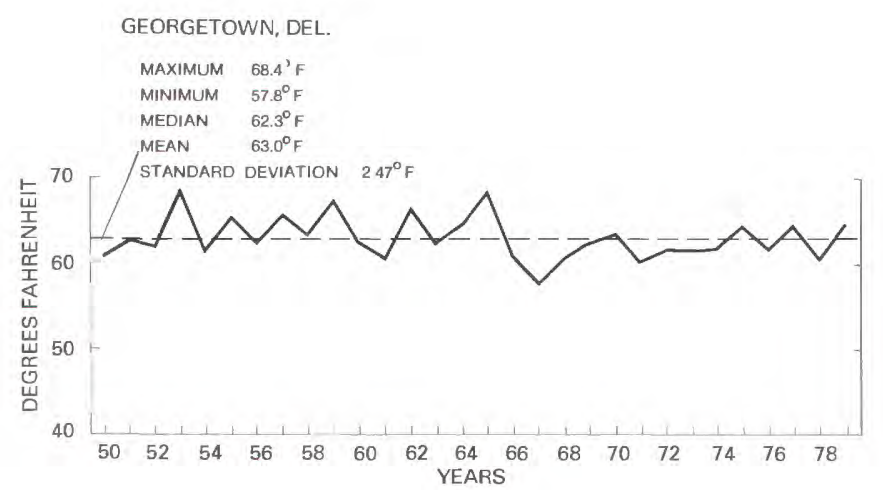

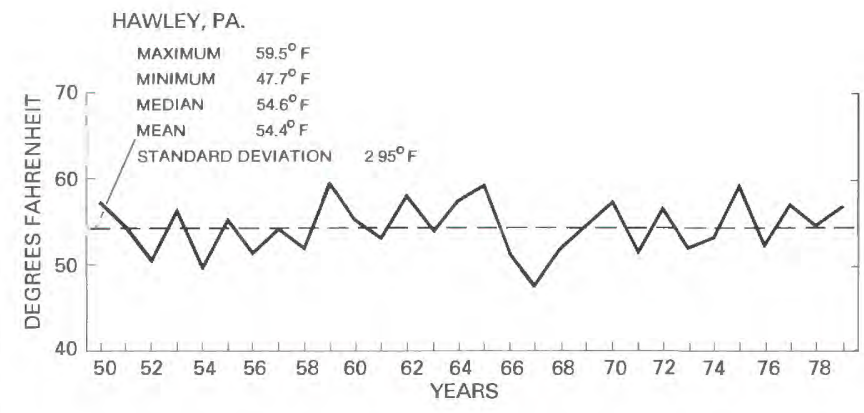
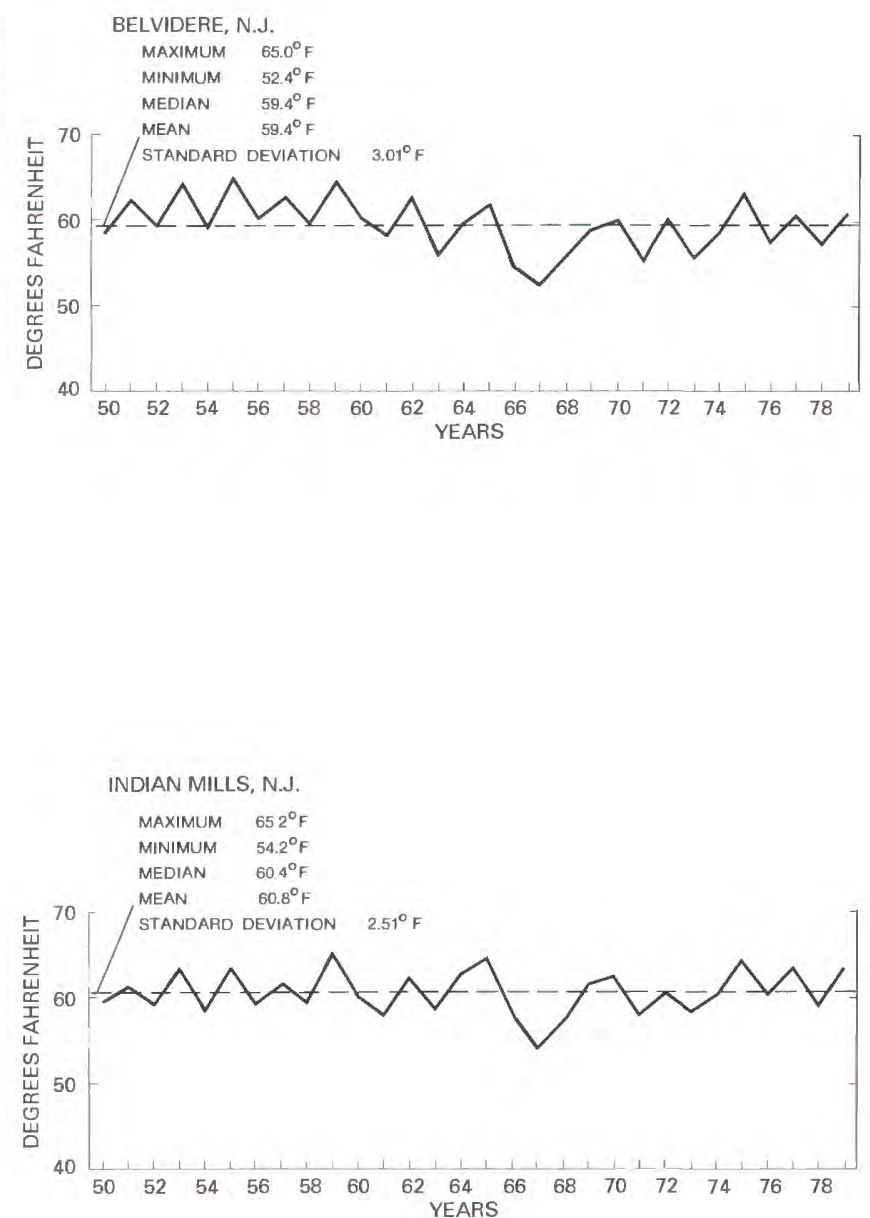

FIGURE 22.-Average May temperatures at four stations in the Delaware River basin, 1950-79. 


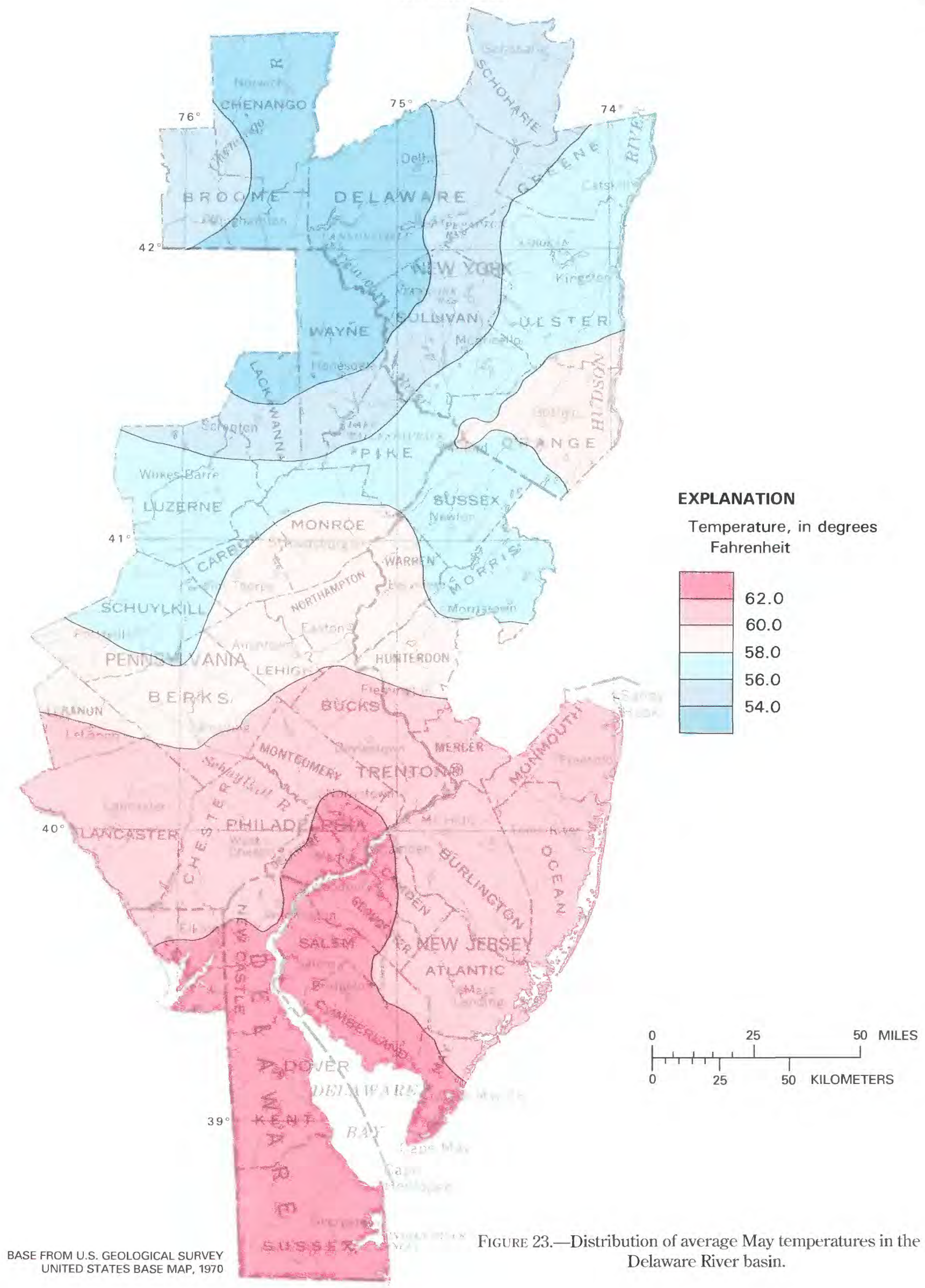




\section{Average June Temperature}

In June, average temperatures in the Delaware River basin range from less than $63^{\circ} \mathrm{F}$ to over $72^{\circ} \mathrm{F}$. (figs. 24 and 25).

Time series plots (fig. 24) indicate low year-to-year variability during the 1960 's at the two stations in the southern part of the basin, Georgetown, Del., and Indian Mills, N.J.
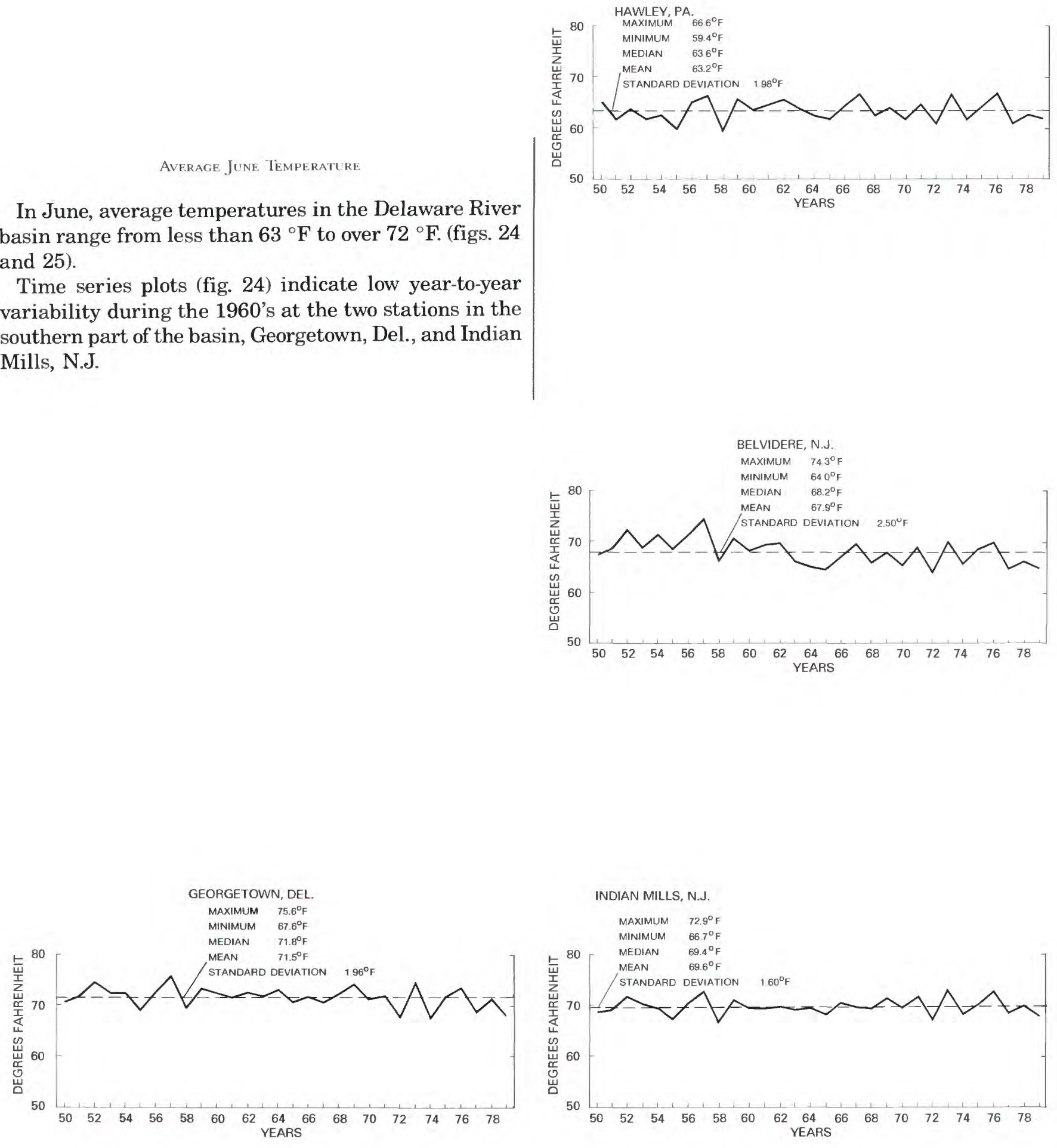

FiguRE 24.-Average June temperature at four stations in the Delaware River basin, 1950-79. 


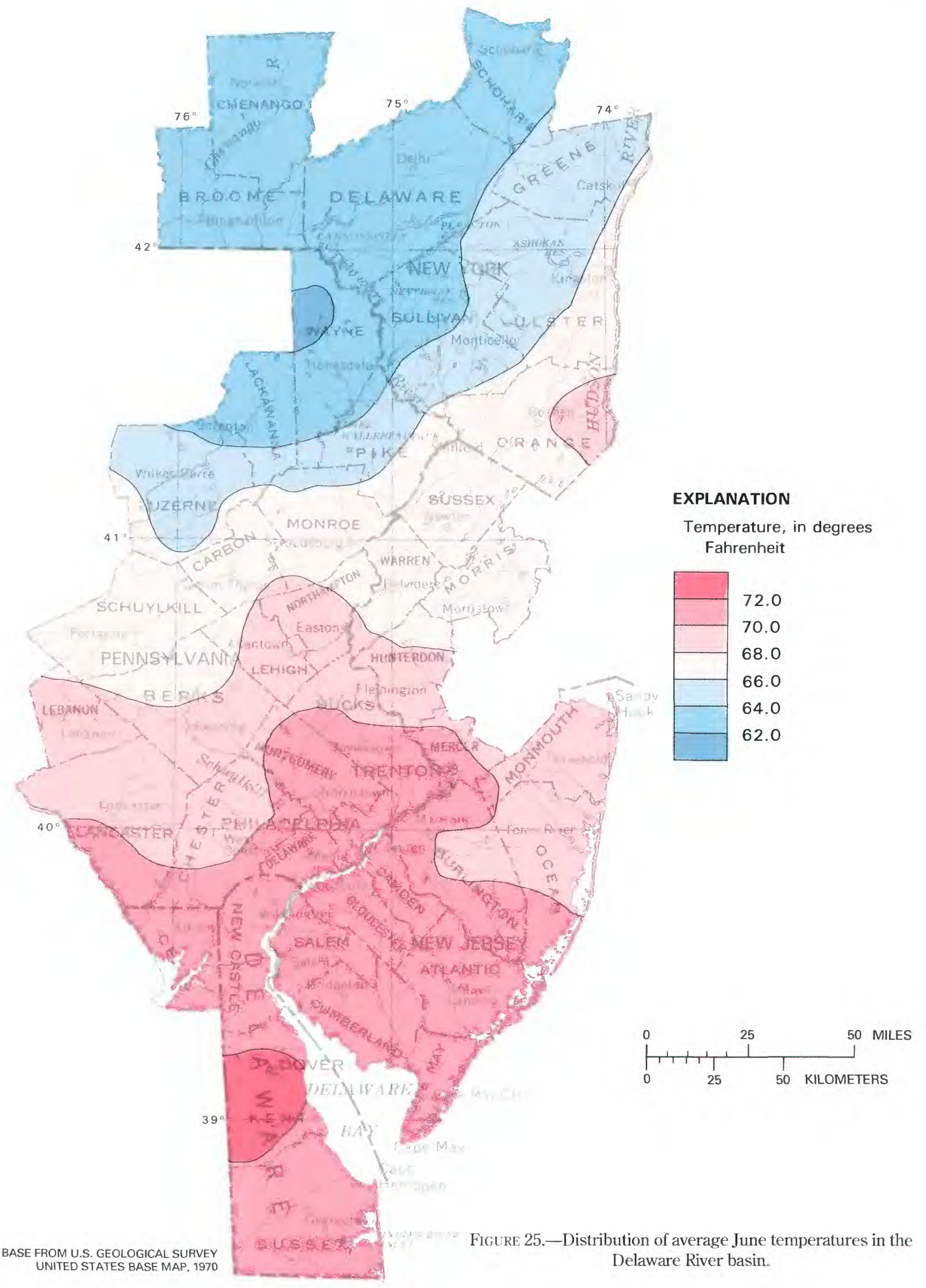




\section{AVERAge July Temperatire}

July is the month associated with the mildest latitudinal temperature gradient over the Northern Hemisphere and within the Delaware River basin (figs. 26 and 27). The highest average temperature is 77.7 ${ }^{\circ} \mathrm{F}$ at Marcus Hook, Pa., a station within the Philadelphia metropolitan area; coolest average temperatures occurred at Pleasant Mount, Pa., with a mean July temperature for the 30-year period of $65.1^{\circ} \mathrm{F}$.

Time series plots (fig. 26) indicate low year-to-year variability when compared with those of winter months.
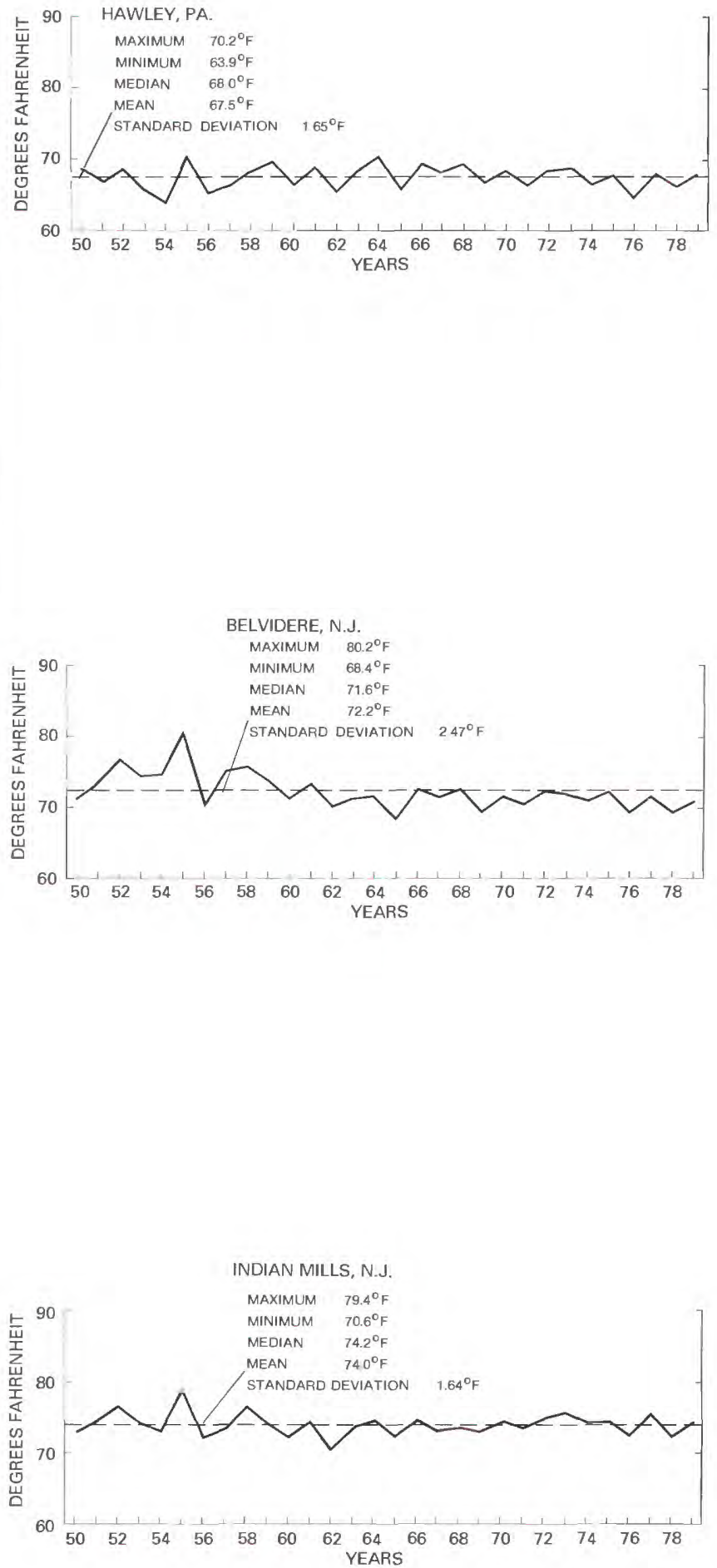

FIGt'RE 26.-Average July temperatures at four stations in the Delaware River basin, 1950-79. 


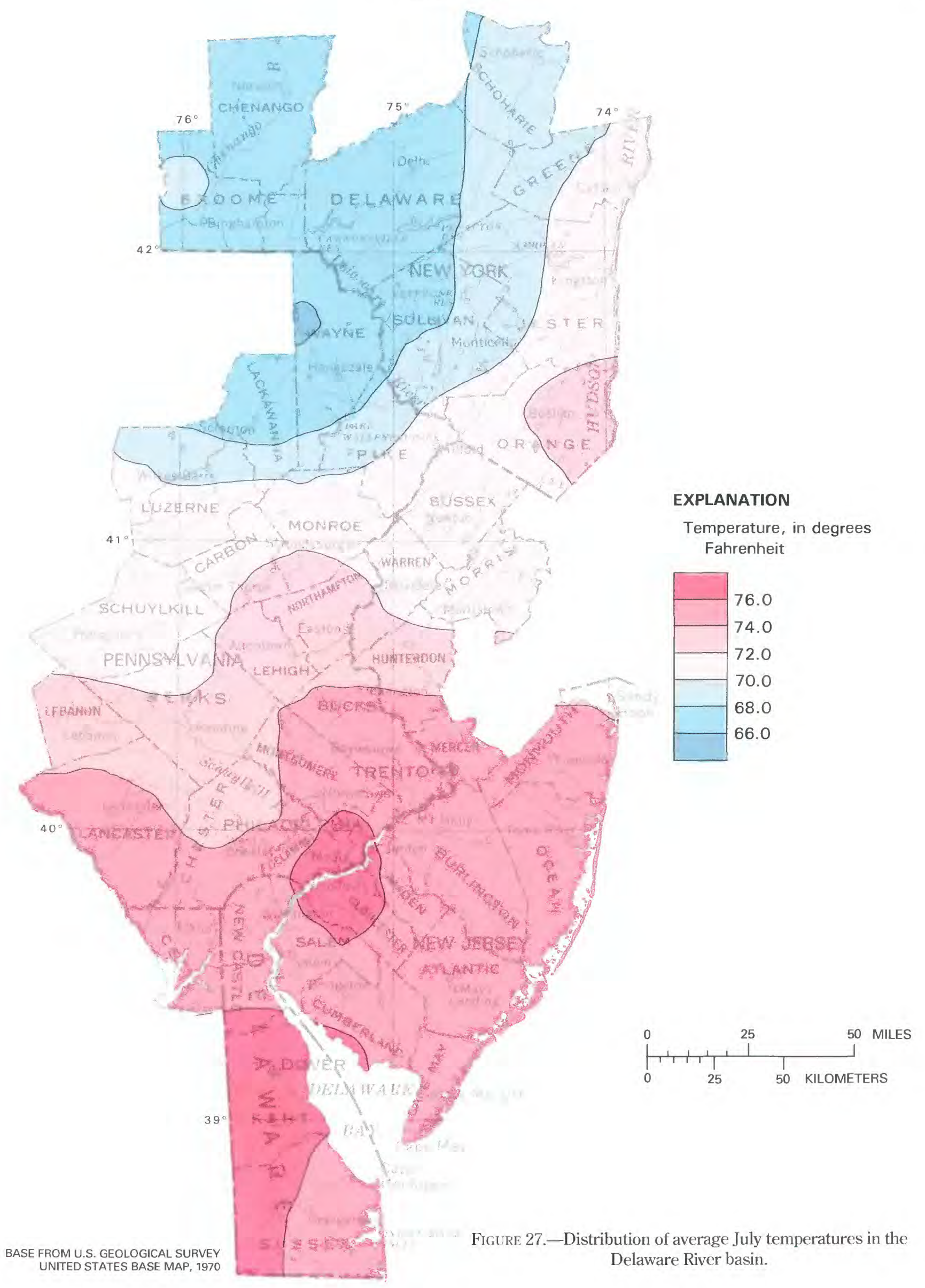


The weak temperature gradient of July continues than $66{ }^{\circ} \mathrm{F}$ in the north to over $74{ }^{\circ} \mathrm{F}$ in the south (figs. 28 and 29).

Again, the time series plots (fig. 28) indicate relatively low year-to-year variability in average August temperatures. through August. Average temperatures range from less
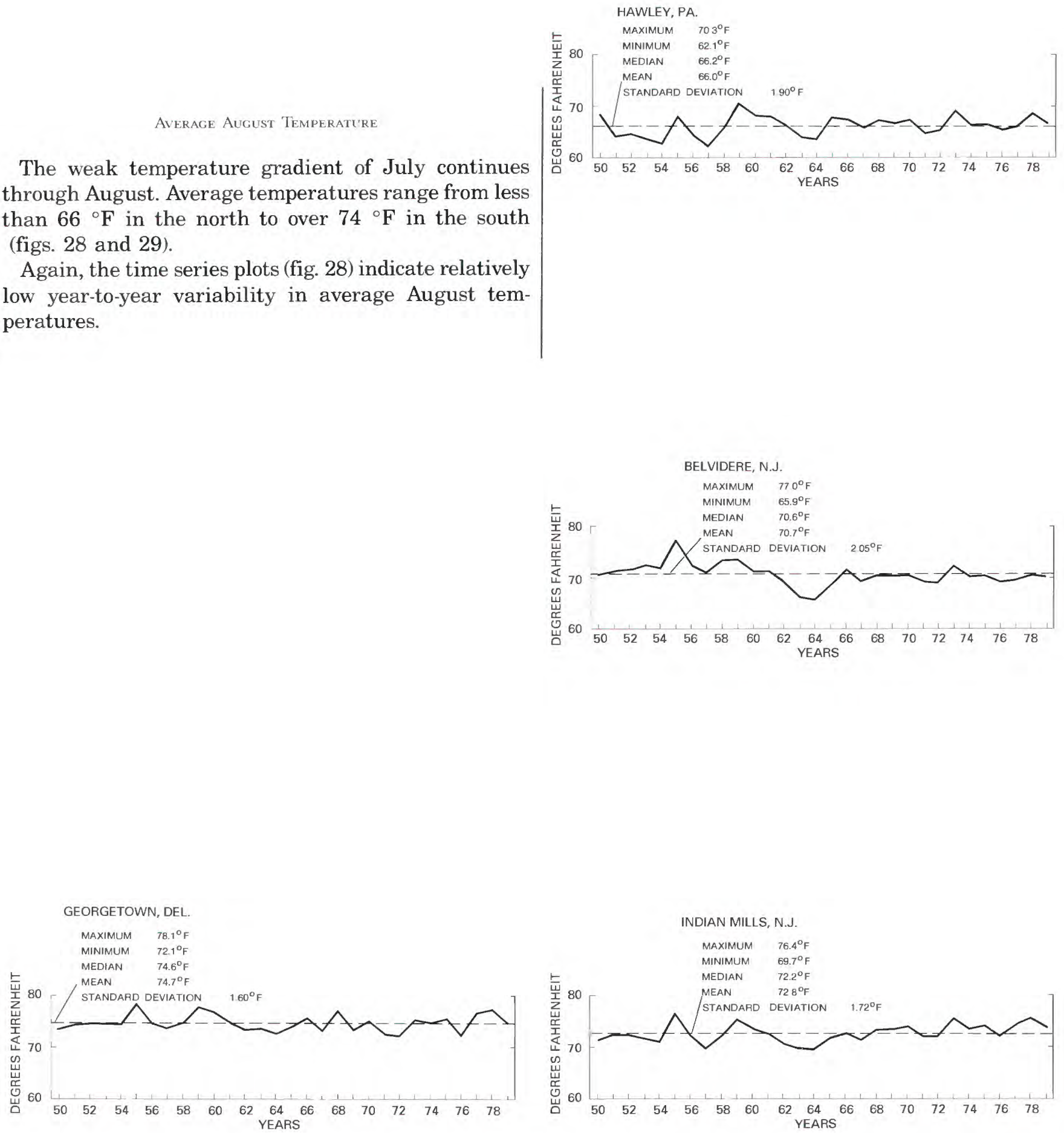

FiguRE 28.-Average August temperatures at four stations in the Delaware River basin, 1950-79. 


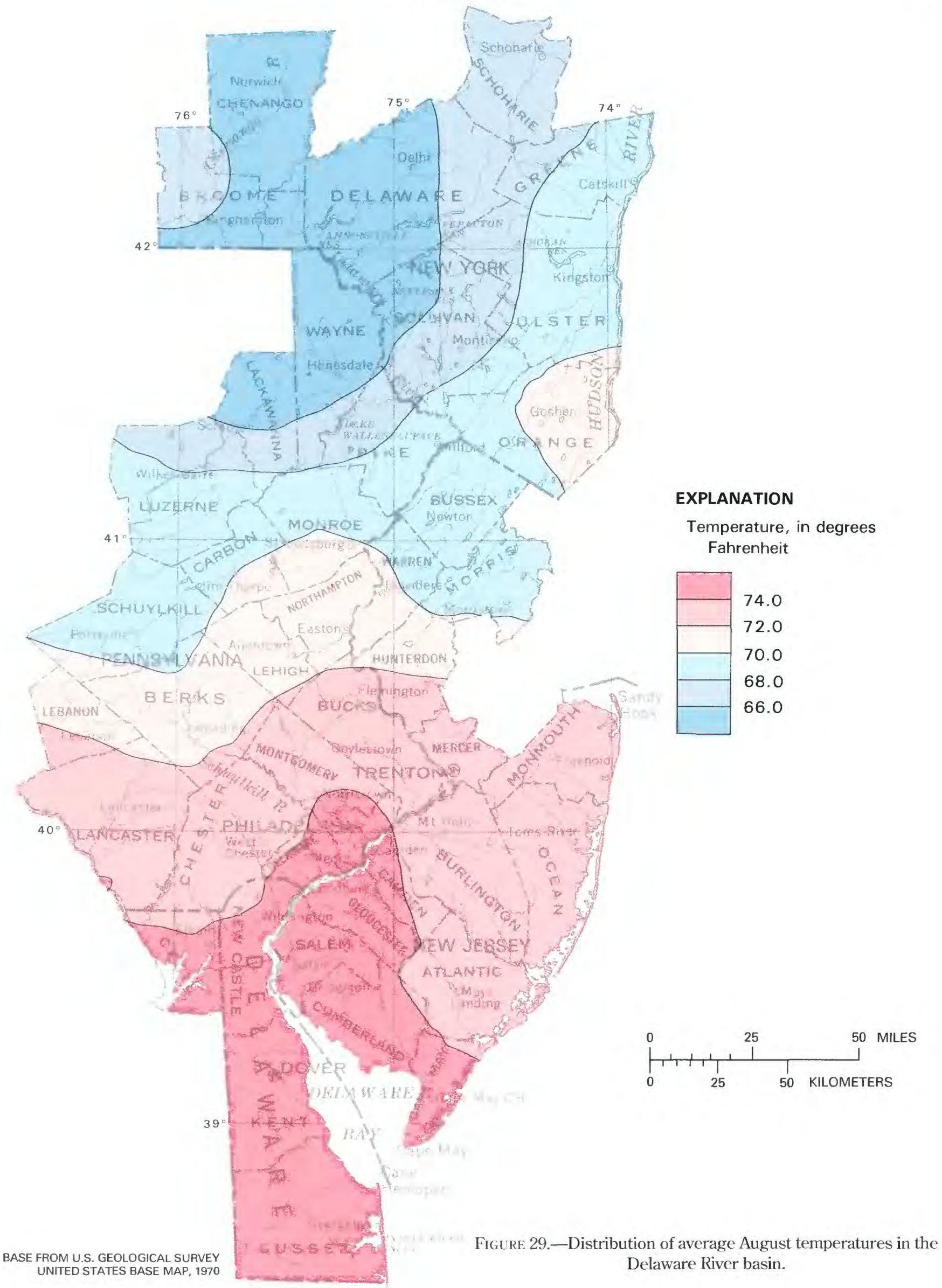


Average September Temperature

Pleasant Mount, Pa., has the lowest average September temperature in the basin at $56.4^{\circ} \mathrm{F}$. Highest averages are shared by Dover, Del., and Drexel Institute in Philadelphia at slightly over $69{ }^{\circ} \mathrm{F}$ (figs. 30 and 31). The Philadelphia heat island is apparent on the September average temperature map.

Time series plots for September are shown in figure 30 .
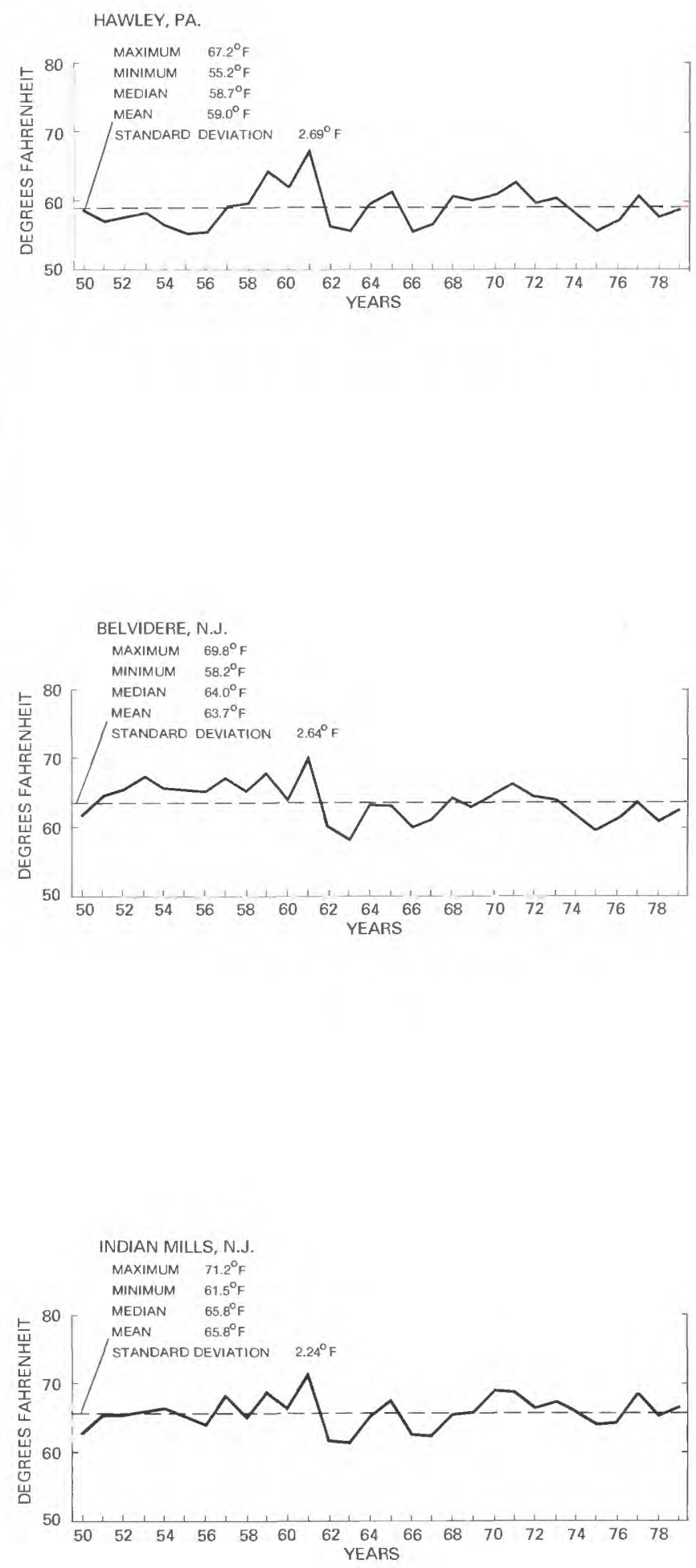

FigiliRE 30.-Average September temperatures at four stations in the Delaware River basin, 1950-79. 


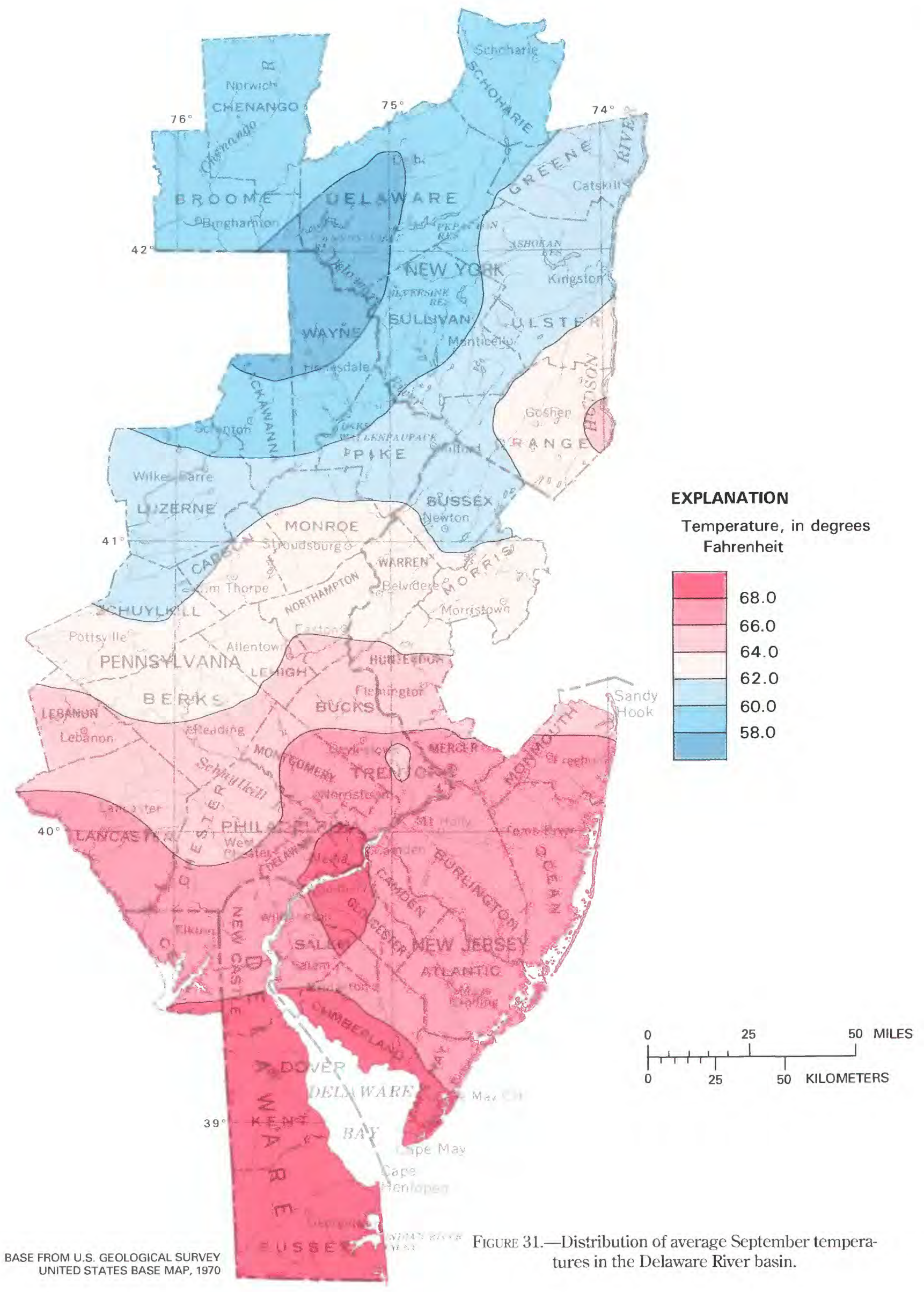


Average October Temperature

October average temperatures range from over $58^{\circ} \mathrm{F}$ at Dover, Del., and at Drexel Institute to $43.3^{\circ} \mathrm{F}$ at Pleasant Mount, Pa., in the north (figs. 32 and 33). The urban effect of Philadelphia is apparent.

Time series plots for October are shown in figure 32.
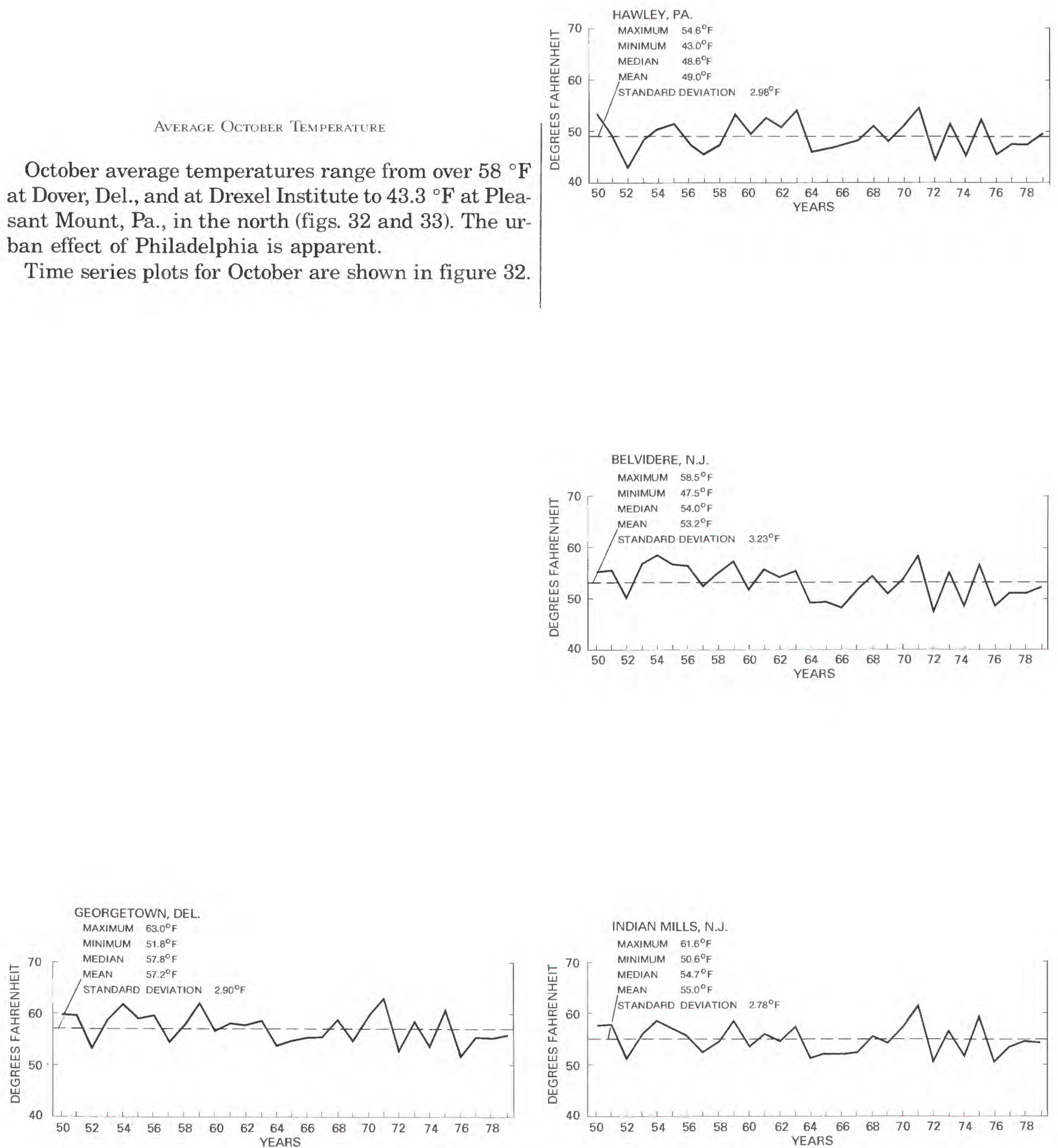

FiguRE 32.-Average October temperatures at four stations in the Delaware River basin, 1950-79. 


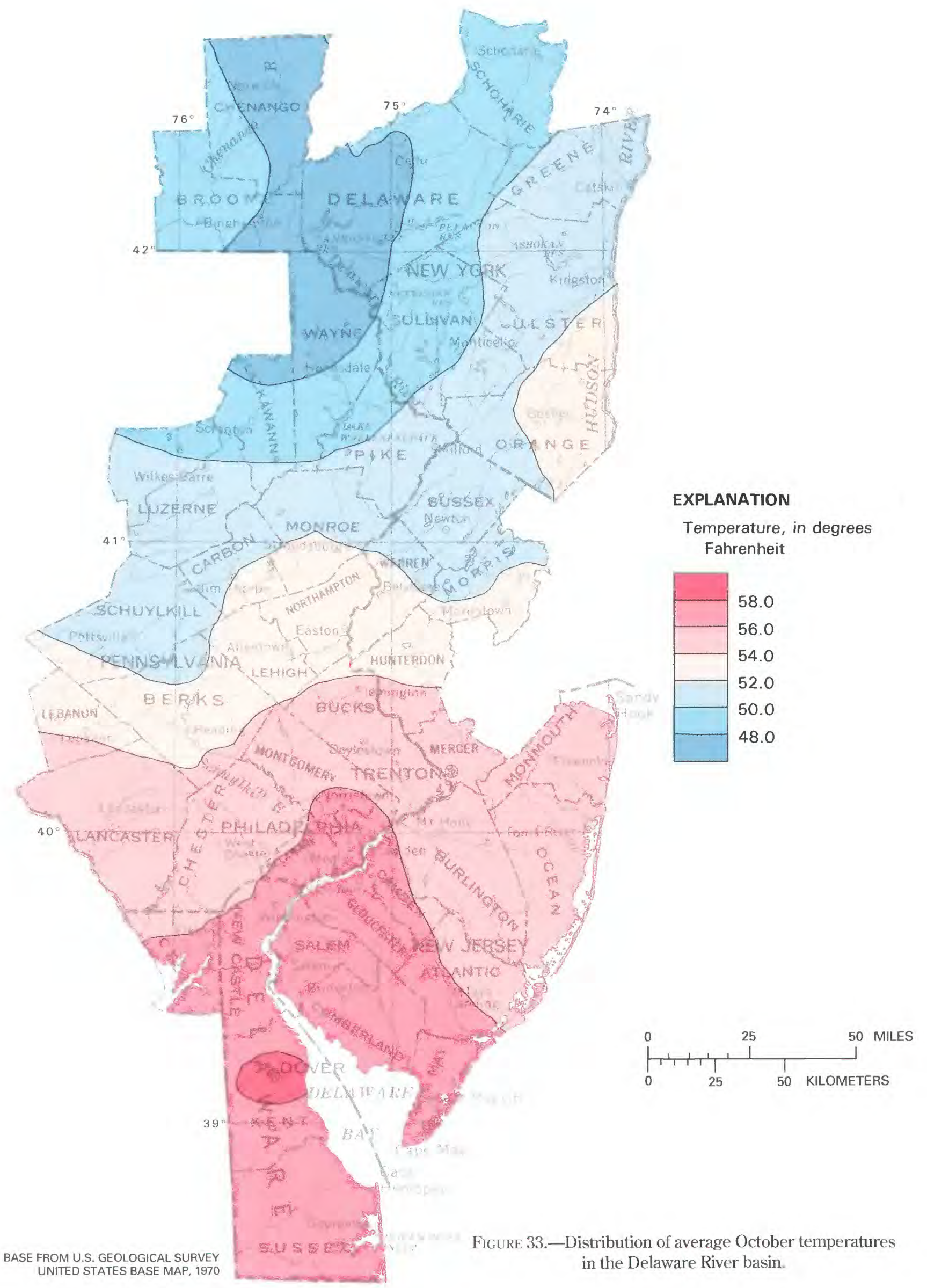


Average November Temperatire

Average temperatures in November range from 46-48 ${ }^{\circ} \mathrm{F}$ in the south to $36-38^{\circ} \mathrm{F}$ in the north (figs. 34 and 35 ). The month of November 1976 averaged well below the 1950-79 mean November temperature value at all stations. As in situations previously described, this was related to an unusually deep East Coast trough that resulted in advection of cold air from high latitudes into the Eastern United States (Dickson, 1977).

Time series plots for November are shown in figure 34 .
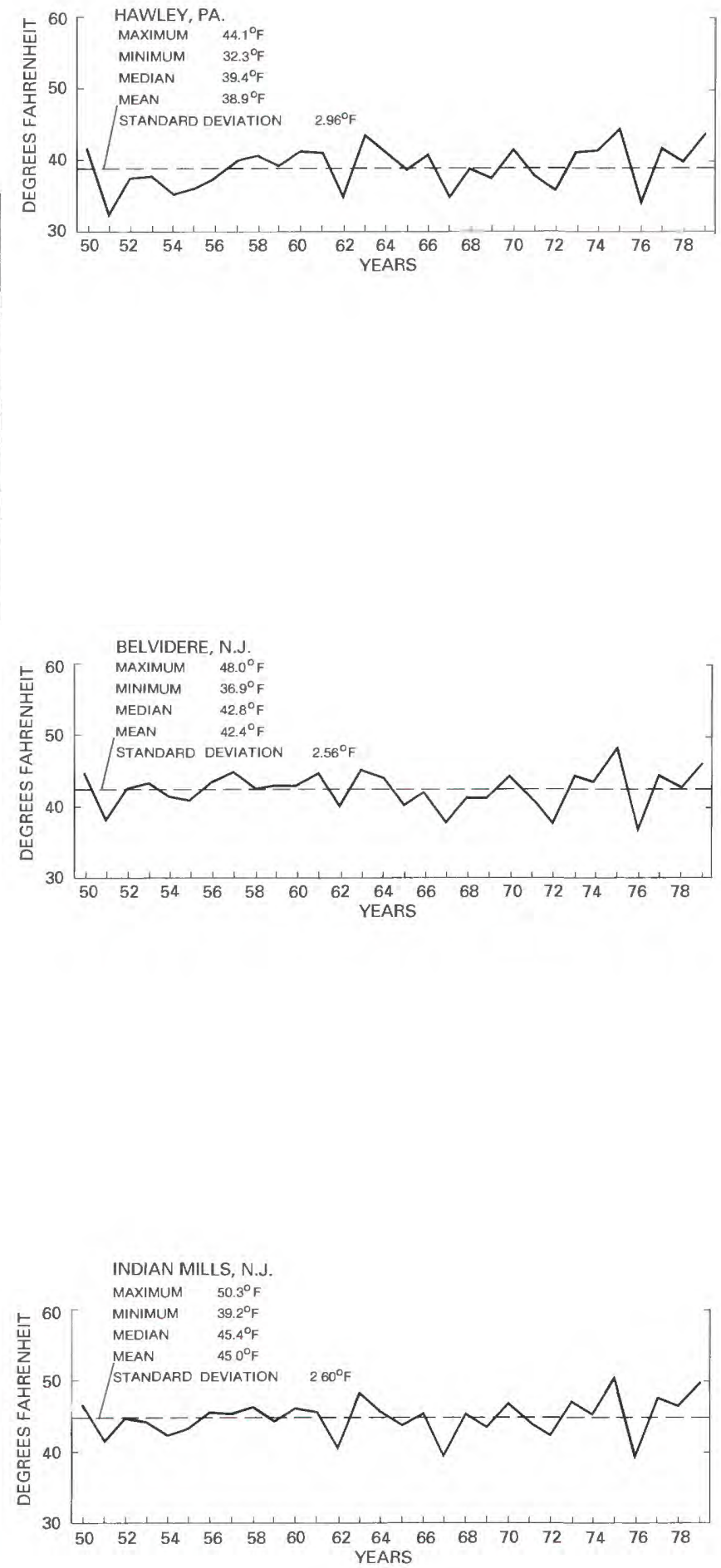

FIGURE 34.-Average November temperatures at four stations in the Delaware River basin, 1950-79. 


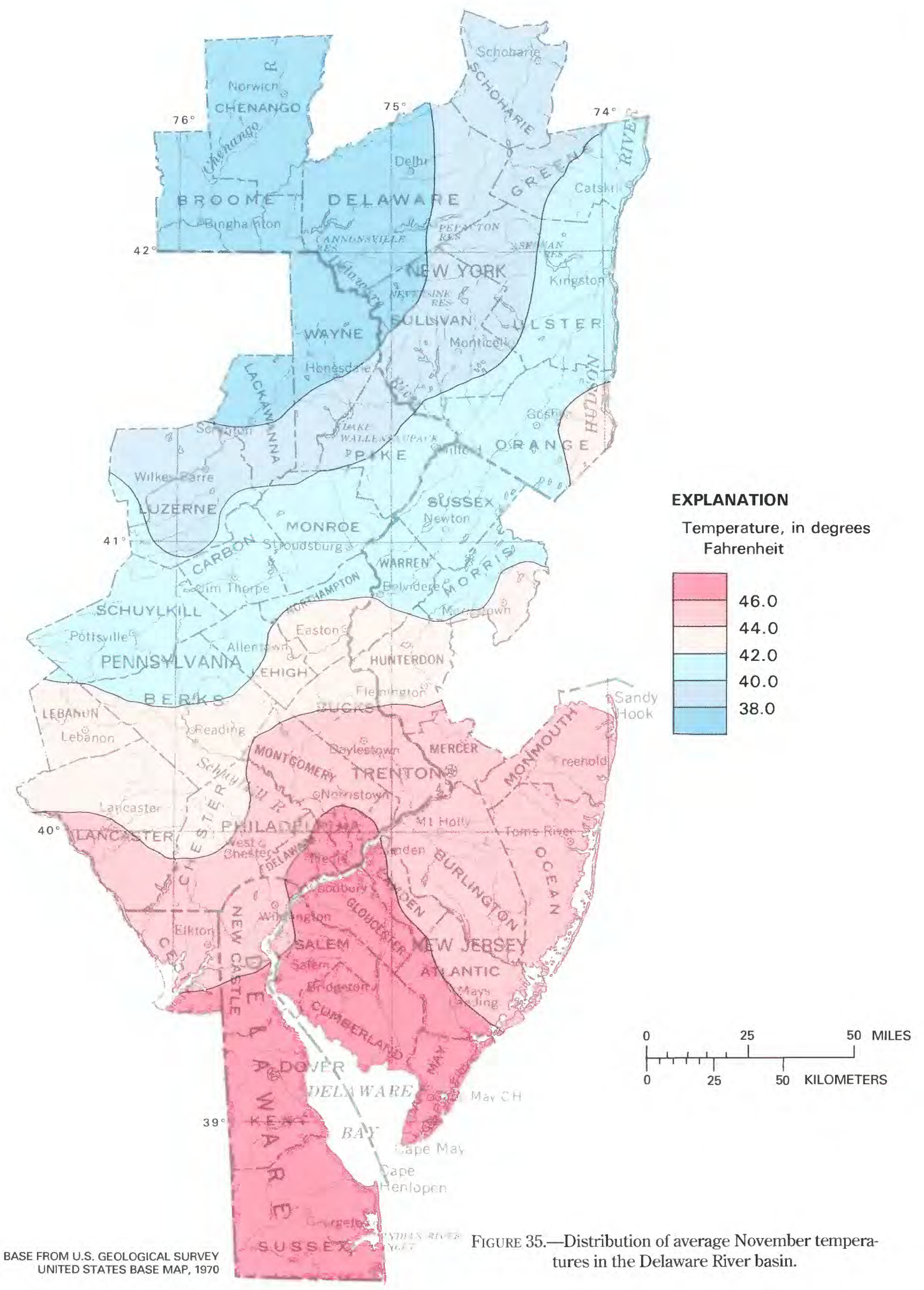




\section{AVERAGE WINTER TEMPERATURE}

Average temperatures for the winter season are plotted and mapped in figures 36 and 37. The map of average December-February temperatures is a composite of the individual monthly maps (fig. 37). In the southern half of the basin, the latitudinal decrease in average temperature is evident as is the Philadelphia urban heat-island effect. In the northern part of the basin, elevation differences and alignment of topographic features combine with the effects of distance from continental and oceanic influences to produce a temperature-distribution pattern skewed to that of the southern half of the basin. Average temperatures for winter range from values of 22 to $24^{\circ} \mathrm{F}$ in the northern sector to over $36^{\circ} \mathrm{F}$ in the southern portions of the basin.

Because of the steep hemispheric temperature gradient that develops during winter, slight shifts in the midlatitude circulation features from one year to the next may result in significant departures from expected temperature values for midlatitude locations. Thus, the time series graphs (fig. 36) for winter temperatures in the Delaware River basin indicate considerable year-toyear variability. A slight decrease in average winter temperature is evident at all four transect stations during the 1950's and 1960's. The winters of 1971-72 through 1975-76 were relatively warm. The cold temperature conditions of the following three winters (1976-77 through 1978-79) are reflected in the graphs.
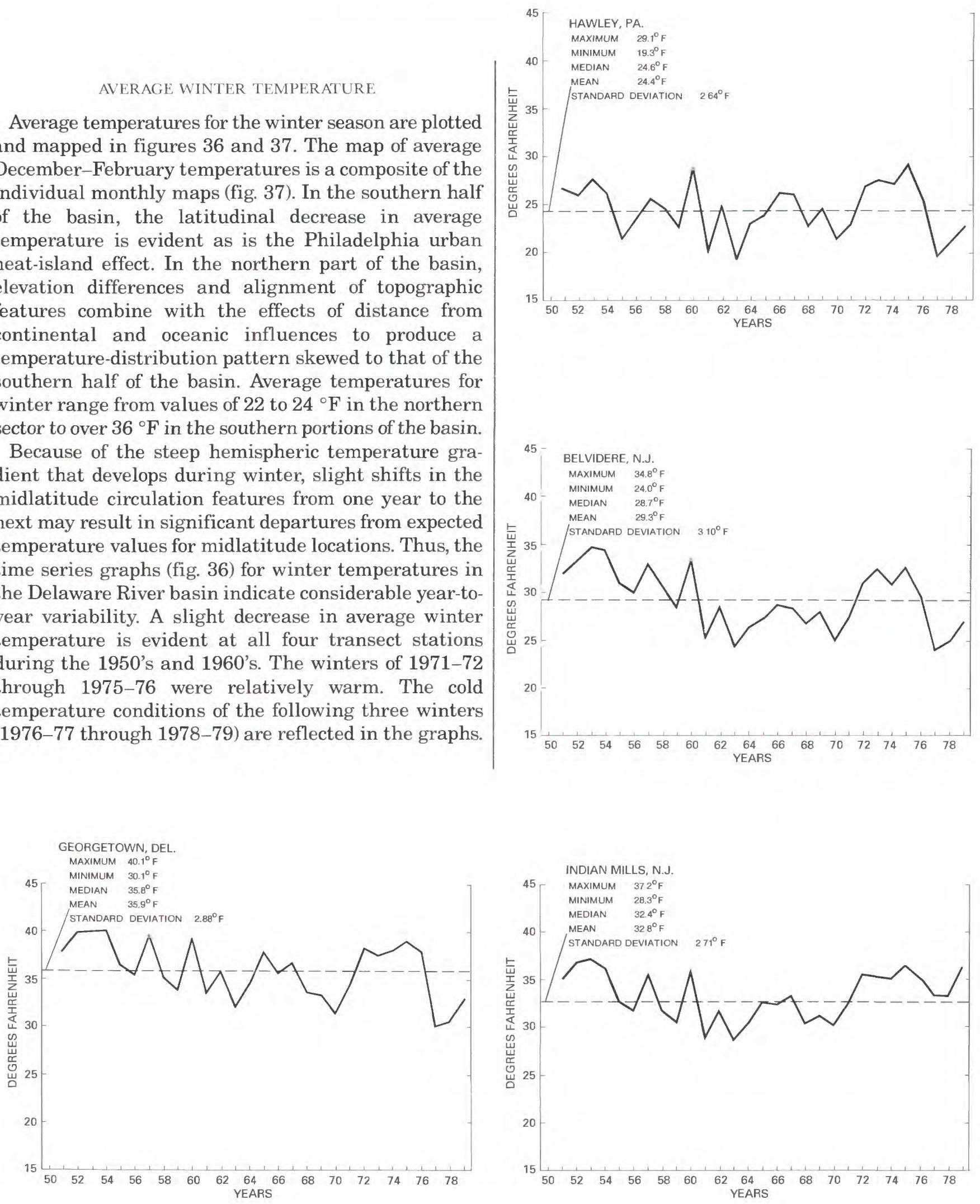

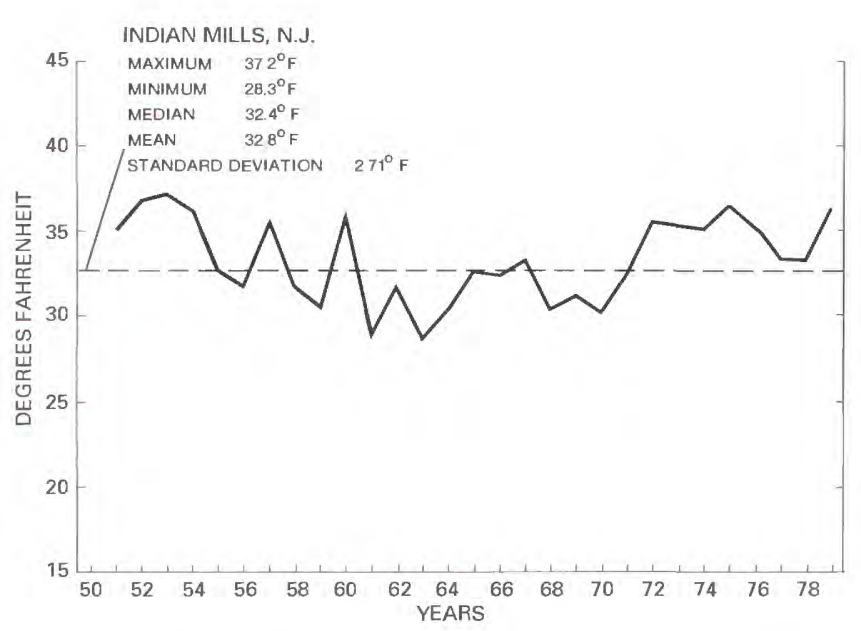

FigtiRe 36.-Average winter (December-February) temperatures at four stations in the Delaware River basin, $1950-79$. 


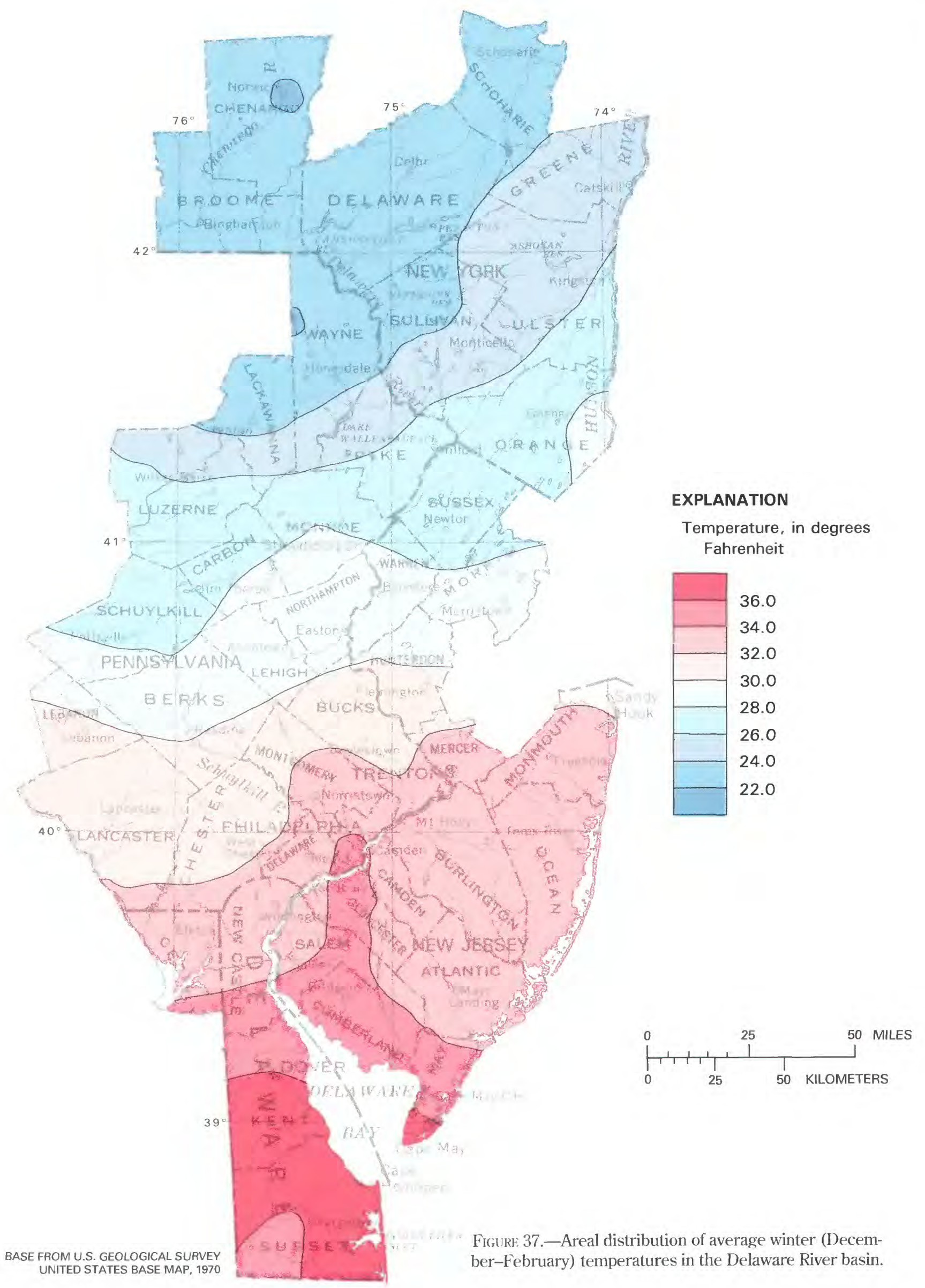




\section{AVERAGE SPRING TEMPERATURE}

Average spring (March-May) temperatures range from over $54{ }^{\circ} \mathrm{F}$ to less than $42^{\circ} \mathrm{F}$ (figs. 38 and 39 ). The Philadelphia area exhibits average temperatures of up to $2{ }^{\circ} \mathrm{F}$ warmer than outlying areas at the same latitude.

Less year-to-year variability exists in average spring temperature than in average temperature for the winter months. No year or period of years stands out as an extreme case.

The spring of 1977 was significantly warmer than the 30 -year average. This was a result of a weakening of the normally occurring East-Coast trough. A ridge existed over the East Coast and brought in warm air from the south (Taubensee, 1977). The trough was present along the coast during the following April but was weak in the latitude of the Delaware River basin (Wagner, 1977b).

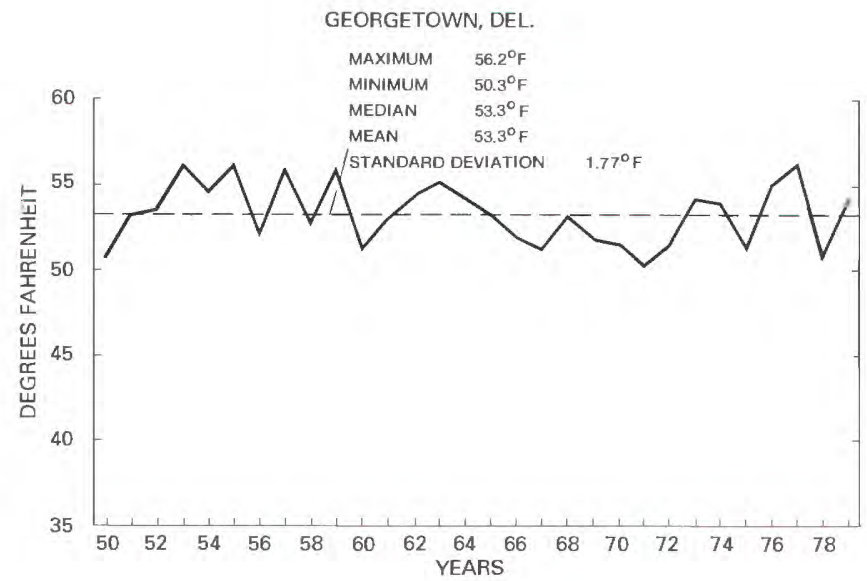

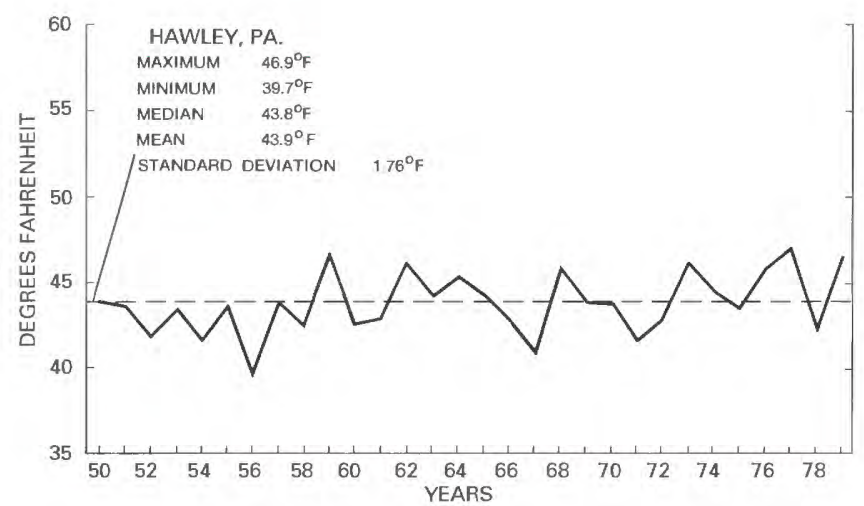
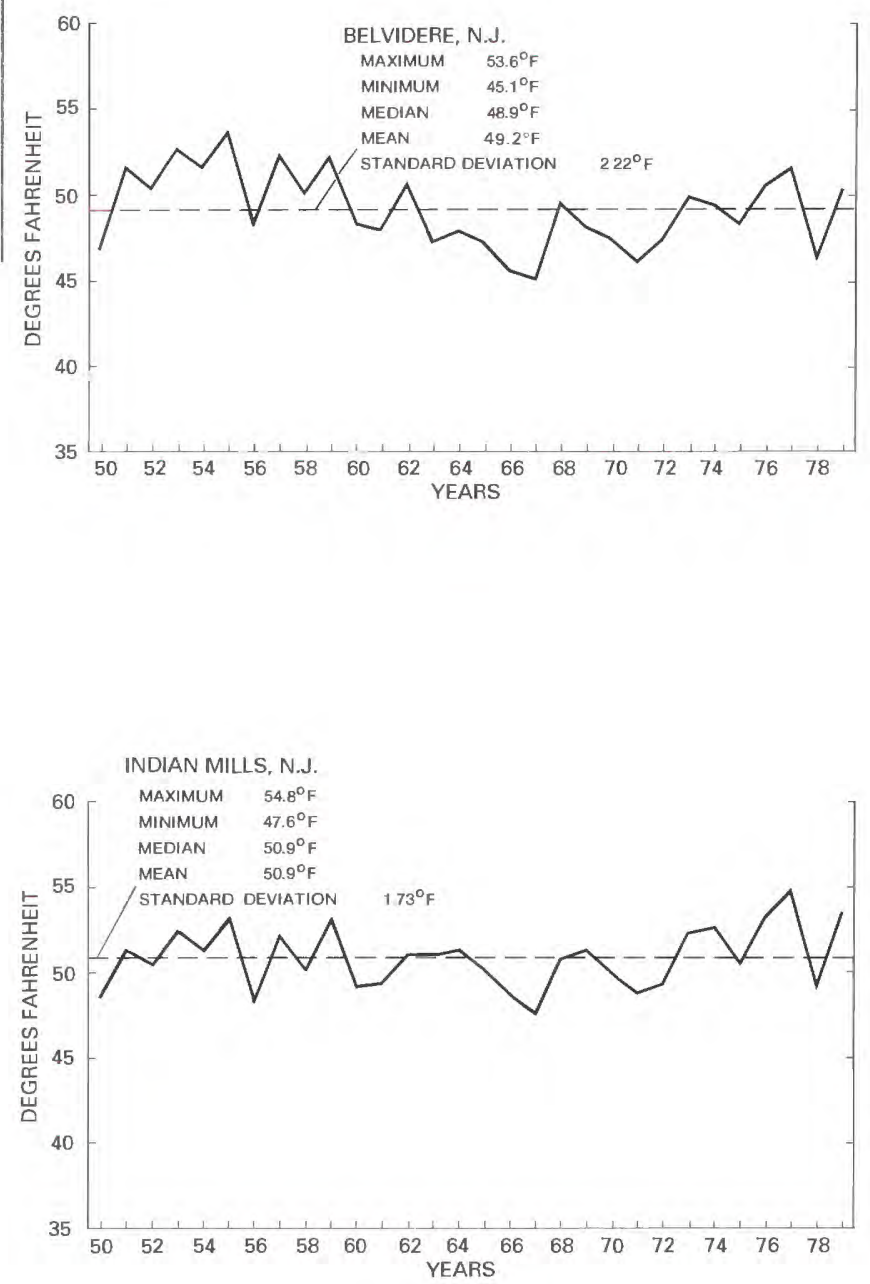

FIGURE 38.-Average spring (March-May) temperatures at four stations in the Delaware River basin, 1950-79. 


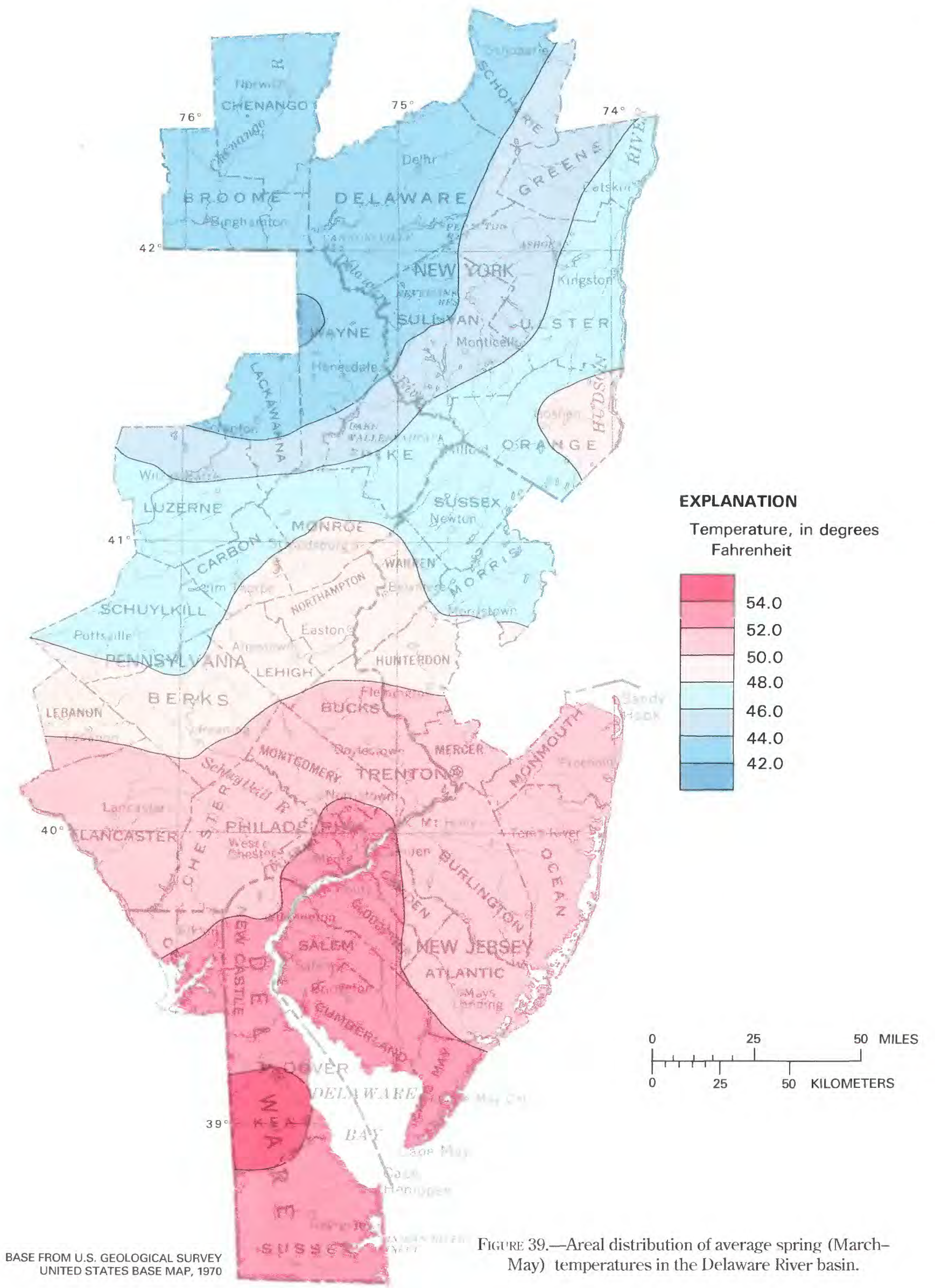


AVERAGE SLMMER TEMPERATLRE

Average summer (June-August) temperatures range from less than $64^{\circ} \mathrm{F}$ in the northern part of the basin to over $74^{\circ} \mathrm{F}$ in central and southern Delaware and in the Philadelphia area (figs. 40 and 41).

Summer is the season of minimal contrasts in temperature between high and low latitudes; therefore, little chance exists for extremes of temperature to occur during a particular year.
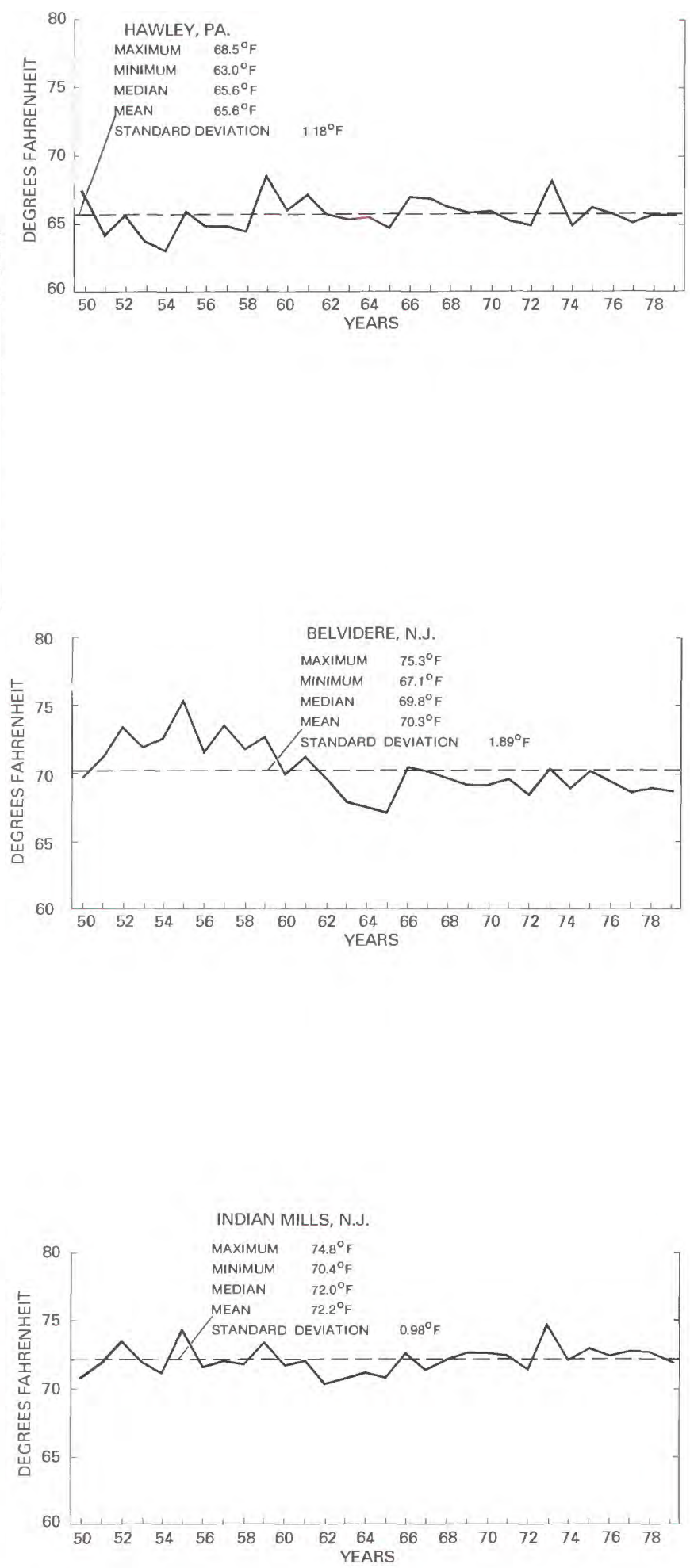

FigitiRe 40.-Average summer (June-August) temperatures at four stations in the Delaware River basin, 1950-79. 


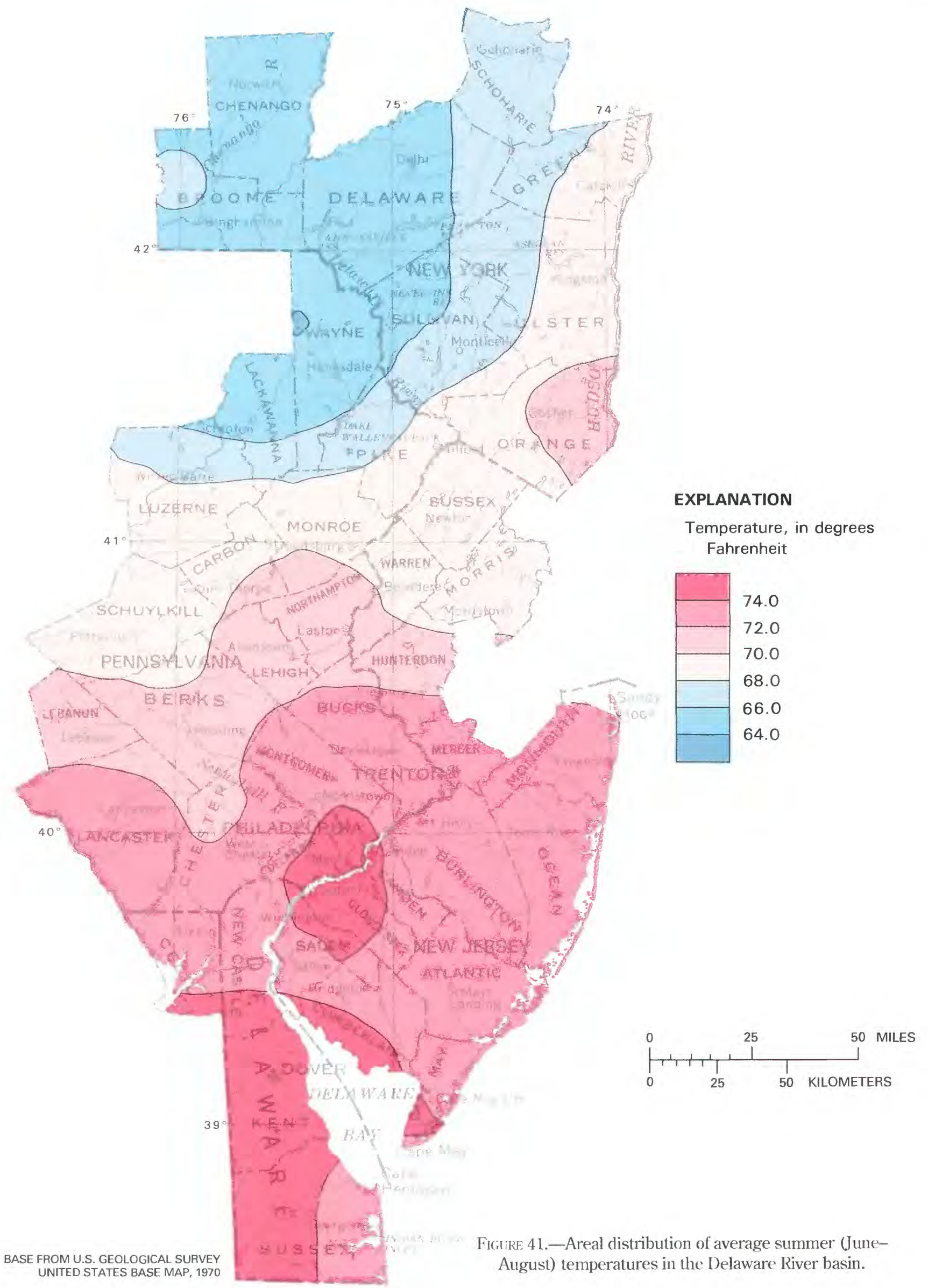


AVERAGE FALL. TEMPERATURE

Fall (September-November) average temperatures range from less than $48^{\circ} \mathrm{F}$ in the north to over $58{ }^{\circ} \mathrm{F}$ in Delaware (figs. 42 and 43). The Philadelphia area stands out as being relatively warm for the latitude.
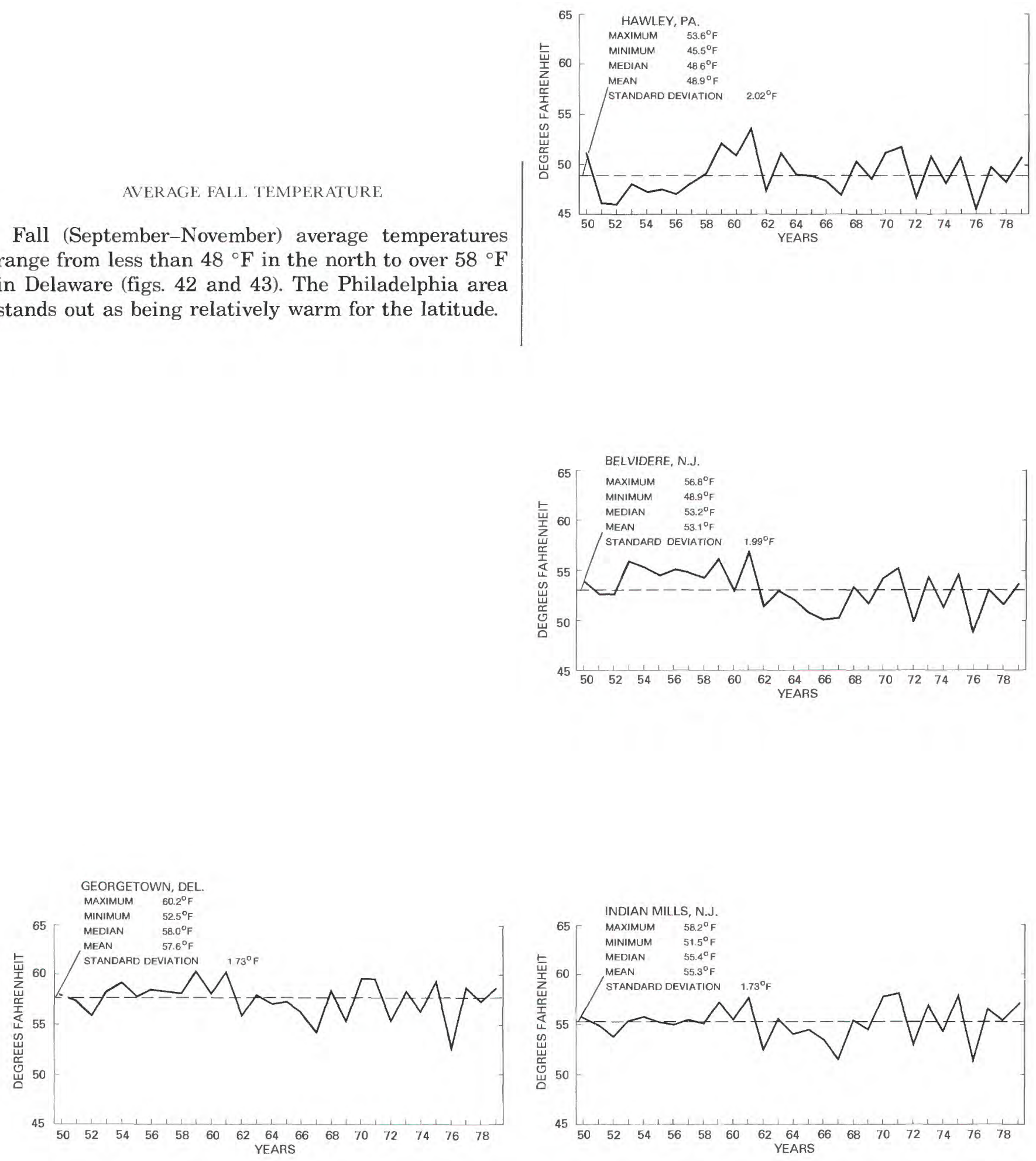

FIGLRE 42.-Average fall (September-November) temperatures at four stations in the Delaware River basin, 1950-79. 


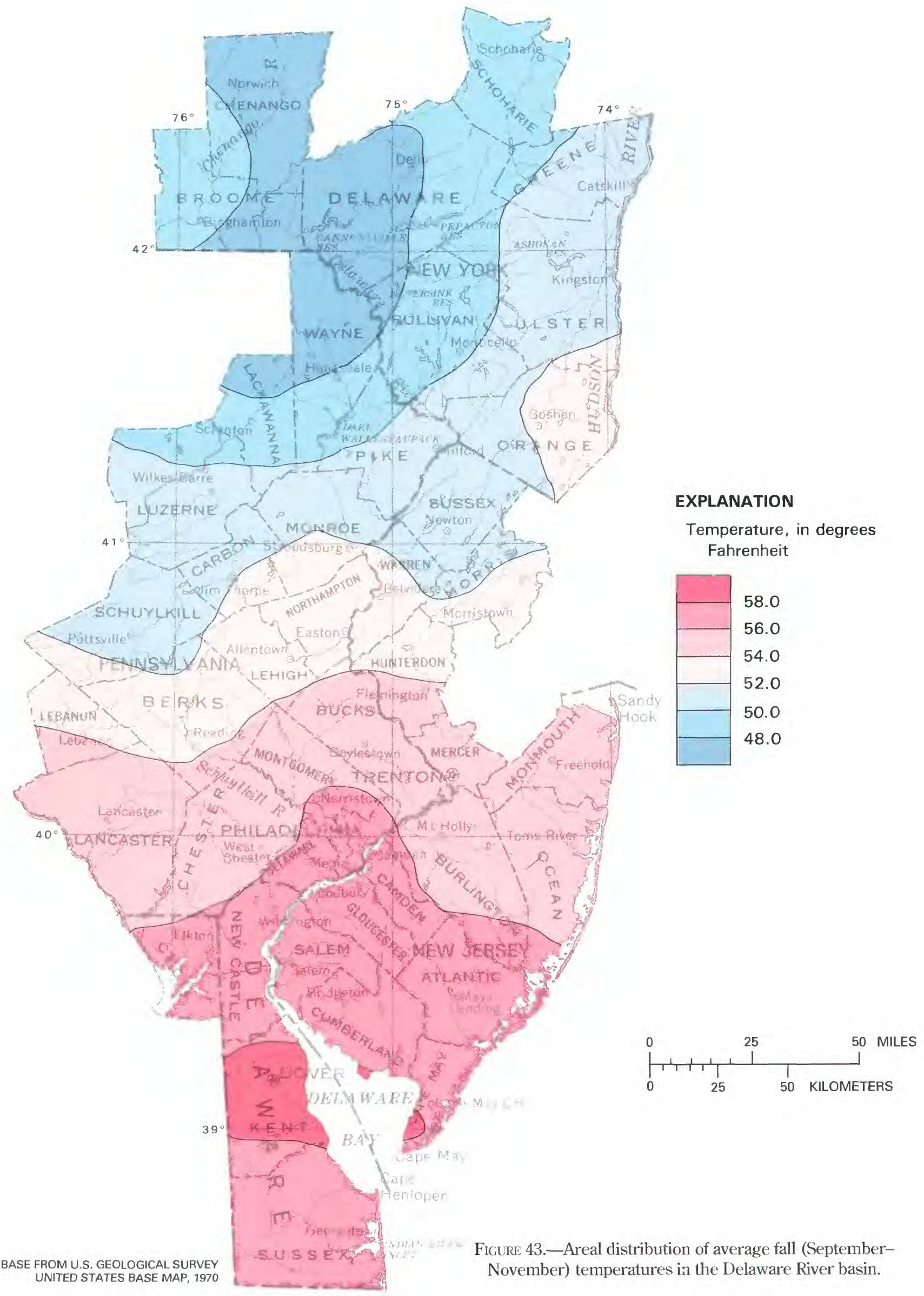




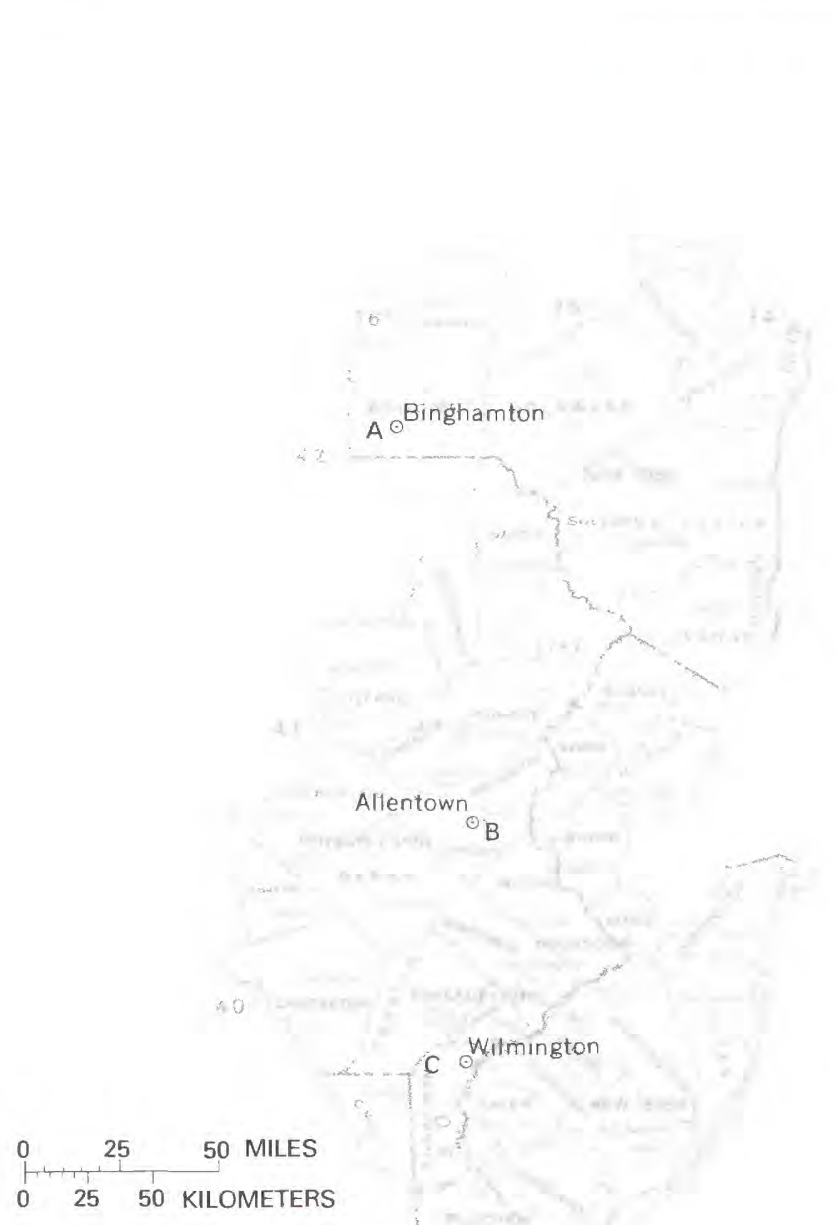

TEMPERATURE EXTREMES

Knowledge of typical diurnal variation in temperature for a month is sometimes more useful than a single monthly average temperature. Graphs of monthly averaged daily maximum and minimum temperature for three first-order stations are shown in figure 44. Average diurnal temperature range at all stations is slightly greater during the summer months than during the winter months, a result of greater average cloudiness in winter.

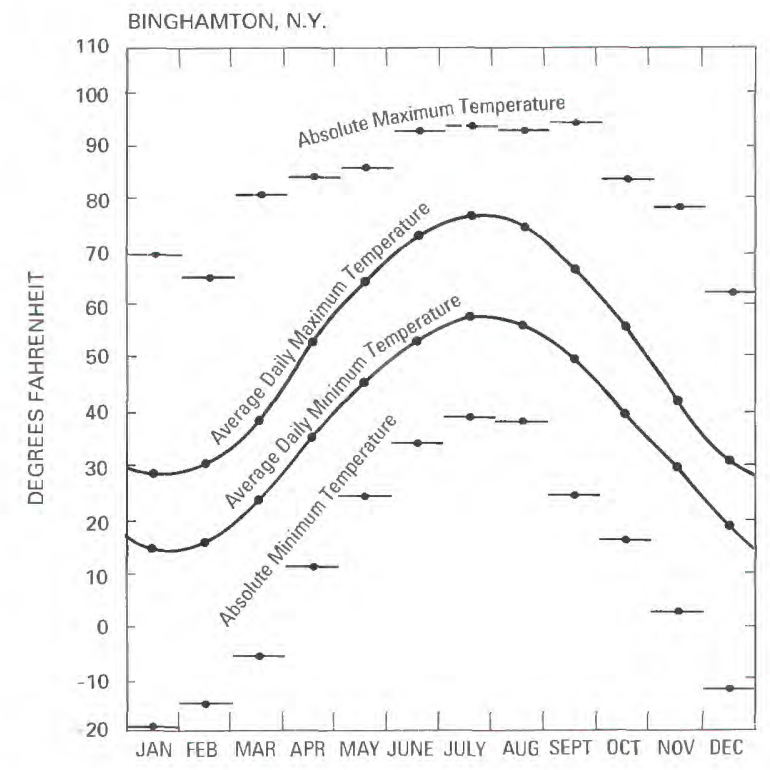

BASE FROM U.S. GEOLOGICAL SURVEY UNITED STATES BASE MAP, 1970
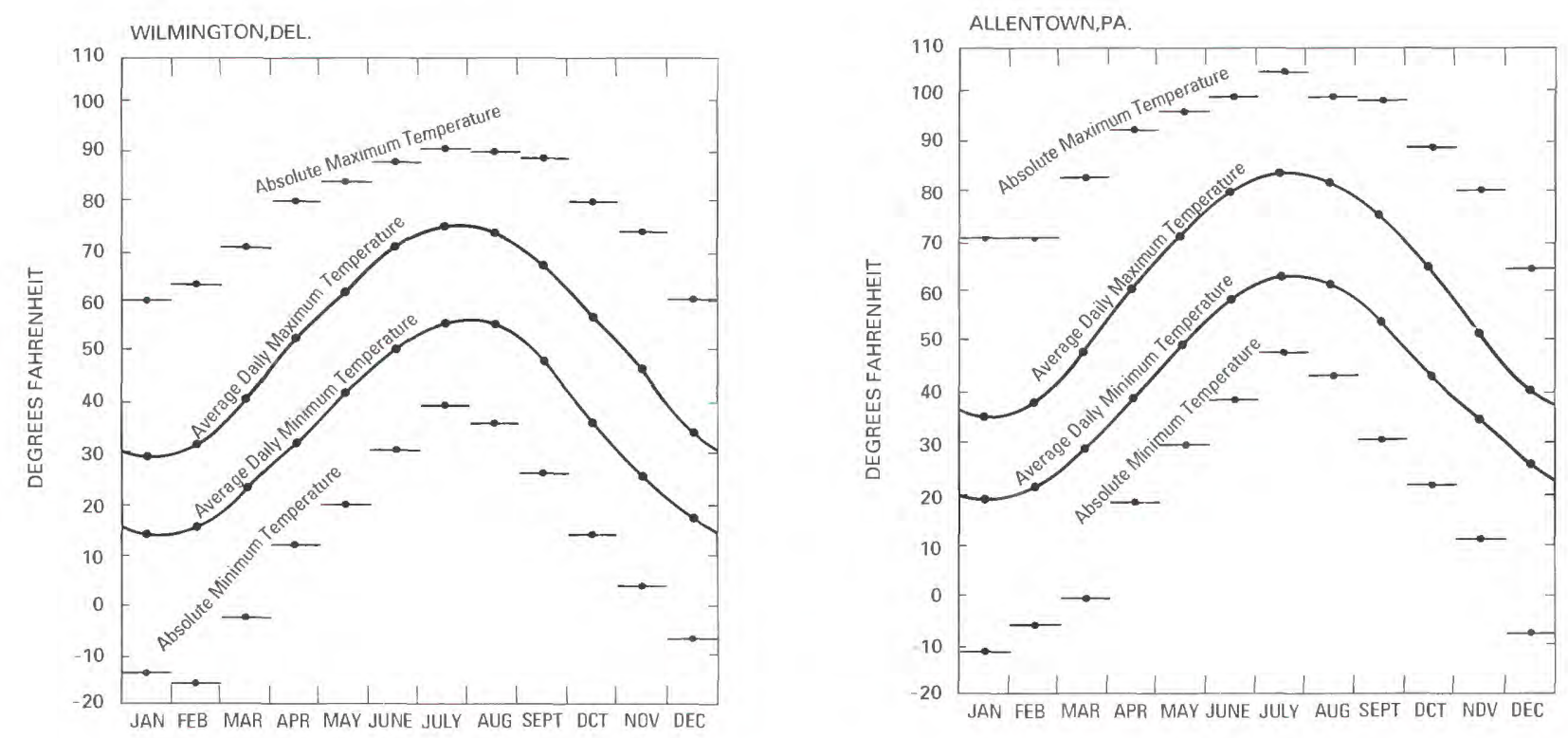

FigurE: 44.-Monthly averaged daily minimum and maximum temperatures at three stations in the Delaware River basin, 1950-79. 
Daytime cloud cover diminishes incoming radiational energy; the result is a lower daily maximum temperature than under clear sky conditions. A cloud cover very effectively absorbs and reradiates terrestrial radiation and thereby "traps" energy in the lower atmosphere (fig. 45). Daily minimum temperatures therefore tend to be higher under cloud cover than under clear sky conditions.

Figure 44 also shows the absolute extreme daily maximum and minimum temperatures, that is, the highest and lowest temperatures recorded during a given month for the 1950-79 period. The greatest range between maximum and minimum values is associated with the winter months. These extreme temperature measurements represent short term, rather than persistent, conditions. The winter months, with great contrasts in temperature north and south of the basin, are associated with a higher probability of extreme temperature occurrences in either direction.

The graphs in figure 46 show the yearly time series of average daily maximum and minimum temperatures for the months of January and July for the years 1950-79.
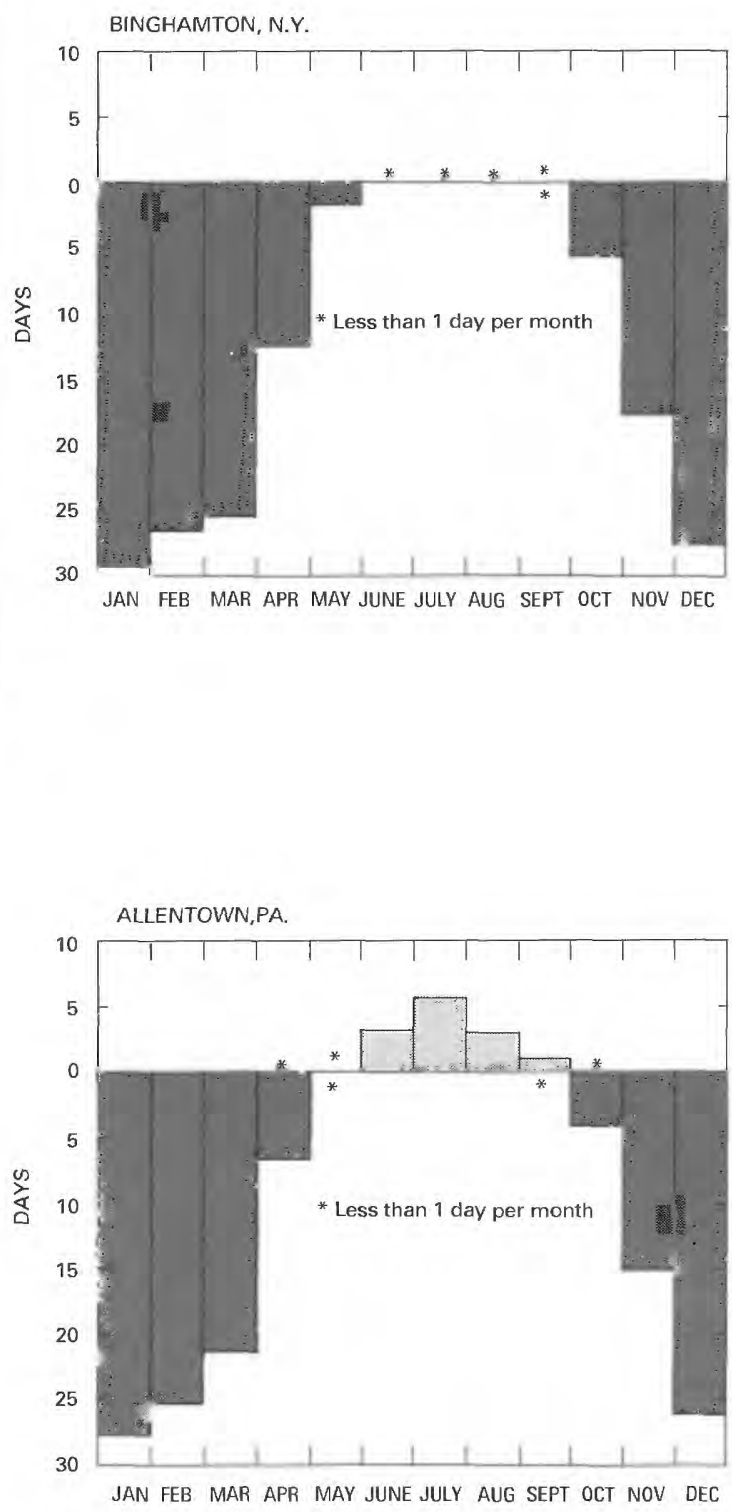

\section{EXPLANATION}

Average number of days per month with maximum temperature $90{ }^{\circ} \mathrm{F}$ or above

Average number of days per month with minimum temperature $32{ }^{\circ} \mathrm{F}$ or below

FIGURE 45.-Average frequency of days per month of temperatures equal to or above $90^{\circ} \mathrm{F}$ and equal to or below $32^{\circ} \mathrm{F}$ at three stations in the Delaware River basin. 
The frequency with which a particular threshold value of temperature is exceeded is important for many climatic applications. The critical threshold may be related to the planning of outdoor work such as construction, to the design of a building heating or cooling system, or to the scheduling of agricultural activities. Because each application is associated with a different set of critical temperatures, it is not practical to include all possibilities here.

Graphs indicating the average frequency of days per year with temperature equal to or exceeding $90^{\circ} \mathrm{F}$ and

Average Daily Maximum and Minimum Temperature -January
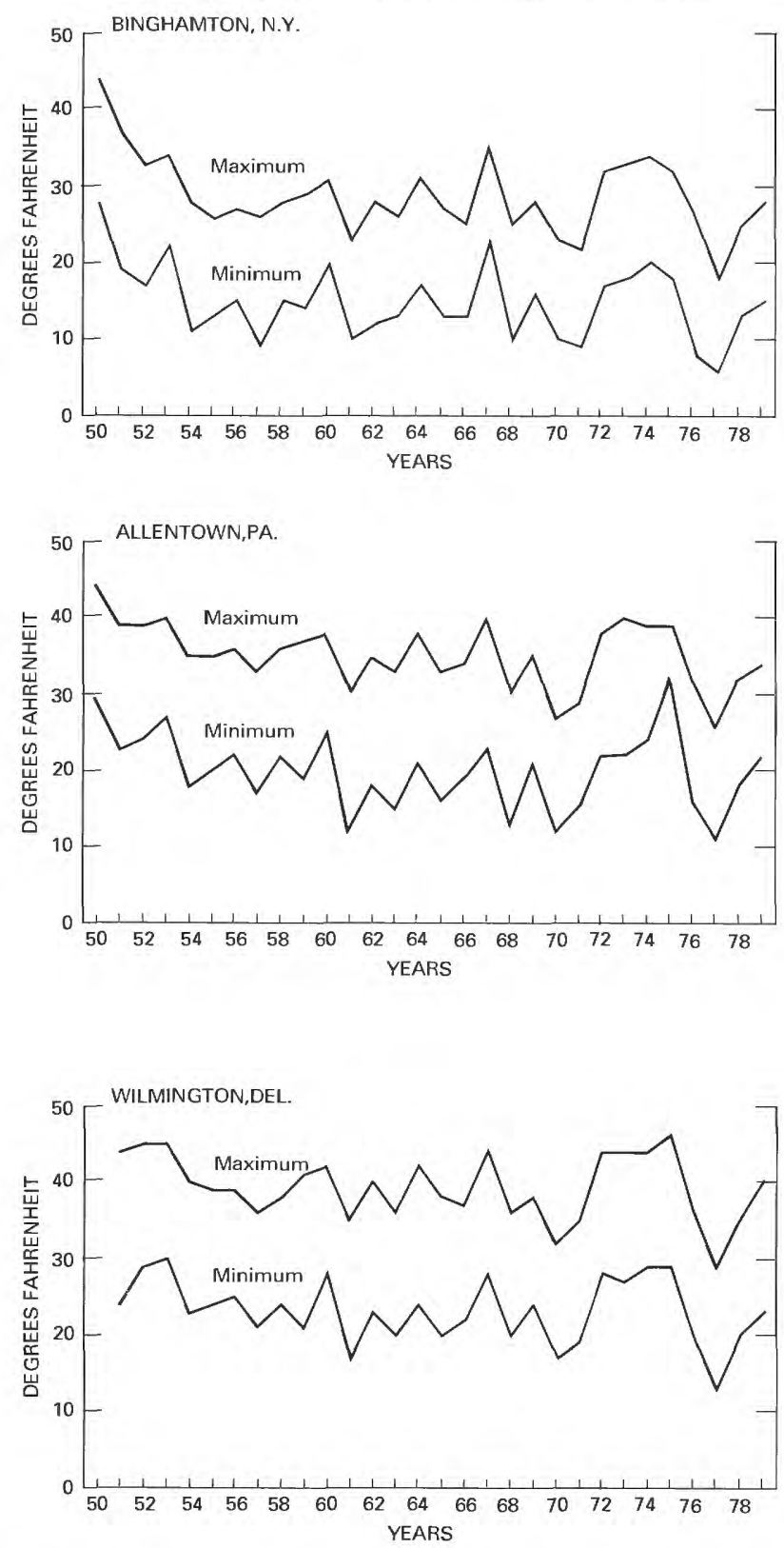

the frequency of days with minimum temperatures of 32 ${ }^{\circ} \mathrm{F}$ or below are shown in figure 47 . The latitudinal trend is obvious. Wilmington, Del., averages 18 days of temperatures $90^{\circ} \mathrm{F}$ or above per year; Allentown, Pa., averages 14 days; and Binghamton, N.Y., averages 2 days. A systematic trend also appears in the frequency of days with subfreezing temperature. For example, the average number of days with minimum temperature of $32{ }^{\circ} \mathrm{F}$ or below is 102 for Wilmington, Del., 125 for Allentown, Pa., and 147 for Binghamton, N.Y. (fig 47).
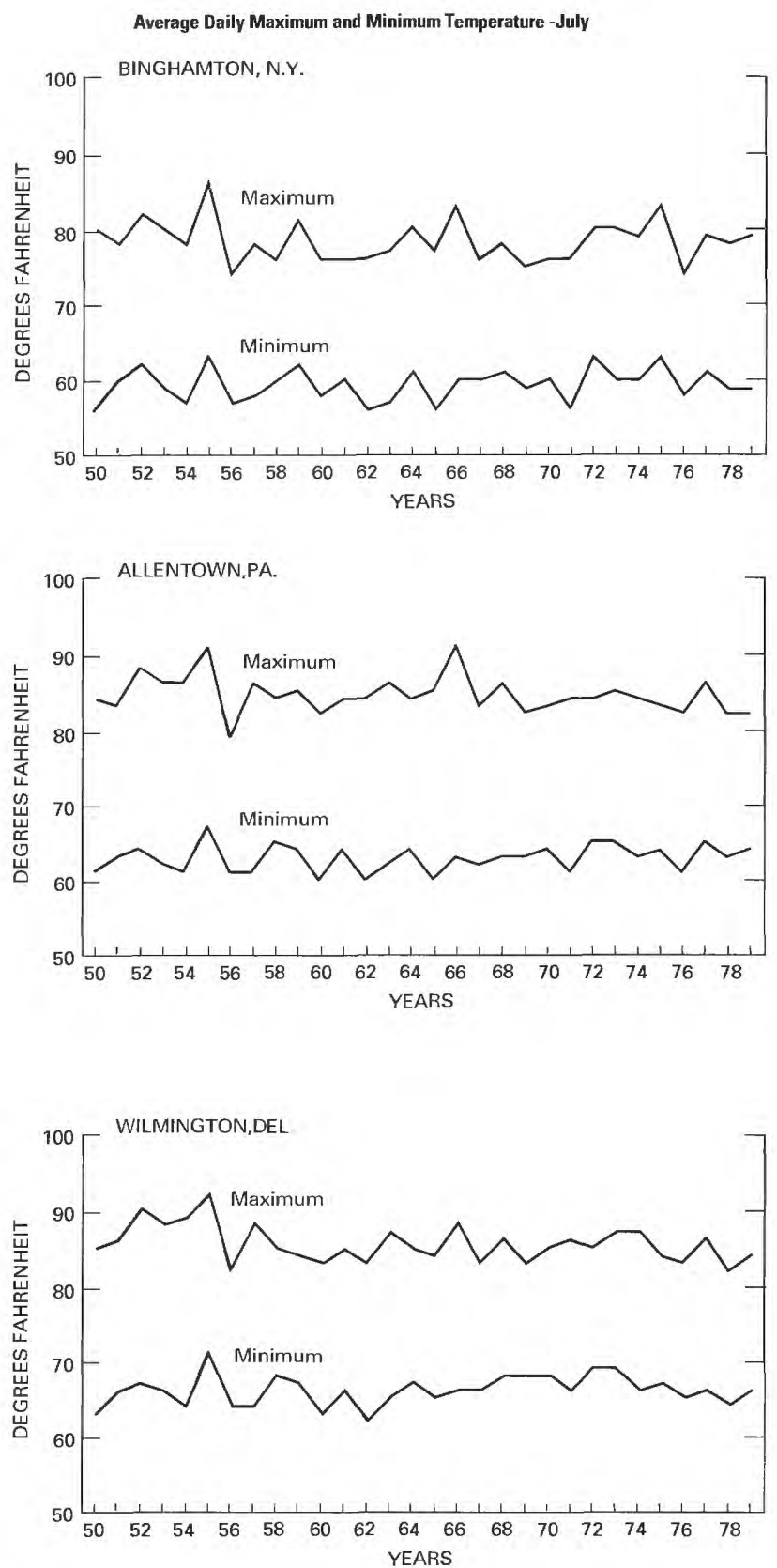

FiguRE 46.-Average daily maximum and minimum temperatures for January and July, 1950-79, at three stations in the Delaware River basin. 

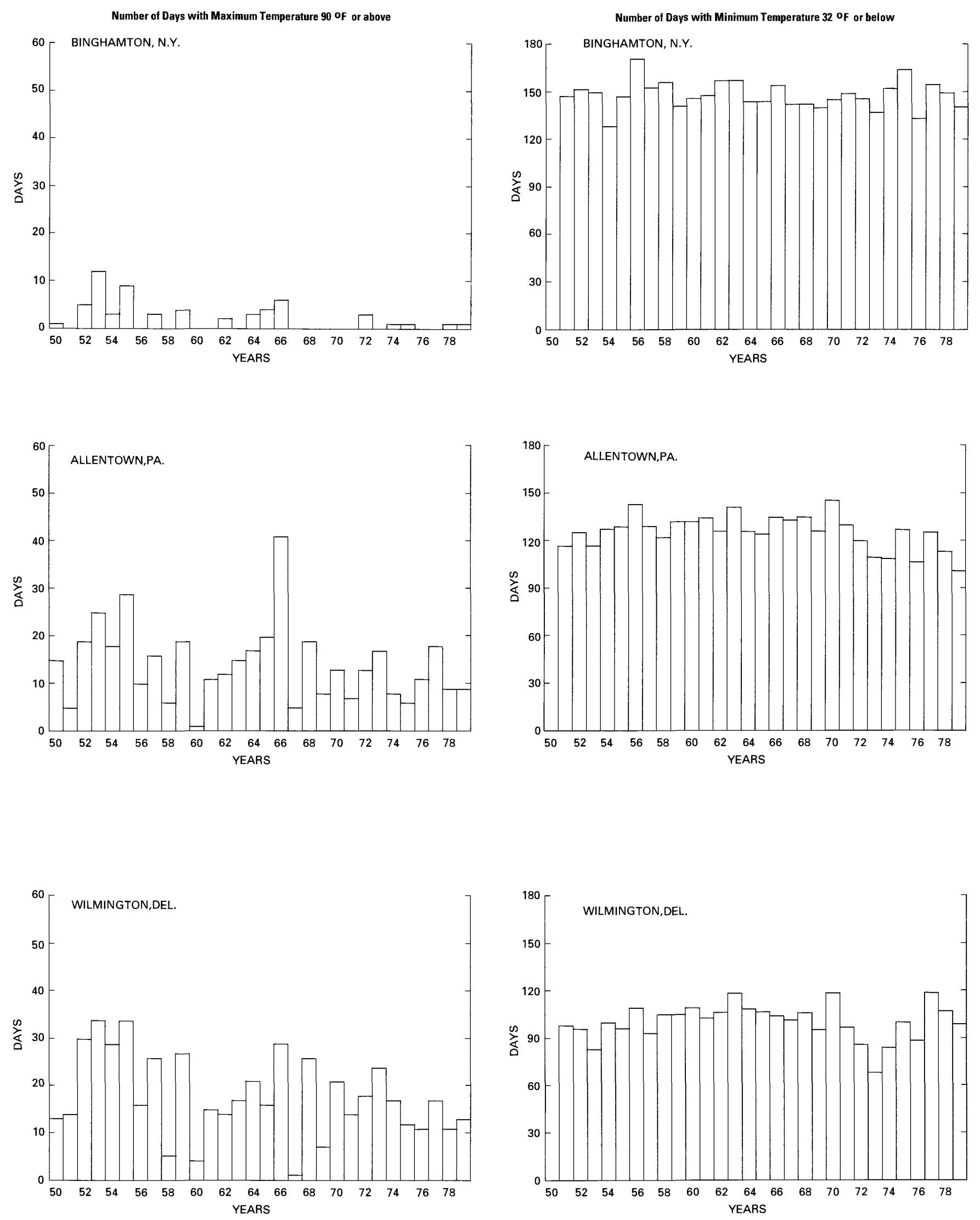

FiguRE 47.-Average frequency of days per year of temperatures equal to or above $90^{\circ} \mathrm{F}$ and equal to or below $32{ }^{\circ} \mathrm{F}$ at three stations in the Delaware River basin, 1950-79. 


\section{HEATING DEGREE DAYS}

The heating degree-day statistic was developed for use by the heating industry, and it relates outdoor air temperature to fuel consumption for heating purposes (figs. 48 and 49). A temperature of $65^{\circ} \mathrm{F}$ is commonly used as a base value. Presumably, no heating is necessary when the average daily temperature is greater than $65^{\circ} \mathrm{F}$. Heating degree days for a day during which the average temperature is less than $65^{\circ} \mathrm{F}$ are calculated by subtracting that average temperature from the base value. The heating degree-day total for the day with an average temperature of $45^{\circ} \mathrm{F}$ would be 20 .

The graphs on figure 49 show the average monthly distributions of heating degree days for the three firstorder transect stations. Annual average heating degreeday totals for the 1951-79 heating seasons are 4,991, 5,756, and 7,329 for Wilmington, Del., Allentown, Pa., and Binghamton, N.Y., respectively.

Time series plots of the annual total heating degree days for the same three stations are shown in figure 48 .
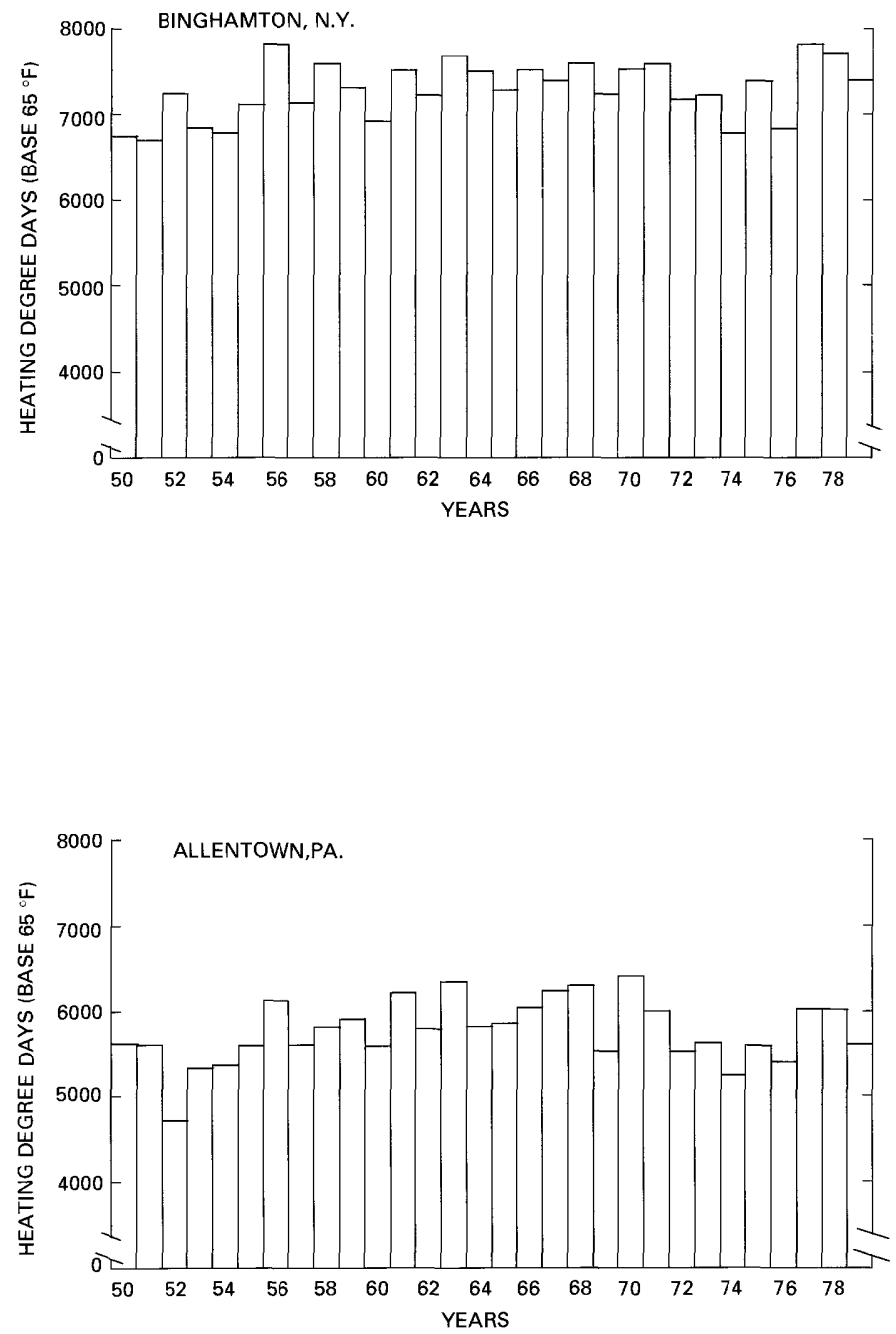

FIGURE 48.-Total annual heating degree days for three stations in the Delaware River basin. 

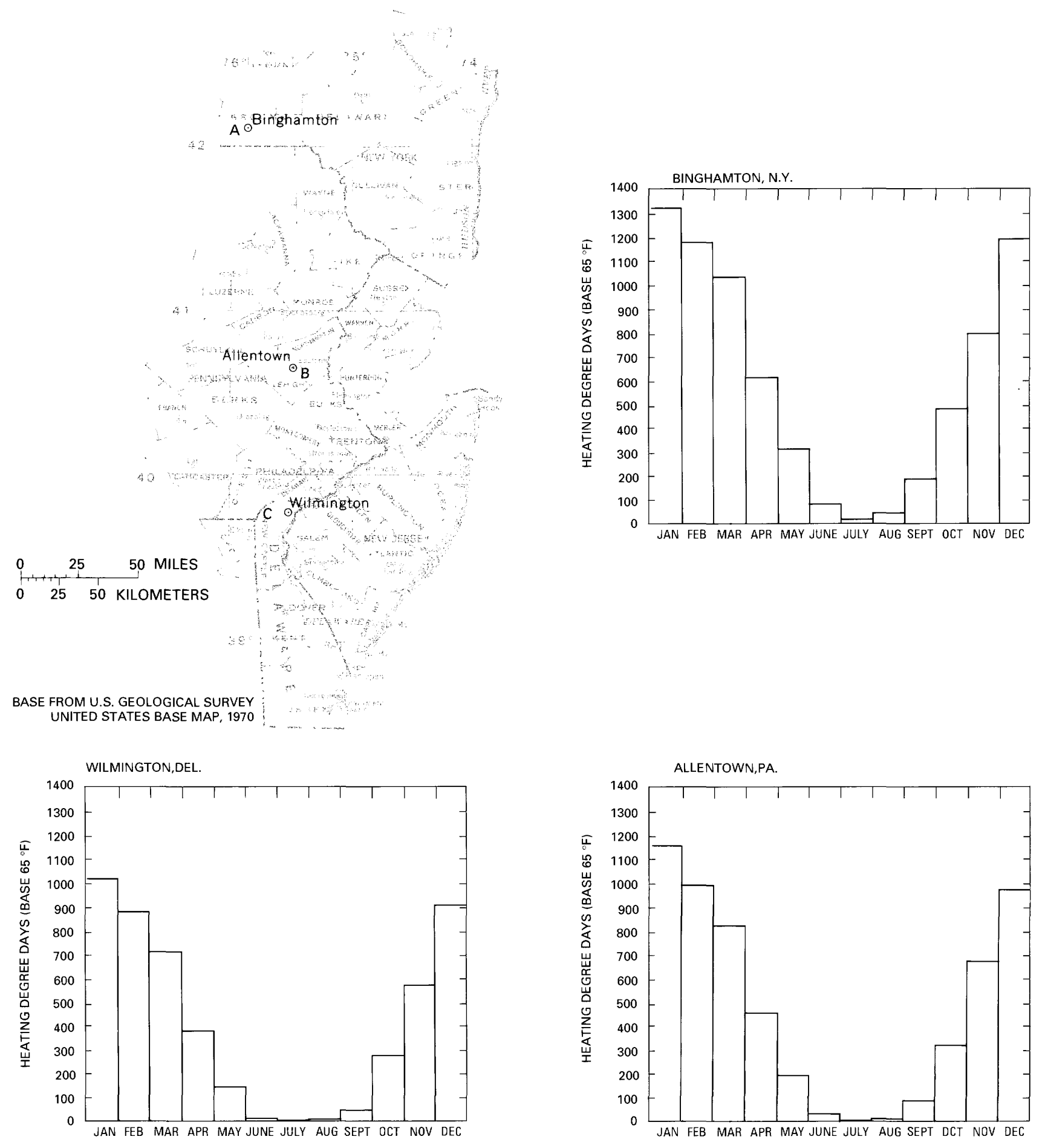

FIGURE 49.-Average monthly distribution of heating degree days for three stations in the Delaware River basin. 


\section{FREEZE-FREE SEASON}

Another temperature-related climatic parameter relates not to the frequency with which a particular threshold value is exceeded but instead to the period of the year during which air temperatures remain above $32{ }^{\circ} \mathrm{F}$. It is often incorrectly termed the "frost-free" season. This term is inaccurate because frost formation occurs when the surface temperature, not the air temperature, reaches a critically low level and when atmospheric humidity and turbulence conditions are favorable. Frost will not always form when air temperature is below the freezing level. The freeze-free season is often equated with the growing season. Again, surface conditions are more important in determining growing conditions than is air temperature measured at screen height. Also, conditions favorable to growth vary according to plant species, so there is really no single definable growing season.

Graphs depicting the average length of the freeze-free season (fig. 50) and the average date of the last $32^{\circ} \mathrm{F}$ temperature in spring, and first $32{ }^{\circ} \mathrm{F}$ temperature in fall (fig. 51) indicate substantial year-to-year variability.

Maps of these same three freeze-free season variables appear as figures 52-54.
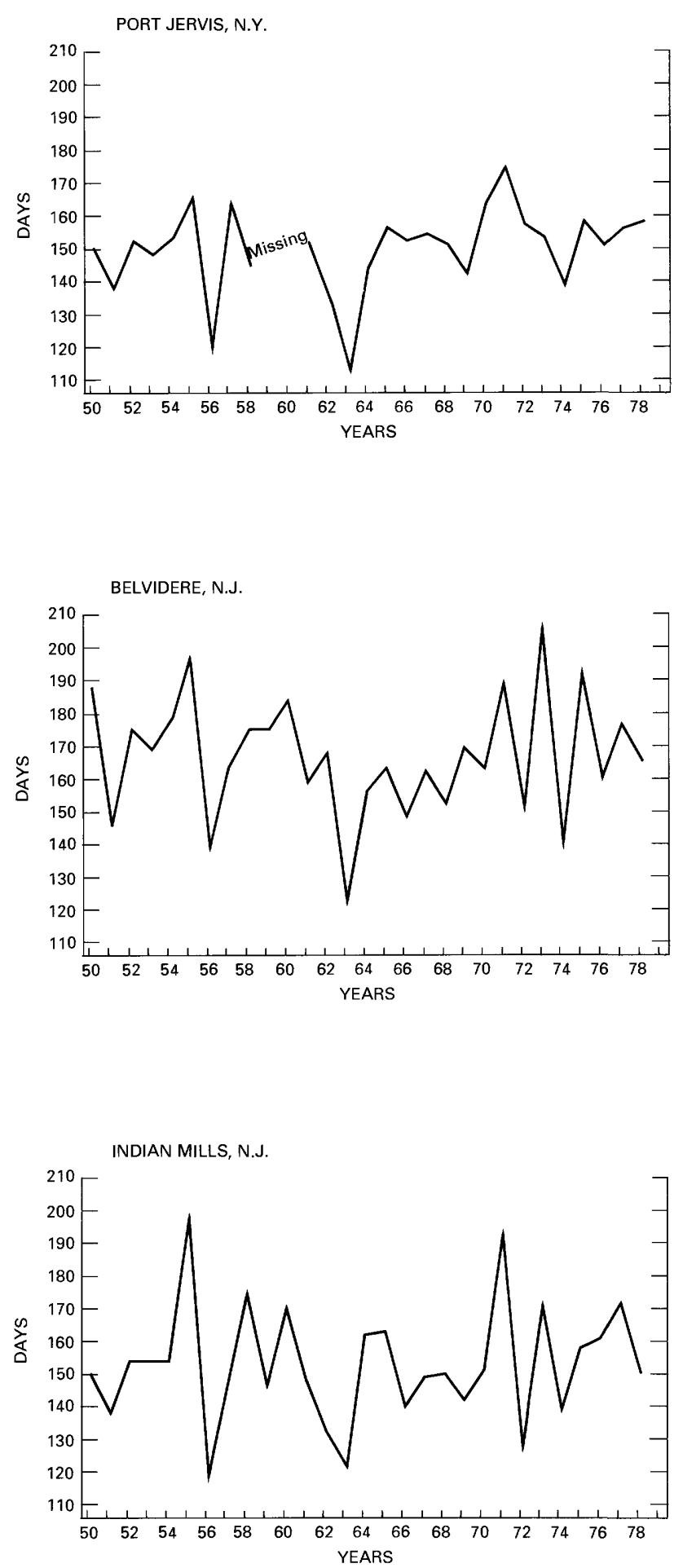

FiguRE 50.-Daily length of the freeze-free season at four stations in the Delaware River basin, 1950-79. 

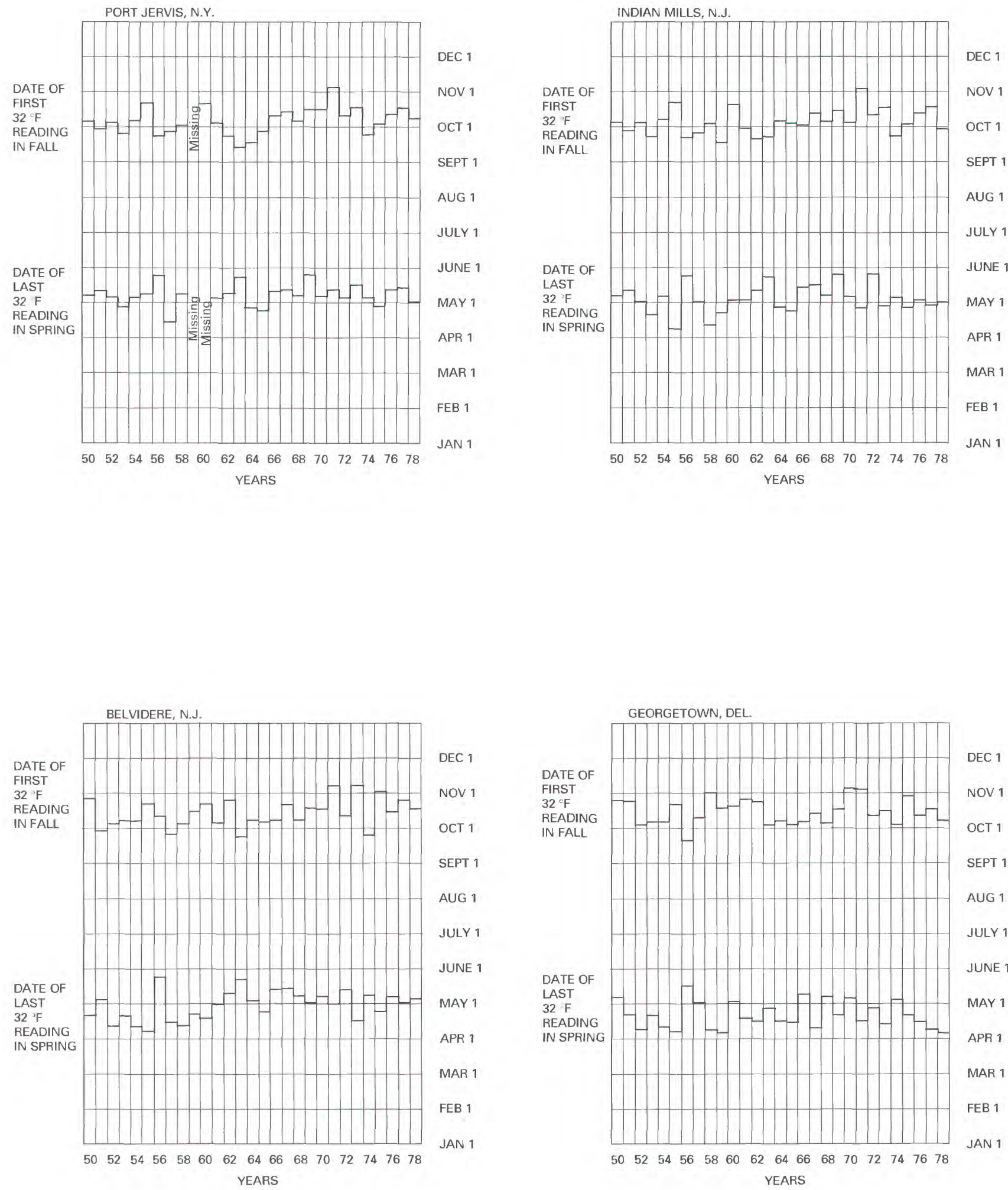

FigLRE 51.-Daily last minimum temperature in spring and first minimum temperature in fall at four stations in the Delaware River basin, 1950-79. 


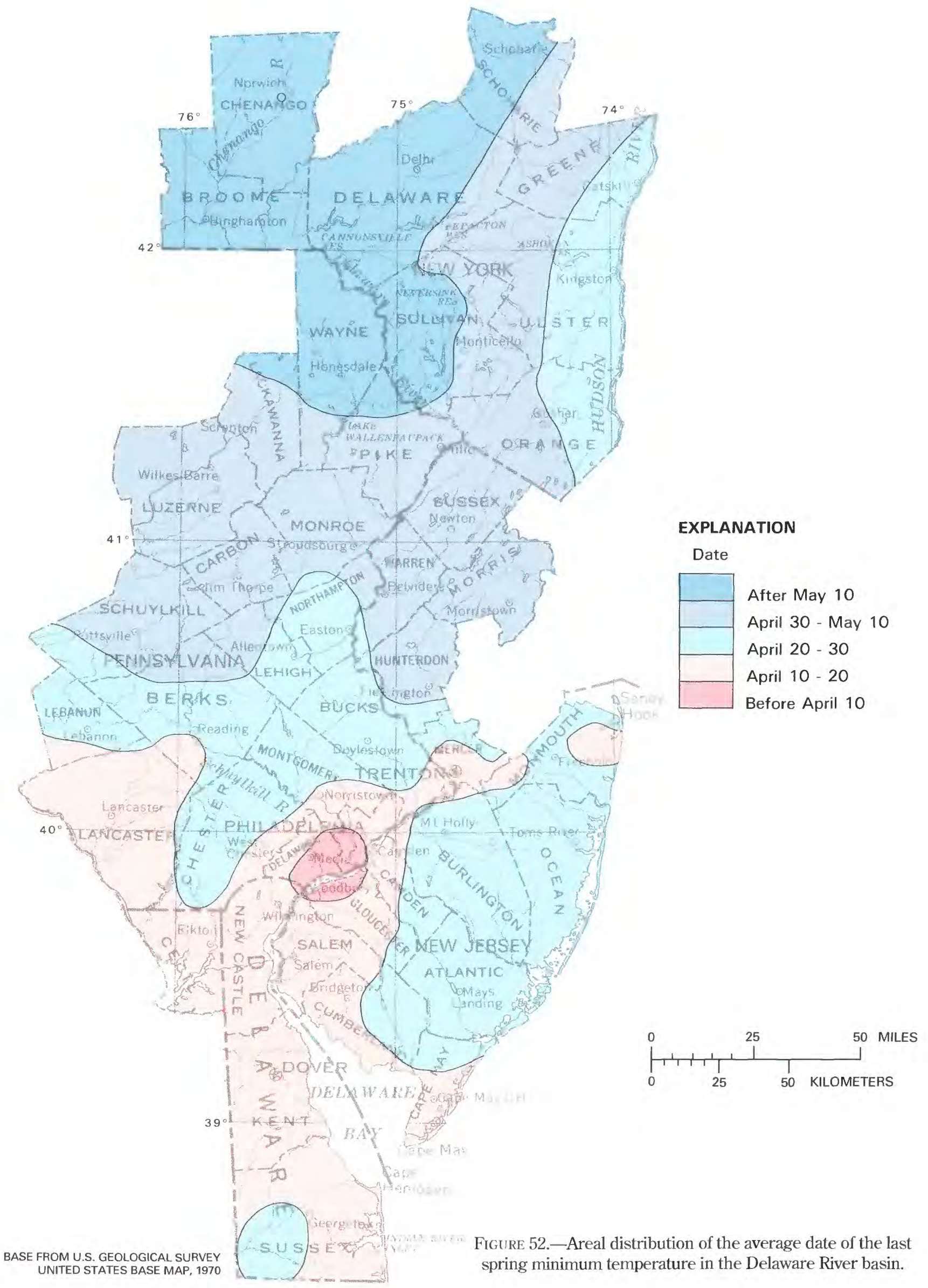




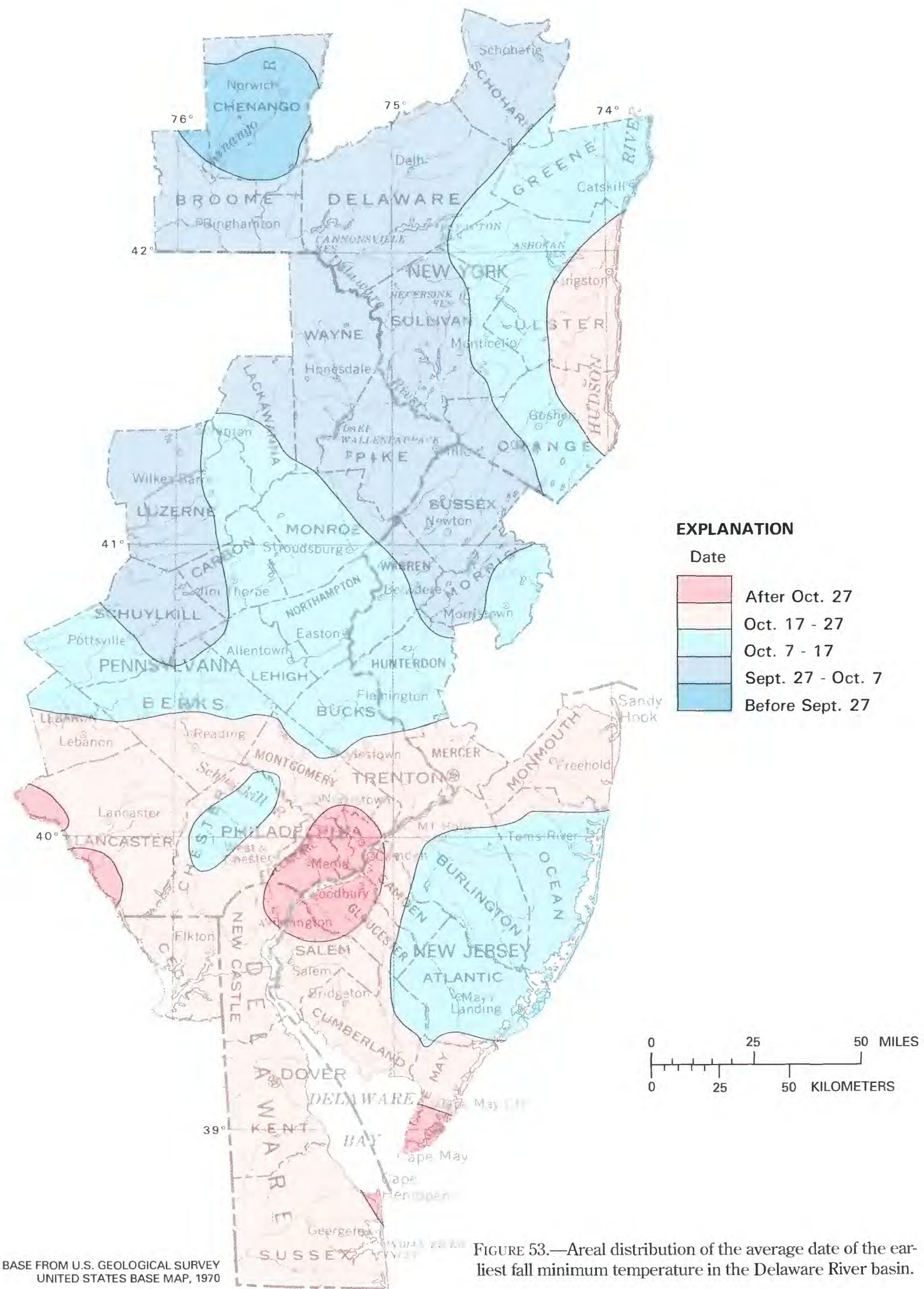




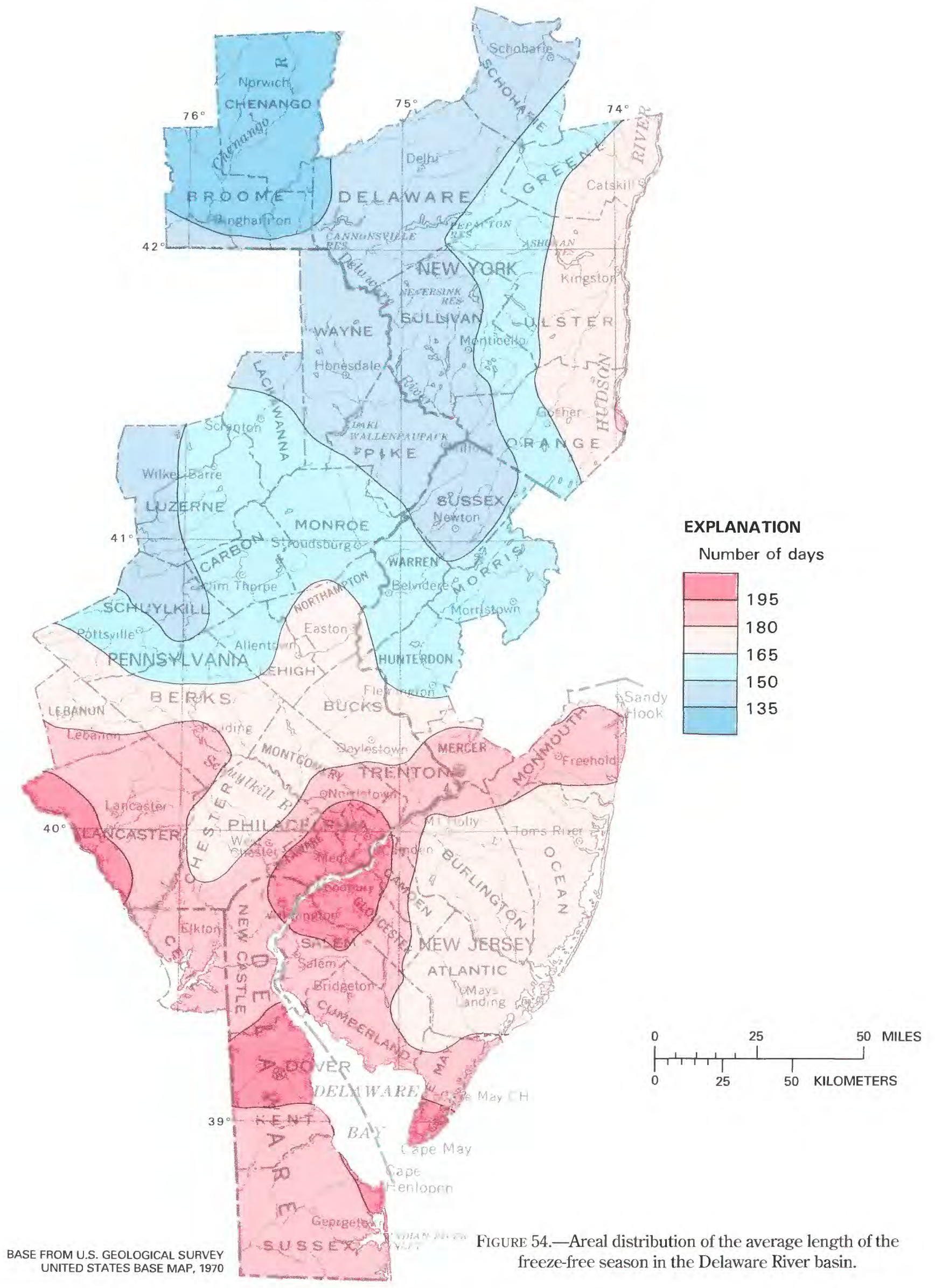




\section{PRECIPITATION}

Although average monthly precipitation values indicate little seasonality in amount, there is a distinct seasonality in precipitation-producing mechanisms affecting the Delaware River basin. Migrating cyclonic systems are of greatest importance during the winter months. As the polar front shifts northward, during the warm season, moist Atlantic or gulf air is circulated into the region by the subtropical high pressure systems. Because of the convective nature of the resulting precipitation, summer rainfall patterns are less continuous than those of winter. Contributions by hurricanes and other systems of tropical origin are also included in warm season precipitation, in some years.

The most important local influence on precipitation receipt is terrain. Forced lifting of a moist air mass often leads to precipitation on one side of a ridge and a precipitation "shadow" effect on the other. Within the Delaware River basin, the rugged Catskills have a 3,500-foot elevation range and are associated with complex precipitation patterns. Terrain effects are also important in the other upland areas of the basin (fig. 55). Maps and time series plots are provided for monthly and seasonal precipitation values. In each case considerable year-to-year variability is evident. The mean and median values of the time series are presented with each graph. Often a marked difference exists between the two values because the distribution of precipitation values for a station is bounded by zero and tends to be positively skewed. The median precipitation value for many applications would be more representative of average precipitation conditions than would the calculated mean.

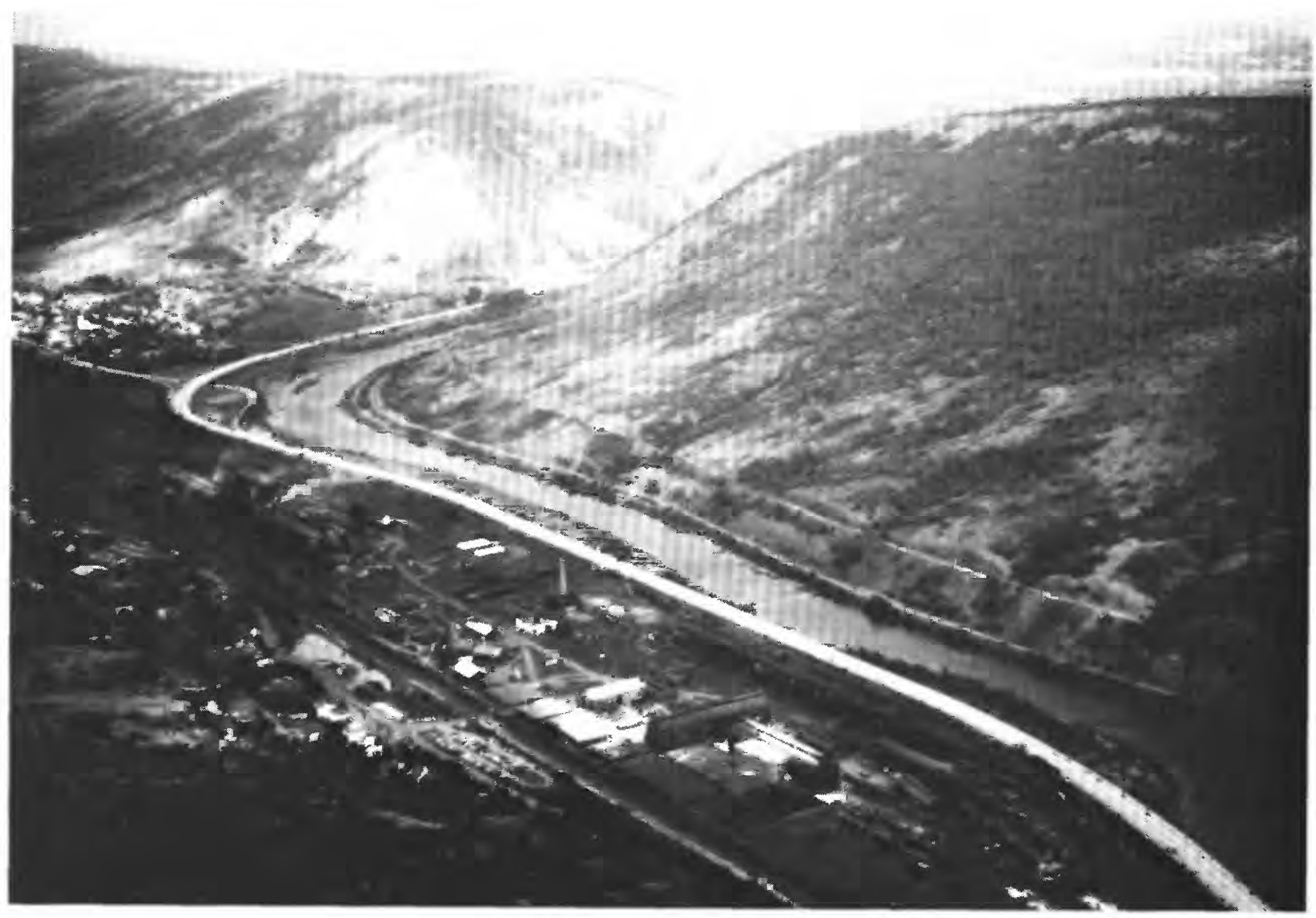

FIGURE 55.-Northeast-trending ridges at Palmerton, Pa., which are the significant landforms of the ridge-and-valley area of the Delaware River basin. 

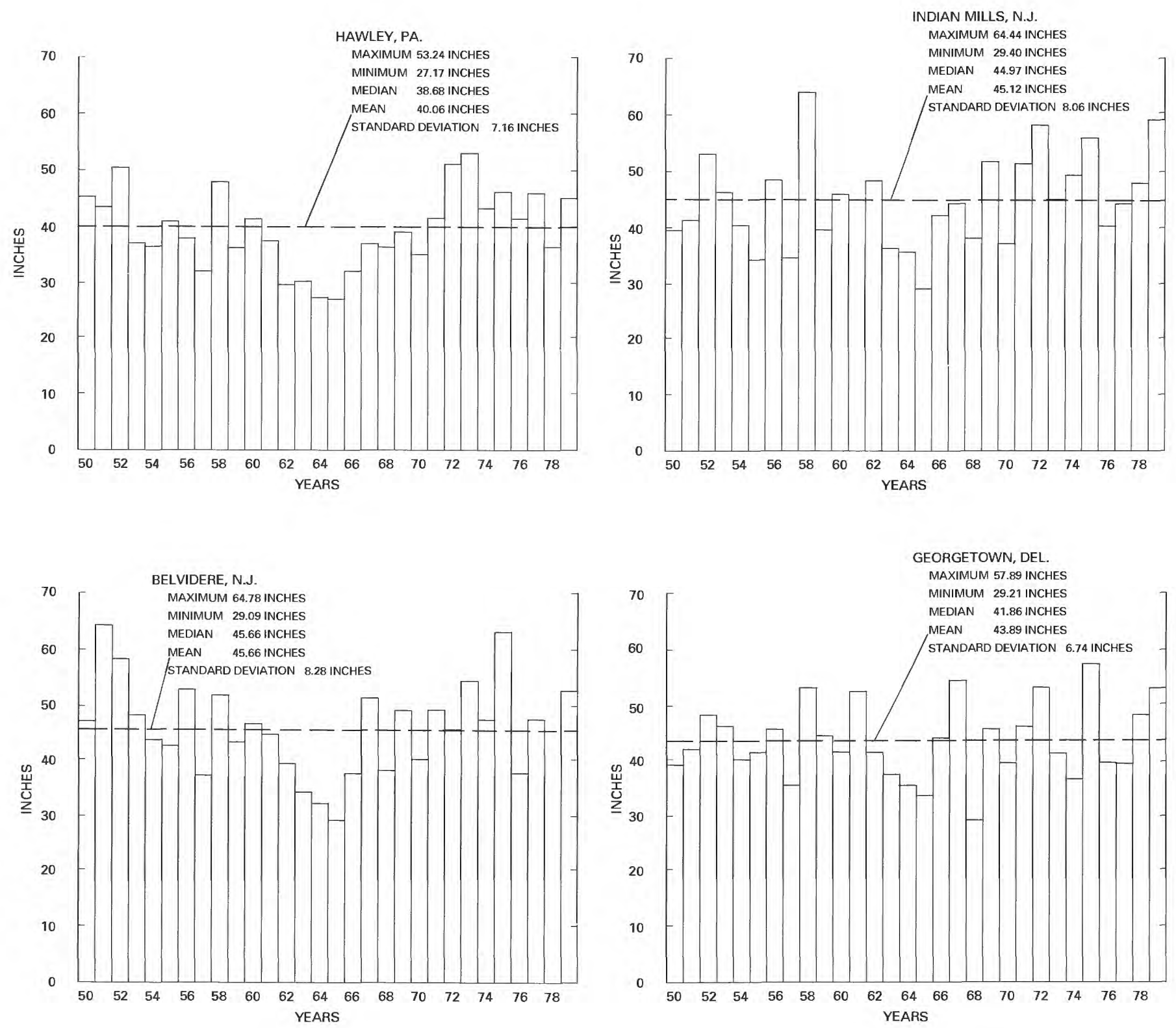

FIGURE 56.-Average annual precipitation at four stations in the Delaware River basin, 1950-79. 


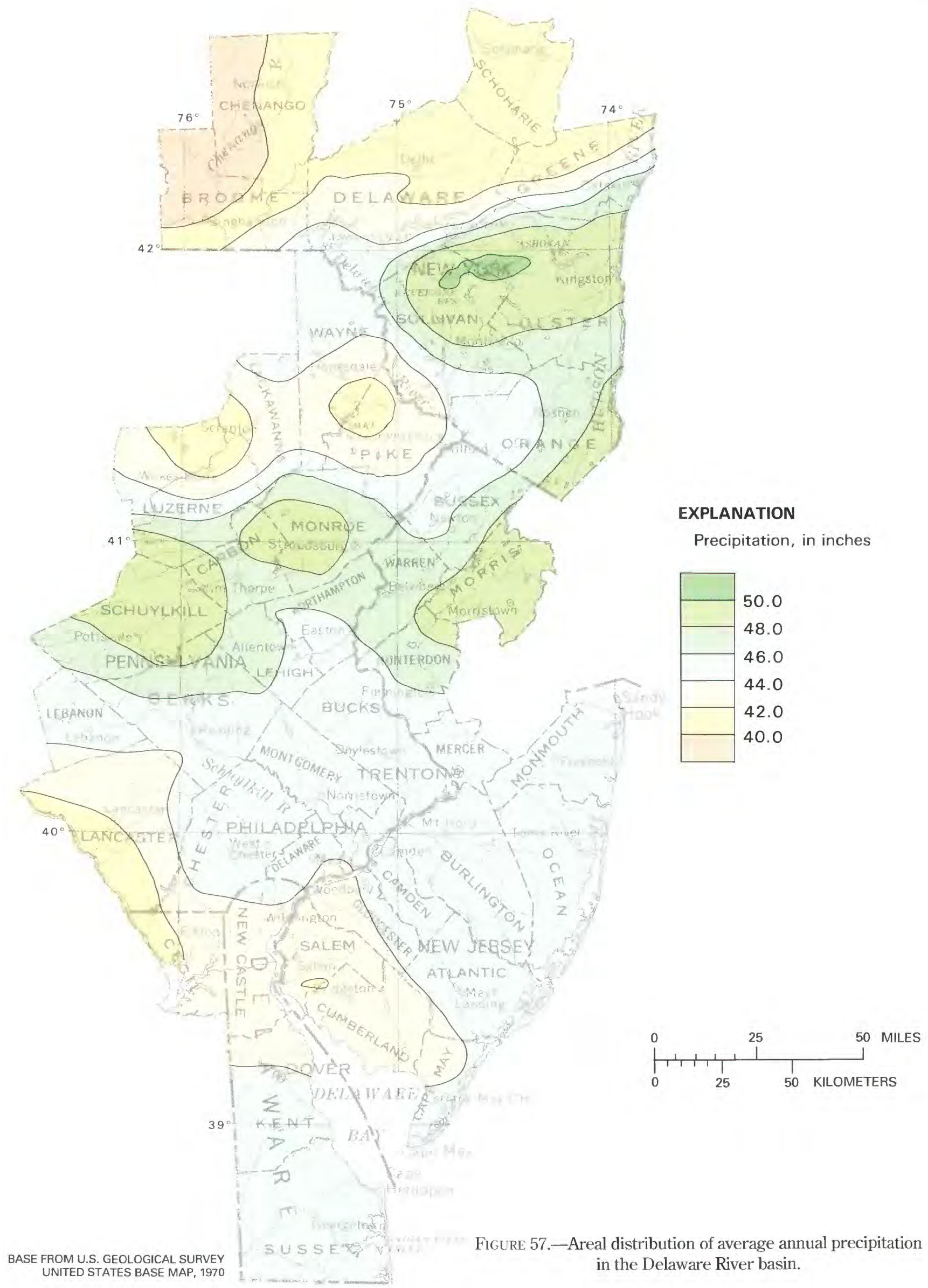



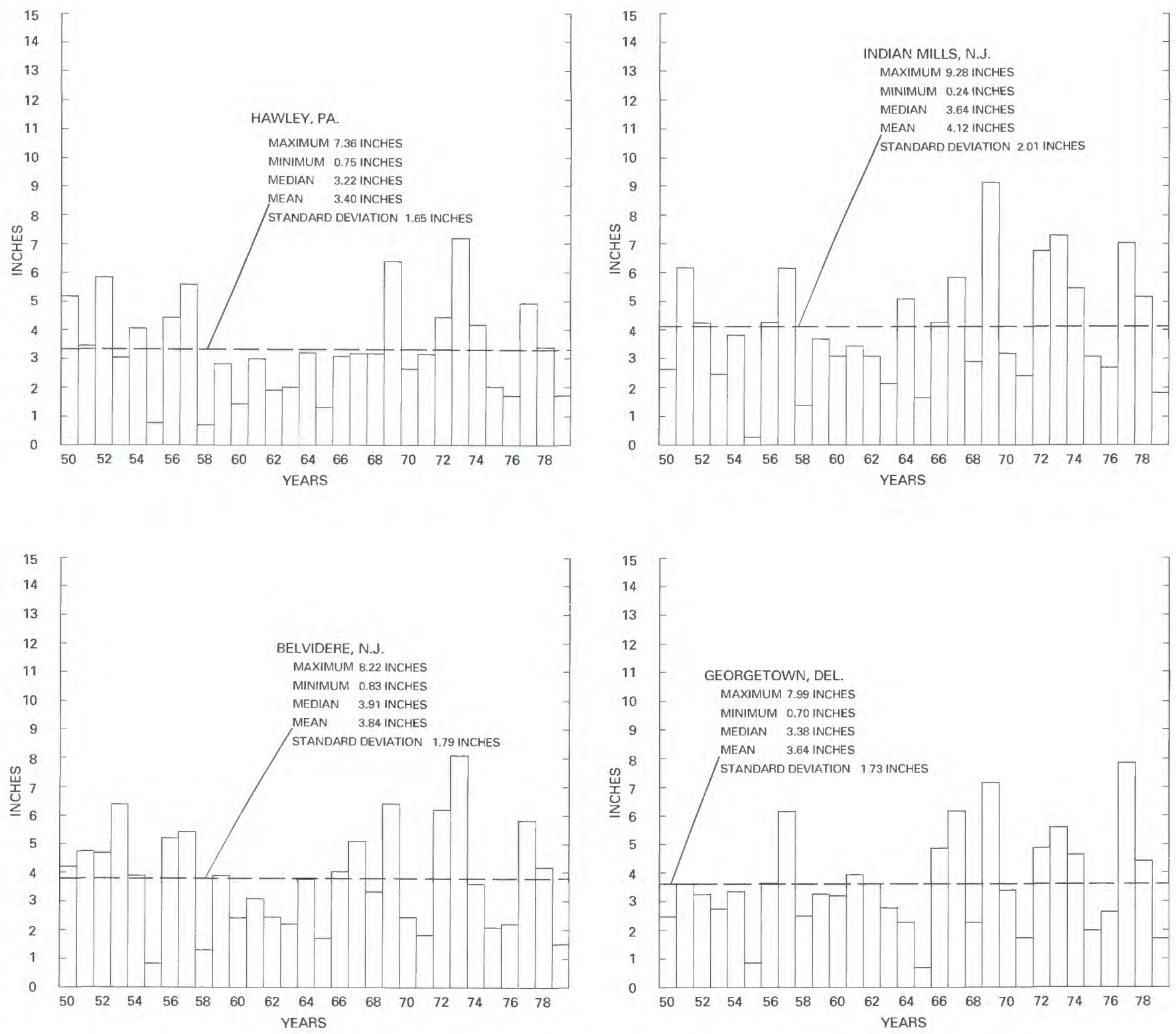

FIGURE 58.-Average December precipitation at four stations in the Delaware River basin, 1950-79. 


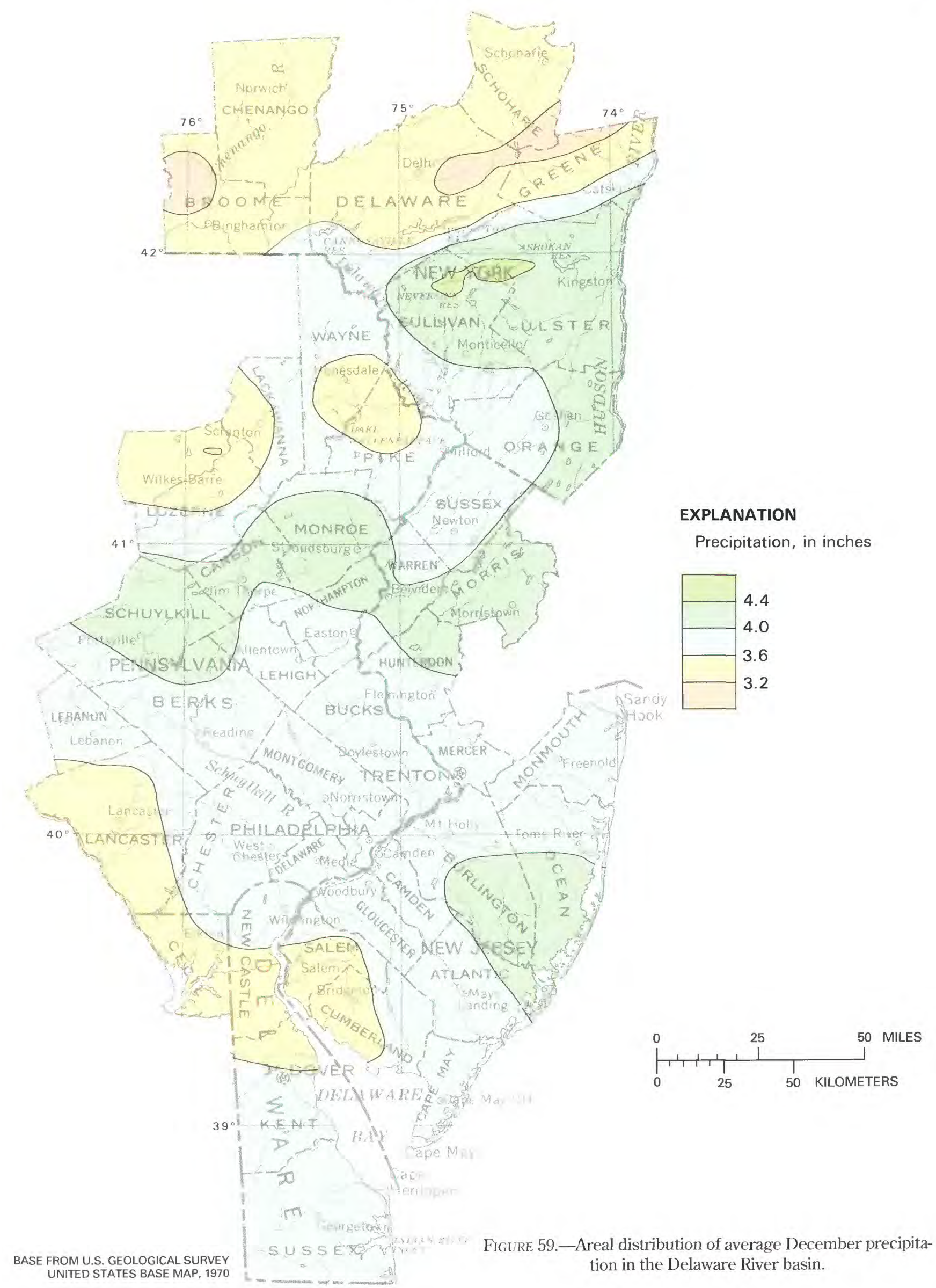


Average January precipitation totals range from 2.40 in. to $4.20 \mathrm{in}$. with the highest average values occurring in the northern part of the basin (figs. 60 and 61).

The annual time series plots (fig. 60) indicate great variability in individual monthly totals. At all stations, 1978 and 1979 stand out as the 2 years of maximum January precipitation. Persistent upper air flow during these months resulted in the steering of a series of cyclonic systems along the Atlantic Coast. Warm, moist air moving over the Atlantic Ocean surface clashed with cold continental air to produce record snowfall and precipitation amounts along the East Coast.
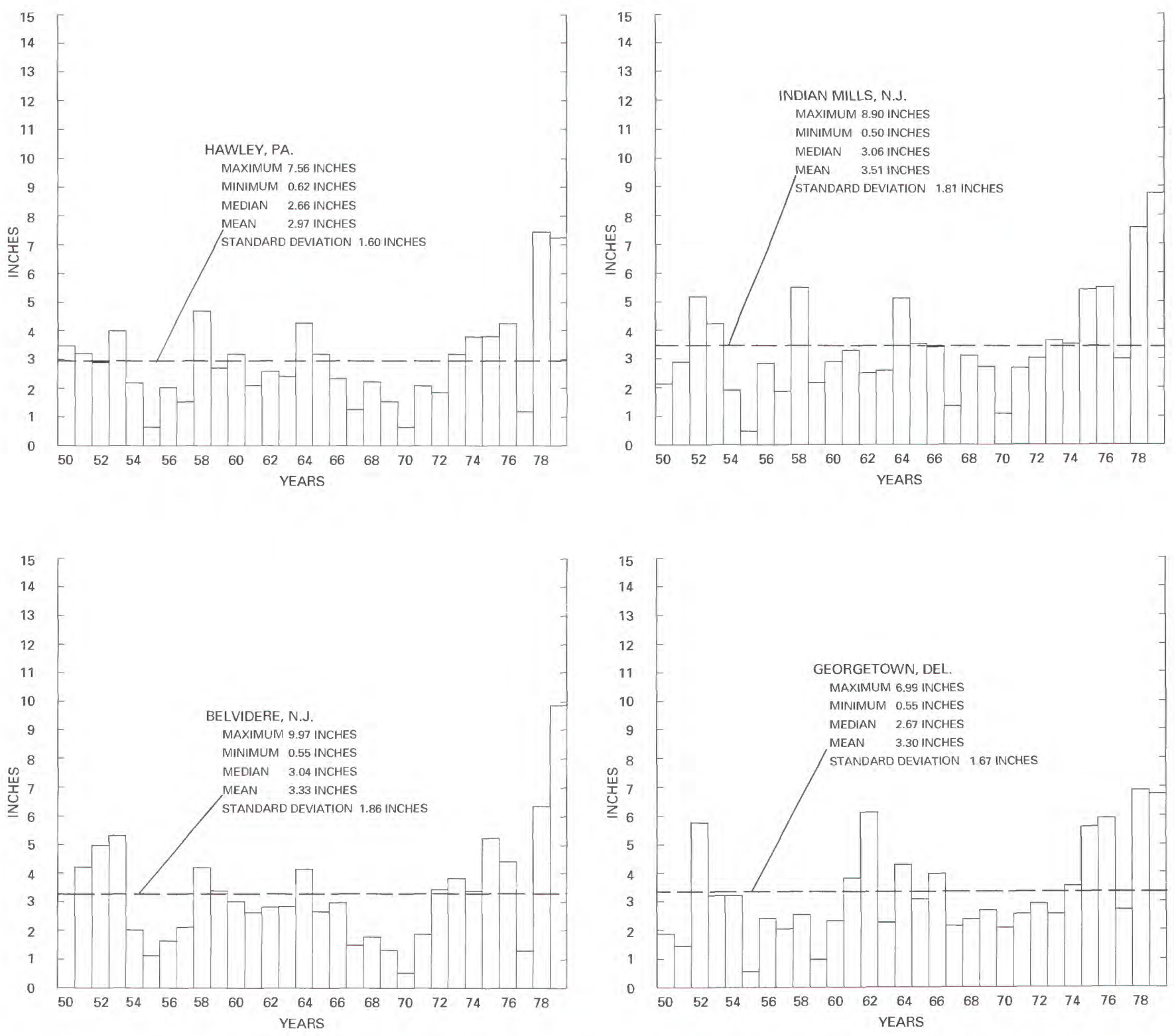

Figitike 60--Average January precipitation at four stations in the Delaware River basin, 1950-79. 


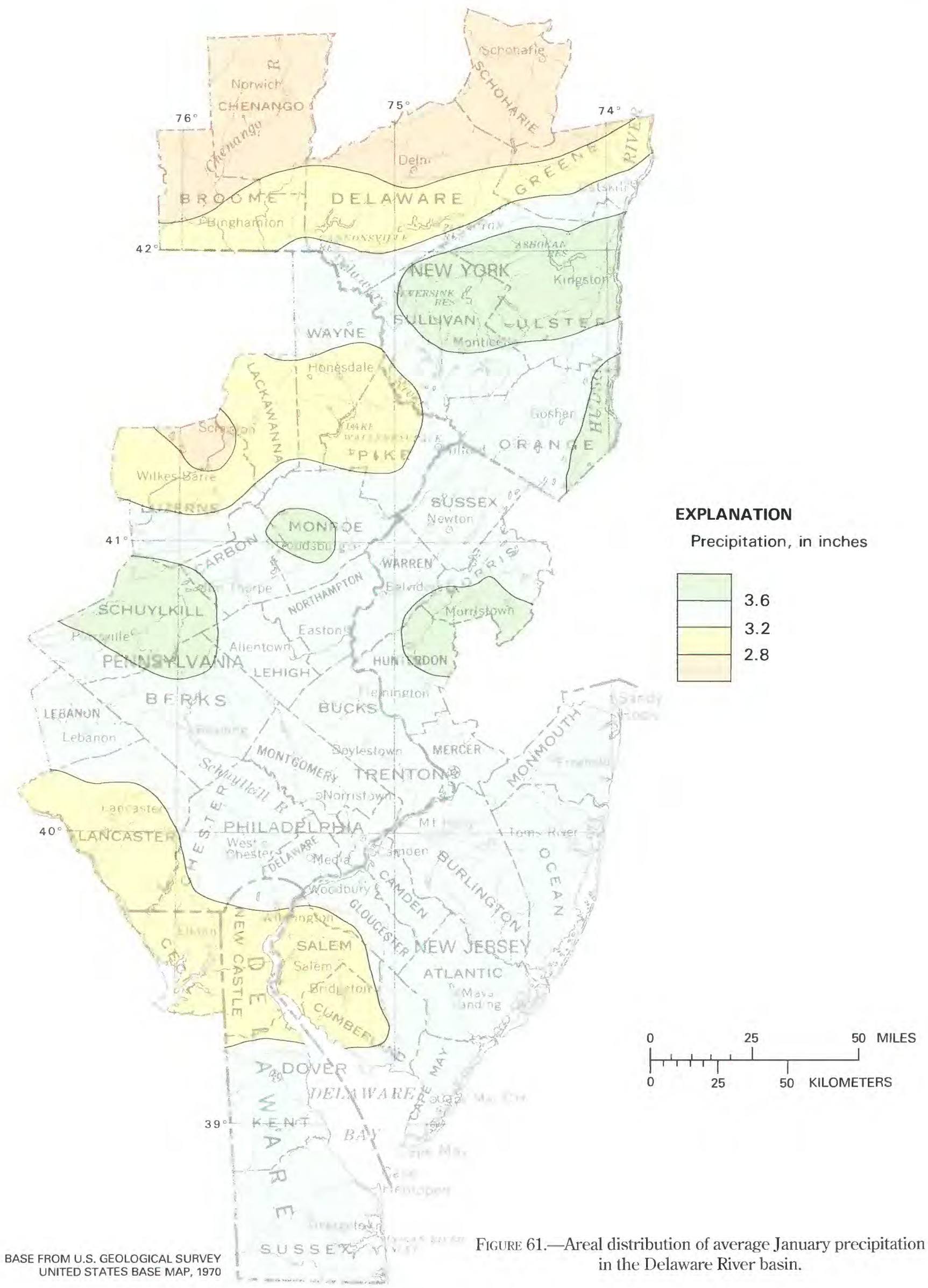


Average February precipitation values range from 2.30 in. to 3.70 in. (figs. 62 and 63 ), with the higher values occurring along the eastern margin of the basin.
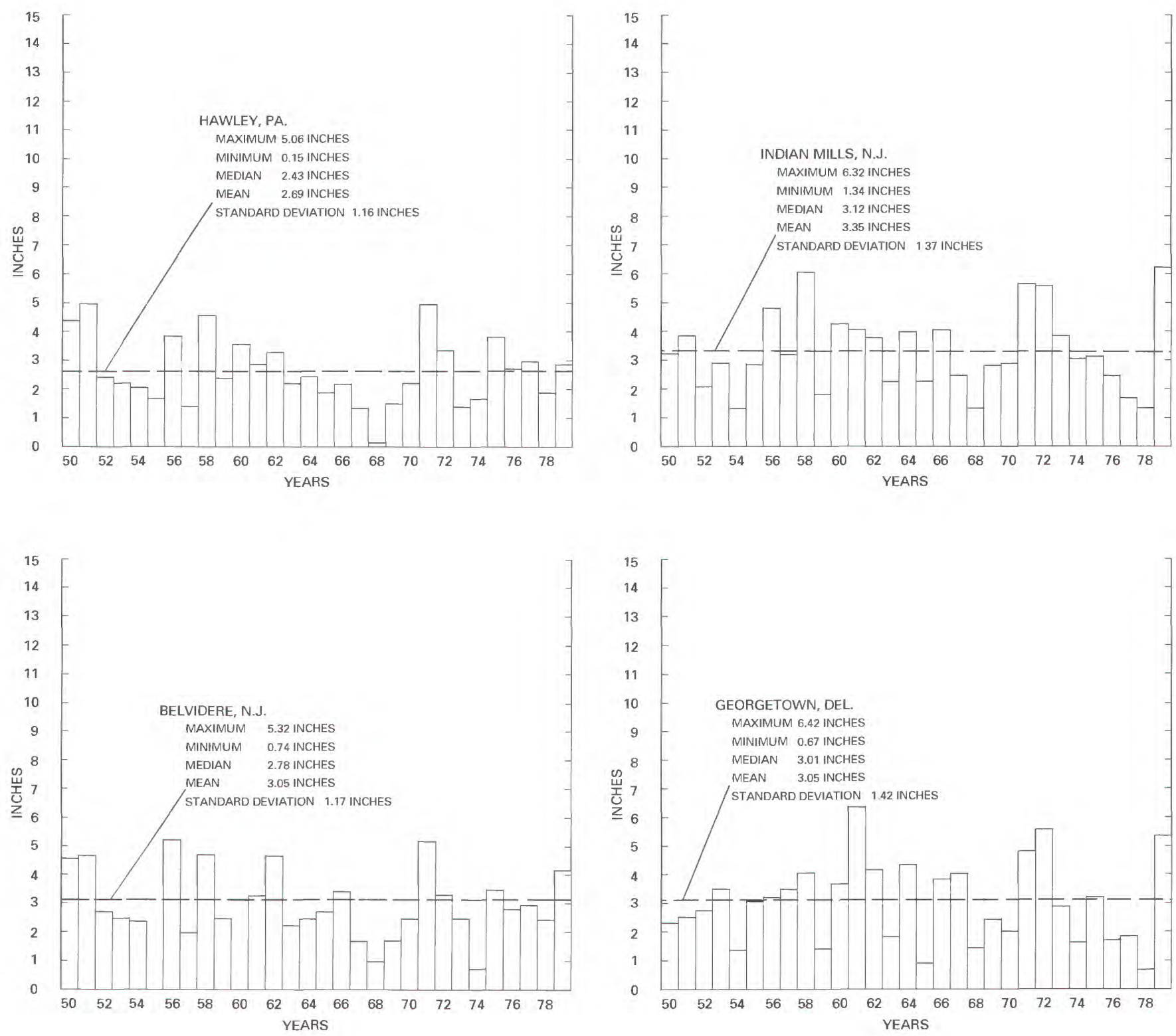

Figure 62.-Average February precipitation at four stations in the Delaware River basin, 1950-79. 


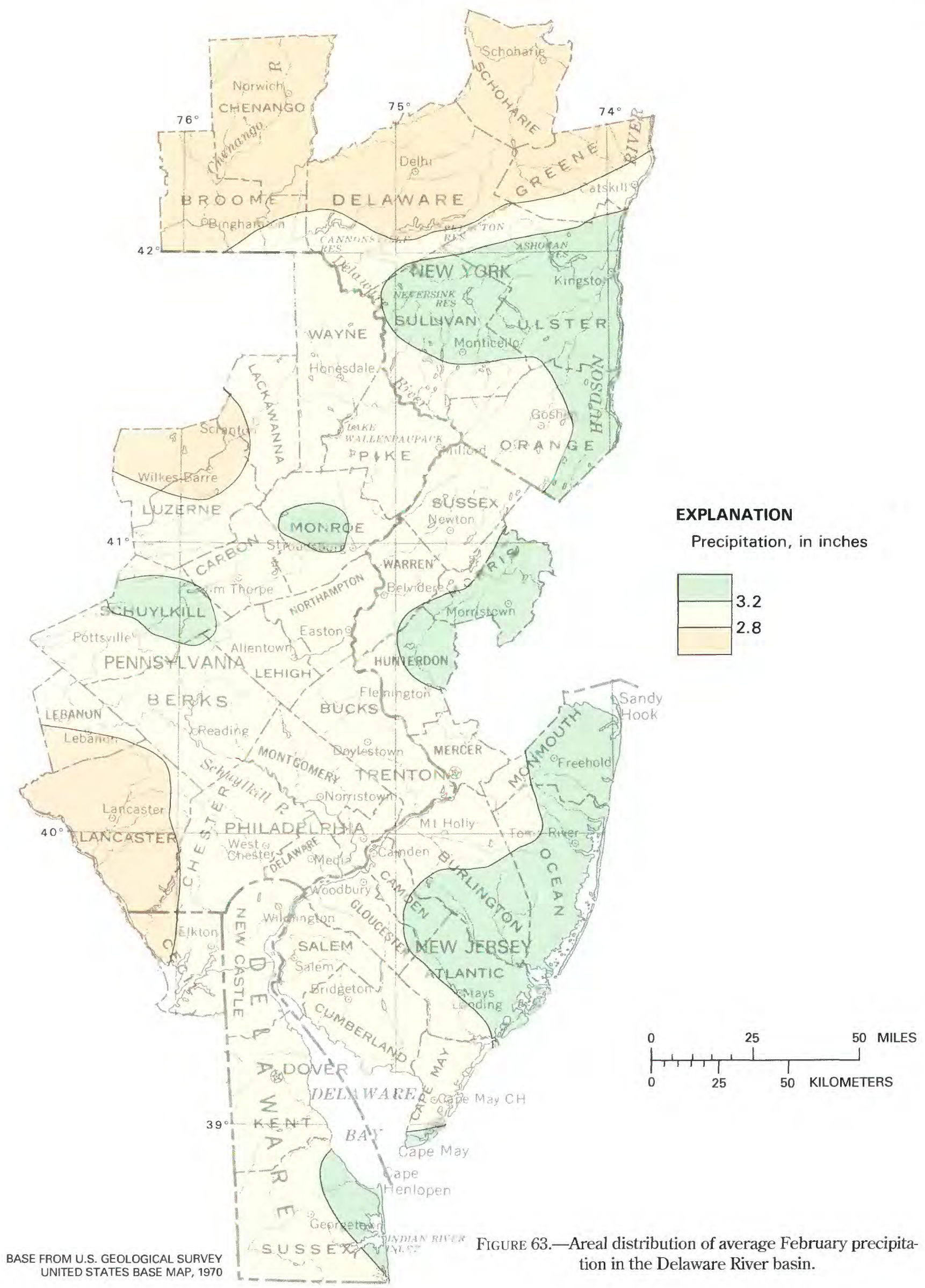



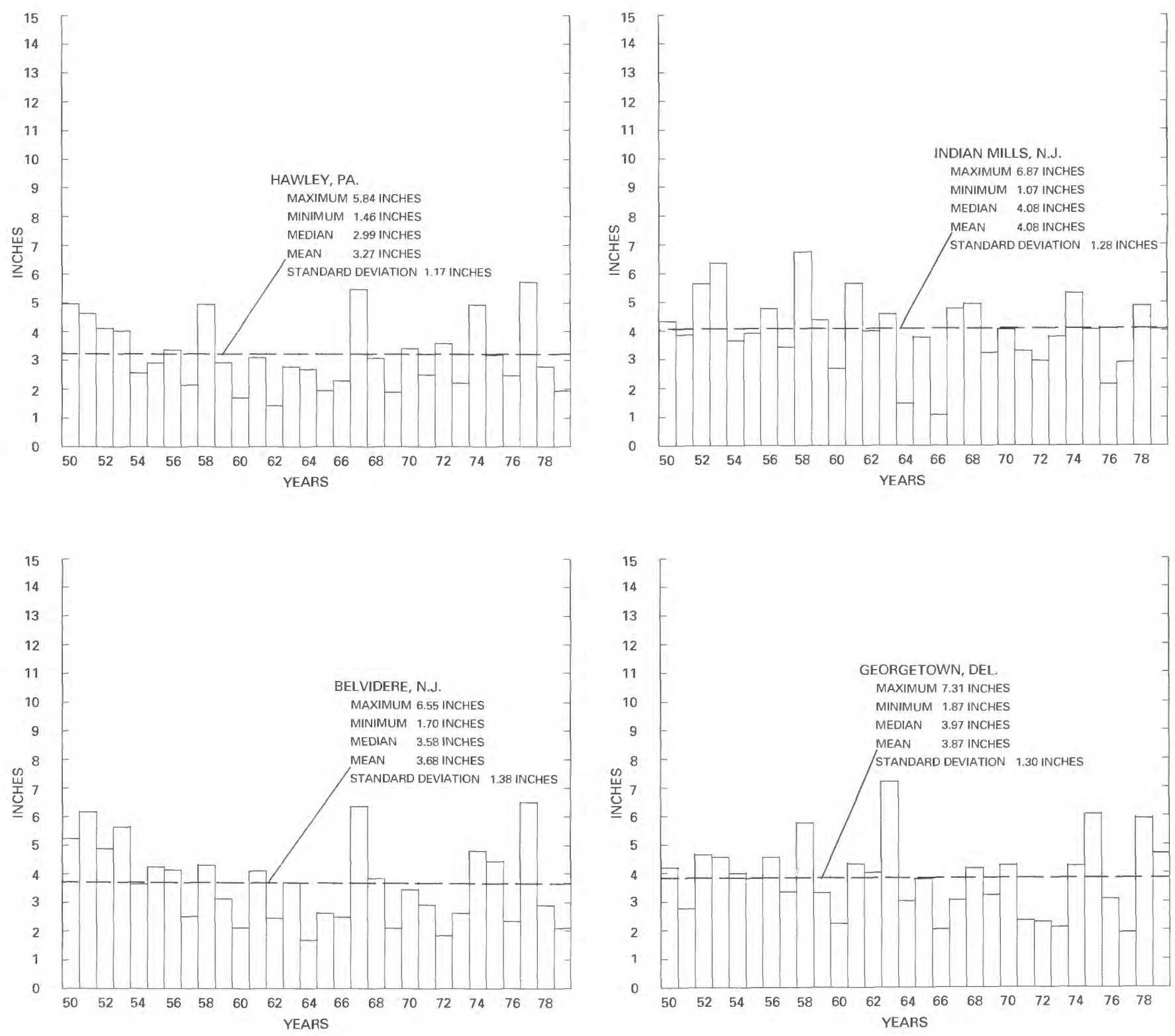

Figure 64.-Average March precipitation at four stations in the Delaware River basin, 1950-79. 


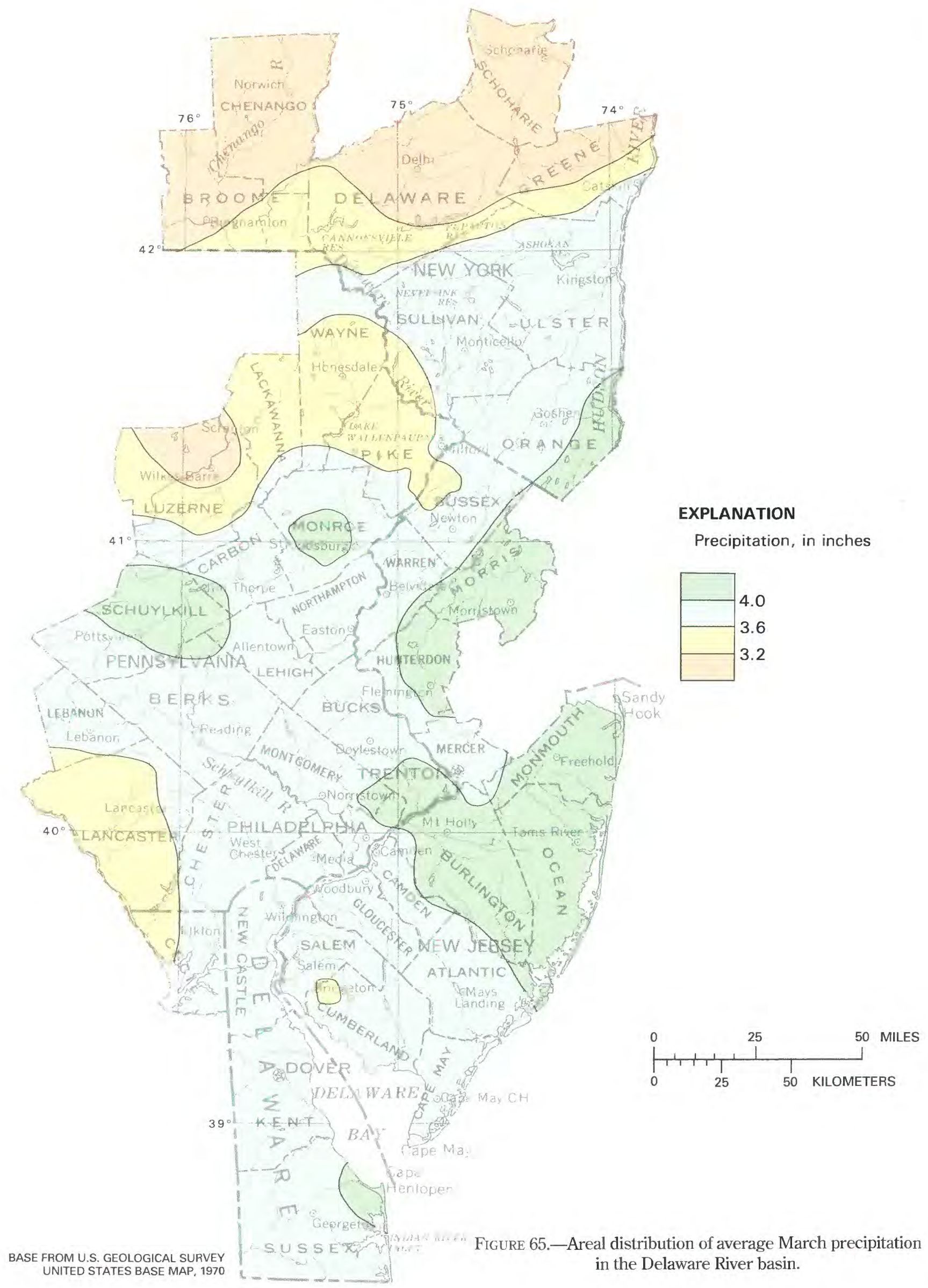



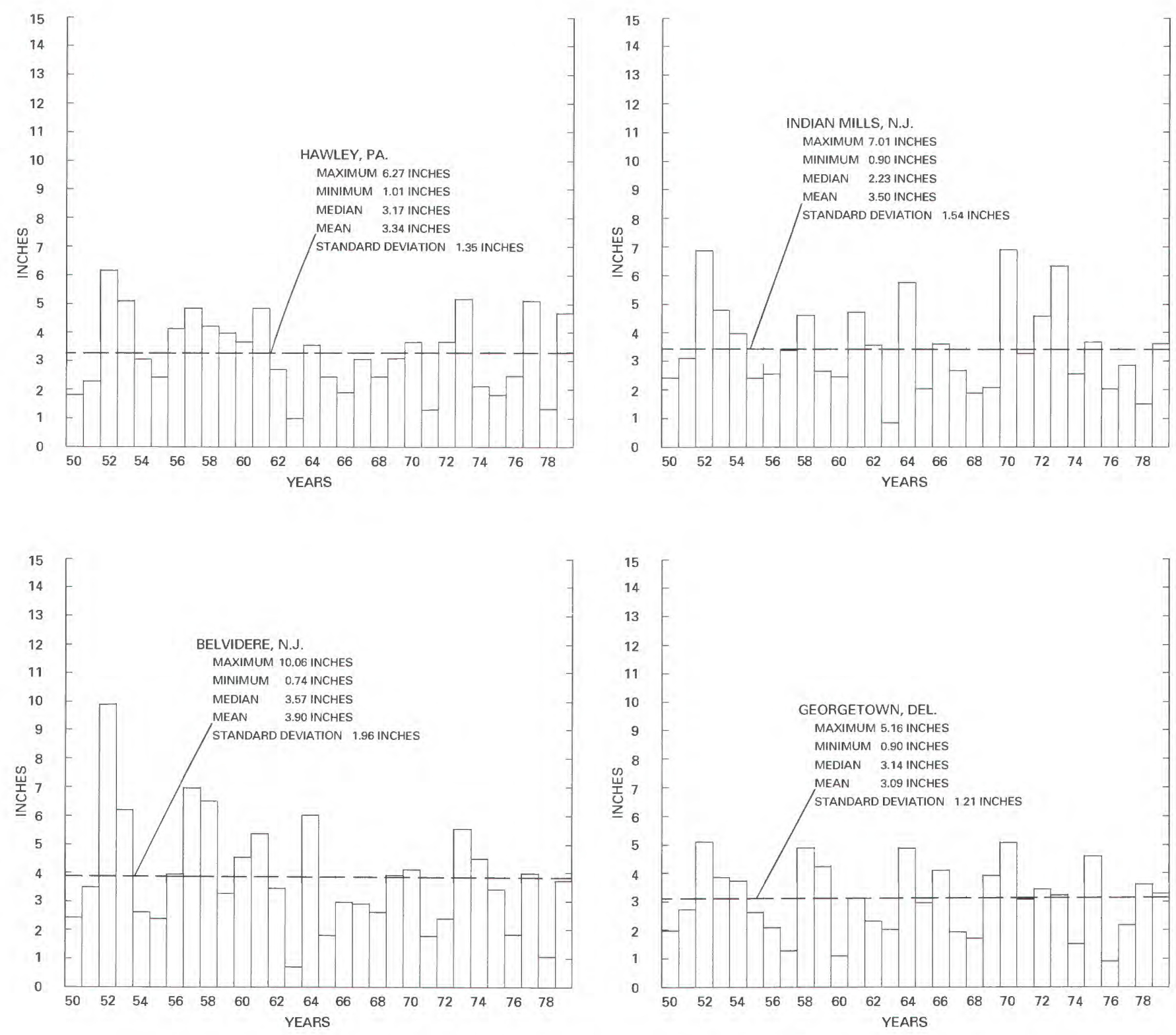

FIGURE 66.-Average April precipitation at four stations in the Delaware River basin, 1950-79. 


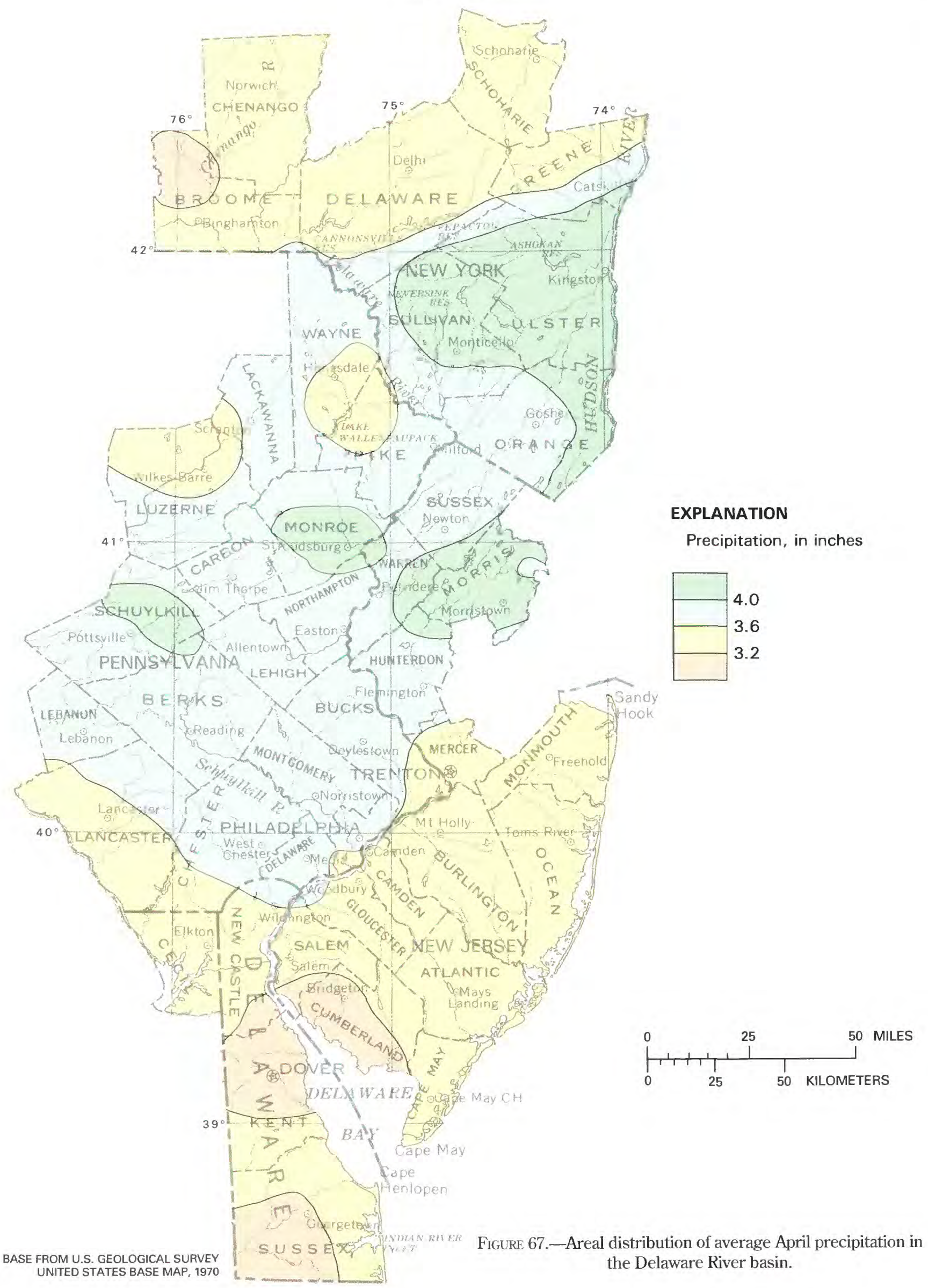


Average May precipitation totals range from $3.10 \mathrm{in}$. to 3.6 in. in the central and eastern portions of the basin (figs. 68 and 69).
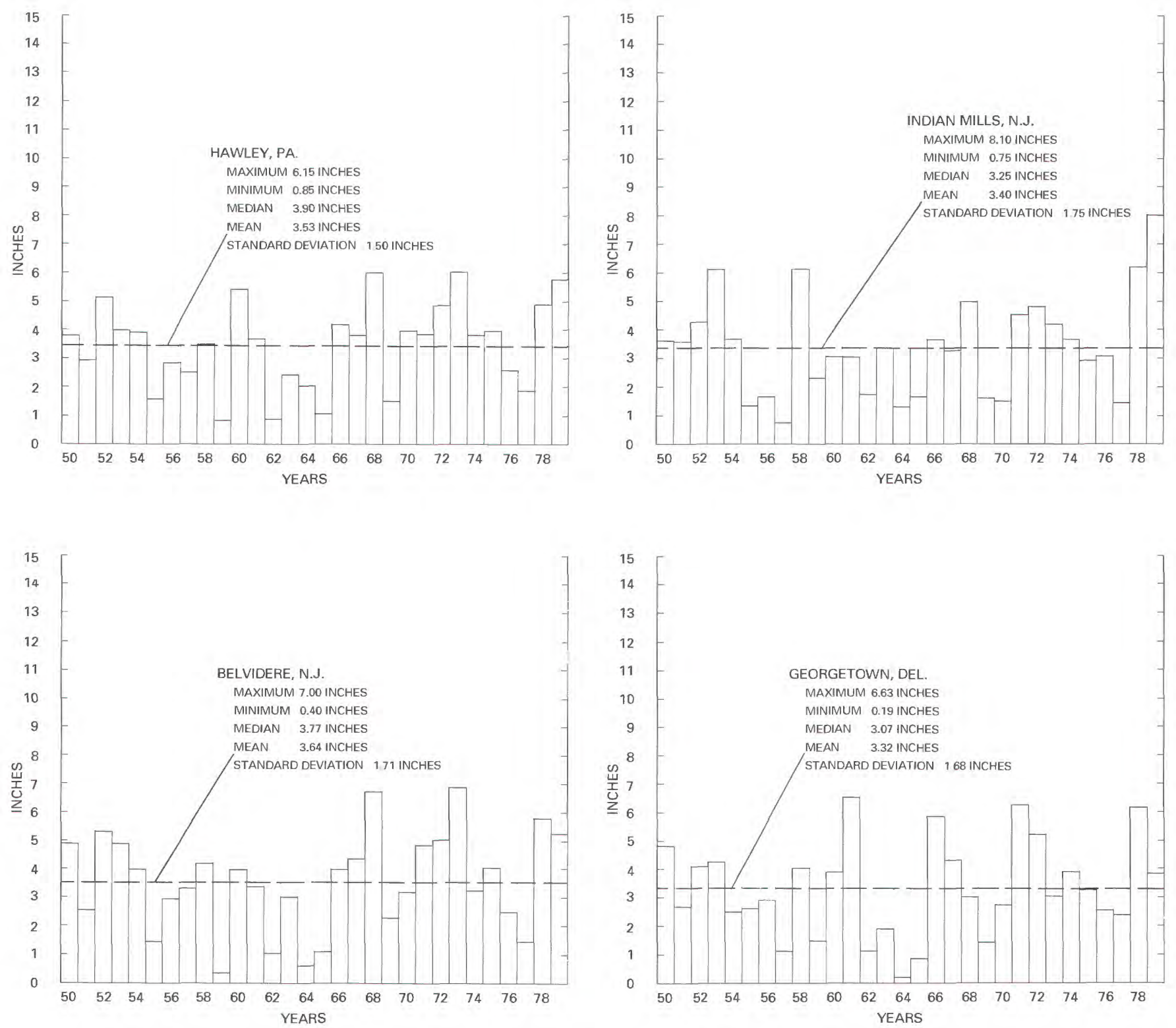

FIGURE 68.-Average May precipitation at four stations in the Delaware River basin, 1950-79. 


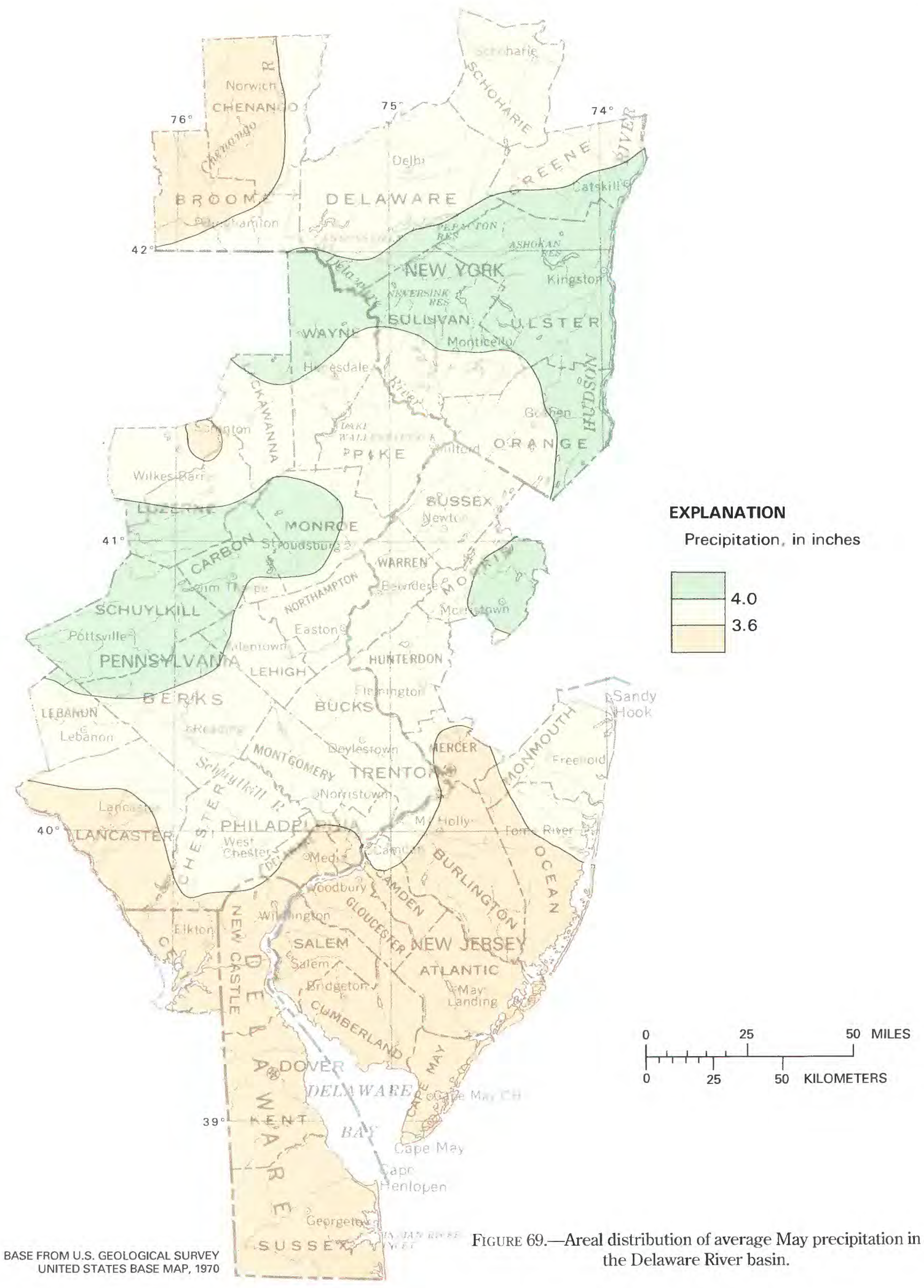



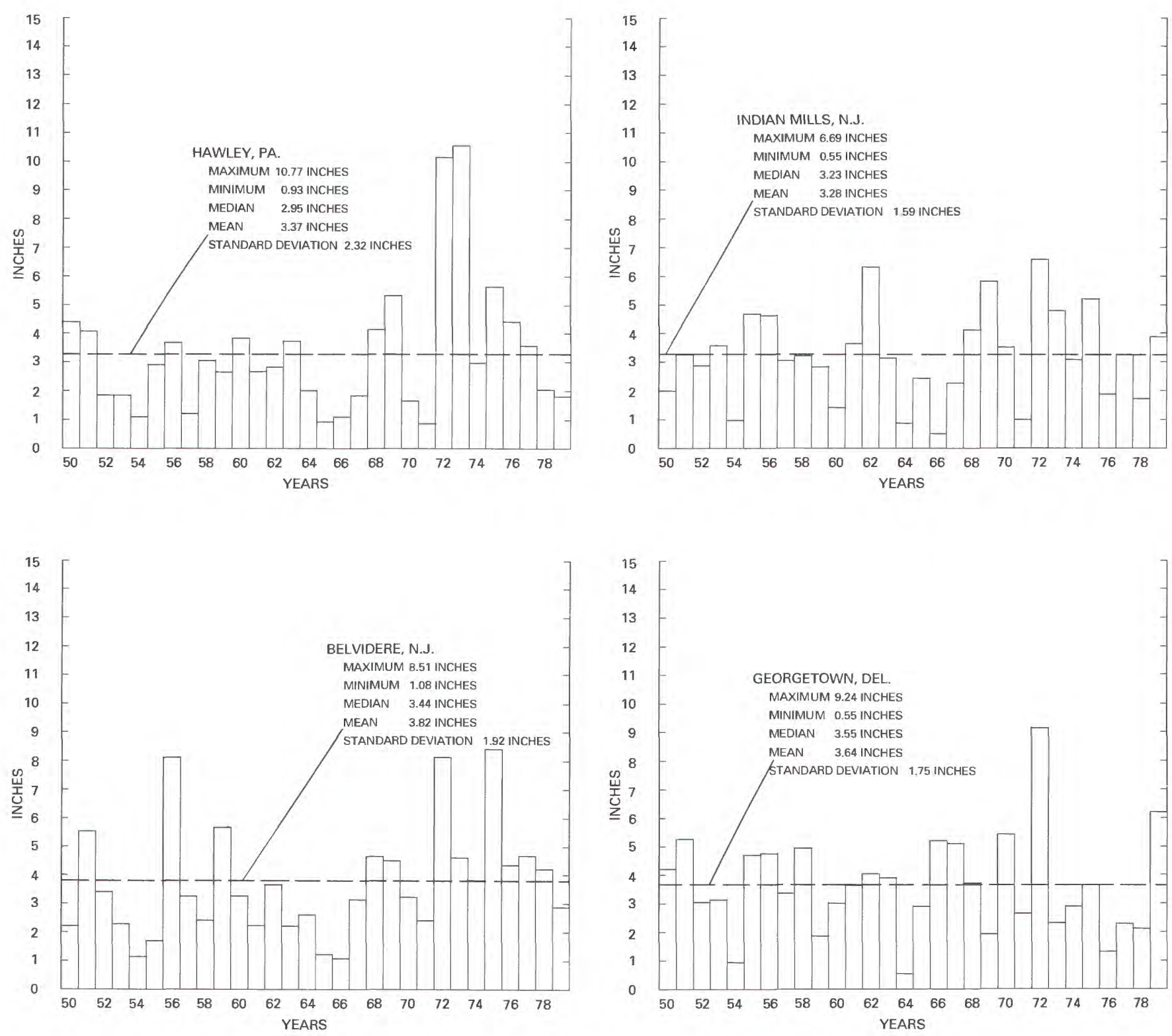

FiguRE 70.-Average June precipitation at four stations in the Delaware River basin, 1950-79. 


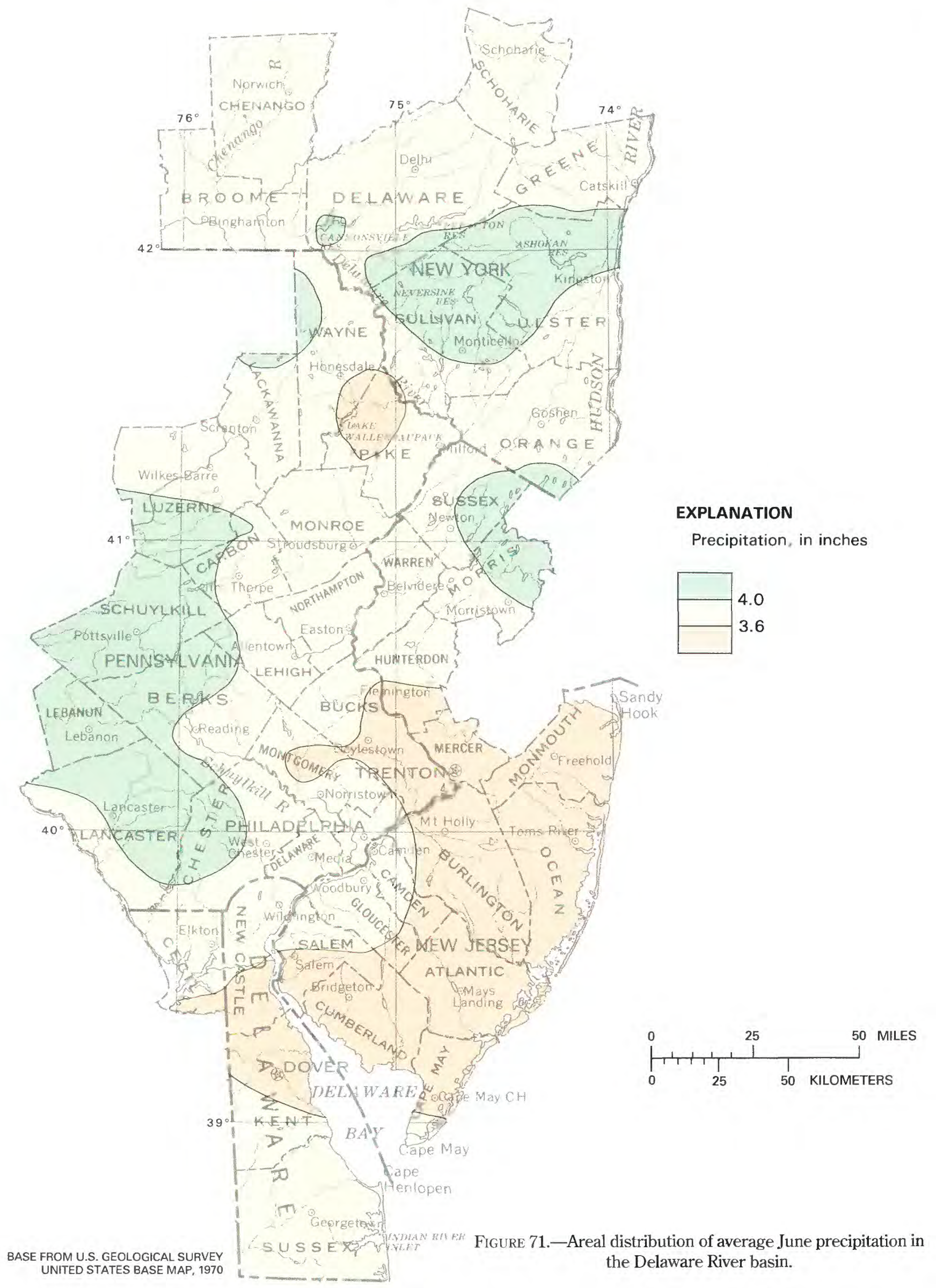



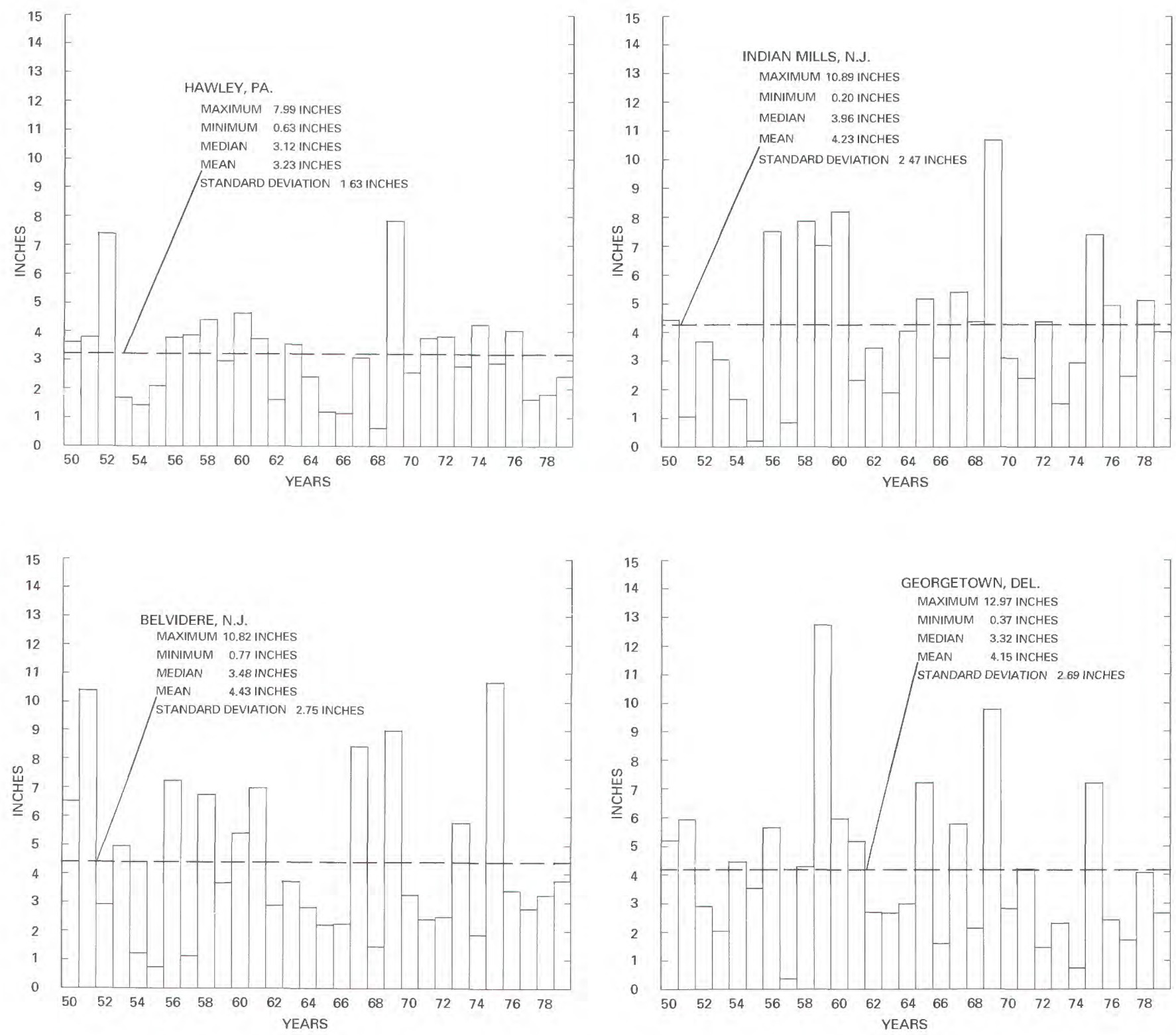

FIGLRE 72.-Average July precipitation at four stations in the Delaware River basin, 1950-79. 


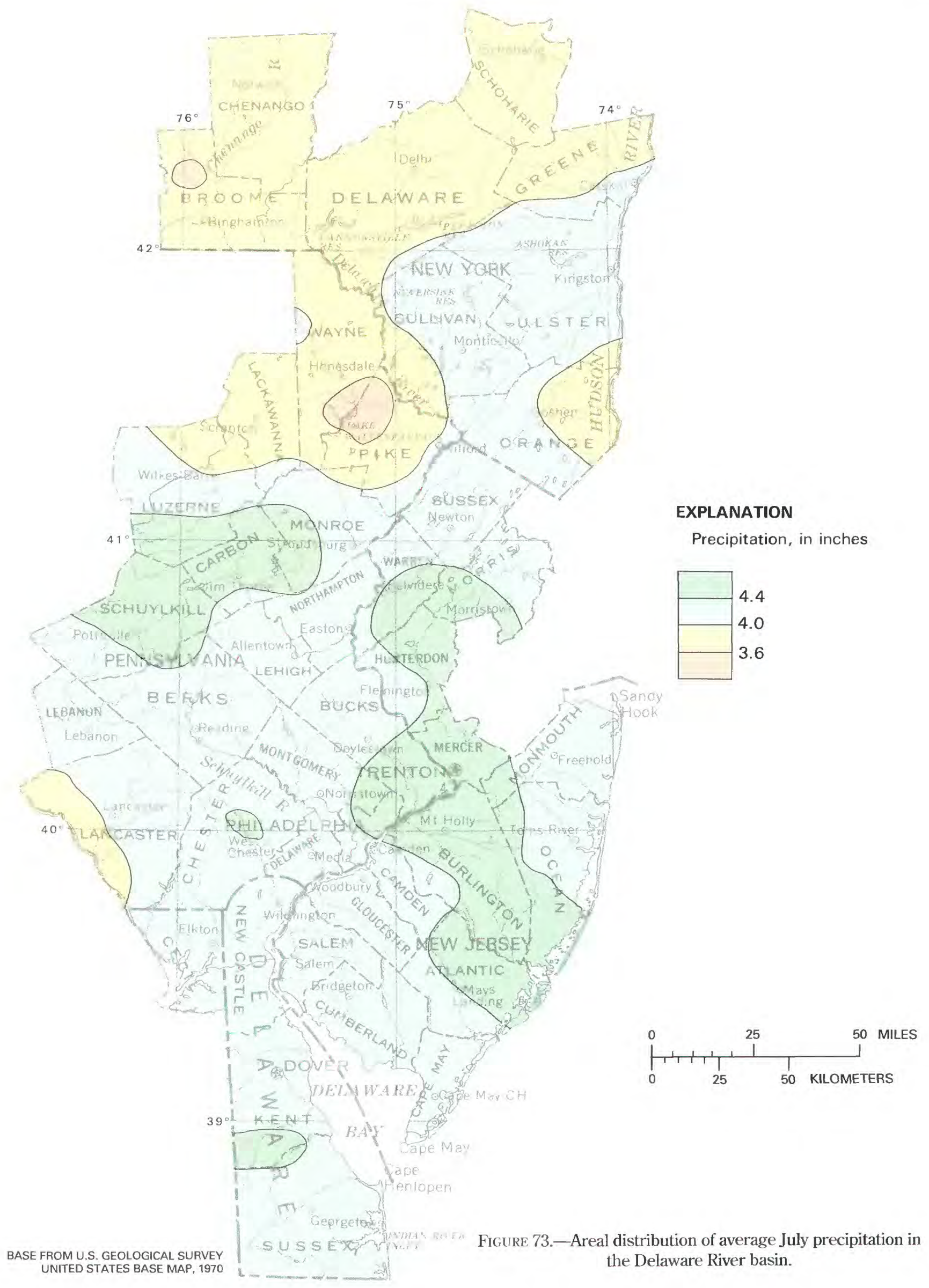



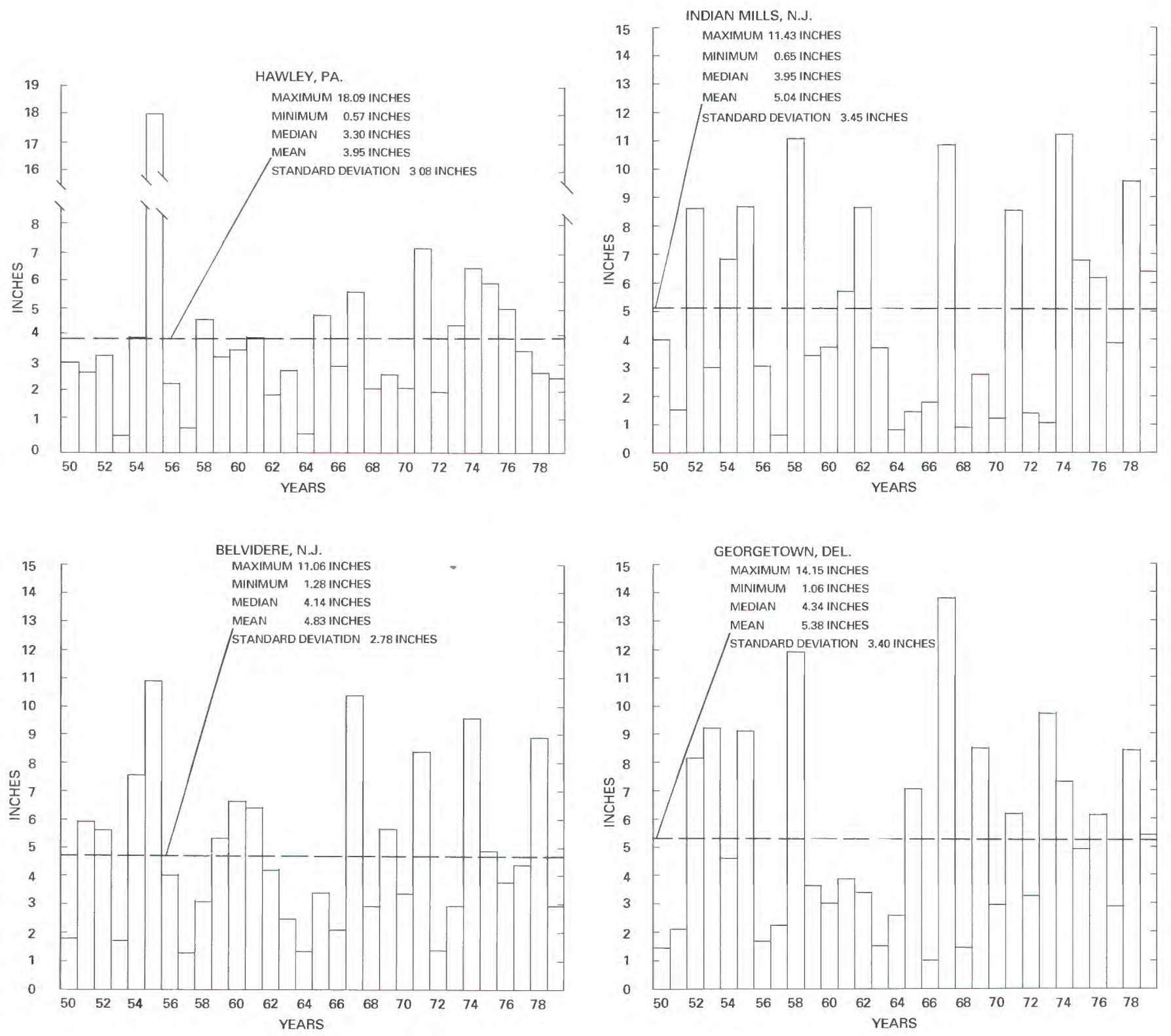

Figure 74.-Average August precipitation at four stations in the Delaware River basin, 1950-79. 


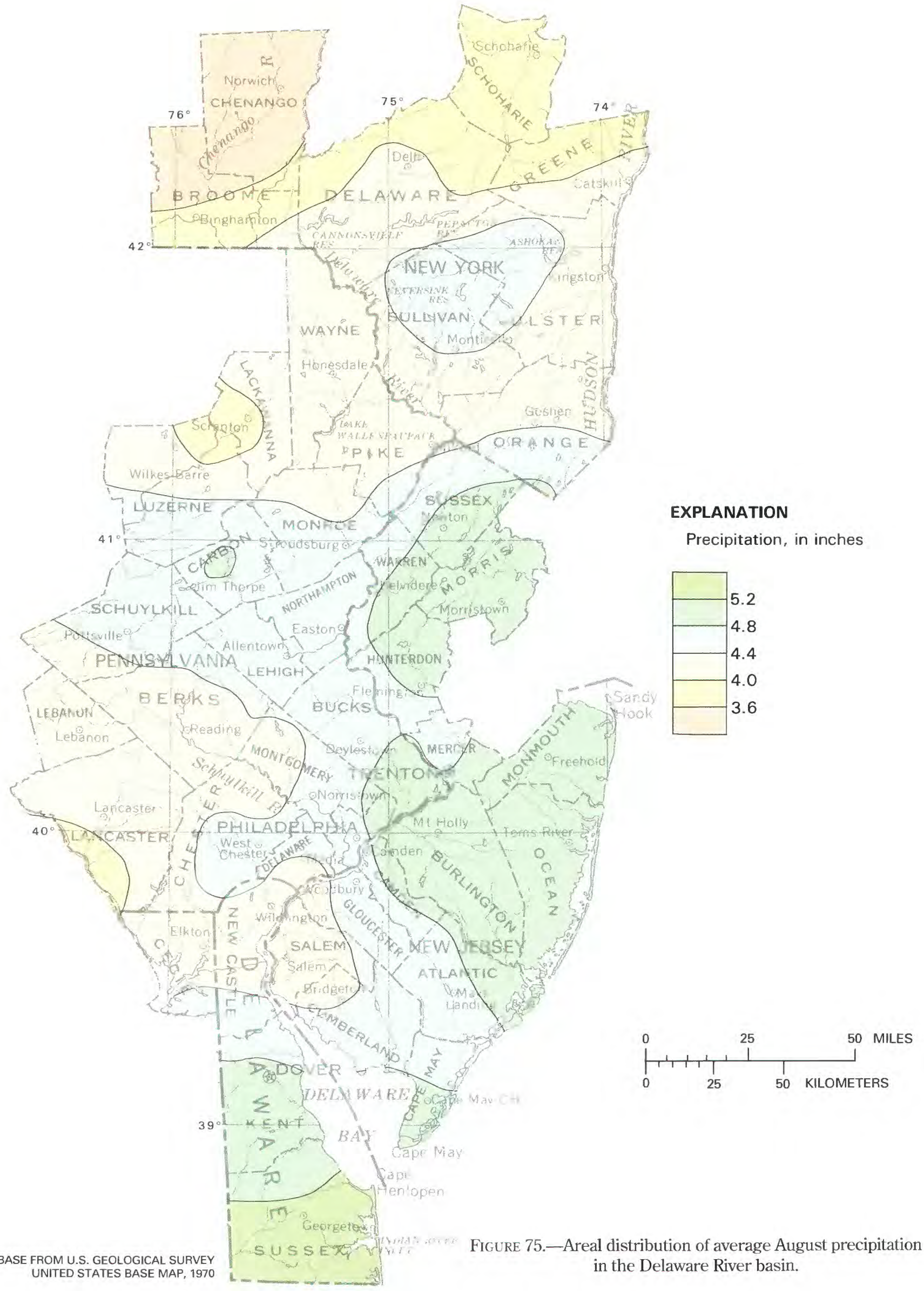



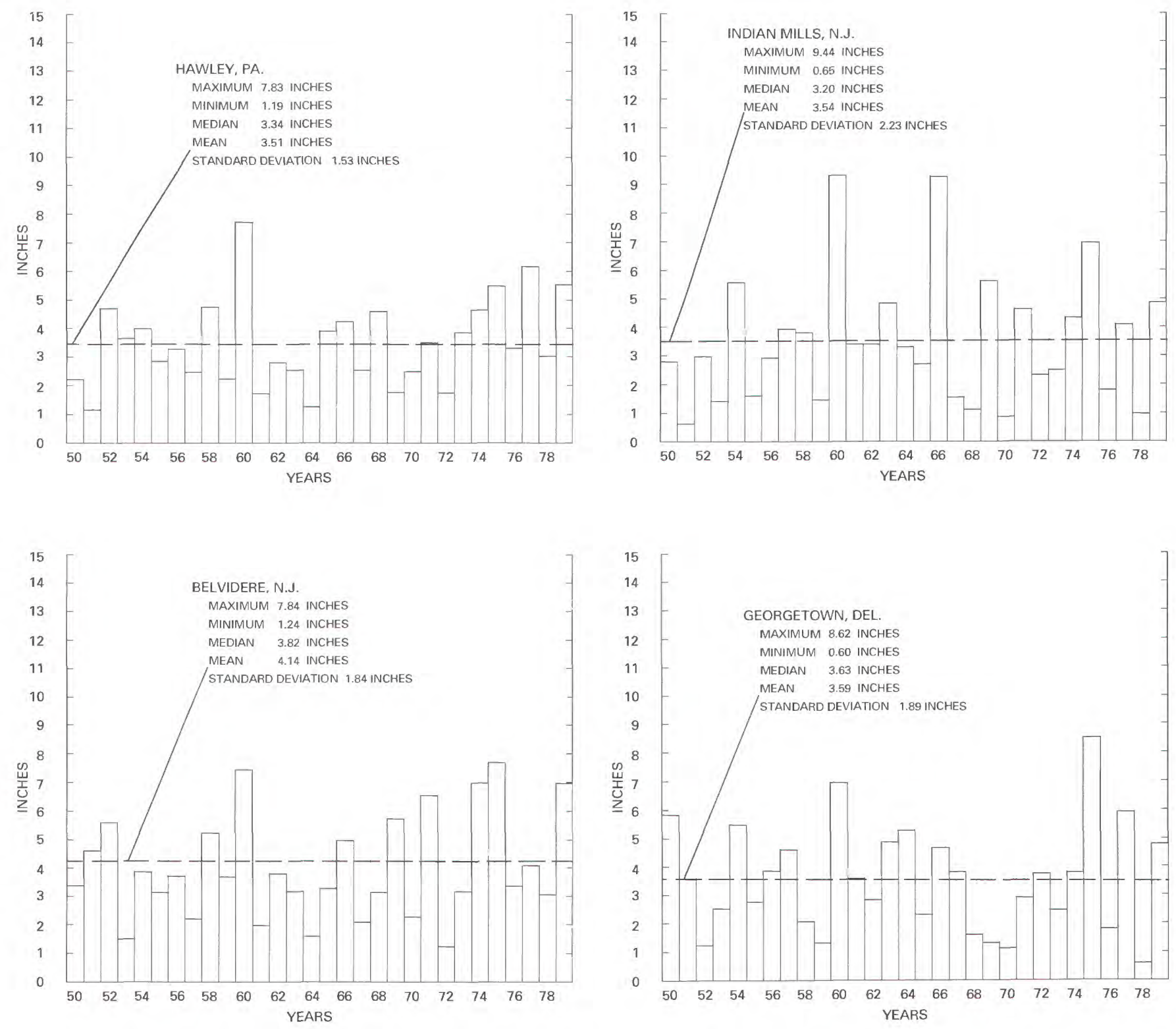

Fig RE 76.-Average September precipitation at four stations in the Delaware River basin, 1950-79. 


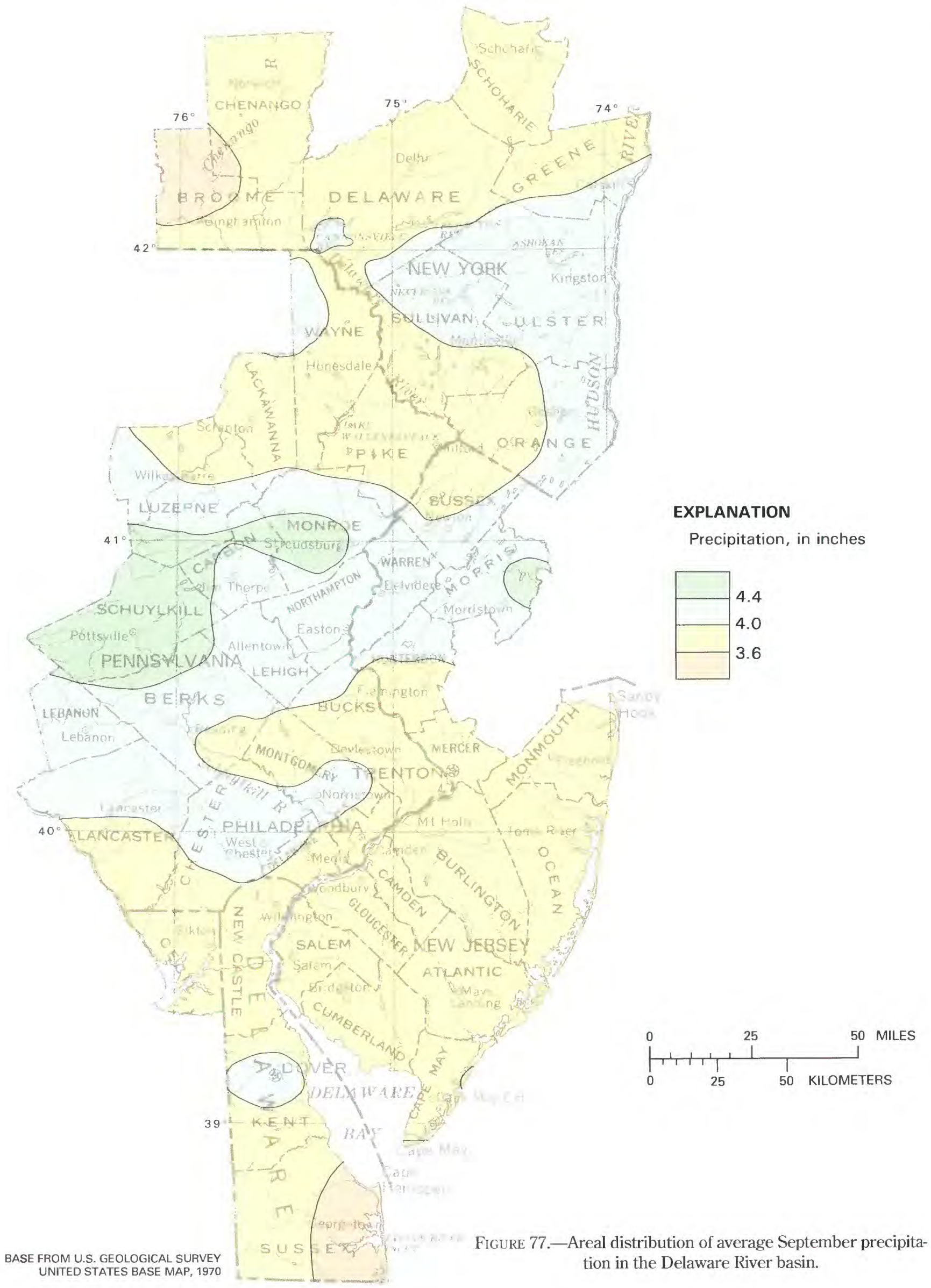




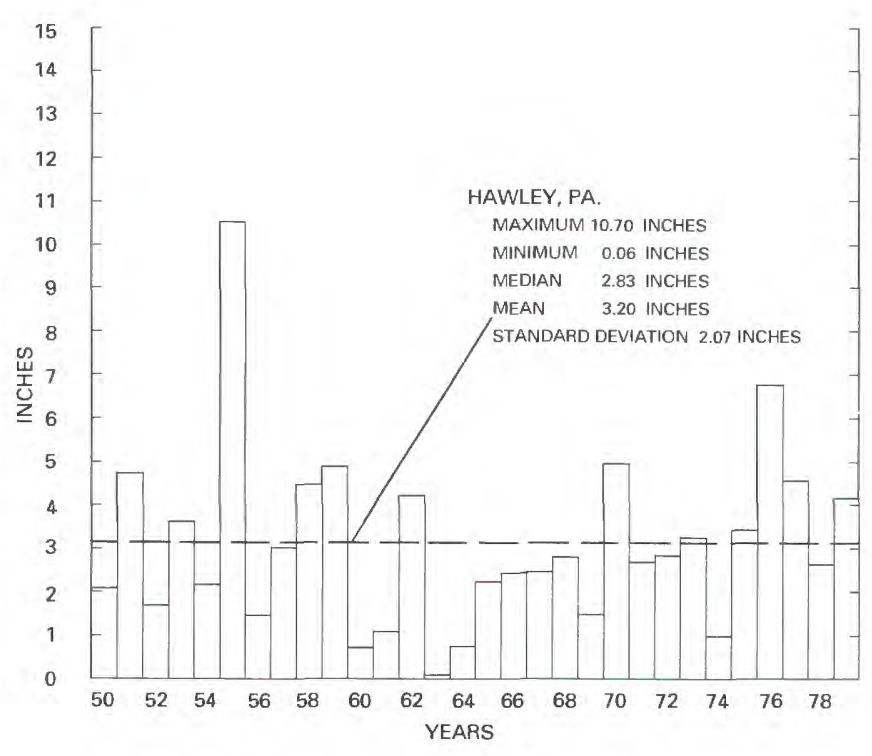

Average October precipitation values range from 2.58 in. to 4.59 in. (figs. 78 and 79).

October 1963 was a dry month throughout the Delaware River basin. During that month, the 700-millibar heights were above normal, and minimal air flowed into the area from the Gulf of Mexico-the normal source of moist air during October (Green, 1964).
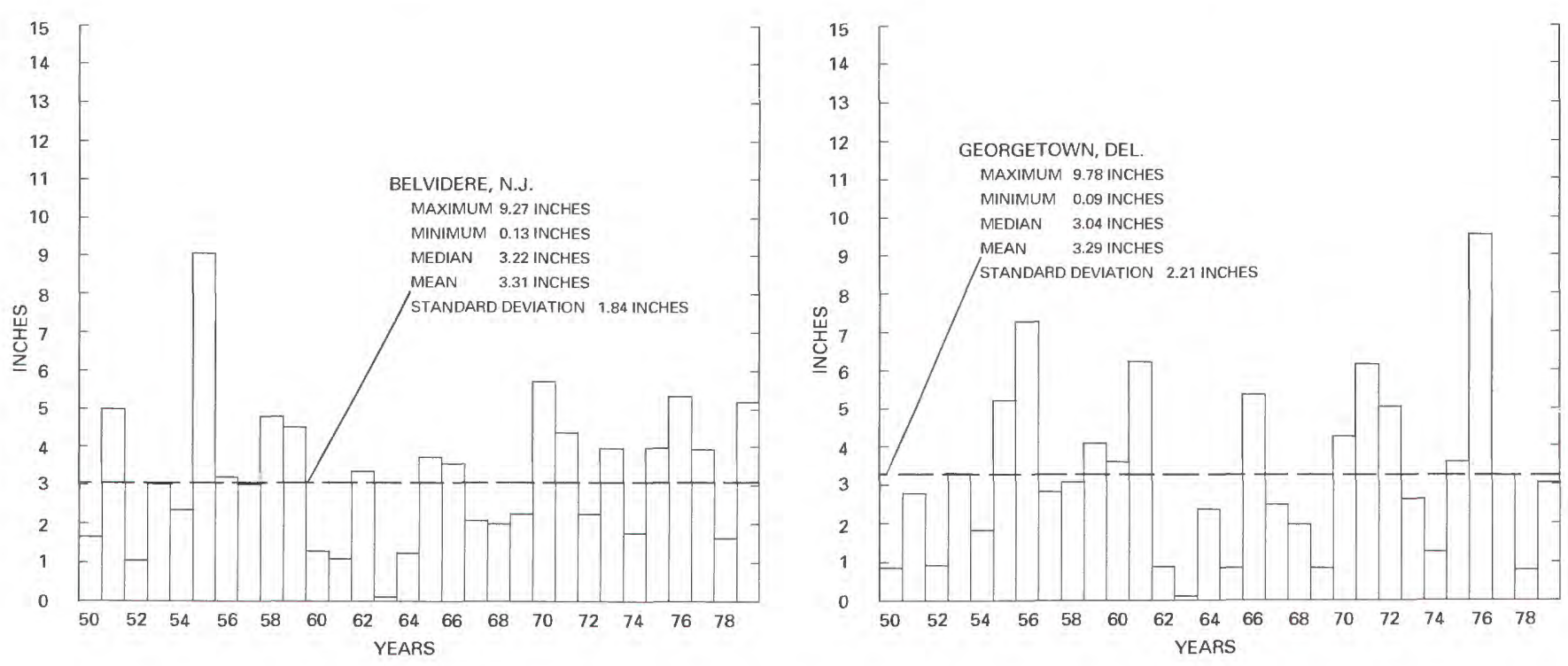

Figure 78.-Average October precipitation at four stations in the Delaware River basin, 1950-79. 


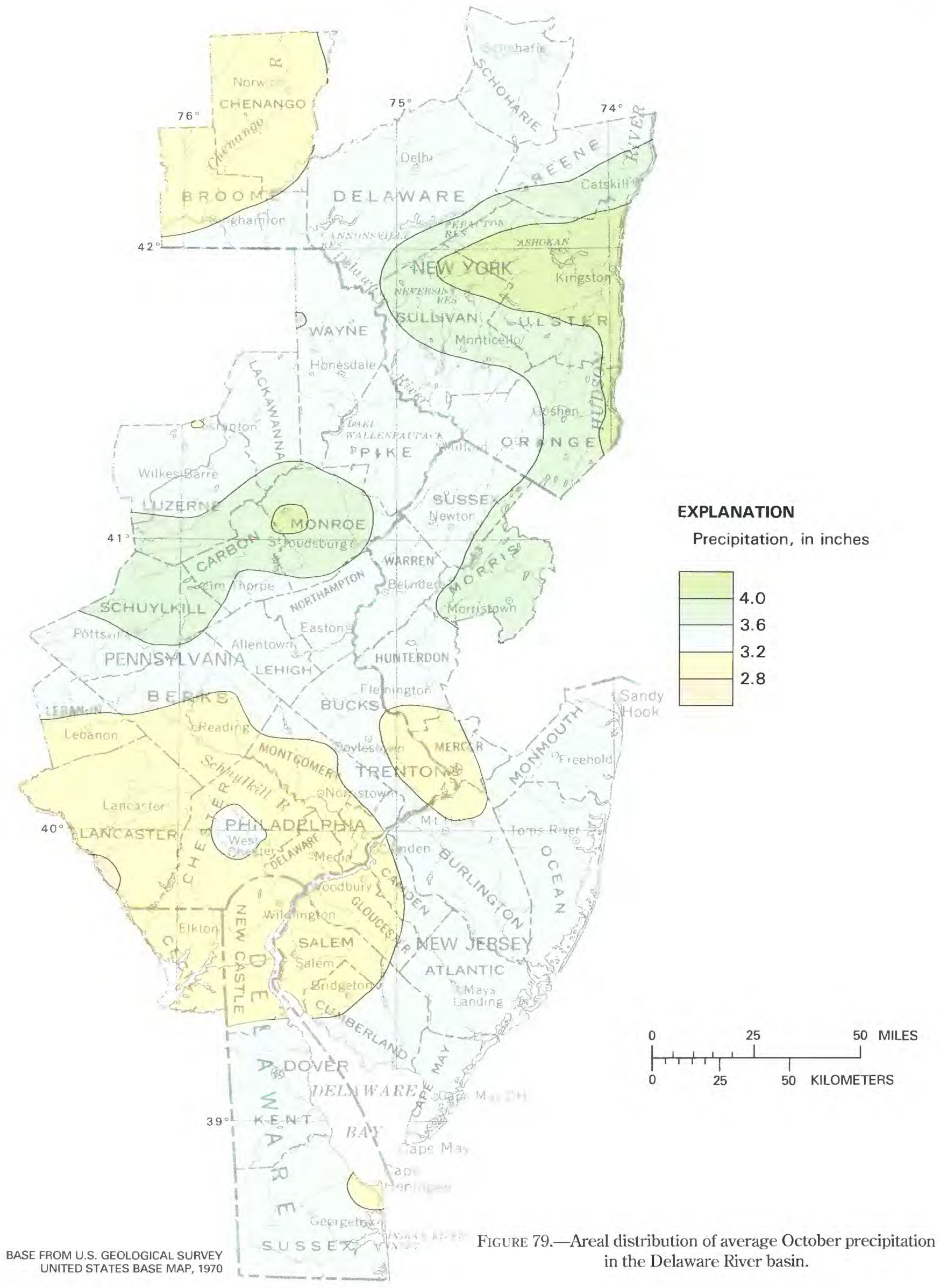



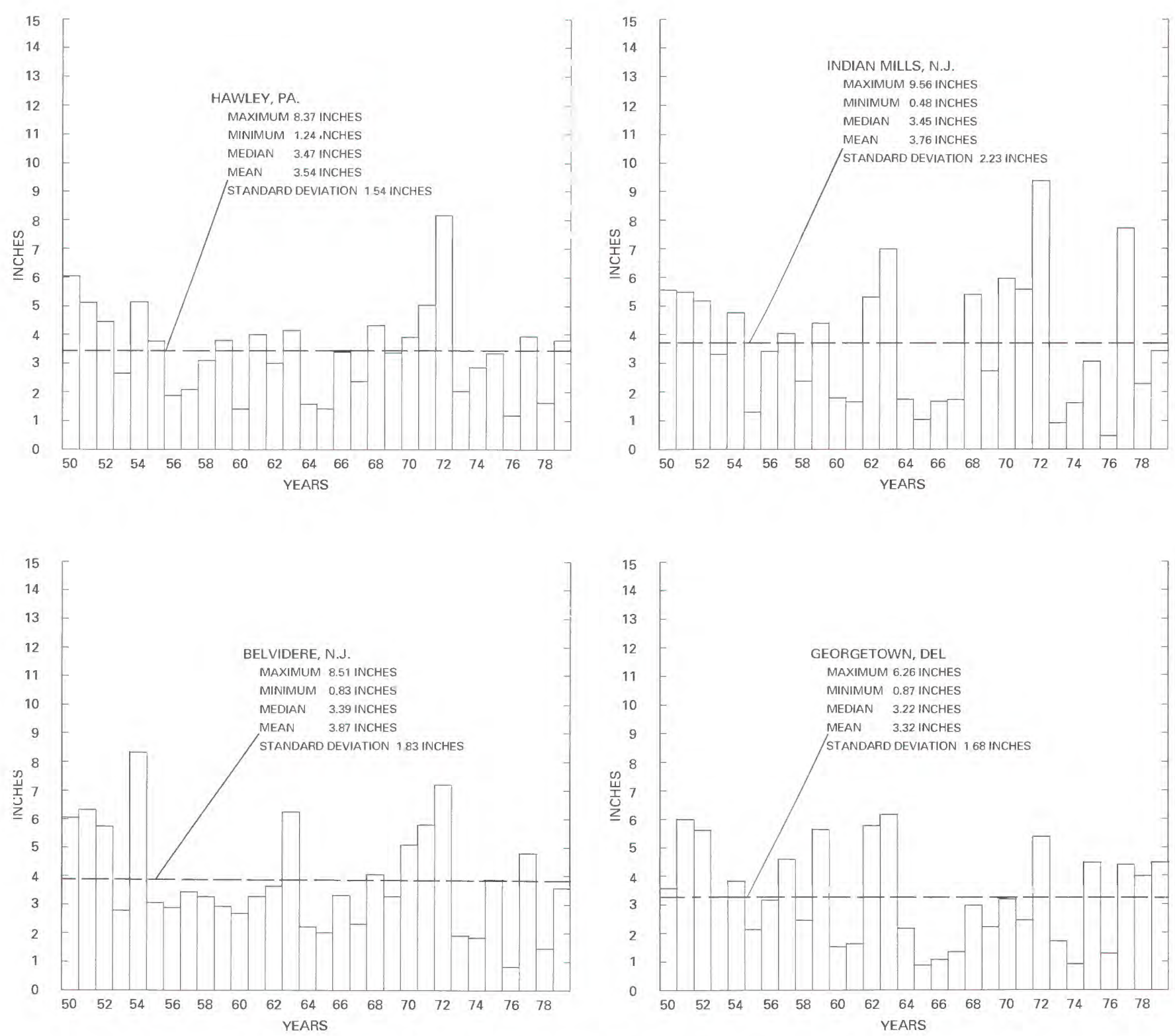

Figure 80.-Average November precipitation at four stations in the Delaware River basin, 1950-79. 


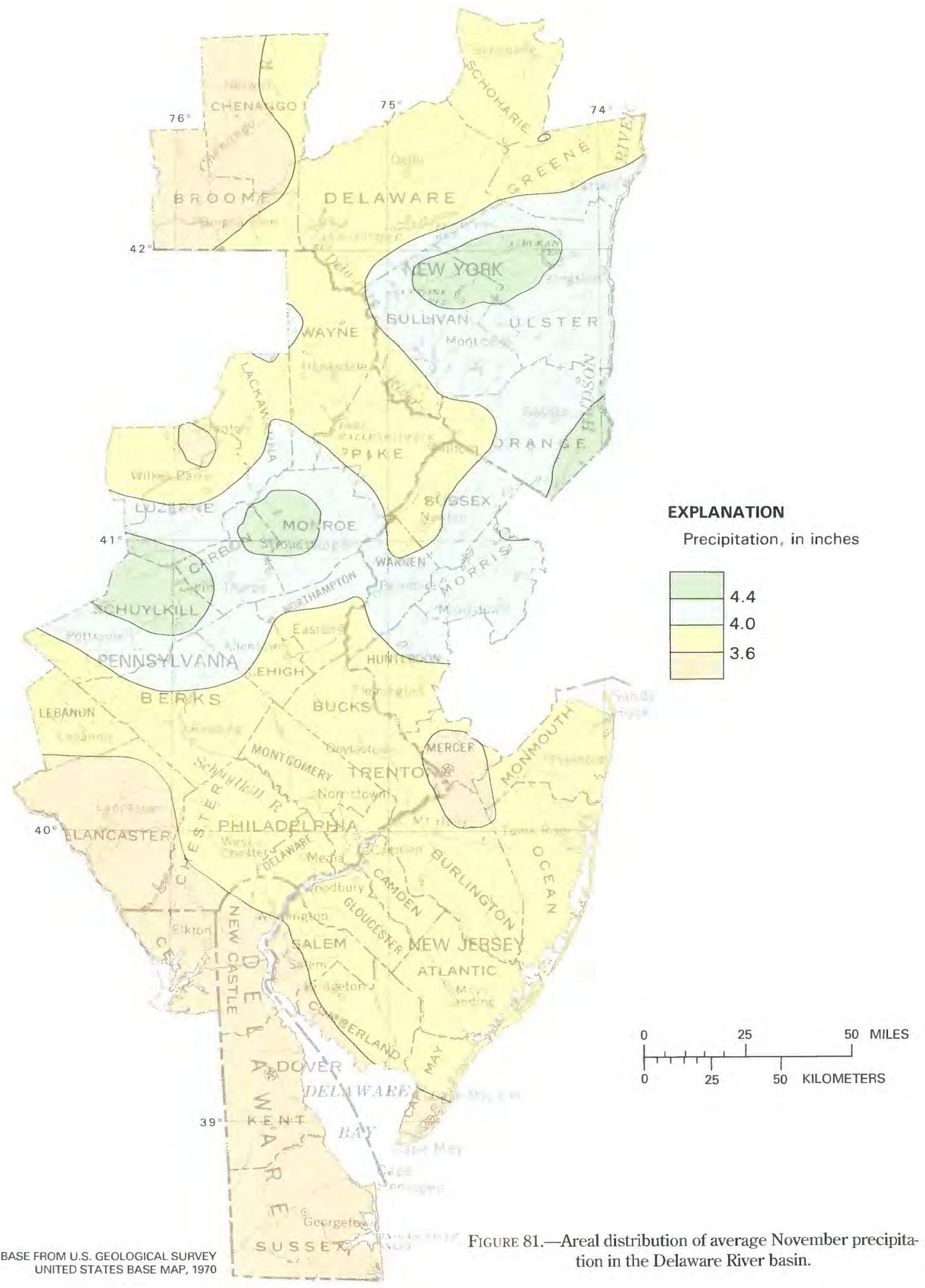



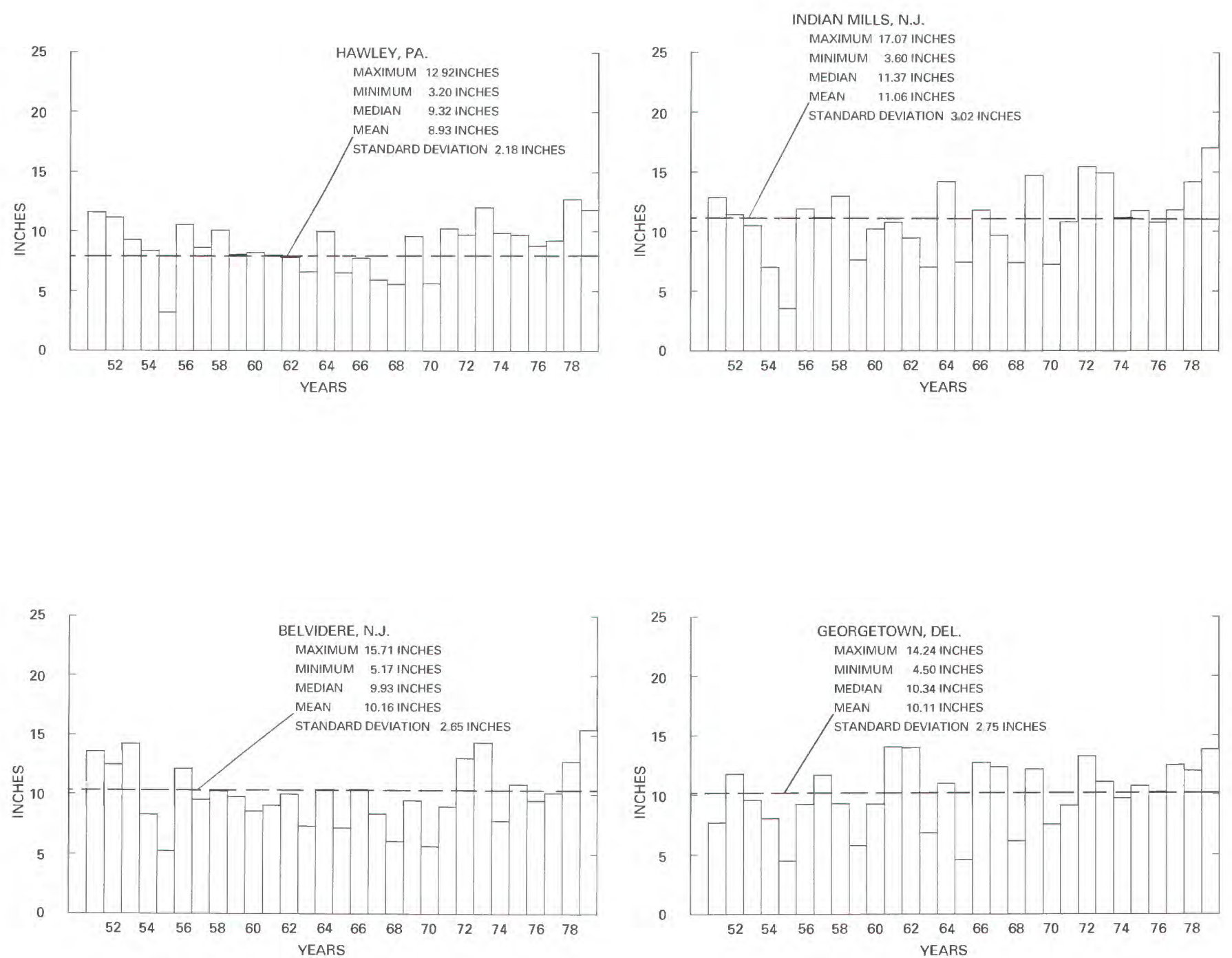

FiguRE 82.-Average winter (December-February) precipitation at four stations in the Delaware River basin, 1950-79. 


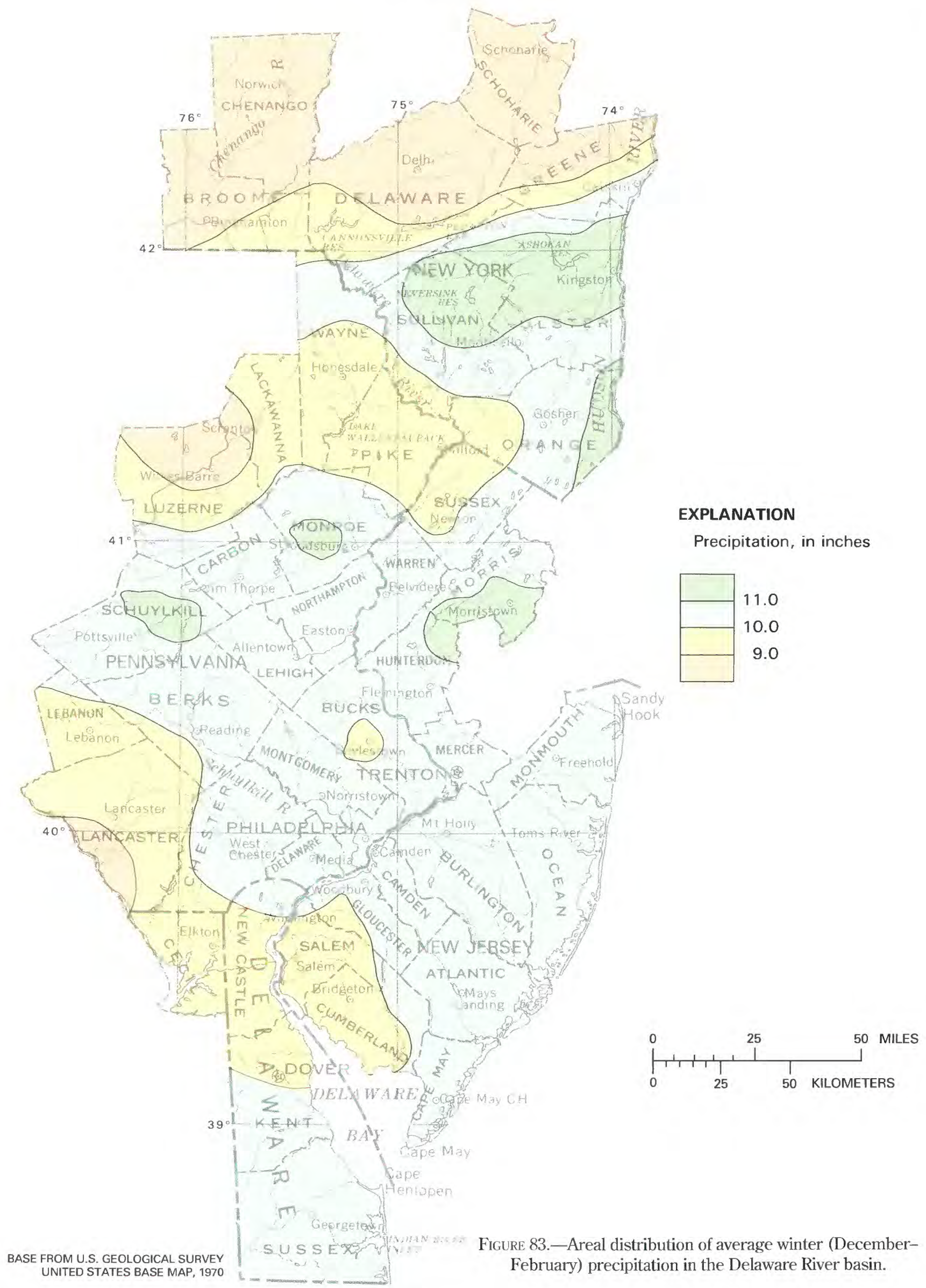




\section{AVERAGE SPRING PRECIPITATION}

Average spring (March-May) precipitation ranges from $9.01 \mathrm{in}$. to $13.55 \mathrm{in}$., with the highest values in the central and eastern parts of the basin (figs. 84 and 85).

Time series plots of spring precipitation are shown in figure 84.
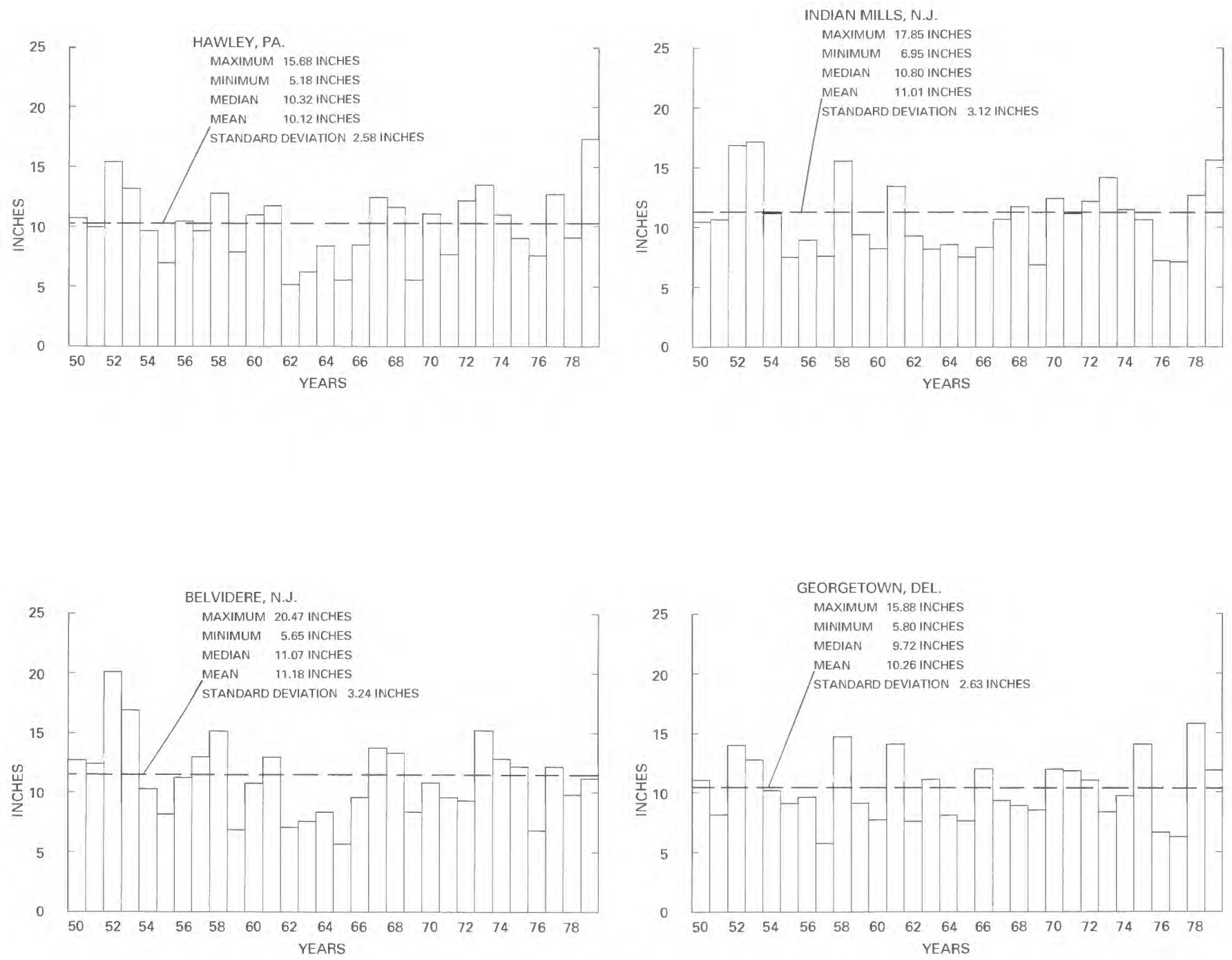

FIGURE 84.-Average spring (March-May) precipitation at four stations in the Delaware River basin, $1950-79$. 


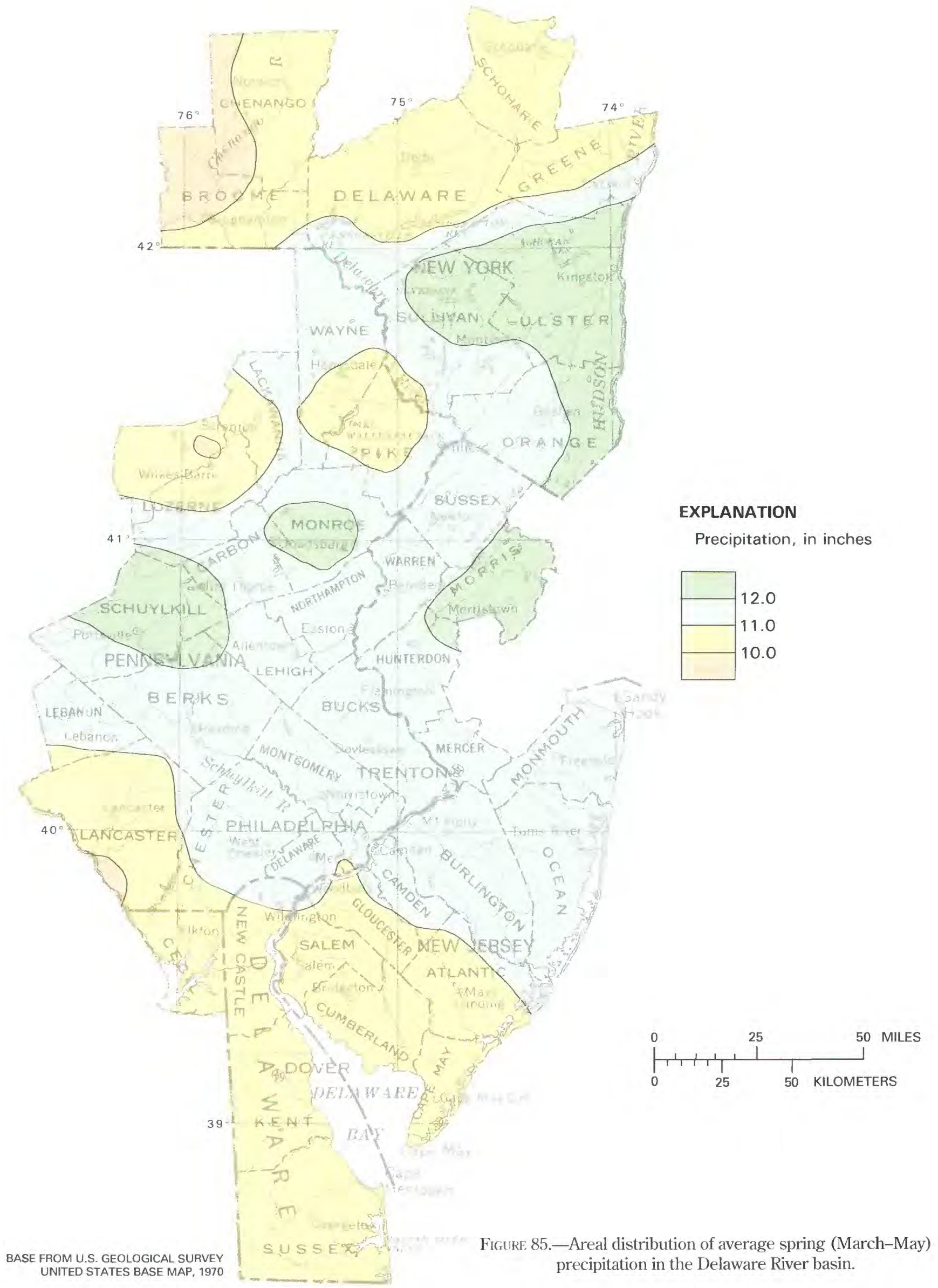




\section{AVERAGE SUMMER PRECIPITATION}

Average summer (June-August) precipitation (figs. 86 and 87 ) ranges from $10.51 \mathrm{in}$. to $13.92 \mathrm{in}$. Figure 86 shows the yearly values of summer precipitation for the four representative stations.
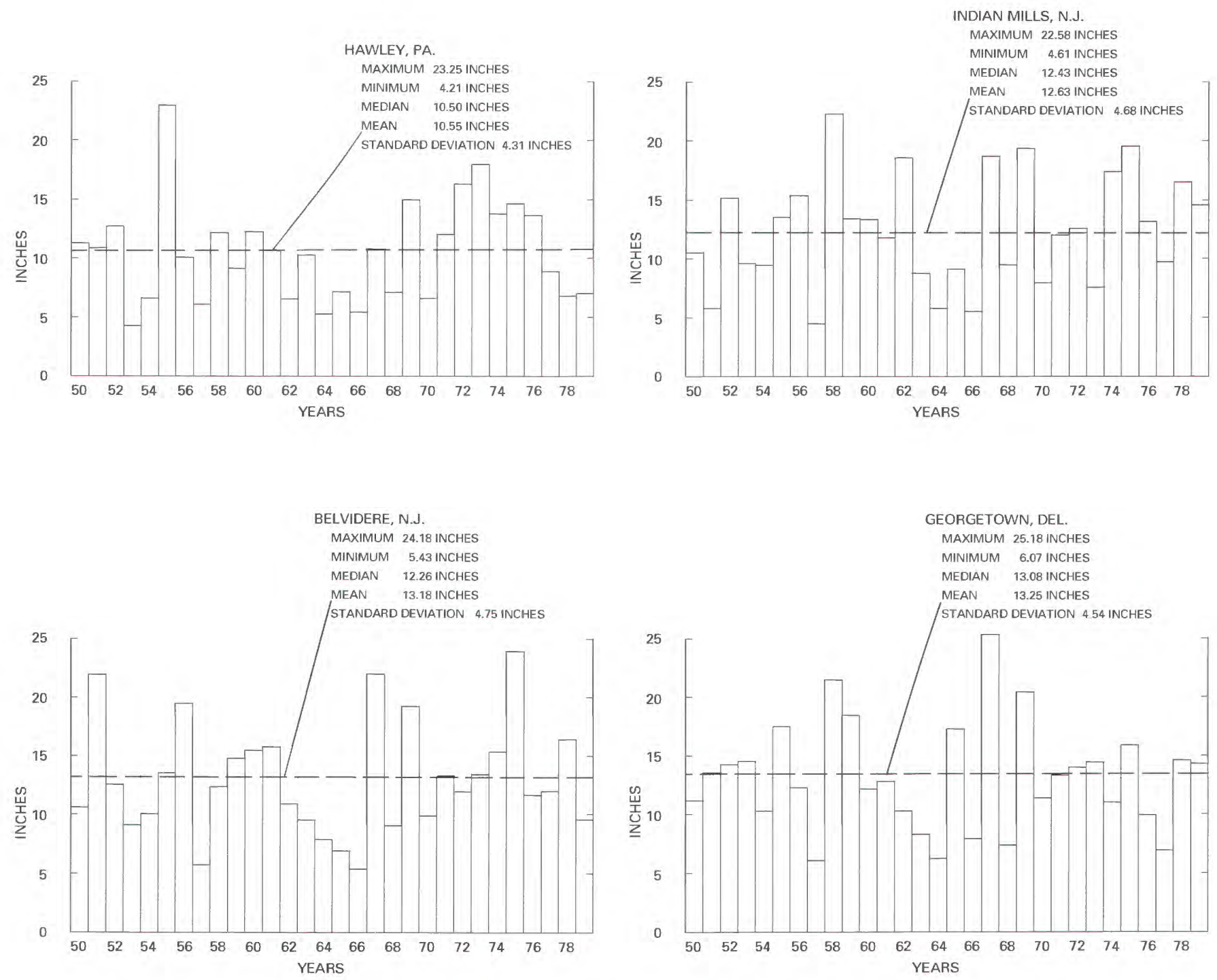

FIGURE 86.-Average summer (June-August) precipitation at four stations in the Delaware River basin, 1950-79. 


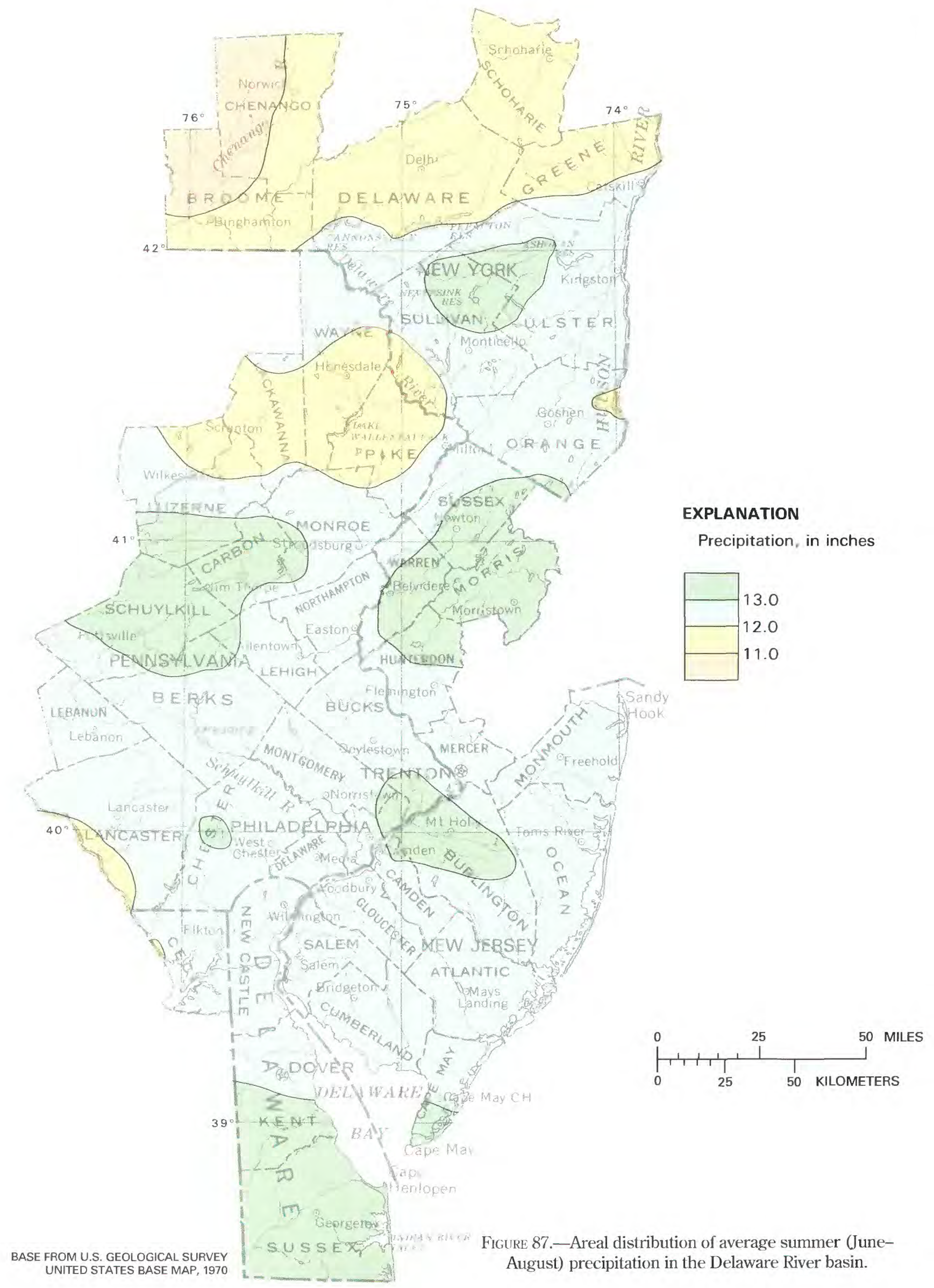


AVERAGE FALL PRECIPITATION

Average fall (September-November) precipitation (figs. 88 and 89 ) ranges from 9.37 in. to 14.42 in.

Figure 88 shows the time series plots of fall precipitation for the four representative stations along the northsouth transect in the basin.
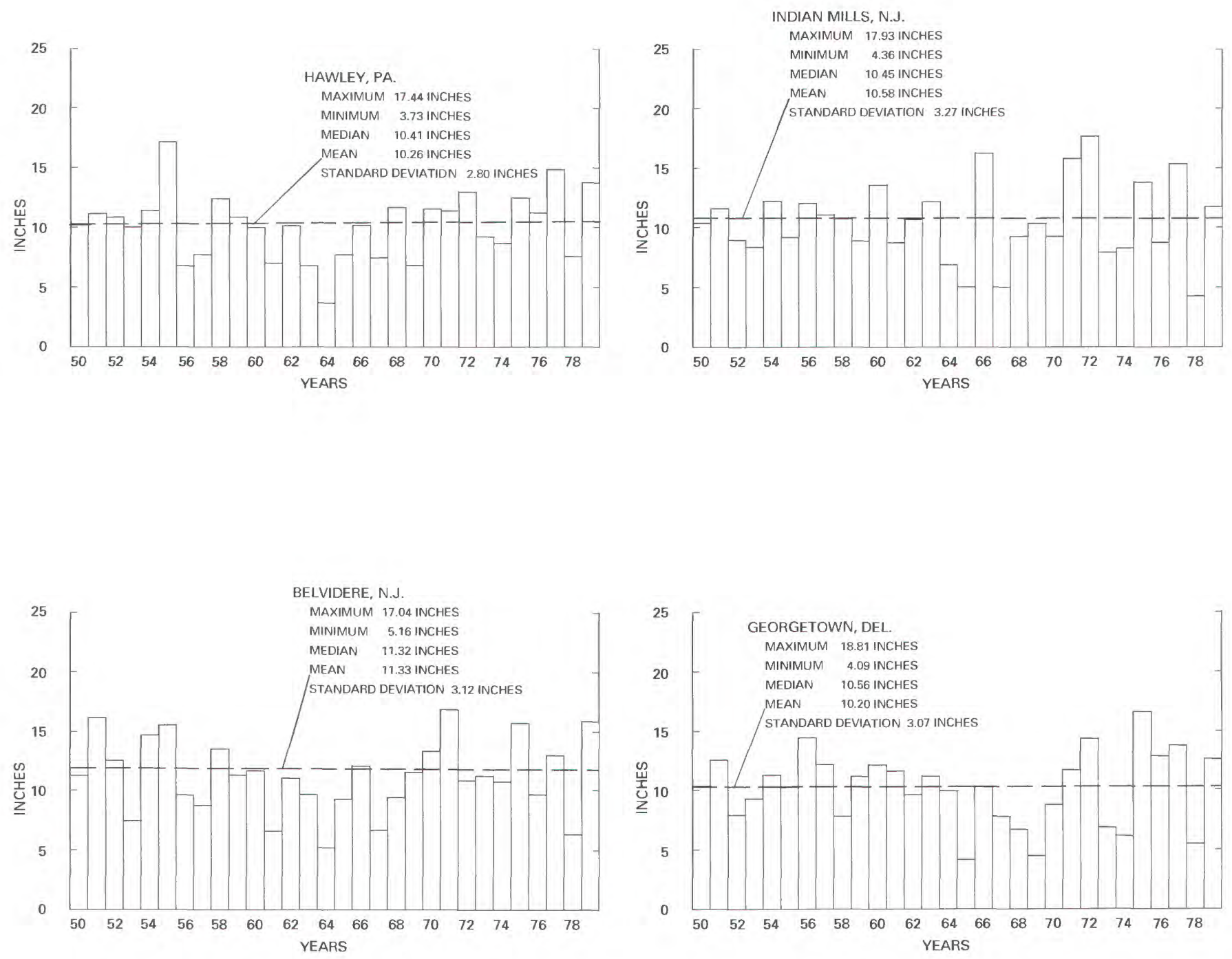

FigiriRE 88.-Average fall (September-November) precipitation at four stations in the Delaware River basin, 1950-79. 


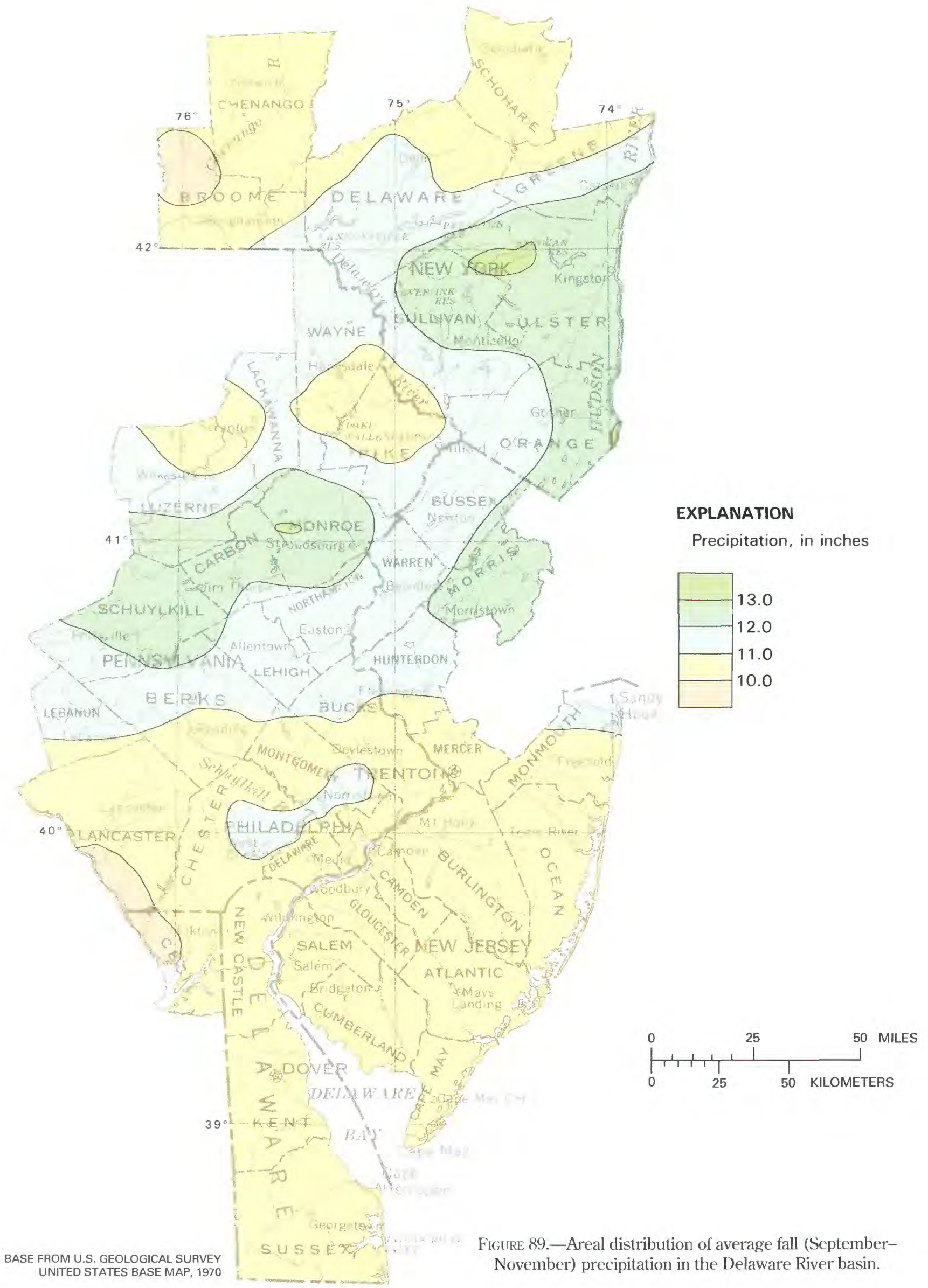


Average annual snowfall increases from south to north within the Delaware River basin (figs. 90 and 91). Average yearly snowfall at Wilmington, Del., is 21.8 in.; Allentown, Pa., receives 32.5 in.; and Binghamton, N.Y., averages $85.1 \mathrm{in}$. The graphs on figure 91 indicate the monthly distribution of snowfall at the three stations.
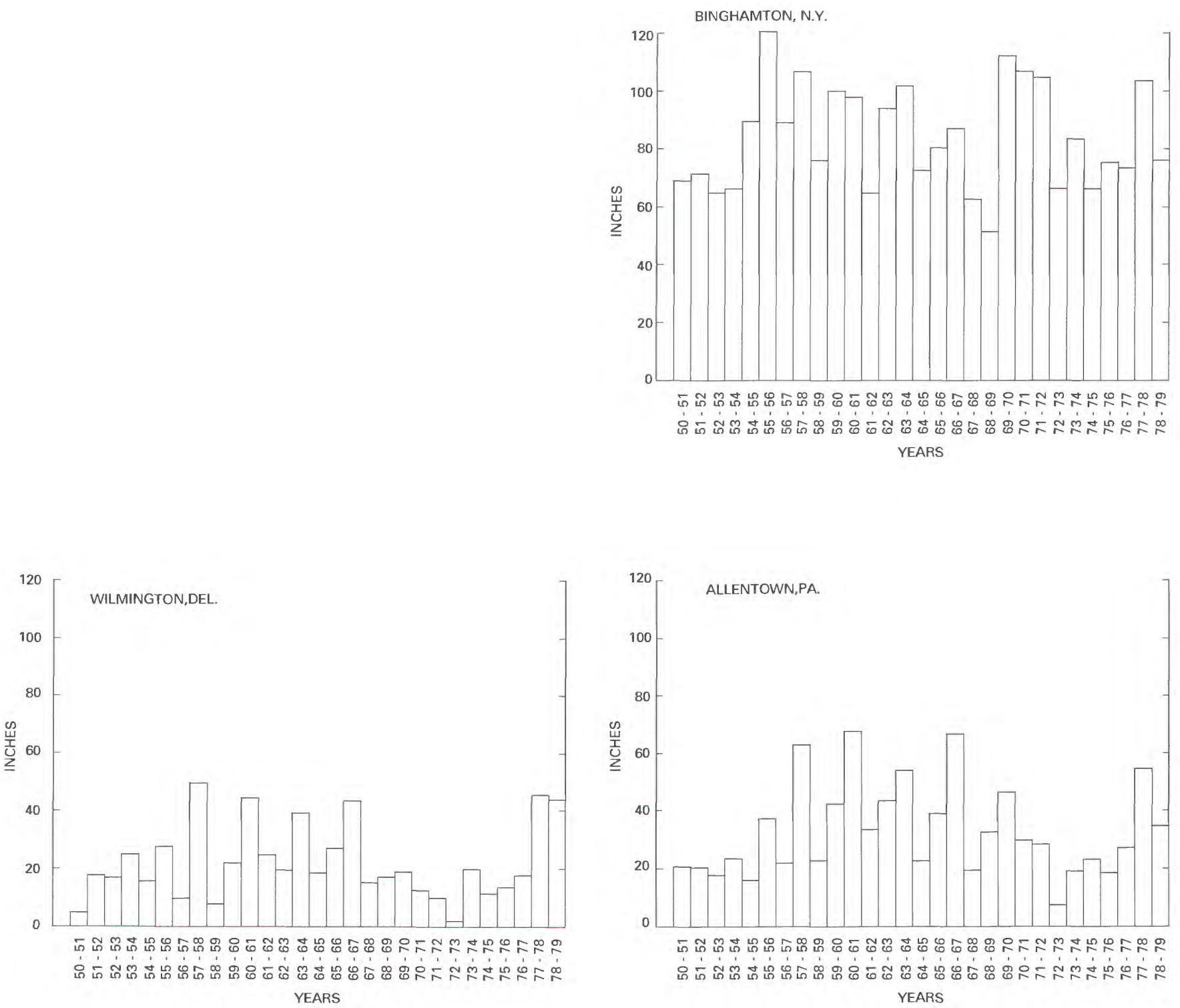

FIGURE 90.-Total annual snowfall at three stations in the Delaware River basin, 1950-79. 
Great year-to-year variability in snowfall exists as indicated by the time series plots (fig. 90). During the 1950-51 through 1978-79 seasons, annual totals at Wilmington, Del., range from 1.2 in. to 49.5 in.; Binghamton, N.Y., totals range from a minimum of 52.0 in. to 122.6 in.
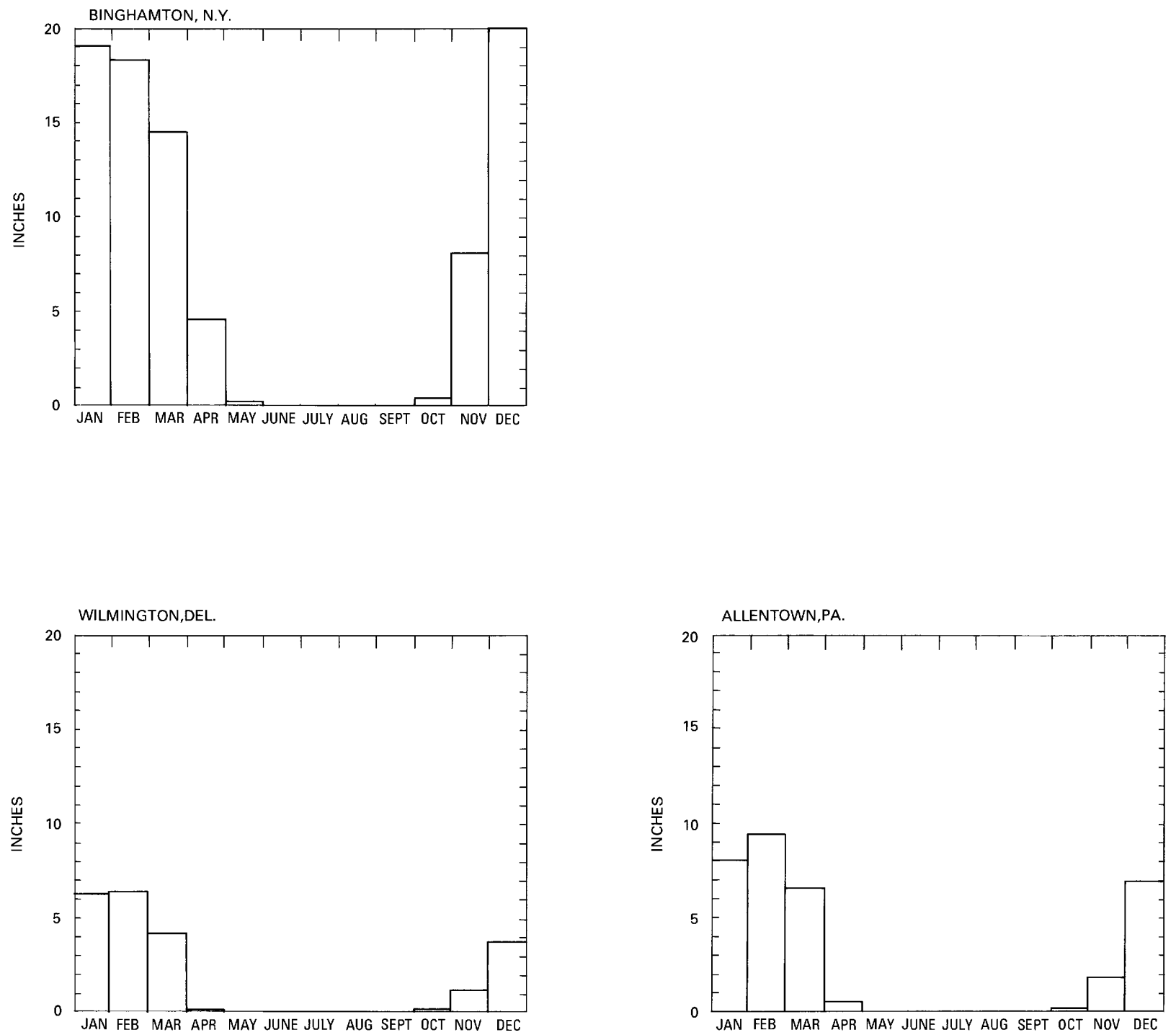

FigURE 91.-Average monthly snowfall at three stations in the Delaware River basin. 


\section{PRECIPITATION DAYS}

Figure 92 shows for each of three first-order climatological stations the average number of days per month on which measureable precipitation amounts were recorded. The total number of precipitation days increases from south to north. Wilmington, Del., averages 116 days per year; the Allentown, Pa., station averages 123 days per year; and Binghamton, N.Y., experiences 163 precipitation days per year. Of the three stations, Binghamton, N.Y., exhibits the greatest degree of seasonality in the monthly precipitation day totals, with the maximum number during the December through March period. Binghamton's high annual precipitation day and the seasonality of precipitation are due to the frequent occurrence of migratory lows affecting the northern part of the basin. This low pressure system activity peaks during the winter months as the polar front shifts to its southernmost location.
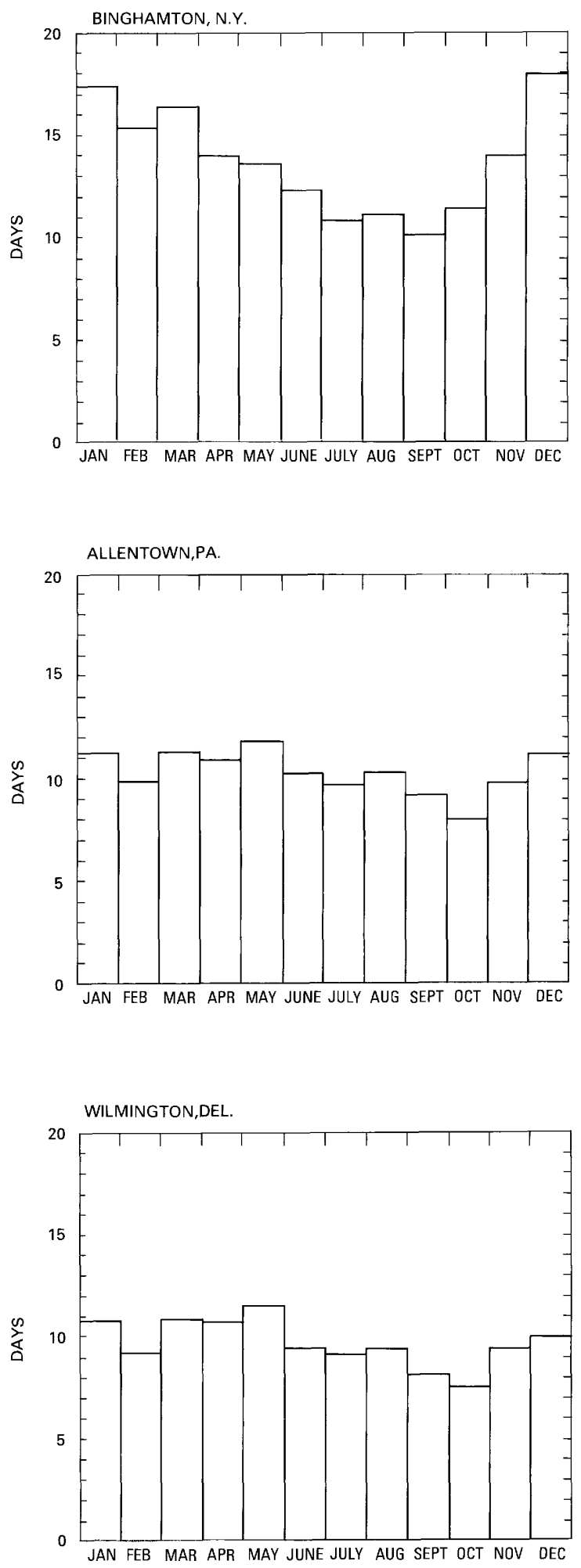

FIGURE 92.-Average monthly precipitation days at three stations in the Delaware River basin. 


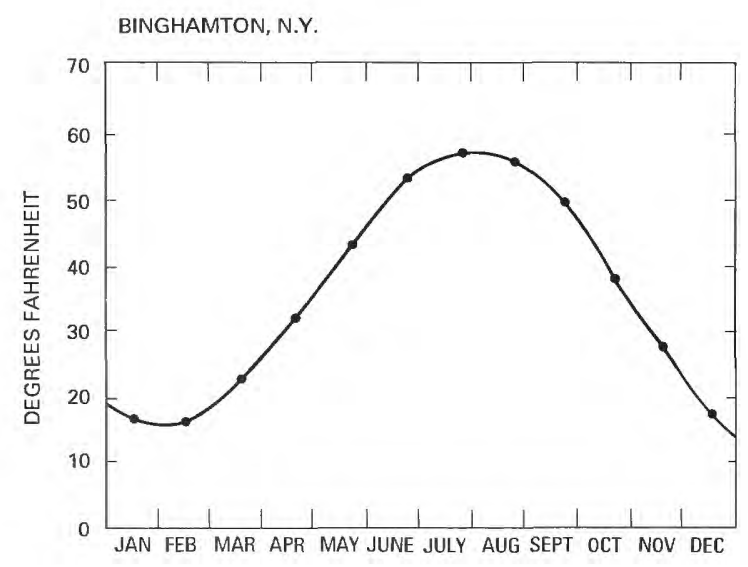

ALLENTOWN,PA.

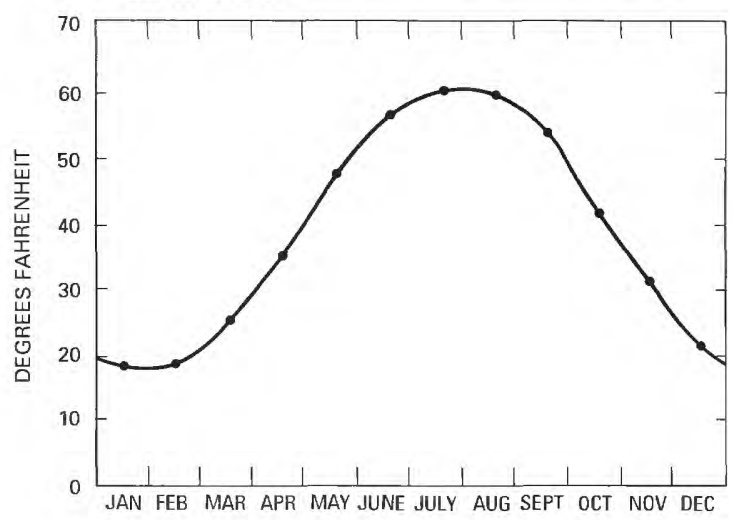

WILMINGTON,DEL.

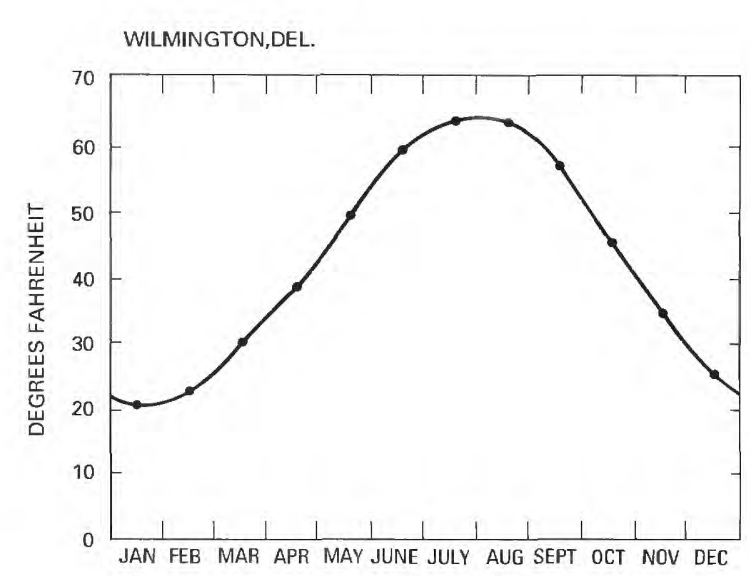

FIGURE 93.-Average monthly dew-point temperature at three stations in the Delaware River basin.
AVERAGE MONTHLY DEW-POINT TEMPERATURE

The dew point is calculated from psychrometric measurements made at first-order climatological stations. The graphs (fig. 93) show a slight decrease in average dew-point for each month along a south-to-north transect. This is a result of cooler average temperatures and the resulting diminished water vapor-holding capacity of the lower atmosphere along the transect. A seasonality in average dew-point temperature at each station is obvious. Again, this is a result of the annual course of air temperature and accompanying changes in the ability of the atmosphere to hold water vapor. 


\section{GLOUD COVER}

Several measures of cloud cover are used in the climatic summaries published by the National Oceanic and Atmospheric Administration. The measurements plotted here involve classifying individual days into three categories based on daytime cloudiness. A day having 8 to 10 tenths cloud cover is considered "cloudy"; one having 4 to 7 tenths cloud cover is considered to be "partly cloudy"; and a day having 0 to 3 tenths cloud cover is classified "clear." Figure 94 shows the average percentage of days falling into these three categories by month for the 30-year period of study.

The total number of cloudy days per year increases from south to north, but the total clear days per year decreases. A definite seasonal component exists in these frequencies; at all stations there are more cloudy days in winter than in summer. This seasonality is most pronounced at Binghamton, N.Y.

The time series plots (fig. 95) depict the summer (June-August) and winter (December-February) percentages of clear days for the 30 years of records used in this study.
THUNDERSTORM DAYS

The graphs (fig. 96) indicate the average number of days per month during which thunderstorms occur. Thunderstorms are most common in the summer months when relatively intense surface heating combines with moist, unstable air masses to produce convectional storms.
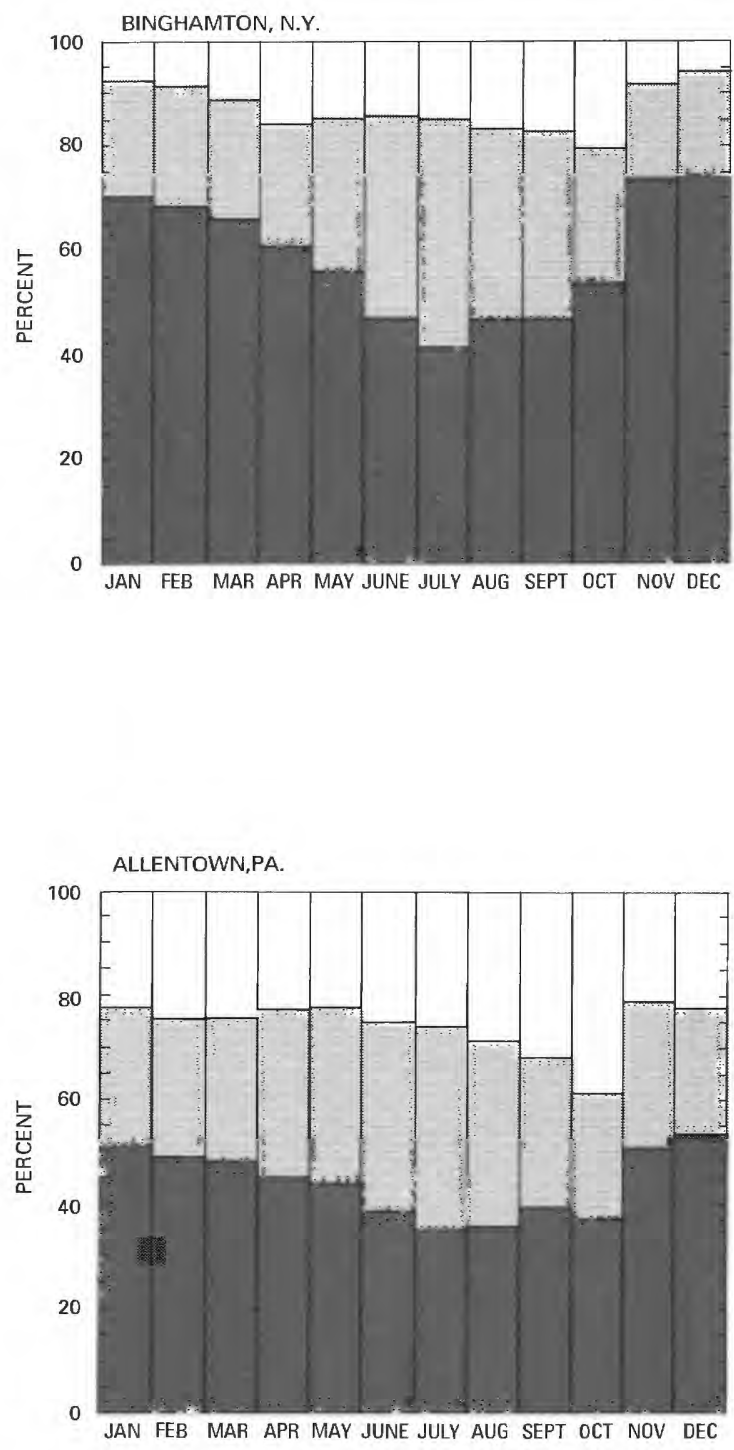

\section{EXPLANATION}

Clear (0-3 tenths cloud cover)

Partly cloudy (4-7 tenths cloud cover)

Cloudy (8-10 tenths cloud cover)

FiguRE 94.-Monthly percentage of clear, partly cloudy, and cloudy days for three stations in the Delaware River basin. 
PERCENTAGE OF CLEAR DAYS ( 0-3 TENTHS CLOUD COVER) SUMMER
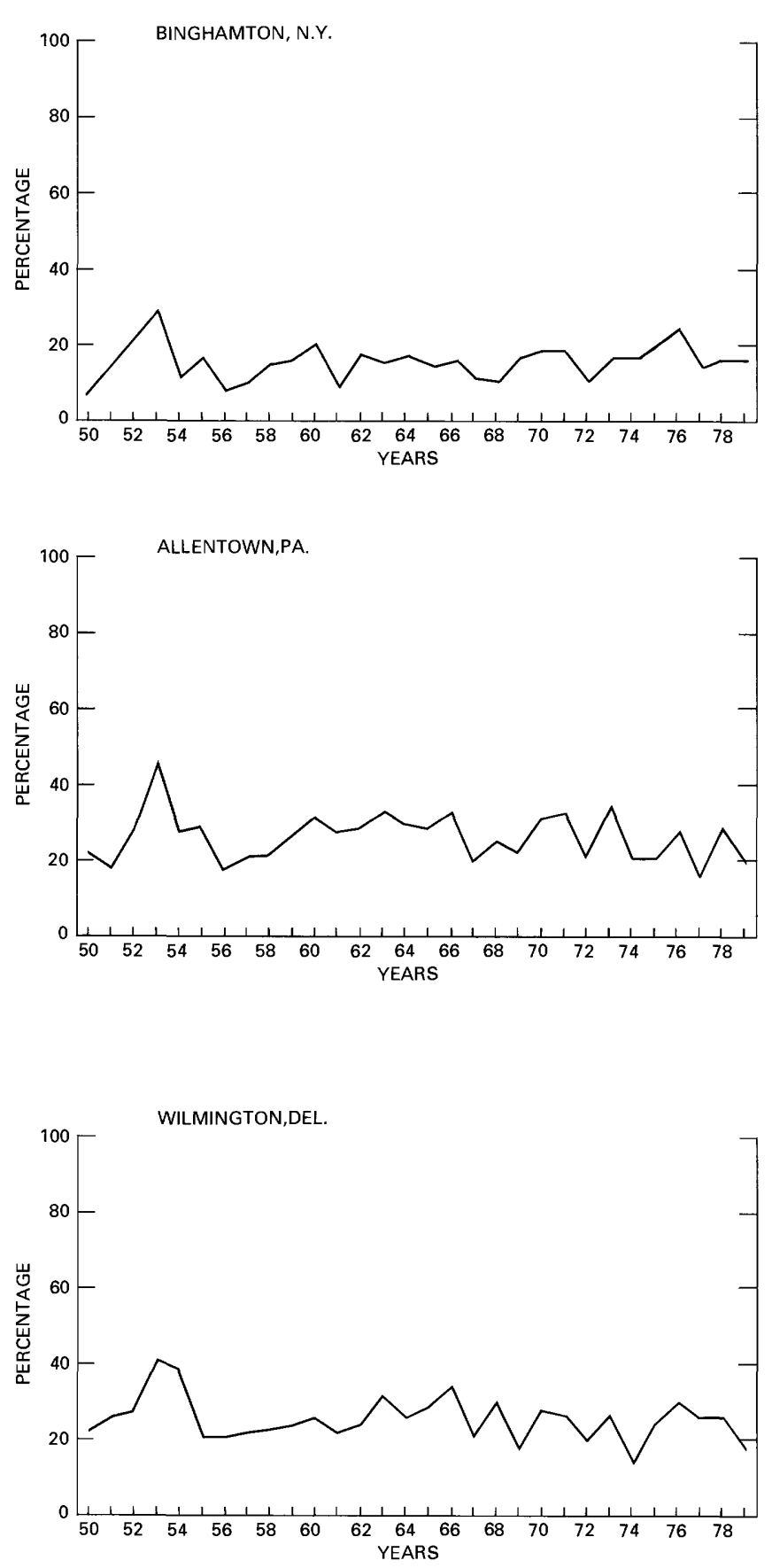

PERCENTAGE CLEAR DAYS ( 0-3 IENTHS CLOUD COVER) WINTER
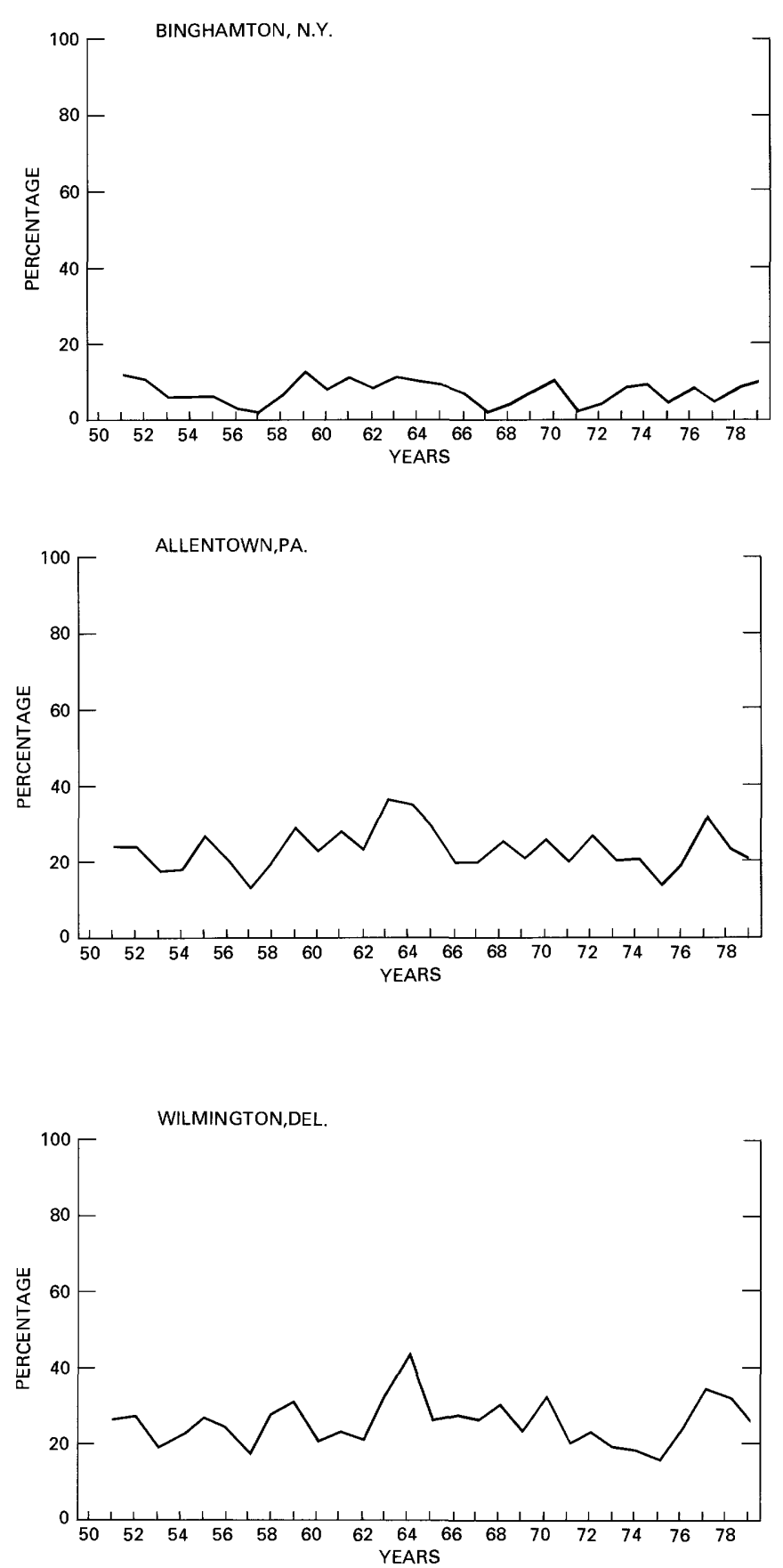

FIGURE 95-Annual percentage of clear summer and winter days at three stations in the Delaware River basin, 1950-79. 

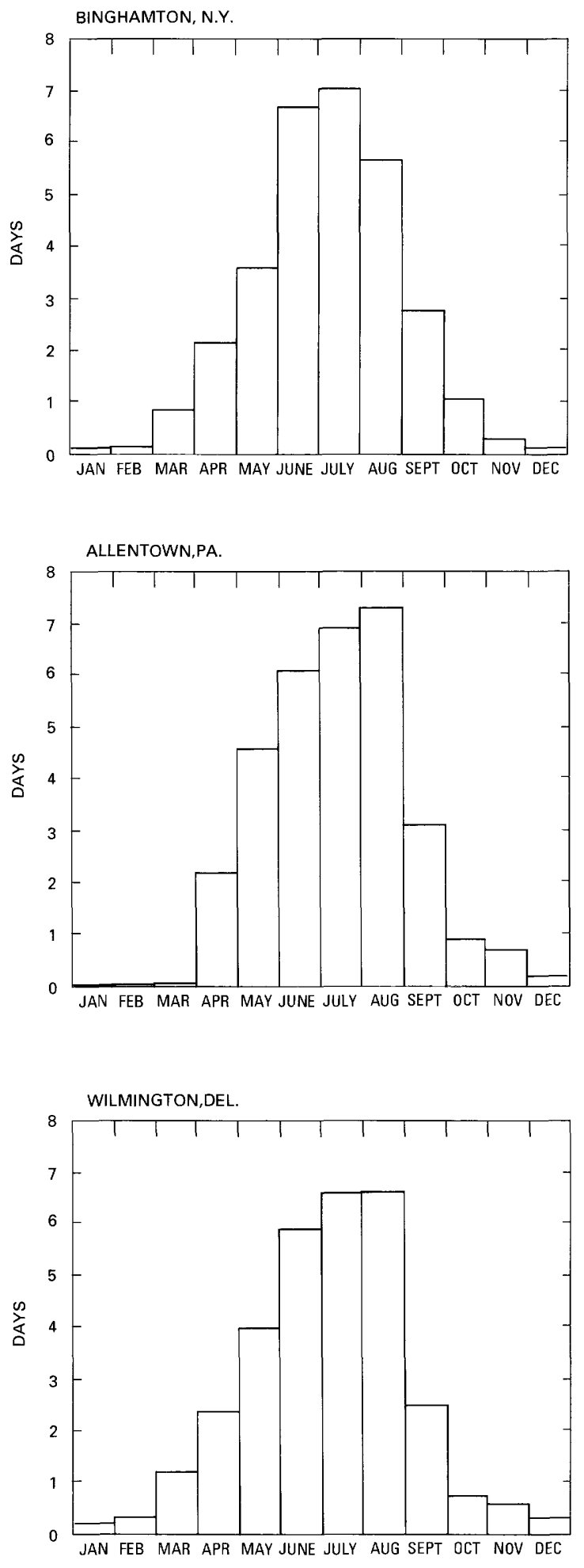

FIGURE 96.-Average days per month of thunderstorm occurrence at three stations in the Delaware River basin.

\section{CLIMATIC WATER BUDGET}

The preceding discussions have treated climatic variables individually, without consideration of the covariability of these terms in any fashion. One method of climatological analysis that does incorporate several climatic variables involves the calculation of water budgets.

Water-budget studies may be done at spatial scales ranging from local to global and at temporal scales ranging from daily to annual. The analyses presented here were performed on a monthly basis for individual climatic stations; the explanation that follows focuses on these scales.

In water-budget analysis, precipitation is treated as input or "supply" to the environmental system. The primary "demand" is evaporation and transpiration, termed evapotranspiration. Potential evapotranspiration is defined as the amount of evapotranspiration occurring over a continuous vegetated surface with an abundant soil-moisture supply. It is a function of the amount of energy available to accomplish evapotranspiration.

In monthly water-budget calculations, when precipitation exceeds potential evapotranspiration, the actual evapotranspiration for that month is considered equal to the potential amount. Excess water may be stored as soil moisture until the soil-moisture storage reaches an upper limit, known as the field capacity. Any additional precipitation excess is termed water surplus and may contribute to runoff or ground-water storage.

During a month when potential evapotranspiration exceeds precipitation, all precipitation goes toward actual evapotranspiration. Some water stored as soil moisture is also extracted to satisfy the climatic water demand. The contributions of precipitation and soil moisture to the actual evapotranspiration usually do not meet the entire water demand represented by the potential evapotranspiration. The difference between the actual evapotranspiration and the potential evapotranspiration is termed the water deficit for that month.

These basic water-budget calculations have been adapted for use in a variety of applications. Chief among these are agricultural studies, for which water budgets have been used for irrigation-scheduling and crop-yield predictions (fig. 97). Many hydrologic studies have incorporated water-budget calculations to forecast runoff and ground-water levels.

Calculation of Water-Budget Terms.-The general waterbudget approach described above and the procedures used in the calculation of the water-budget terms were developed by Thornthwaite (1948). More recently, Mather (1978) has elaborated on these procedures and has described many applications of water budgeting to problems in environmental analysis. 
Actual water-budget calculations require (1) long-term average monthly air-temperature data, (2) station latitude, (3) monthly temperature and precipitation data for the period of analysis, and (4) maximum possible soil moisture storage in the plant root zone. First, the annual heat index $I$ is calculated by

$$
I=\sum_{i=1}^{12}\left(\begin{array}{c}
t_{i} \\
5
\end{array}\right)^{1514}
$$

where $t_{i}=$ the long-term average temperature for the $i^{\text {th }}$ month of the year. The annual heat index, in turn, is used to evaluate the parameter $a$ :

$$
\begin{aligned}
a= & 6.75 \times 10^{-7} I^{3}-7.71 \times 10^{-5} I^{2} \\
& +1.792 \times 10^{-2} I+0.49239 .
\end{aligned}
$$

The heat index and the parameter $a$ were used by Thornthwaite to relate empirically collected evaporation data to air temperature. The monthly potential evapotranspiration $(e)$ in centimeters is calculated for a 12-hour day, 30-day month by

$$
e=1.6\left(\frac{10 T}{I}\right)^{a},
$$

where $T$ is the monthly average temperature $\left({ }^{\circ} \mathrm{C}\right)$. This unadjusted value is then corrected by allowing for the appropriate day length and number of days in a month. This final value is the monthly potential evapotranspiration.

Precipitation data are used directly in the waterbudget calculations and are compared to the calculated potential evapotranspiration data on a month-to-month basis. The final necessary piece of information for completion of the accounting procedure is related to the water-storage capability of the soil. This varies according to the soil texture; the finer textured soils have greater moisture-storage capacity than coarse textured soils. The depth of the rooting zone of the plant cover also affects the total amount of water available for transpiration.

Water-budget calculations have been made for all stations in the Delaware River basin that collect temperature and precipitation data. The purpose of this analysis is to provide a basis for comparison among these stations when climatic parameters derived from both temperature and precipitation are considered. All budgets have been calculated uniformly, assuming a maximum possible soil-moisture storage of $4.00 \mathrm{in}$. When soil-moisture stores are used to satisfy the potential evapotranspiration demand, it is assumed that the rate of water loss by the soil varies directly with the soil moisture content. A soil at field capacity readily releases water to transpiration; a soil nearly depleted of moisture does not readily release water. A final assumption relates to the treatment of precipitation that falls as snow. In the calculations that follow, all precipitation occurring in a month with average temperature of $32^{\circ} \mathrm{F}$ or below (with zero potential evapotranspiration) is included as surplus for that month.

\section{WATER BUDGET FOR THE DELAWARE RIVER BASIN}

\section{POTENTIAL EVAPOTRANSPIRATION}

The maps that follow (figs. 98-107) depict average annual potential evapotranspiration and individual monthly average values for all months having potential evapotranspiration values significantly different from zero. The annual potential evapotranspiration values throughout the basin range from approximately $23 \mathrm{in}$. to $30 \mathrm{in}$. (fig. 108). The values are clearly a function of temperature, albeit a nonlinear relation.

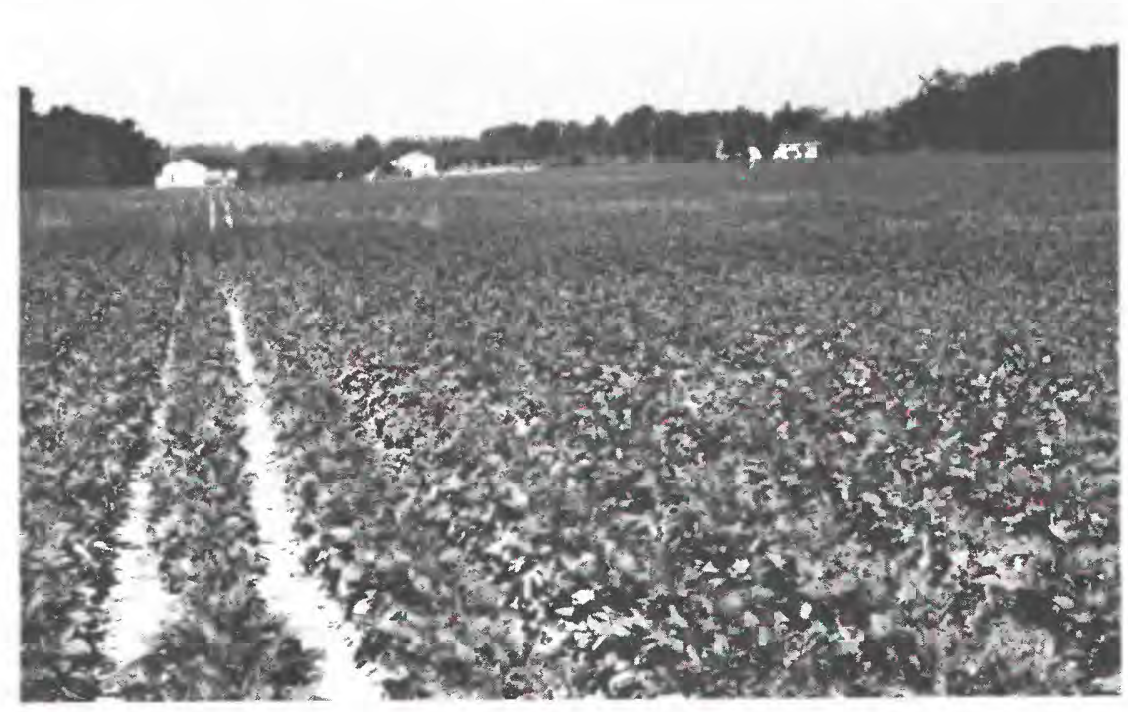

FIGURE 97.--Truck gardening in the southern New Jersey coastal plain. 


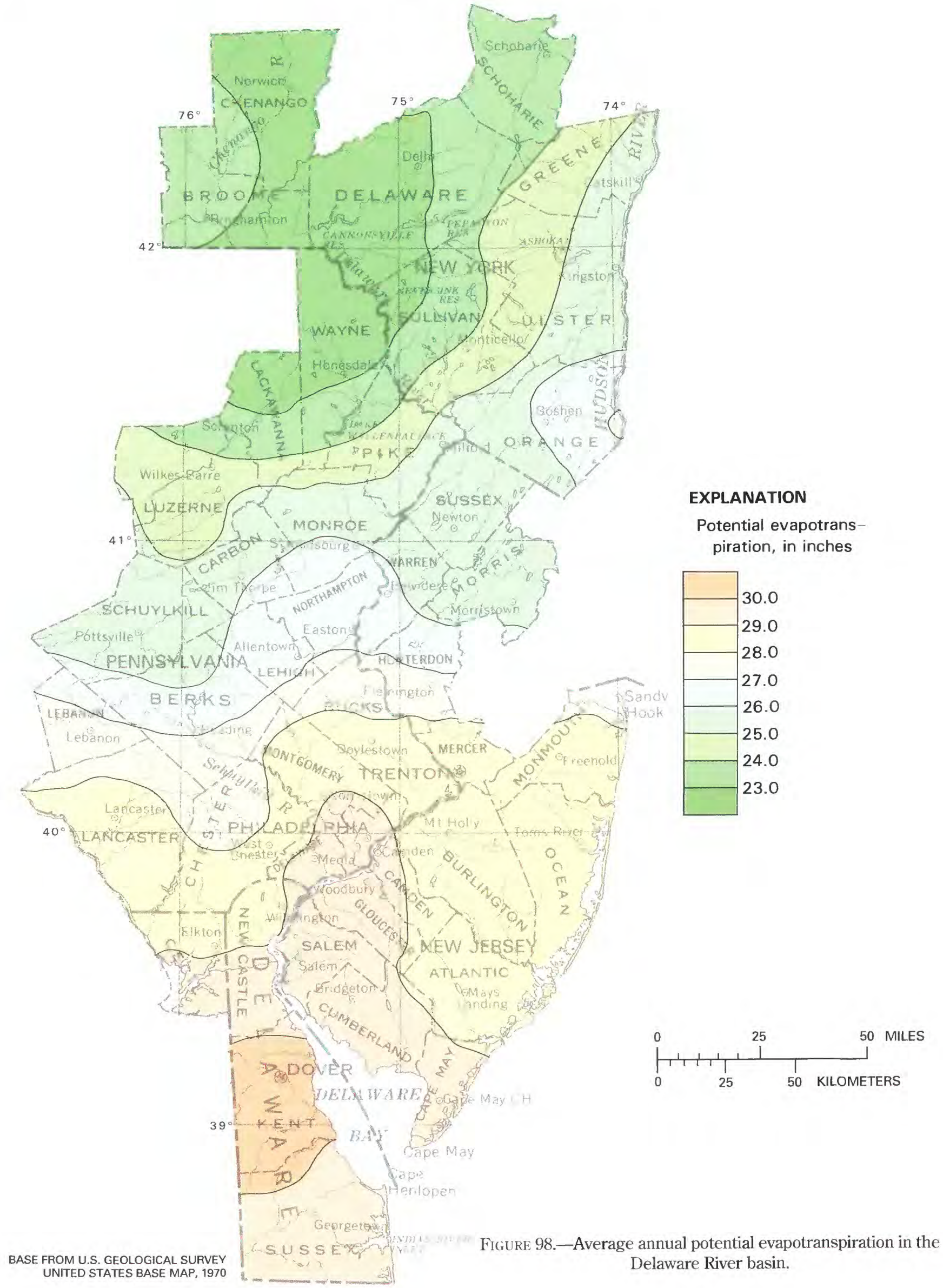




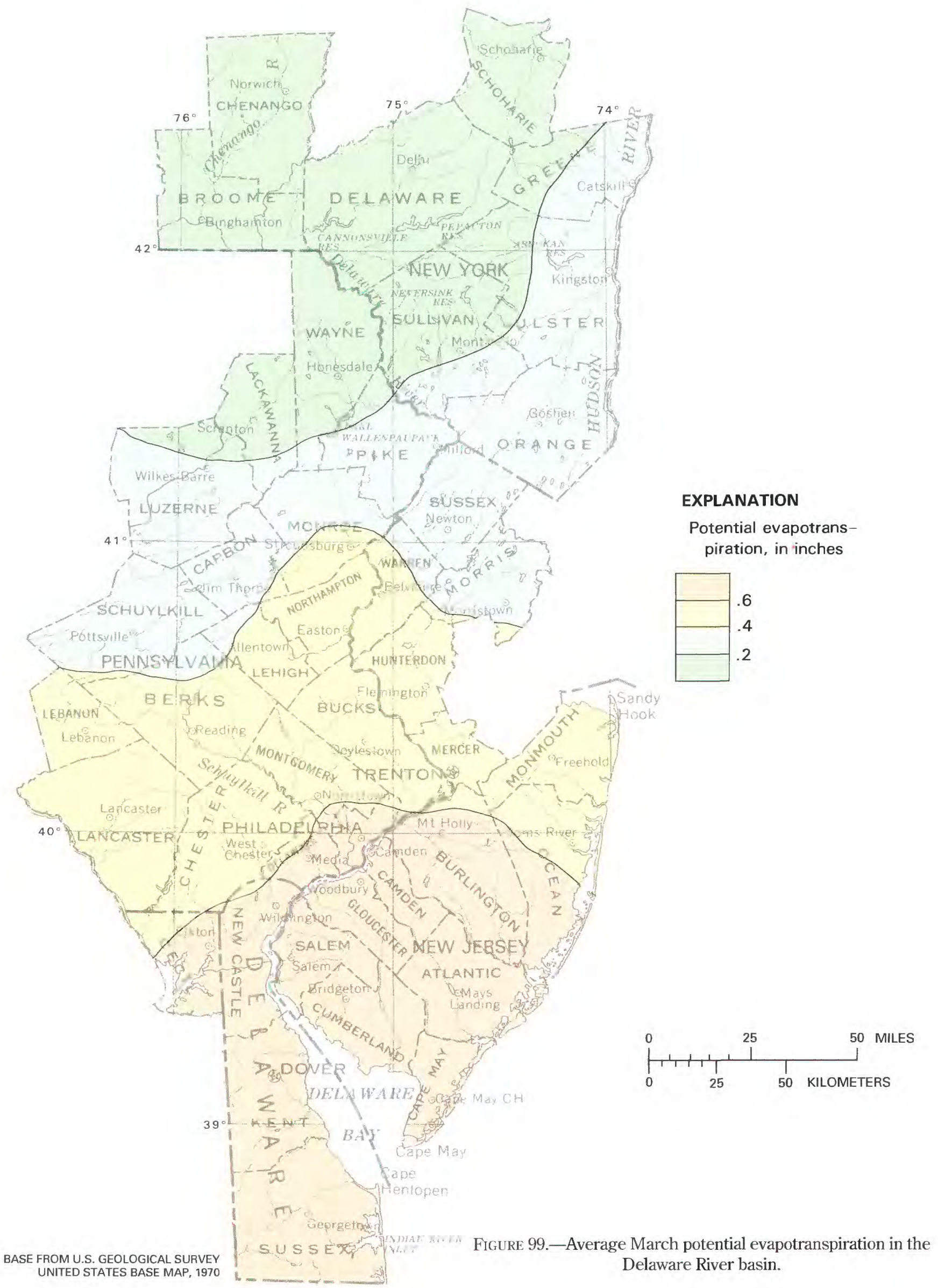




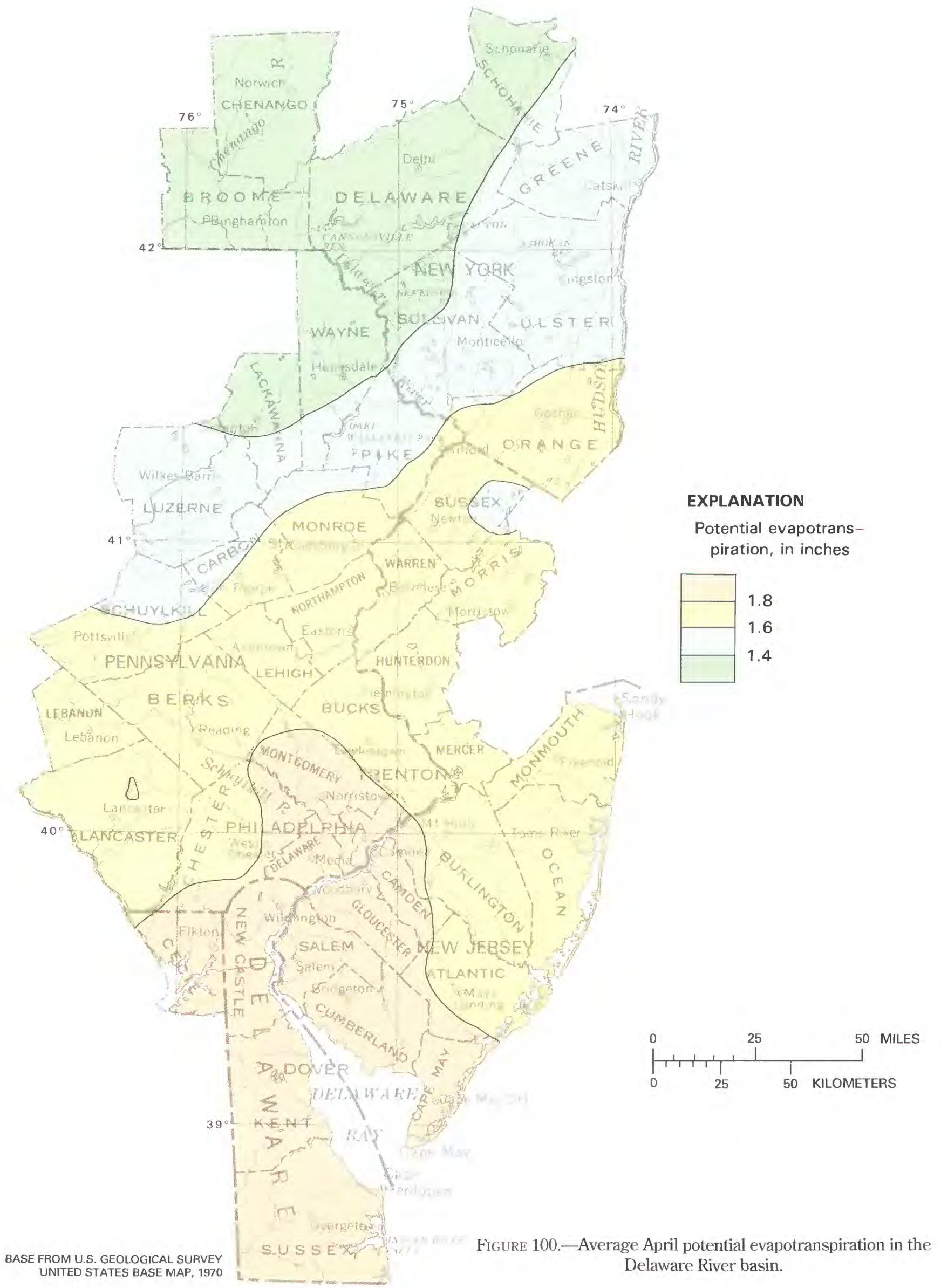




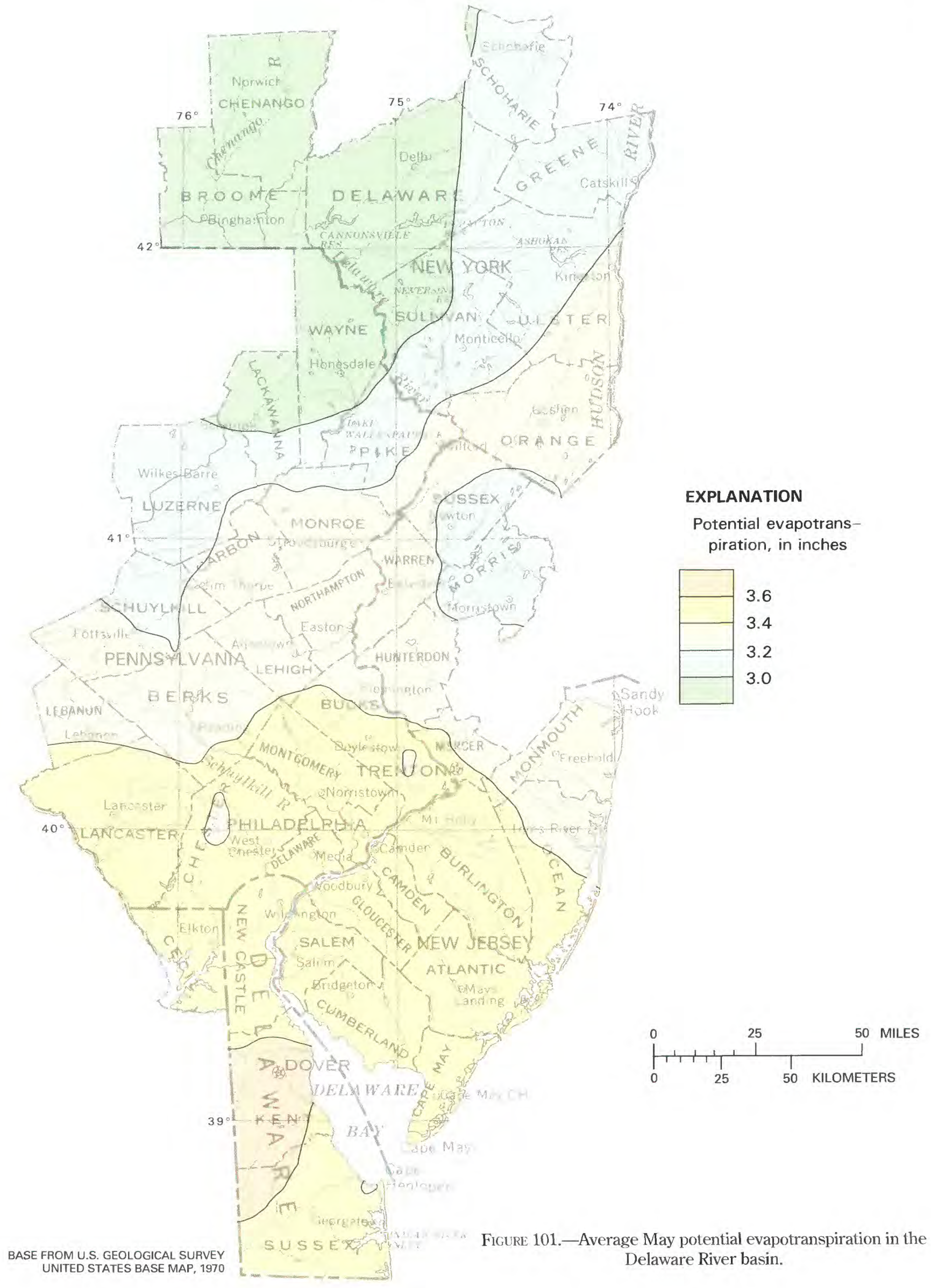




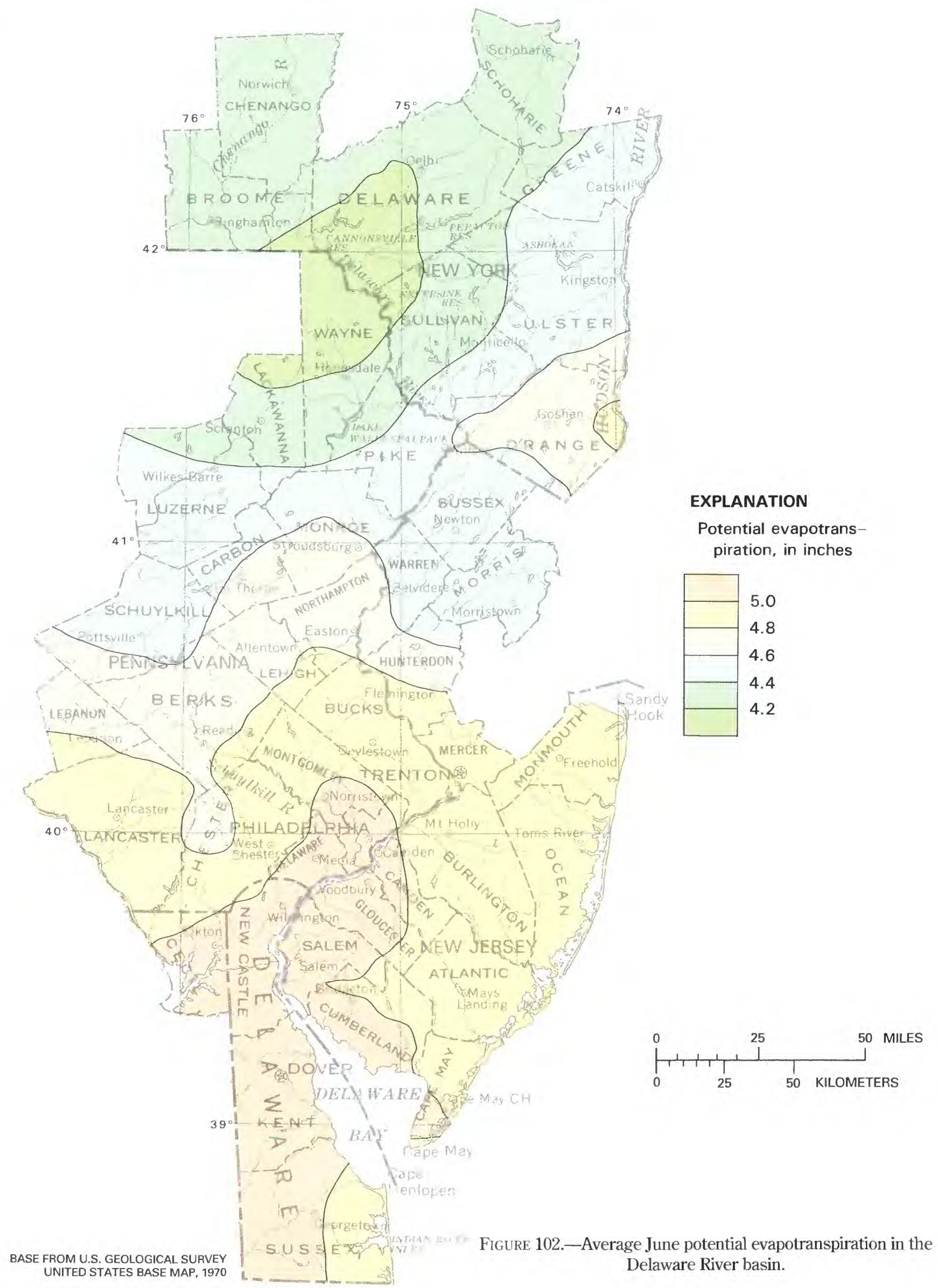




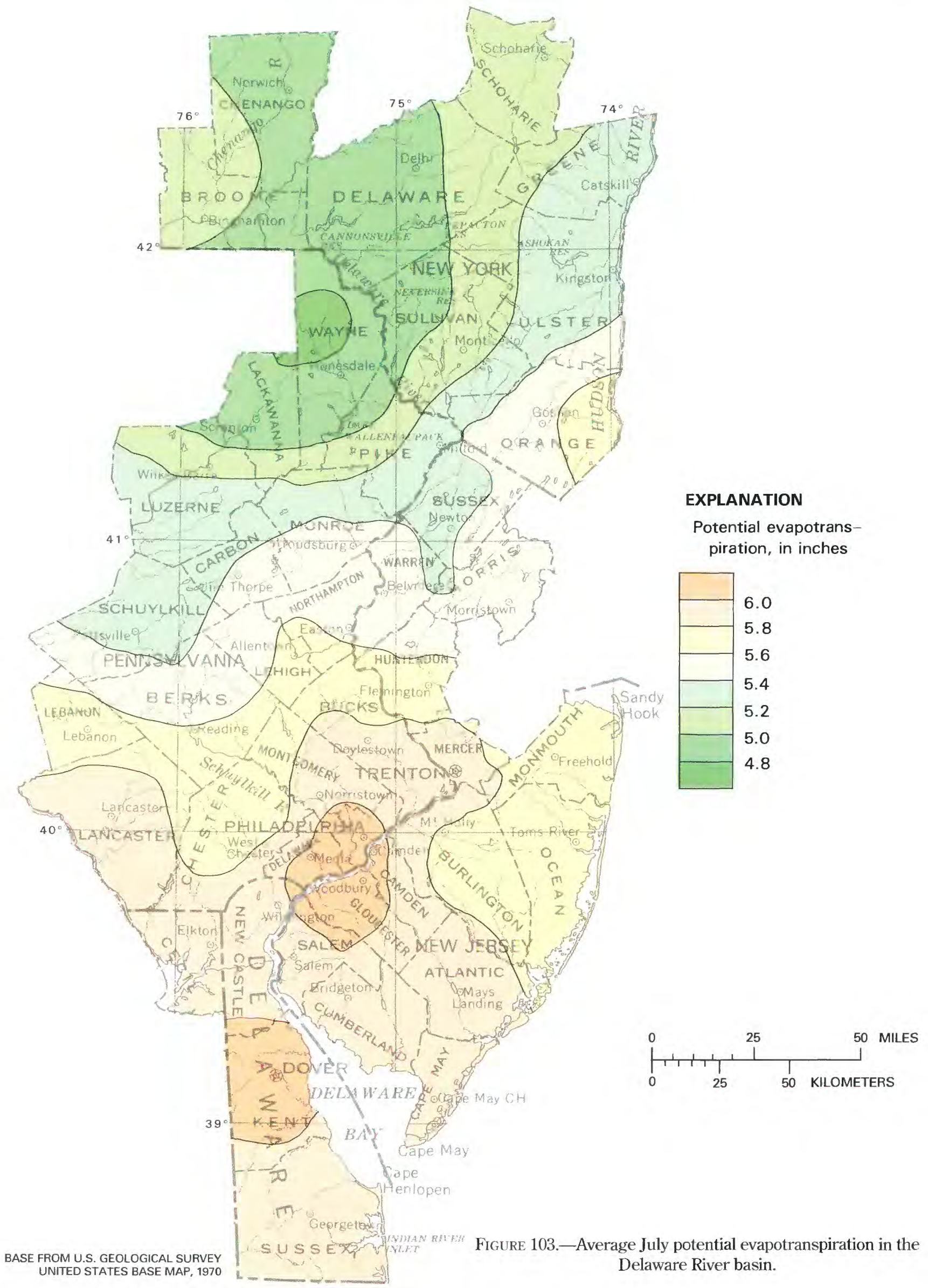




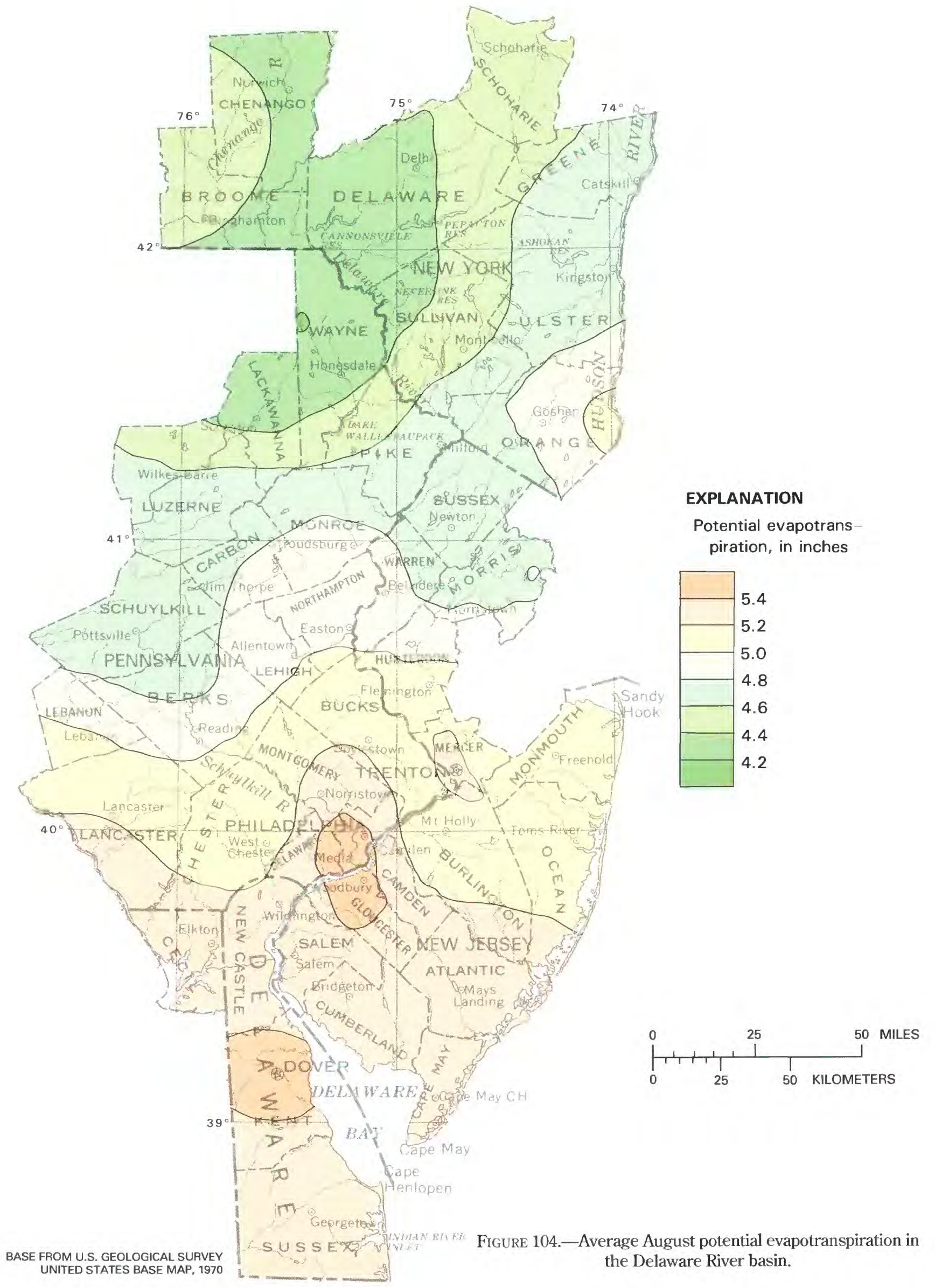




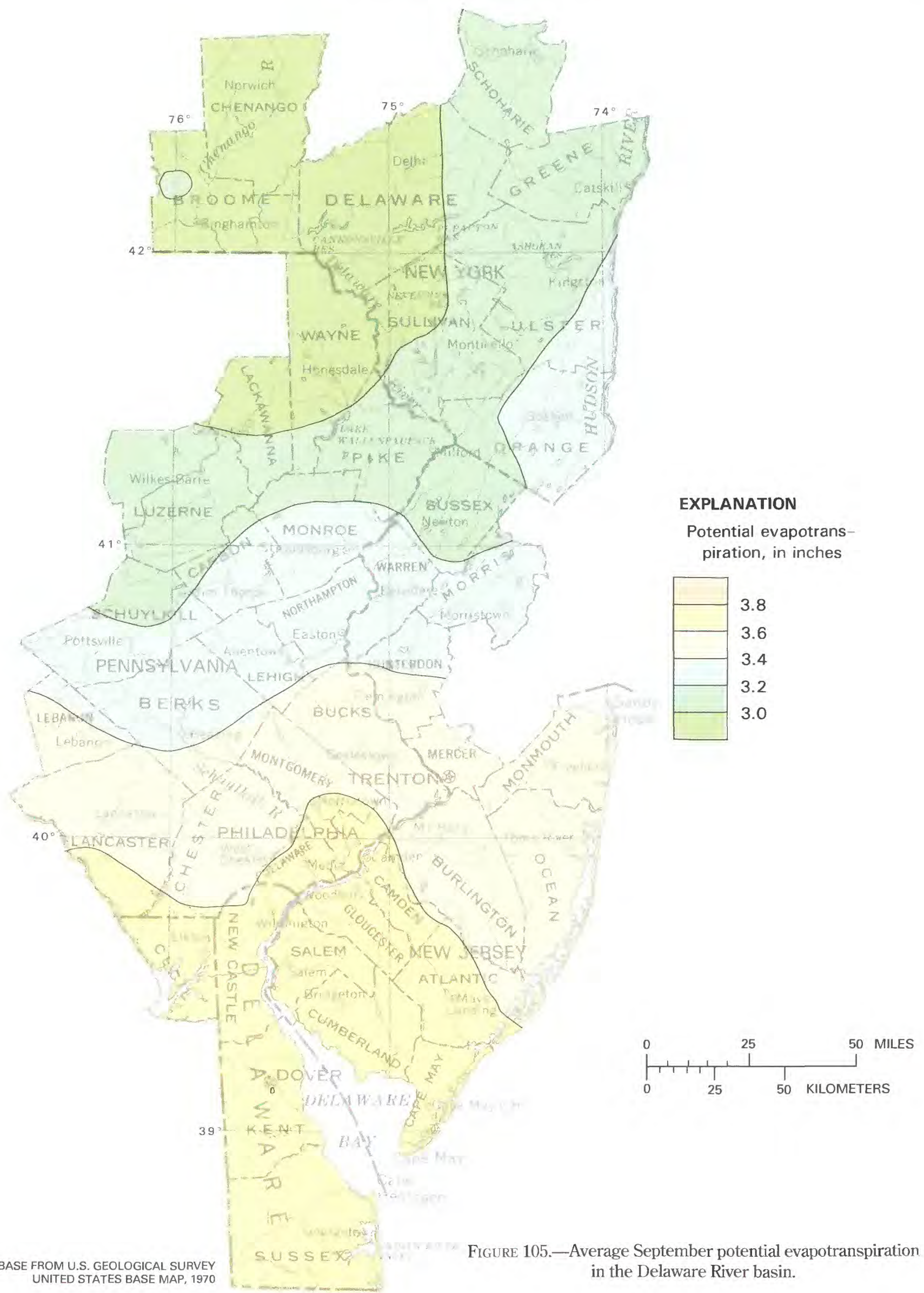




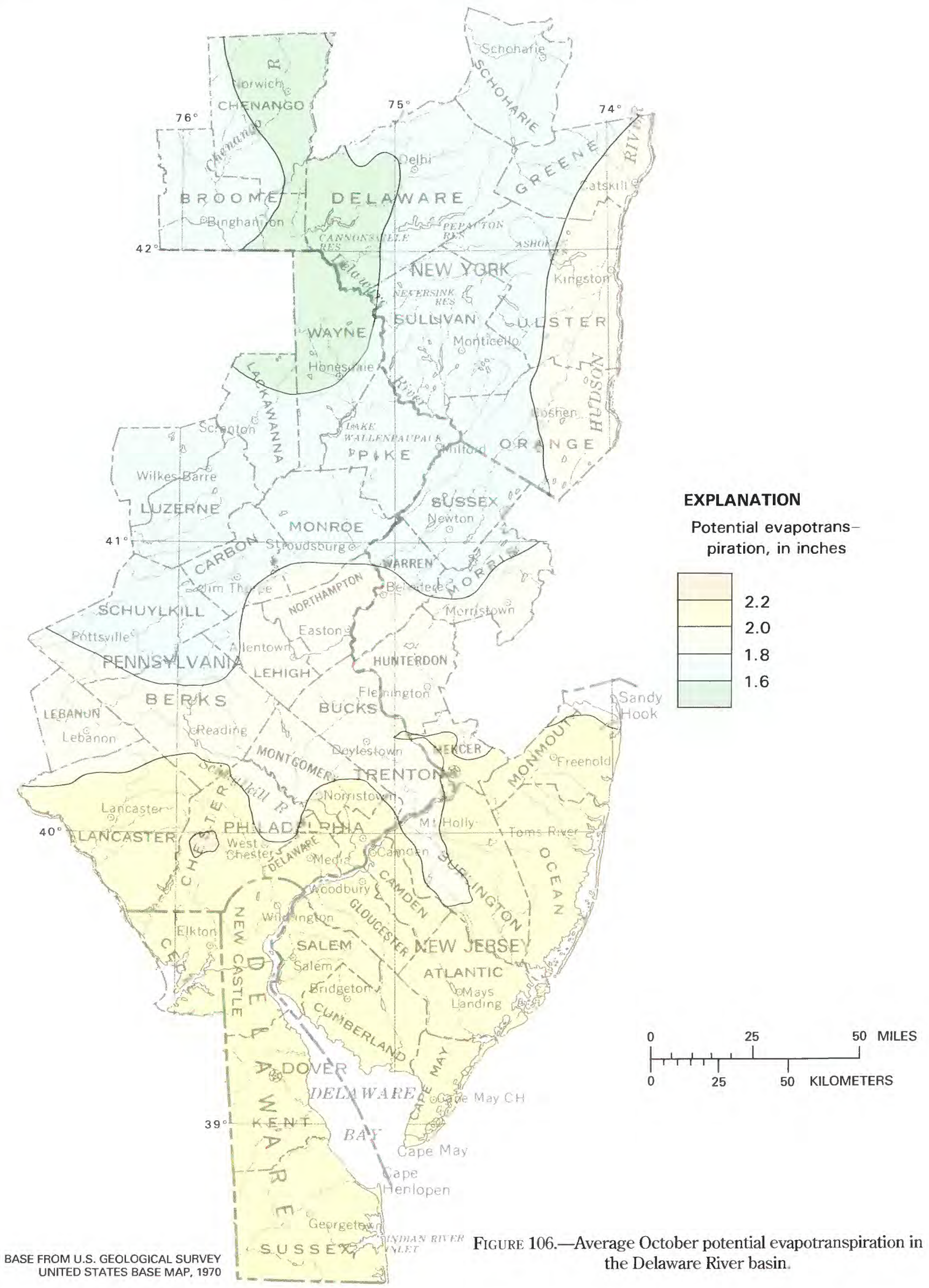




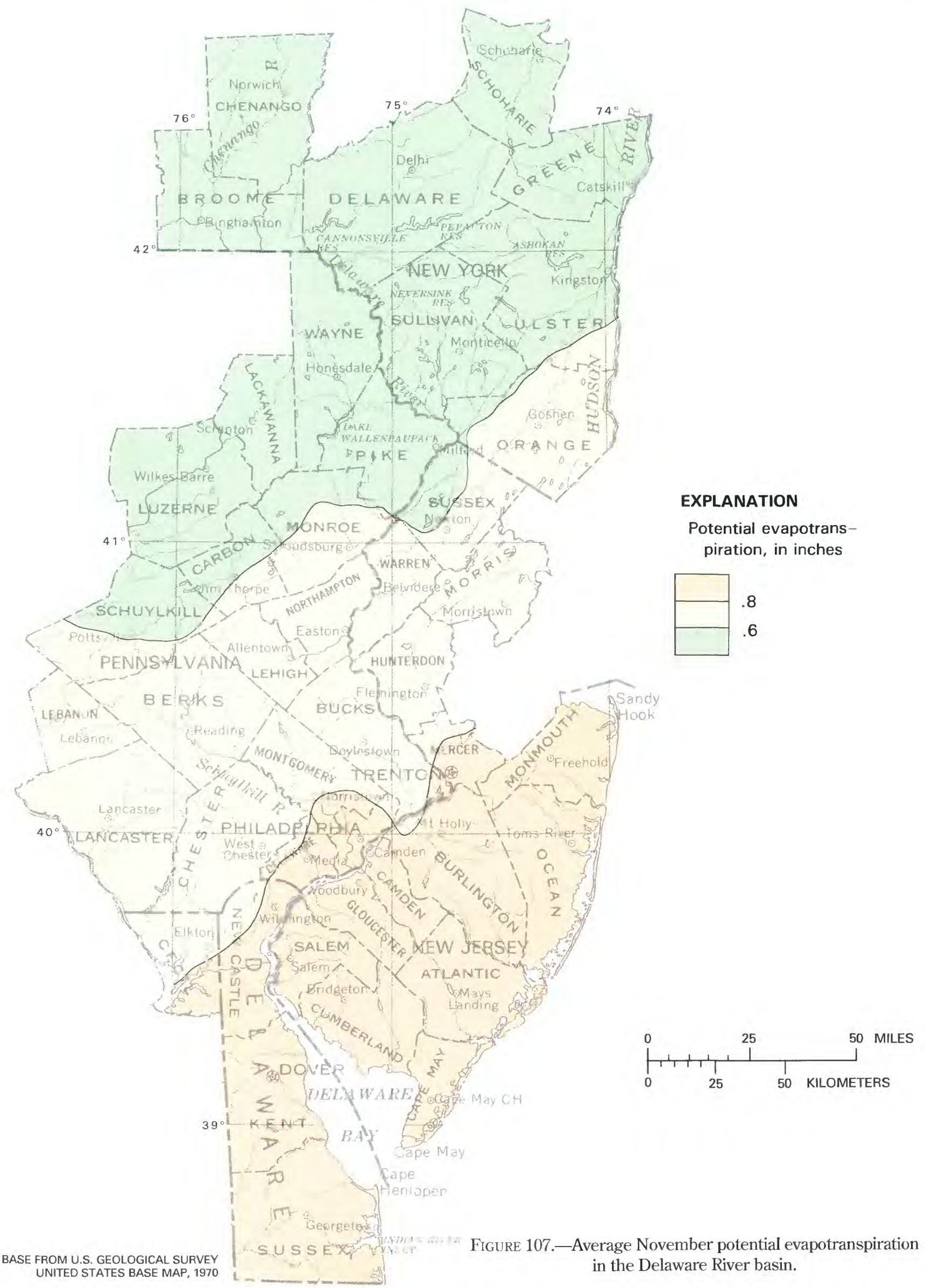




\section{WATER SURPLUS}

The largest water surpluses of over 26 in. are calculated for the Catskills stations, where temperatures (and potential evapotranspiration) are relatively low for the basin and where precipitation totals are relatively high. The lowest values, less than 16 in., occur in the southern part of the basin. The extreme northwestern area of the basin is associated with relatively low water surpluses (18 to 22 in.) due to relatively low precipitation receipt.

The water surpluses occur seasonally; the winter months are the times of high surplus (figs. 109-117). Figures 111, 113, 115, and 117 depict the average water surplus over the basin for winter, spring, summer, and fall, respectively. Time series plots (figs. 110, 112, 114, and 116) for four stations along a north-south transect within the basin accompany the maps. Water surpluses dominate the winter and spring seasons. Average surplus values for summer are the result of a few individual years of water surplus being averaged with many years of no summer water surplus. In the fall, situations of water surplus are more common than in summer but some years of zero surplus have occurred.

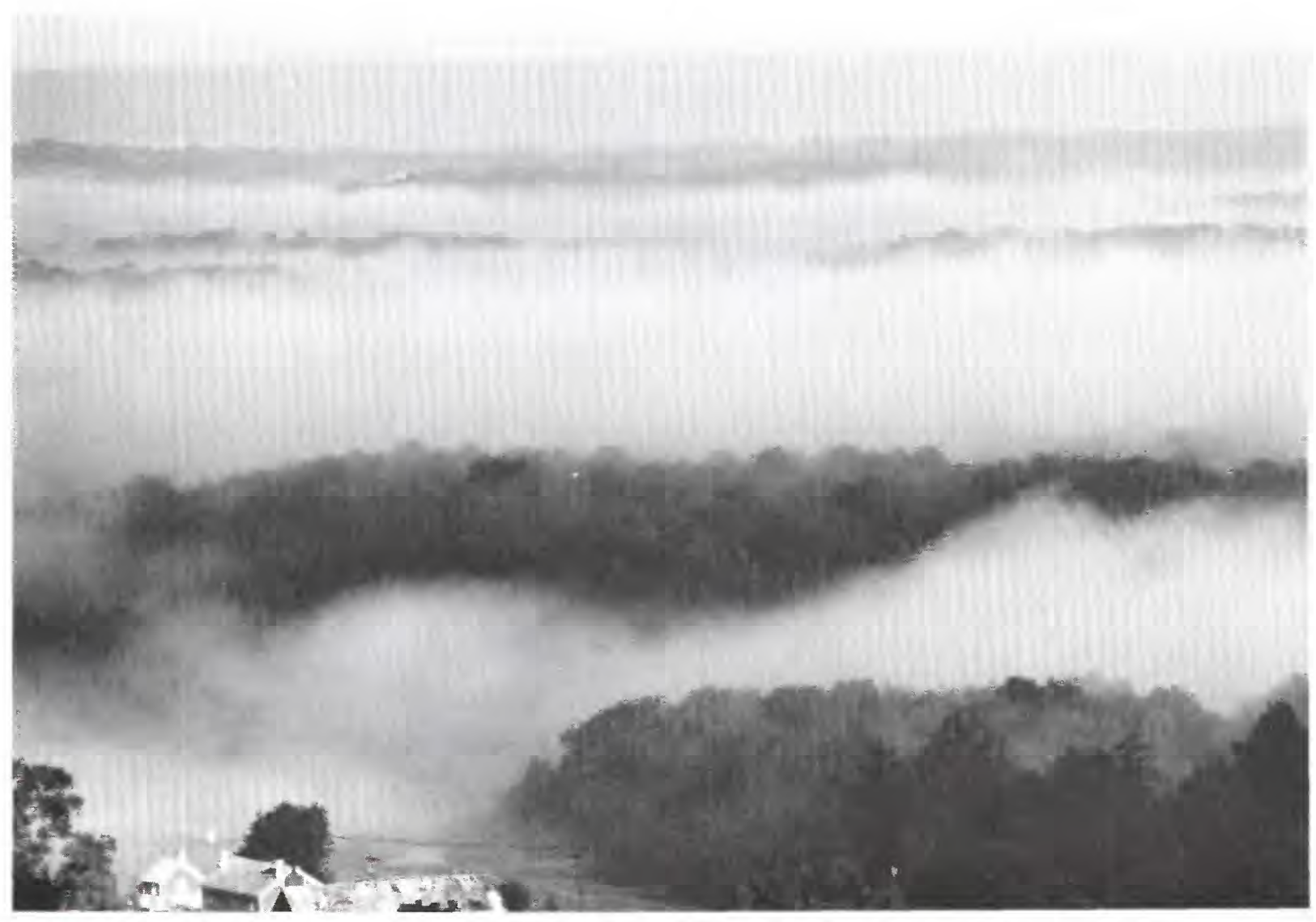

Figure 108.--Early morning fog passing through the Delaware River gap, resulting from the condensation of water in a cold air mass that descended into the valley during a clear, calm night. 


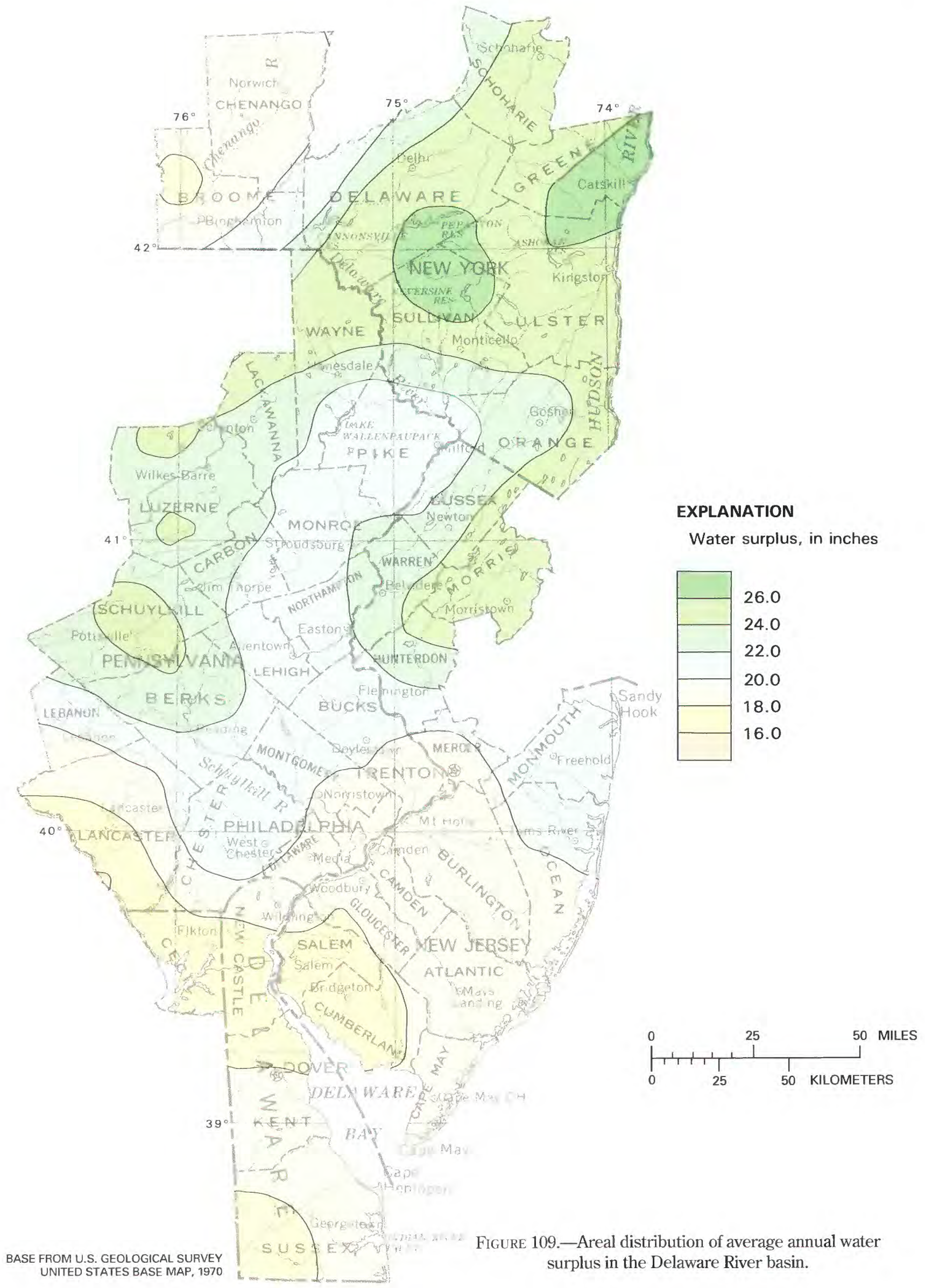



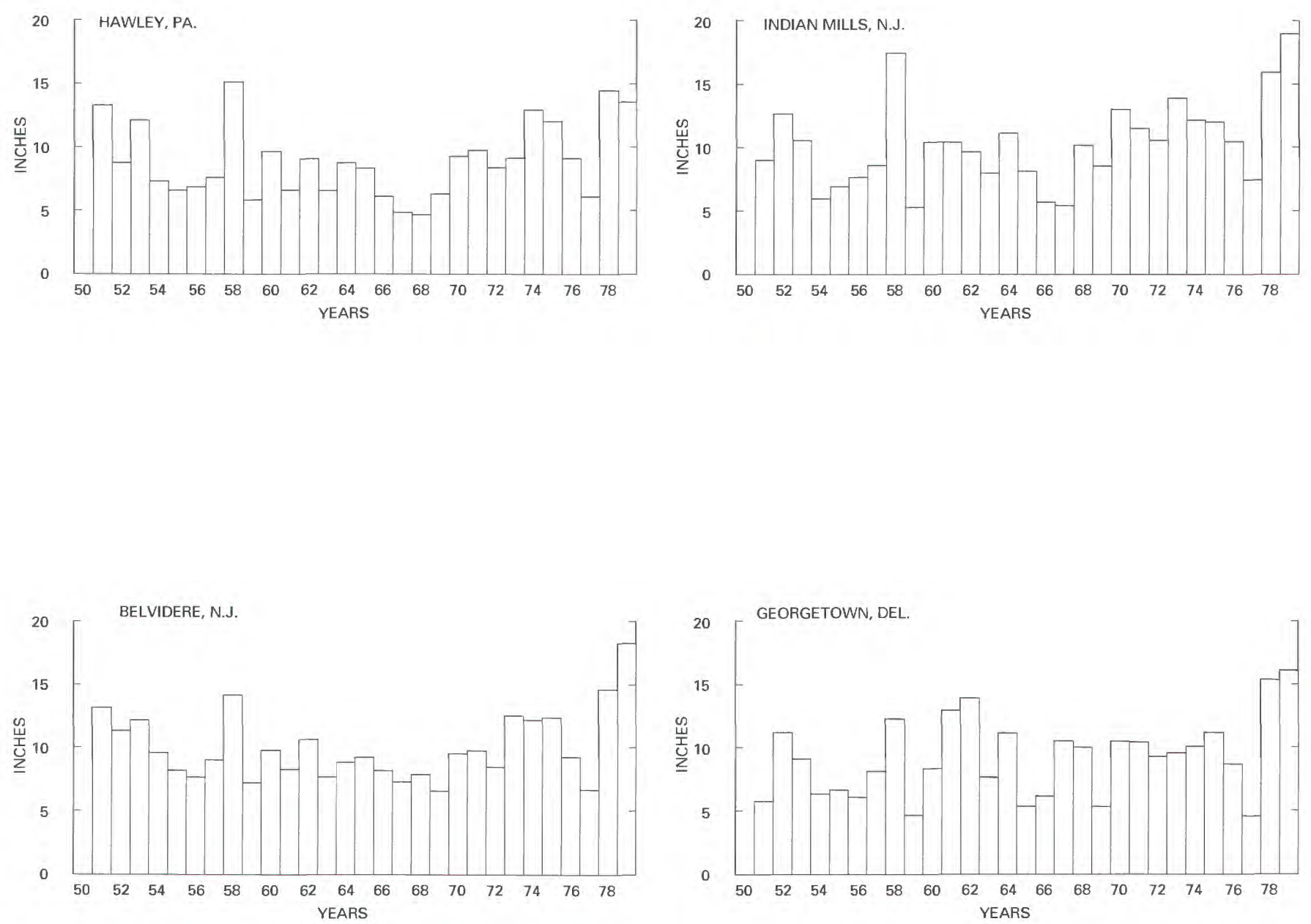

FIGURE 110.-Average water surplus during winter (December-February) at four stations in the Delaware River basin. 


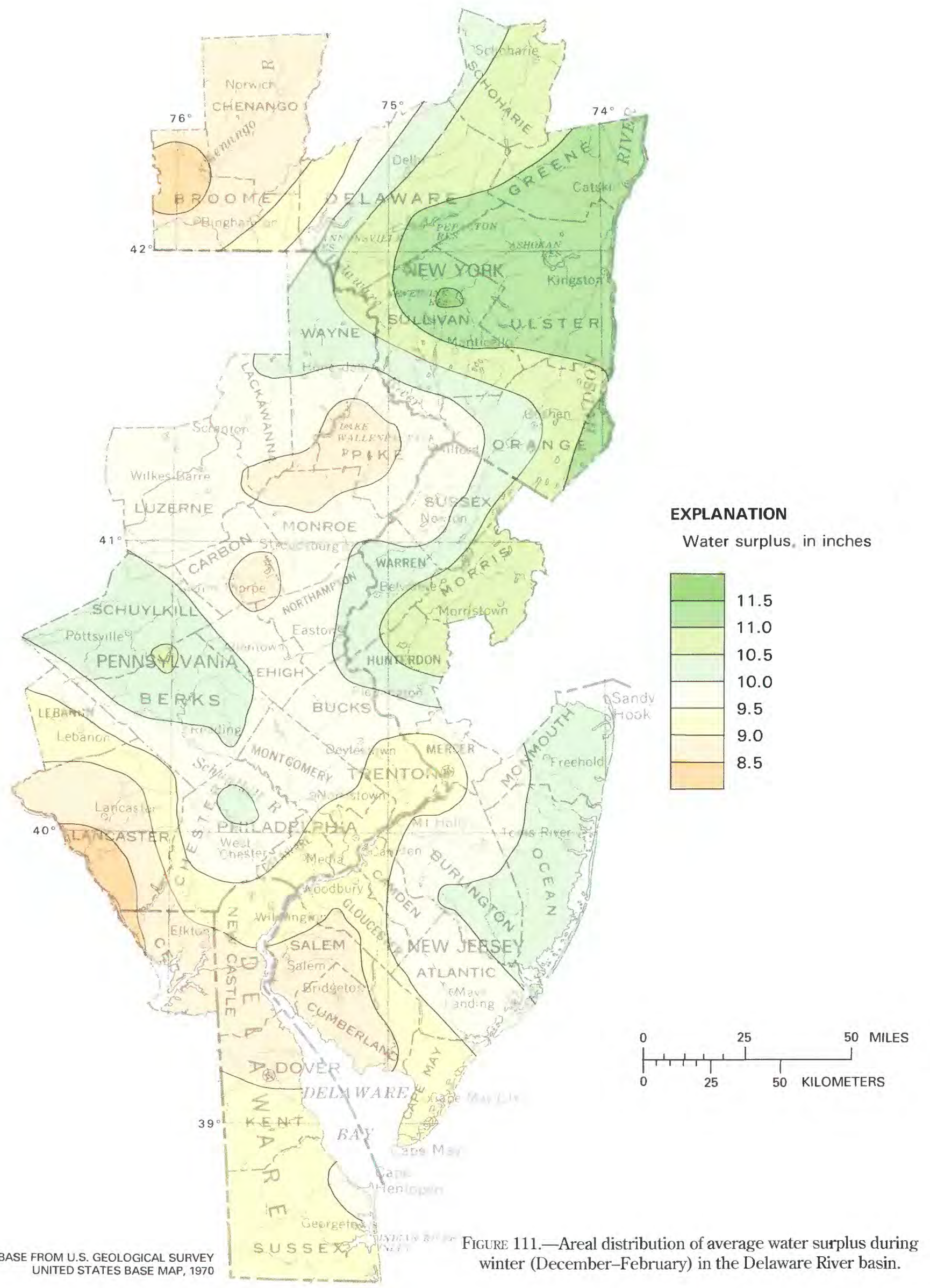



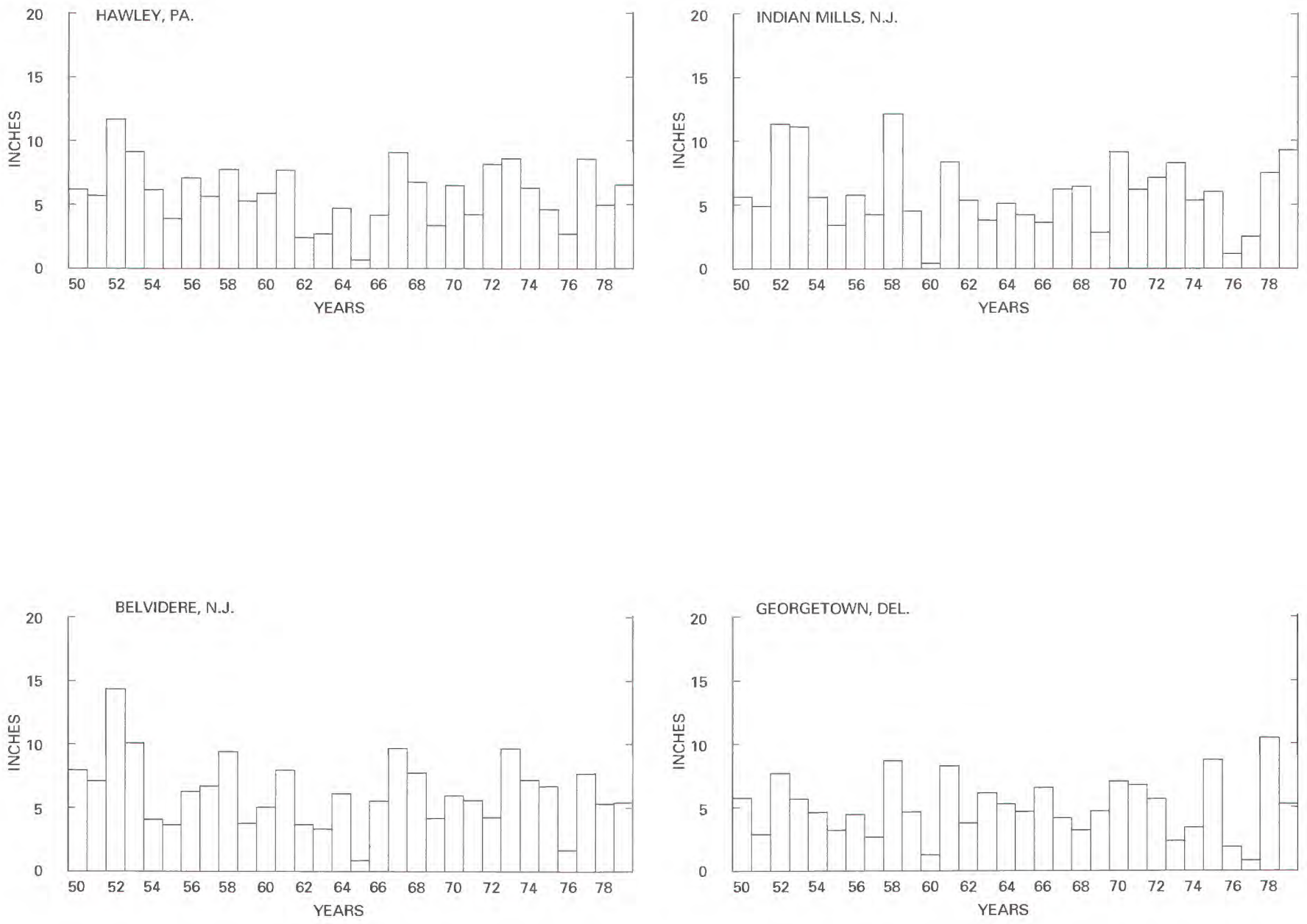

Figure 112.-Average water surplus during spring (March-May) at four stations in the Delaware River basin, $1950-79$. 


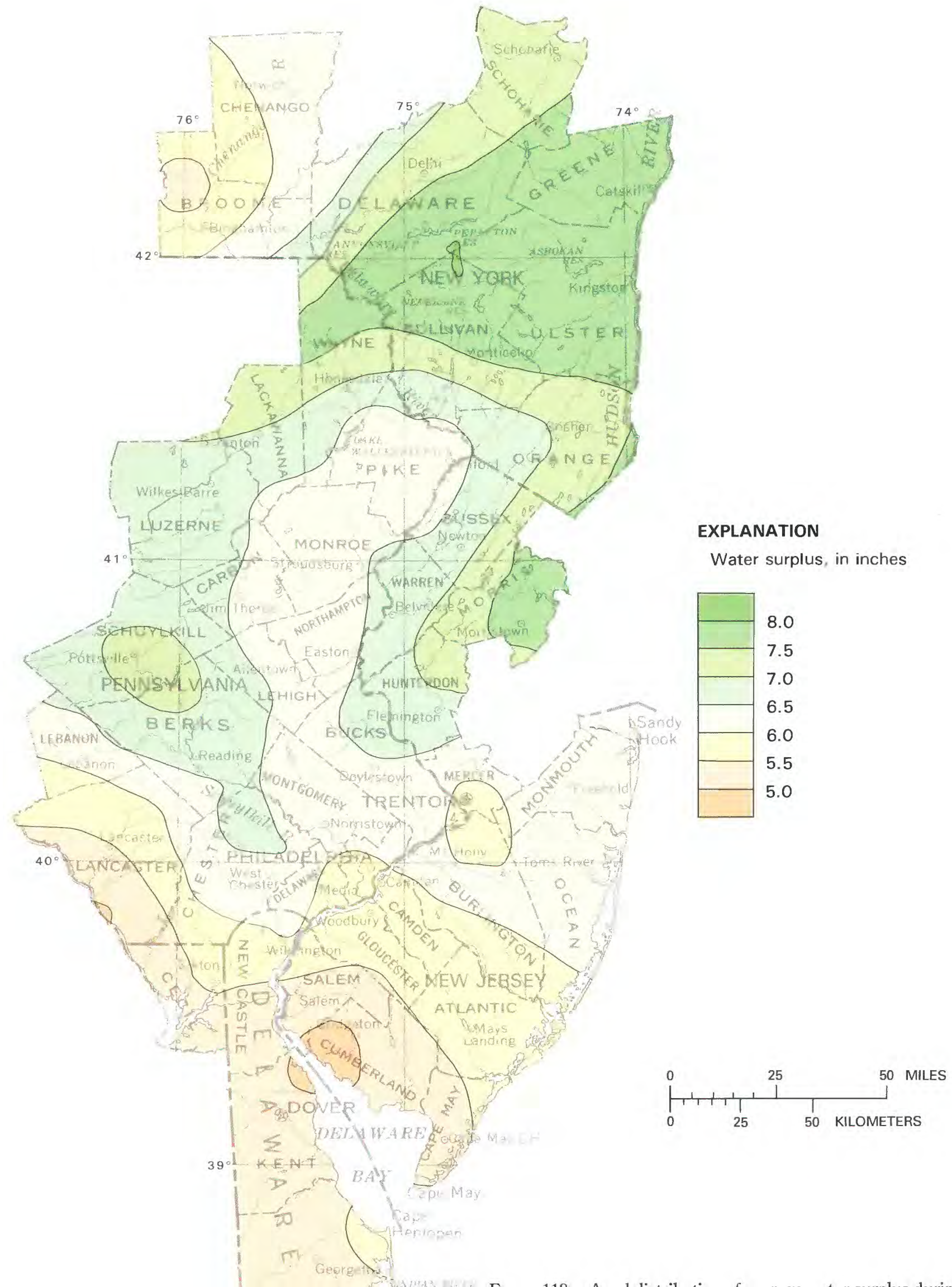
spring (March-May) in the Delaware River basin. 

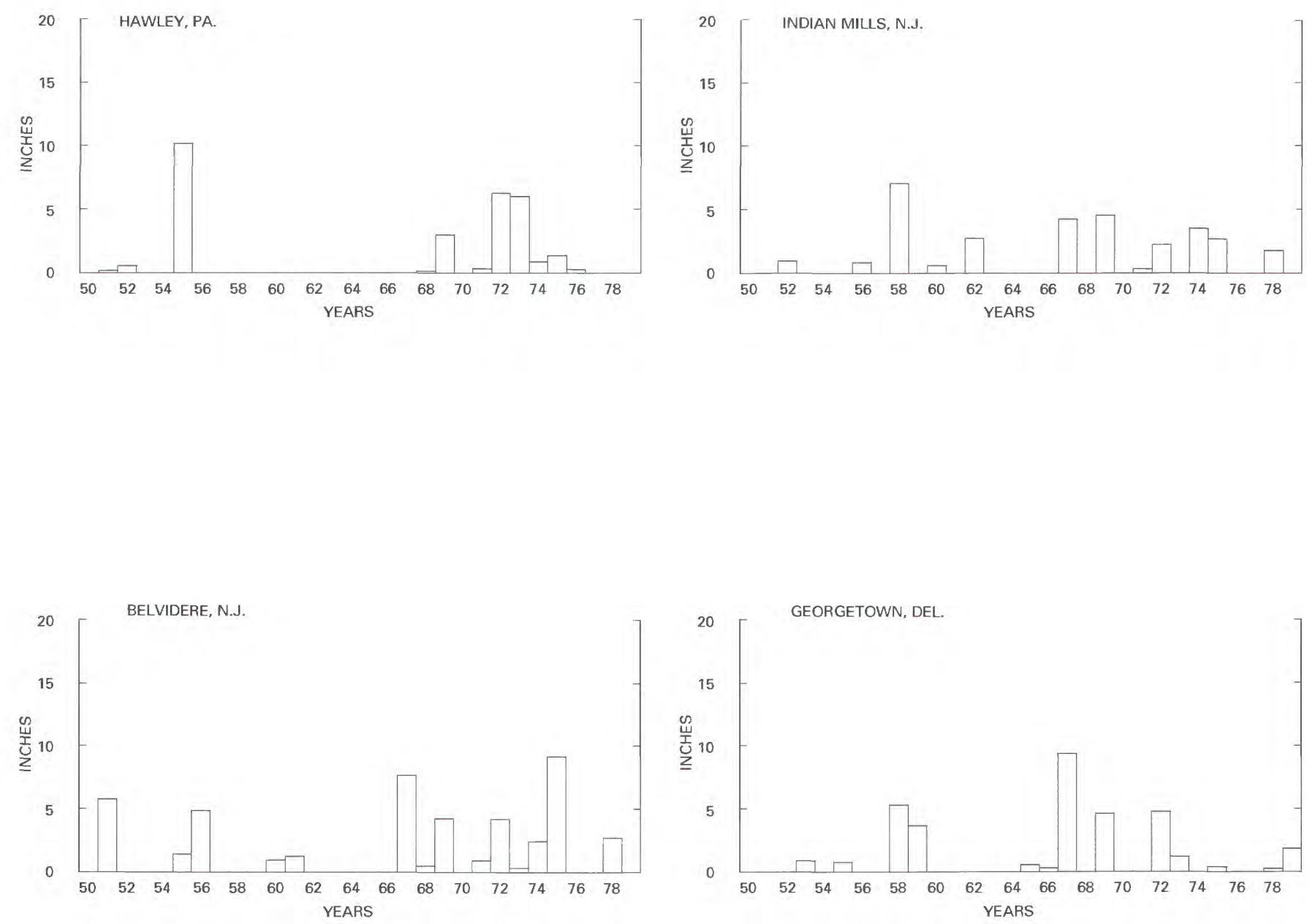

FIGTRE 114.-Average water surplus during summer (June-August) at four stations in the Delaware River basin 1950-79. 


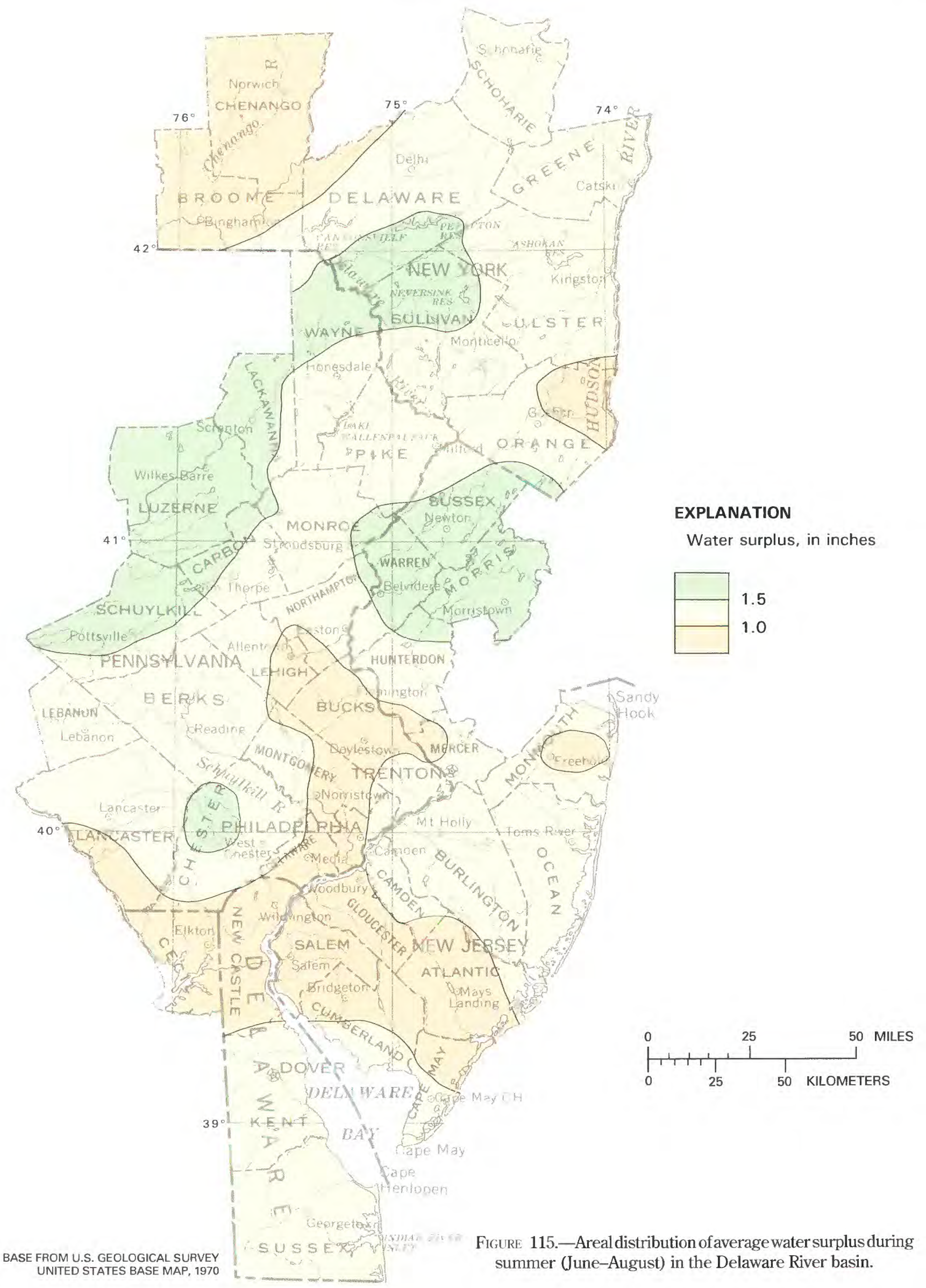



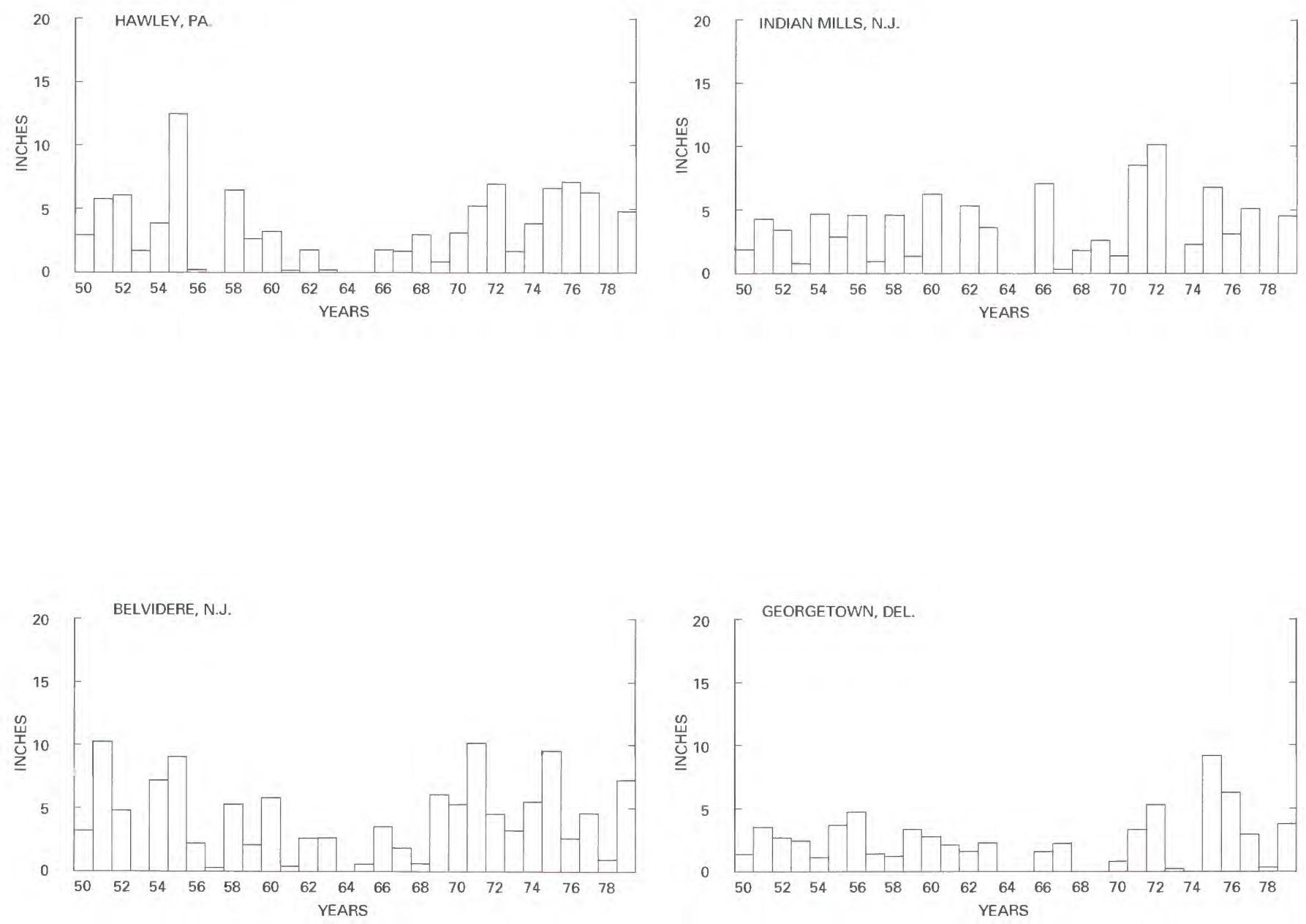

FIGIRE 116.-Average water surplus during fall (September-November) at four stations in the Delaware River basin, 1950-79. 


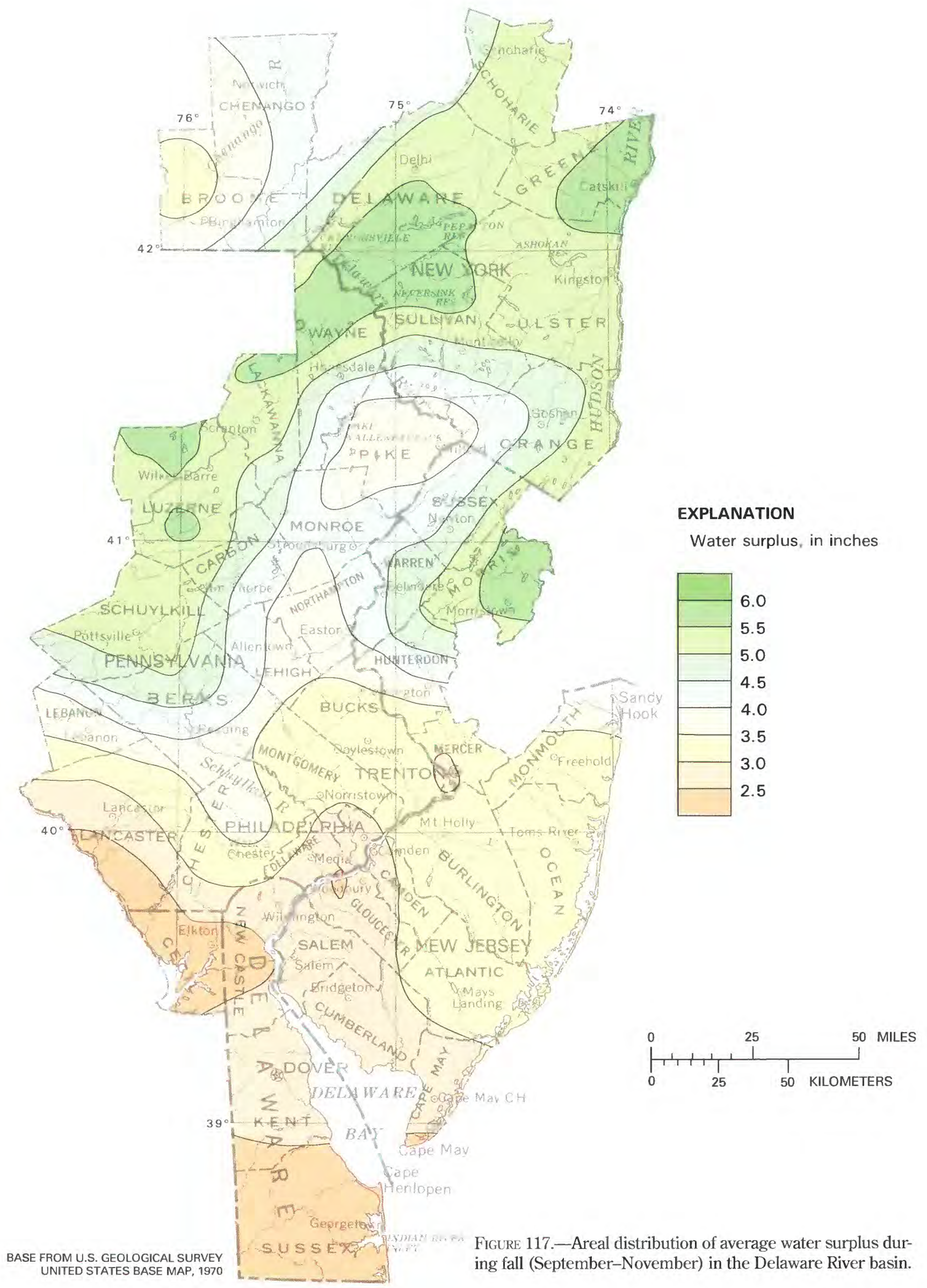




\section{WATER DEFICIT}

Periods of water deficit are concentrated during the summer months when potential evapotranspiration values are maximum (figs. 118 and 119). The map of average annual water deficit (fig. 119) indicates deficits of $4 \mathrm{in}$. in the southern part of the Delaware River basin and values of less than $2 \mathrm{in}$. in the north, where the annual climatic water demand is less.

The drought years in the early 1950's and the mid-1960's appear in the time series plots of annual water deficit (fig. 118).

\section{DROUGHT}

Drought may be defined in many ways. Perhaps the most commonly used definition relates drought to agricultural activities; drought occurs when precipitation is insufficient to provide for the water needs of plants. When considering drought within the Delaware
River basin, this definition must be expanded upon because agriculture is but one of the many activities that place a demand on the water supply of this highly populated region. A series of reservoirs have been constructed within the basin to store water surpluses that occur typically during the winter half of the year. These reservoirs serve to ensure water availability throughout the year for industrial and domestic purposes and for agricultural irrigation. Thus, winter precipitation is of critical importance to the water supply of the region, as is that of the summer growing season.

The Delaware River basin has been significantly affected by drought during three episodes since 1950 . The 1952-55 period was characterized by unusually high summer temperatures over the entire country with relatively low precipitation totals. Namias (1955) related this to the extension of the Bermuda subtropical high pressure system across the Southern United States. This resulted in anomalous easterly and northeasterly flow
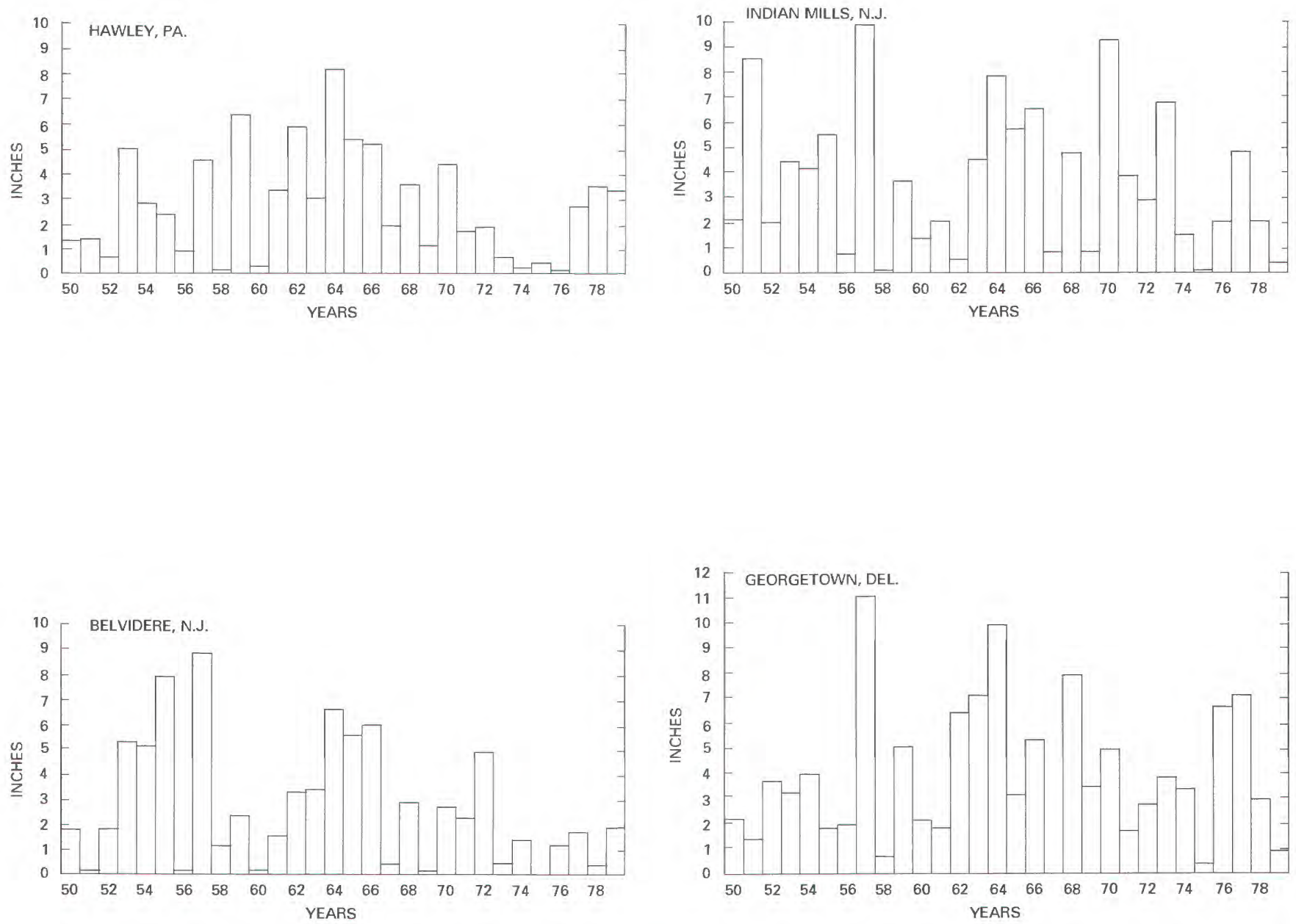

Figure 118. - Average annual water deficit at four stations in the Delaware River basin, 1950-79. 


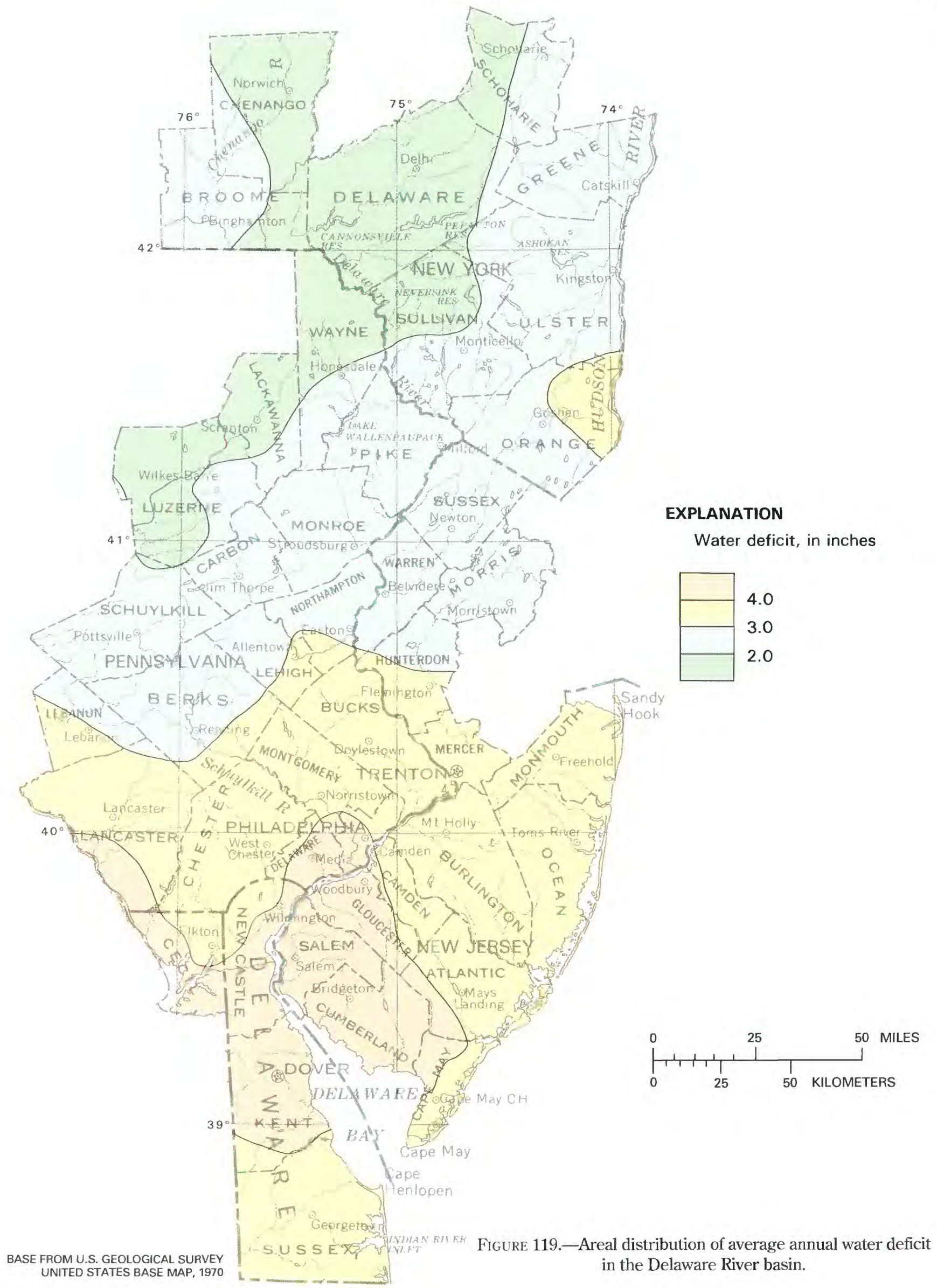


components in the Gulf of Mexico area, which inhibited the flow of moist gulf air into the Northeast. Figures $120 \mathrm{~A}$ and $120 \mathrm{~B}$ show the annual water deficits (Thornthwaite method) for the Delaware River basin for the years 1953 and 1954, respectively. These may be compared with the average annual water deficits shown in figure 119.

A drought that was much less extensive than that of the early 1950's was felt primarily in the Northeastern United States including the Delaware River basin. This drought began in the summer of 1961 , became severe in the fall of 1963, and lasted through the summer of 1965 (Andrews, 1966). Namias (1966) attributes the dry conditions in the Northeast during this period to an eastward displacement of the trough off the Atlantic Coast and an accompanying shift of the major storm tracks. Figure $120 C$ shows the annual water deficits for 1964 as a representative example of conditions associated with this drought period.

The third drought affecting the Delaware River basin since 1950 began to develop in May 1980, when the Northeast was downstream from a major ridge that extended from western Canada into the North-Central United States. This resulted in relatively low precipitation amounts for the month, particularly in the northern parts of the Delaware River basin (Taubensee, 1980a). During June and July, an amplified circulation developed having strong ridges at the 700-millibar level over the central Pacific, Central United States, and central Atlantic; troughs were situated near each coast. Subtropical highs extended over much of the southern part of the country. This marked the beginning of the heat wave and drought conditions that charcterized the summer of 1980 for most of the United States east of the Rockies (Livezey, 1980; Dickson, 1980). The full impact of the 1980 drought was felt within the Delaware River basin during August, when the 700-millibar high pressure center shifted eastward. The Northeast experienced high temperatures, and precipitation within the Delaware River basin was generally less than half of average amounts. Philadelphia's average temperature of $80^{\circ} \mathrm{F}$ for the month was the highest for August since 1900. Allentown's rainfall of $0.93 \mathrm{in}$. was the lowest for August since recordkeeping began in 1923 (Wagner, 1980). During September, anomalously high pressure remained in the southeastern part of the country, and drought conditions continued in the Delaware River basin, particularly in the northern parts (Taubensee, 1980b). Precipitation totals during October and November were closer to average values but still lower than normal (Dickson, 1981; Livezey, 1981). December conditions were devastating to the water supply situation of the Delaware River basin. Low precipitation amounts were the result of strong northwesterly flow that prevented gulf moisture from reaching the area. Much of the region received less than 25 percent of normal precipitation. Trenton, N.J., experienced the second driest December on record with a total precipitation of only $0.58 \mathrm{in}$. (Taubensee, 1981). Figure $120 \mathrm{D}$ shows the 1980 cumulative water deficit, as calculated by the Thornthwaite method described earlier, for selected stations in the Delaware River basin. 

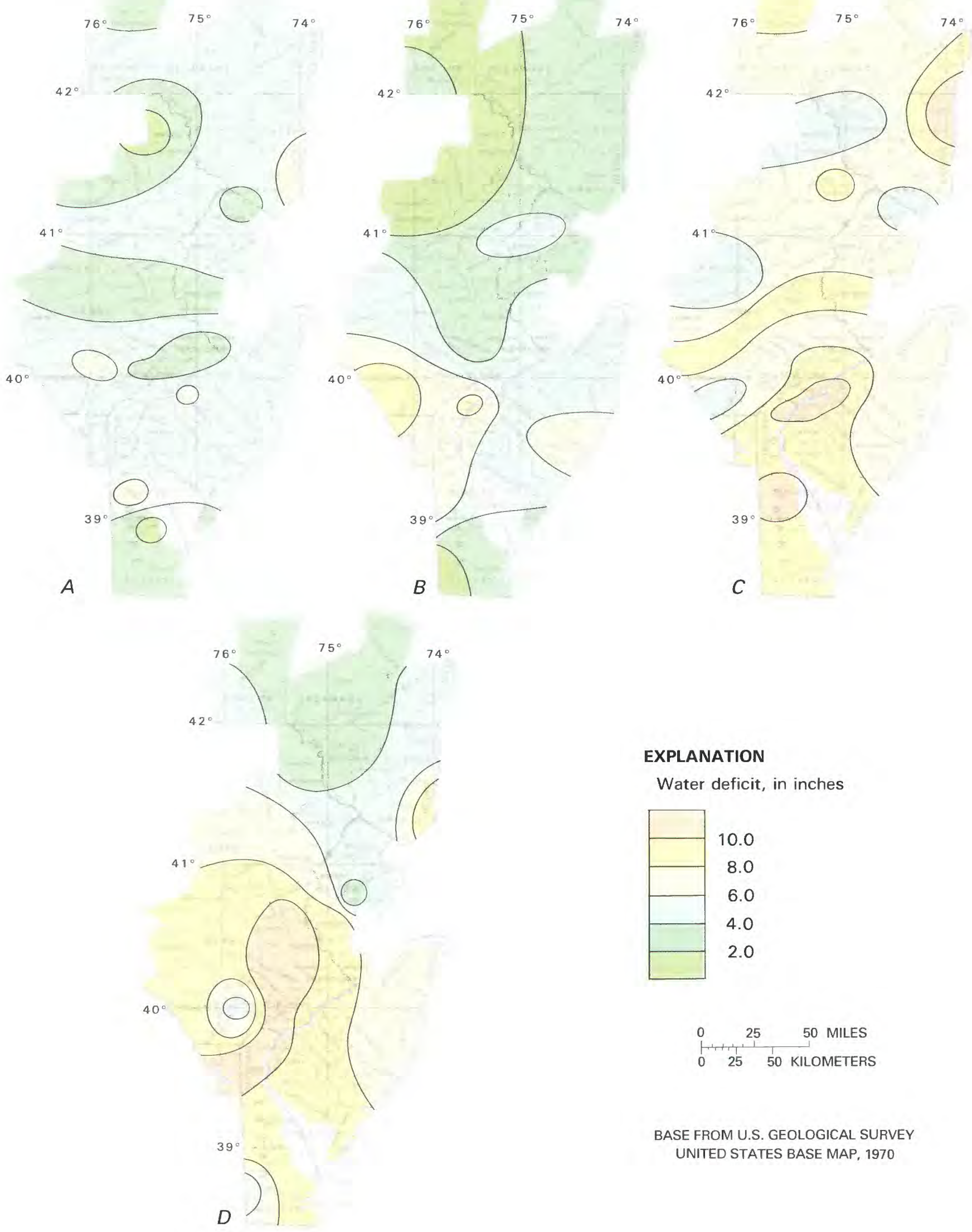

\section{EXPLANATION}

Water deficit, in inches

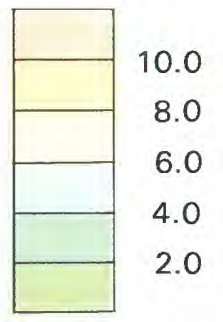

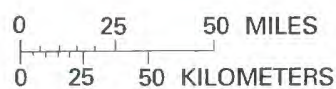

BASE FROM U.S. GEOLOGICAL SURVEY UNITED STATES BASE MAP, 1970

Figure 120.-Annual water deficits in the Delaware River basin during $A, 1953 ; B, 1954 ; C, 1964$; and $D, 1980$. 


\section{HURRICANES AND TROPICAL STORMS}

The Delaware River basin is not within the major North Atlantic hurricane belt. Storms of tropical origin have entered the area, but in most cases they have traveled parallel to the coast, either on land or on sea, and the full intensity of the storm has not been felt within the region. Nevertheless, considerable damage has been attributed to these tropical storms.

By convention, tropical cyclones having maximum wind speeds of at least $39 \mathrm{mph}$ but less than $74 \mathrm{mph}$ are known as tropical storms; those with winds of at least $74 \mathrm{mph}$ are hurricanes. On the average, four tropical cyclones per year reach the mainland United States; two of these, on the average, reach hurricane strength. These systems originate in tropical latitudes, often as easterly waves, move westward, and then recurve toward the north or northeast. The systems move at 10 to $20 \mathrm{mph}$ during formation and at speeds of $40 \mathrm{mph}$ or more when fully developed (Baldwin, 1973; Dunn and Miller, 1960).

Dunn (1951) has recognized four major stages in the life of a typical hurricane. These are (1) the formative stage, which includes the development of the storm to the point where winds of hurricane strength occur; (2) the stage of immaturity, when the cyclone remains compact while the pressure gradient increases; (3) the mature stage, during which the cyclone expands in area; and (4) the decaying stage marked by landfall and dissipation or by northward movement and acquisition of extratropical characteristics.

In an average-sized hurricane, the diameter of hurricane-force winds is $100 \mathrm{mi}$; winds of gale force cover a $350-400 \mathrm{mi}$ diameter, but great variability exists. The eye of the hurricane, which is an area of light winds, clear sky, and relatively warm temperatures, averages $14 \mathrm{mi}$ in diameter but has been known to range from 4 to $25 \mathrm{mi}$ across. Maximum wind speeds recorded at land stations during hurricanes exceeded $150 \mathrm{mph}$ (Dunn and Miller, 1960).

Destruction associated with tropical cyclones occurs as a result of strong winds, storm tides, and heavy rainfall. Heavy rains and accompanying flooding have been the primary causes of tropical cyclone-related damage within the Delaware River basin.

Figure 121 shows the paths of hurricanes and tropical storms of the 1950-79 period that have affected parts of the Delaware River basin. Brief descriptions of the individual systems follow.

Hurricane Carol (August 26-31, 1954) passed offshore in the Delaware River basin latitudes but did major damage in the Carolinas and in New England. The Delaware River basin was affected by heavy precipitation and strong winds but escaped the major destruction experienced by the areas to the north and south (Winston, 1954; Davis, 1954).
Hurricane Edna (September 6-11, 1954) followed a path similar to that of Carol. The area of strong winds and heavy rainfall extended into the Delaware River basin, but again the area escaped the major damage of the storm (Malkin and Holzworth, 1954; Davis, 1954).

Hurricane Hazel (October 5-16, 1954) reached the South Carolina coast on October 15 and maintained unusually strong winds as it moved northward. The path was west of the Delaware River basin, but the entire region suffered extensive damage as a result of strong winds and heavy rains (Krueger, 1954; Davis, 1954).

Hurricane Connie (August 3-13, 1955) reached the North Carolina coast on August 12 and moved toward the Washington, D.C., area and into Pennsylvania. Dry weather preceded Connie, so the heavy rainfall associated with the storm did little damage and served to replenish the soil-moisture supply in affected areas (Gentry, 1956).

Hurricane Diane (August 10-19, 1955) followed closely on the heels of Connie, reaching the North Carolina coast August 17. It then moved northward and eastward, affecting areas that had recently experienced the passage of Hurricane Connie. Namias and Dunn (1955) attribute the unusual occurrence of "twin" hurricanes to an abnormally contracted circumpolar vortex. Although Diane was not a particularly intense storm, the torrential rains that fell from eastern Maryland to southeastern New England resulted in major flooding of many streams, including the Delaware River and its tributaries. Resulting property damage earned Diane the nickname "the Billion Dollar Hurricane" (Gentry, 1956; Dunn and Miller, 1960).

Tropical Storm Brenda (July 28-31, 1960) moved into western Florida on July 28 and traveled along the Atlantic Coast. The major effect of the storm in the Delaware River basin was heavy rain (Moore, 1961).

Hurricane Donna (August 29-September 13, 1960) reached Florida on September 10 and moved northward along the Atlantic Coast. The storm was associated with gale-force wind extending inland, heavy precipitation, and extensive property damage (McGuire, 1960; Tisdale, 1960).

Tropical Storm Doria (August 20-29, 1971) reached the North Carolina coast on August 27 and moved along the Atlantic Coast to New England. Flooding was the major cause of damage (Pardue and Hope, 1972).

Hurricane Agnes (June 14-22, 1972) entered the Florida panhandle on June 19. It intensified when it merged with a major extratropical storm. On June 21 a secondary low developed west of the original center, and two lows moved northward. The system intensified to reach tropical storm status again over North Carolina. The lowest pressure recorded for Agnes was 977 millibars just off the New Jersey coast. Precipitation totals for the storm were in the 10 to 14 in. range in 


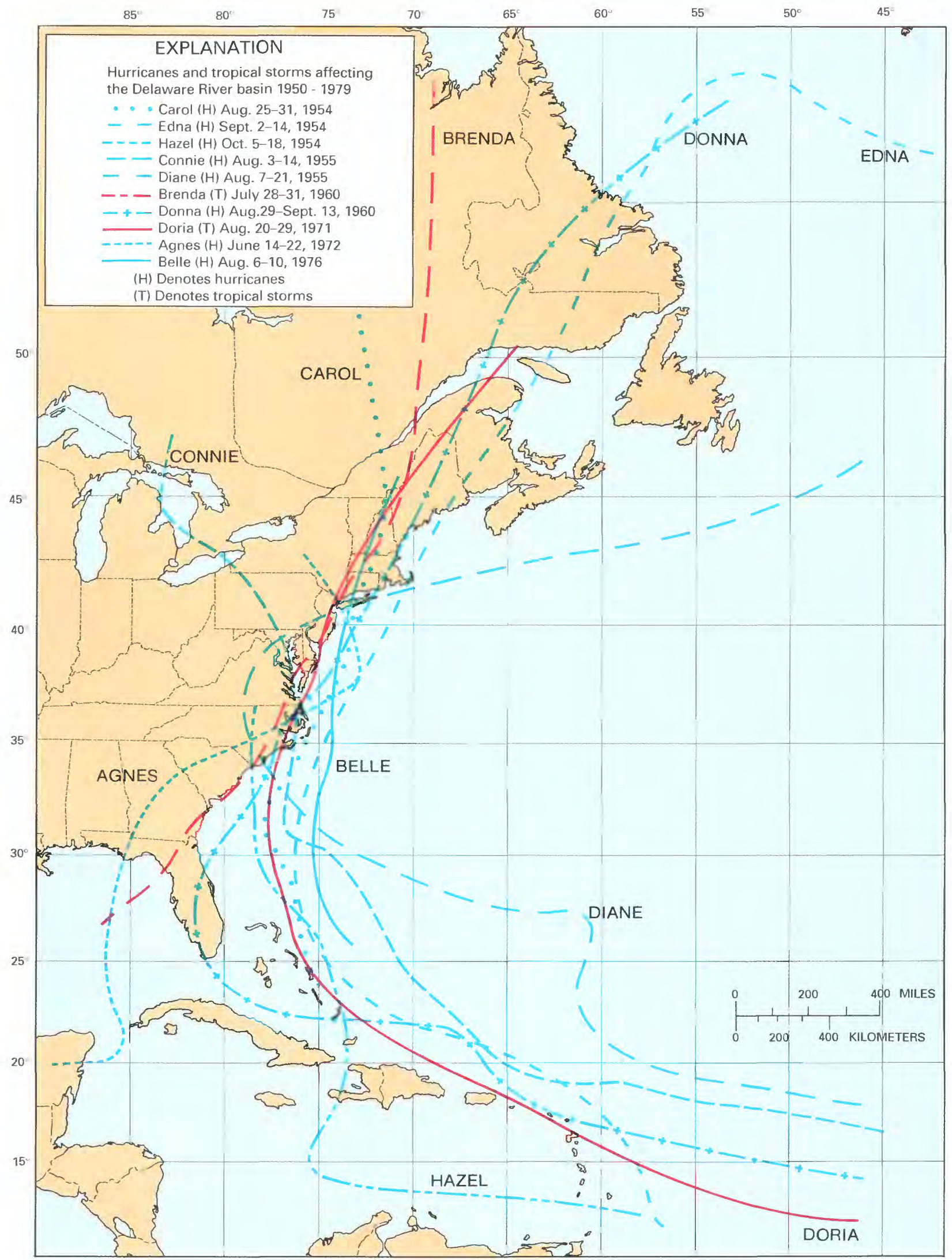

FIGURE 121.-Path of hurricanes and tropical storms that affected the Delaware River basin, 1950-79. 
eastern Pennsylvania. These rains fell on saturated soil, so that most of the damage of the storm was due to river flooding. Agnes was one of the largest June hurricanes of record, with a circulation diameter of 1,000 nautical miles. It was also the most costly United States storm with respect to dollar damages (Simpson and Hebert, 1973).

Hurricane Belle (August 6-10, 1976) moved over water parallel to the Atlantic Coast until making landfall on Long Island on August 10. The storm rainfall within the Delaware River basin was generally less than 2 in., and most damage was related to strong winds (Lawrence, 1977).

\section{SELECTED REFERENCES}

Andrews, J.F., 1966, The circulation and weather of 1965: Weatherwise, v. 19 , p. $5-11,23$.

1968, The weather and circulation of August 1968Sharp contrasts in temperature and an unusually strong summer index cycle: Monthly Weather Review, v. 96, p. 826-832. 1969, The weather and circulation of July 1969A predominantly wet month, cool in the North and warm in the South: Monthly Weather Review, v. 97, p. 735-738.

Baldwin, J.L., 1973, Climates of the United States: Washington, D.C., U.S. Government Printing Office, 113 p.

Brinkmann, W.A.R., 1976, Surface temperature trend for the Northern Hemisphere-Updated: Quaternary Research, v 6, p. 355-358. 1979, Associations between temperature trends: Annals, Association of American Geographers, v. 69, p. 250-261.

Bryson, R.A., and Murray, T.J., 1977, Climates of hunger: Mankind and the world's changing weather: Madison, University of Wisconsin Press, $171 \mathrm{p}$.

Davis, W.R., 1954, Hurricanes of 1954: Monthly Weather Review, v. 82 , p. $370-373$.

Dickson, R.R., 1964, The weather and circulation of June 1964-A reversal of a long-standing trend over the Pacific: Monthly Weather Review, v. 92, p. 428-432.

1965, The weather and circulation of November 1964Contrasting weather regimes related to long-wave progression: Monthly Weather Review, v. 93, p. 123-126.

1966, The weather and circulation of December 1965Inciuding a discussion of the record dry year in the Northeast: Monthly Weather Review, v. 94, p. 192-197.

1973, Weather and circulation of November 1972-Another cold, wet month: Monthly Weather Review, v. 101, p . 182-186. 1977, Weather and circulation of November 1976-Record cold over the South and Midwest for the second consecutive month: Monthly weather review, v. 105, p. 239-244.

1980, Weather and circulation of June 1980-Inception of a heat wave and drought over the central and south Great Plains: Monthly Weather Review, v. 108, p. 1,469-1,474.

1981, Weather and circulation of October 1980-A decisive end to the heat wave: Monthly Weather Review, v. 109, p. 205-211.

Dunn, C.R., 1960, The weather and circulation of March 1960-A cold, snowy month: Monthly Weather Review, v. 88, p. 112-120.

Dunn, G.E., 1951, Tropical cyclones, in Compendium of meteorology: Boston, Mass., American Meteorological Society, p. 887-901.

Dunn, G.E., and Miller, B.I., 1960, Atlantic hurricanes: Baton Rouge, Louisiana State University Press, 326 p.
Gentry, R.C., 1956, The 1955 hurricane season: Weatherwise, v. 9, p. 11-13, 29-31.

Green, R.A., 1964, The weather and circulation of October 1963-Abnormal warmth and severe drought in the United States and two unusual hurricanes offshore: Monthly Weather Review, v. 92 , p. $37-42$.

Harkness, W.E., Lins, H.F., and Alley, W.M., 1986, Drought in the Delaware River basin, 1984-85, in National Water Summary 1985-Hydrologic Events and Surface-Water Resources, U.S. Geological Survey Water-Supply Paper 2300, p. 29-34.

Harmon, J.R., 1971, Tropospheric waves, jet streams, and United States weather patterns: Washington, D.C., Association of American Geographers, $37 \mathrm{p}$.

Krueger, A.F., 1954, The weather and circulation of October 1954-Including a discussion of Hurricane Hazel in relation to the large-scale circulation: Monthly Weather Review, v. 82, p. 296-300.

Lawrence, M.B., 1977, Atlantic hurricane season of 1976: Monthly Weather Review, v. 105 , p. $497-507$.

Livezey, R.E., 1980, Weather and circulation of July 1980-Climax of a historic heat wave and drought over the United States: Monthly Weather Review, v. 108 , p. 1,708-1,716.

1981, Weather and circulation of November 1980-A late heat wave and hurricane and early snow: Monthly Weather Review, v. 109 , p. 396-402.

Malkin, W., and Holzworth, G.C., 1954, Hurricane Edna, 1954: Monthly Weather Review, v. 82, p. 267-279.

Mather, J.R., 1978, The climatic water budget in environmental analysis: Lexington, Mass., Lexington Books, 239 p.

McGuire, J.K., 1960, Hurricane Donna in the Northeast: Weatherwise, v. 13, p. $215-217$.

Moore, P.L., 1961, The hurricane season of 1960: Weatherwise, v. 14, p. $18-23$.

Namias, J., 1955, Some meteorological aspects of drought-With special reference to the summers of 1952-54 over the United States: Monthly Weather Review, v. 83, p. 199-205.

1966, Nature and possible causes of the northeastern United States drought during 1962-65: Monthly Weather Review, v. 94 , p. $543-554$.

1974, Longevity of a coupled air-sea-continent system: Monthly Weather Review, v. 102, p. 638-648.

Namias, J., and Dunn, C.R., 1955, The weather and circulation of August 1955-Including the climatological background for Hurricanes Connie and Diane: Monthly Weather Review, v. 83, p. $163-170$.

Neumann, C.J., Cry, G.W., Caso, E.L., and Jarvinen, B.R., 1978, Tropical cyclones of the North Atlantic Ocean, 1871-1977: Washington, D.C., U.S. Government Printing Office.

Pardue, L.G., and Hope, J.R., 1972, The hurricane season of 1971: Weatherwise, v. 25, p. 11-19.

Reitan, C.H., 1974, A climatic model of solar radiation and temperature change: Quaternary Research, v. 4, p. 25-38.

Simpson, R.H., and Hebert, P.J., 1973, Atlantic hurricane season of 1972: Monthly Weather Review, v. 101, p. 323-333.

Stark, L.P., 1967, The weather and circulation of May 1967-Strong blocking and record cold in the East: Monthly Weather Review, v. 95 , p. $587-592$.

Taubensee, R.E., 1970, The weather and circulation of September 1970-Warm in the East and cool in the West with heavy precipitation in many central areas: Monthly Weather Review, v. 98, p. 939-943.

1974, Weather and circulation of December 1973-A wet month over much of the country: Monthly Weather Review, v. 102 , p. $262-267$. 
- 1977, Weather and circulation of March 1977-Record and near-record precipitation eases drought in parts of the Great Plains and Midwest: Monthly Weather Review, v. 105, p. 793-799.

$1980 \mathrm{a}$, Weather and circulation of May 1980-Record heavy precipitation in the northern Rocky Mountains while drought affected the northern Great Plains: Monthly Weather Review, v. 108 , p. 1,270-1,277.

$1980 \mathrm{~b}$, Weather and circulation of September 1980-Heat wave ends late in the month: Monthly Weather Review, v. 108, p. $2,100-2,106$.

1981, Weather and circulation of December 1980-A generally dry month with record warmth in the West: Monthly Weather Review, v. 109, p. 676-682.

Thornthwaite, C.W., 1948, An approach toward a rational classification of climate: Geographical Review, v. 38, p. 55-94.

Tisdale, C.F., 1960, The weather and circulation of September 1960-Including a discussion of tropical storm activity: Monthly Weather Review, v. 88, p. 353-361.

U.S. Council on Environmental Quality, 1975, The Delaware River basin: An environmental assessment of three centuries of change: Washington, D.C., U.S. Government Printing Office, 87 p.

U.S. National Oceanic and Atmospheric Administration, 1950-1980, Climatological data, annual and monthly summaries for Mary- land and Delaware, New Jersey, Pennsylvania, and New York: Washington, D.C., U.S. Government Printing Office.

1960-1979, Climatological data, national summary, annual and monthly summaries: Washington, D.C., U.S. Government Printing Office.

1977, Daily weather maps, weekly series, January $17-23,1977$ : Washington, D.C., U.S. Government Printing Office.

Wagner, A.J., 1977a, Weather and circulation of January 1977-The coldest month on record in the Ohio Valley: Monthly Weather Review, v. 105 , p. $553-560$.

$1977 \mathrm{~b}$, Weather and circulation of April 1977-Generally mild and wet but continued drought in the West: Monthly Weather Review, v. 105, p. $933-939$.

1978, Weather and circulation of January 1978-Cold with record snowfall in the Midwest and Northeast, mild and wet in the West: Monthly Weather Review, v. 106, p. 579-585.

1980, Weather and circulation of August 1980-Eastward spread of heat wave and drought: Monthly Weather Review, v. 108 , p. $1,924-1,932$.

Winston, J.S., 1954, The weather and circulation of August 1954-Including a discussion of Hurricane Carol in relation to the planetary wave pattern: Monthly Weather Review, v. 82, p. $228-236$. 
- 


\section{SELECTED SERIES OF U.S. GEOLOGICAL SURVEY PUBLICATIONS}

\section{Periodicals}

Earthquakes \& Volcanoes (issued bimonthly).

Preliminary Determination of Epicenters (issued monthly).

\section{Technical Books and Reports}

Professional Papers are mainly comprehensive scientific reports of wide and lasting interest and importance to professional scientists and engineers. Included are reports on the results of resource studies and of topographic, hydrologic, and geologic investigations. They also include collections of related papers addressing different aspects of a single scientific topic.

Bulletins contain significant data and interpretations that are of lasting scientific interest but are generally more limited in scope or geographic coverage than Professional Papers. They include the results of resource studies and of geologic and topographic investigations, as well as collections of short papers related to a specific topic.

Water-Supply Papers are comprehensive reports that present significant interpretive results of hydrologic investigations of wide interest to professional geologists, hydrologists, and engineers. The series covers investigations in all phases of hydrology, including hydrogeology, availability of water, quality of water, and use of water.

Circulars present administrative information or important scientific information of wide popular interest in a format designed for distribution at no cost to the public. Information is usually of short-term interest.

Water-Resources Investigations Reports are papers of an interpretive nature made available to the public outside the formal USGS publications series. Copies are reproduced on request unlike formal USGS publications, and they are also available for public inspection at depositories indicated in USGS catalogs.

Open-File Reports include unpublished manuscript reports, maps, and other material that are made available for public consultation at depositories. They are a nonpermanent form of publication that may be cited in other publications as sources of information.

\section{Maps}

Geologic Quadrangle Maps are multicolor geologic maps on topographic bases in 7.5- or 15-minute quadrangle formats (scales mainly $1: 24,000$ or 1:62,500) showing bedrock, surficial, or engineering geology. Maps generally include brief texts; some maps include structure and columnar sections only.

Geophysical Investigations Maps are on topographic or planimetric bases at various scales; they show results of surveys using geophysical techniques, such as gravity, magnetic, seismic, or radioactivity, which reflect subsurface structures that are of economic or geologic significance. Many maps include correlations with the geology.

Miscellaneous Investigations Series Maps are on planimetric or topographic bases of regular and irregular areas at various scales; they present a wide variety of format and subject matter. The series also includes 7.5-minute quadrangle photogeologic maps on planimetric bases that show geology as interpreted from aerial photographs. Series also includes maps of Mars and the Moon.
Coal Investigations Maps are geologic maps on topographic or planimetric bases at various scales showing bedrock or surficial geology, stratigraphy, and structural relations in certain coal-resource areas.

Oil and Gas Investigations Charts show stratigraphic information for certain oil and gas fields and other areas having petroleum potential.

Miscellaneous Field Studies Maps are multicolor or blackand-white maps on topographic or planimetric bases on quadrangle or irregular areas at various scales. Pre-1971 maps show bedrock geology in relation to specific mining or mineral-deposit problems; post-1971 maps are primarily black-and-white maps on various subjects such as environmental studies or wilderness mineral investigations.

Hydrologic Investigations Atlases are multicolored or blackand-white maps on topographic or planimetric bases presenting a wide range of geohydrologic data of both regular and irregular areas; principal scale is $1: 24,000$, and regional studies are at 1:250,000 scale or smaller.

\section{Catalogs}

Permanent catalogs, as well as some others, giving comprehensive listings of U.S. Geological Survey publications are available under the conditions indicated below from the U.S. Geological Survey, Books and Open-File Reports Section, Federal Center, Box 25425, Denver. CO 80225. (See latest Price and Availability List.)

"Publications of the Geological Survey, 1879-1961" may be purchased by mail and over the counter in paperback book form and as a set of microfiche.

"Publications of the Geological Survey, 1962-1970" may be purchased by mail and over the counter in paperback book form and as a set of microfiche.

"Publications of the U.S. Geological Survey, 1971-1981" may be purchased by mail and over the counter in paperback book form (two volumes, publications listing and index) and as a set of microfiche.

Supplements for 1982, 1983,1984, 1985, 1986, and for subsequent years since the last permanent catalog may be purchased by mail and over the counter in paperback book form.

State catalogs, "List of U.S. Geological Survey Geologic and Water-Supply Reports and Maps For (State)," may be purchased by mail and over the counter in paperback booklet form only.

"Price and Availability List of U.S. Geological Survey Publications," issued annually, is available free of charge in paperback booklet form only.

Selected copies of a monthly catalog "New Publications of the U.S. Geological Survey" are available free of charge by mail or may be obtained over the counter in paperback booklet form only. Those wishing a free subscription to the monthly catalog "New Publications of the U.S. Geological Survey" should write to the U.S. Geological Survey, 582 National Center, Reston, VA 22092.

Note. - Prices of Government publications listed in older catalogs, announcements, and publications may be incorrect. Therefore, the prices charged may differ from the prices in catalogs, announcements, and publications. 